\title{
TREES OF LAOS AND VIETNAM: A FIELD GUIDE TO 100 ECONOMICALLY OR ECOLOGICALLY IMPORTANT SPECIES
}

\author{
HOANG VAN SAM ${ }^{1}$, KHAMSENG NANTHAVONG ${ }^{2}$ \& P.J.A. KESSLER ${ }^{3}$
}

\begin{abstract}
SUMMARY
This field guide to 100 economically or ecologically important tree species from Laos and Vietnam enables the user to identify the included taxa with user-friendly keys. It includes scientific names, botanical descriptions of families, genera, and species. Specific information on distribution, habitat, ecology, and uses has been compiled. All specimens examined have been listed.
\end{abstract}

Key words: Flora of Laos and Vietnam, field guide, tree-identification, tree flora, Indochina.

\section{INTRODUCTION}

Laos and Vietnam's forests are one of the countries' richest natural resources, supporting a huge diversity of plant and animal life, and providing forest products to support local livelihoods. In recent years forest cover in the tropics has decreased drastically and Laos and Vietnam are among the few South East Asian countries where still a substantial part of the land is covered by often unexplored, practically unknown original vegetation. Except 'Flore du Laos, du Cambodge et du Vietnam' and its predecessors there is no publication which enables us to identify plants with an easy to use key. Almost all other publications are descriptive but without any means to identify plants except comparing either descriptions or photographs. Our manual aims at assisting foresters and botanists and their students with user-friendly keys in the identification of some major components of the forests. We hope that our contribution will stimulate further studies of the flora.

\section{SCOPE OF THE FIELD GUIDE}

The intended scope of the manual is a Flora containing 100 tree species belonging to 83 genera and 40 families from Vietnam and Laos, important either economically or ecologically, and the means to identify them by field as well as herbarium characters. This manual contains all the information which is needed for identification, including

1) Vietnam Forestry University, Faculty of Forest Resources \& Environment Management, Xuan Mai, Chuong My, Ha Tay, Vietnam.

2) National University of Laos, Faculty of Forestry, Department of Forest Management, P.O. Box 7322, Vientiane, Lao PDR.

3) Nationaal Herbarium Nederland, Universiteit Leiden branch, P.O. Box 9514, 2300 RA Leiden, The Netherlands; e-mail: Kessler@nhn.leidenuniv.nl. 
full scientific names, synonyms, literature, vernacular names, botanical descriptions, distribution, habitat \& ecology, uses, and specimens examined. Keys to the families, genera, and species are given.

\section{FORMAT OF DESCRIPTIONS}

- Families, genera, and species are treated in alphabetical order within the two major groups 'Gymnospermae' and 'Angiospermae'.

- If a family contains more than 1 genus, a key to the genera is given. If a genus has more than one species, a key to the species is given.

- Scientific genera and species names. Nomenclature generally follows recent literature, however, in some cases we have used names that are common use in the Floras of Laos and Vietnam.

- Synonyms are limited to those used in recent literature.

- Vernacular names have been cited using two main languages: Lao (L) and Vietnamese $(\mathrm{V})$.

- Descriptions are based on literature and herbarium specimens kept at Leiden (L) and Paris $(\mathrm{P})$.

- Distribution for the plant families is mentioned including the number of genera and species in the world, Laos, and Vietnam. Distribution within both countries is by province using the names as published in 'Flore du Cambodge, du Laos et du Vietnam' 31 (2003) 96.

- Habitat and ecology information include data on forest type, the habitats and altitude where the species are occurring, and the flowering and fruiting time.

- Data on uses.

\section{ACKNOWLEDGEMENTS}

This field guide is a reviewed version of the MSc theses of Hoang Van Sam and Khamseng Nanthavong under the supervision of P.J.A. Keßler at the Nationaal Herbarium Leiden, Universiteit Leiden branch.

We would like to thank the co-directors of the ASEAN Regional Centre for Biodiversity Conservation (ARCBC) for enabling HVS and KN to pursue their MSc at Leiden.

The director of the Nationaal Herbarium Nederland, P. Baas, the head of the Project Group Plant diversity of the Indo-Pacific and Tropical Asia, M.C. Roos, and the staff supported our activities. F.A.C.B. Adema, M.M.J. van Balgooy, Ding Hou, J.B. Mols, H.P. Nooteboom, W. Vink, P.C. van Welzen, and W.J.J.O. de Wilde kindly helped us with their expertise on various plant families.

Hoang Van Sam would like to thank the rector, the dean of the Forest Resources and Environment Management Faculty, the head of the Forest Plants department and his colleagues at the Vietnam Forestry University to enable him to study abroad and to support all his activities.

Khamseng Nanthavong received much support from the Ministry of Education, the rector of the National University of Laos and the dean of the Faculty of Forestry enabling him to pursue a MSc study in Leiden.

The director of the herbarium at P kindly allowed us to study the Indochinese collections during a visit and to borrow quite a lot of material. Th. Deroin supported us in various ways during our stay. S. Hul provided us with information concerning localities and general data on the Indochinese Flora. J.E. Vidal helped us in finding relevant literature especially for Laos.

We are very grateful to F.A.C.B. Adema for critically reading earlier versions of the manuscript. Ms. C.G.G. Baak kindly formatted the manuscript for which she is gratefully acknowledged. 
Miss Joanne Porck (NHN-Leiden) and Mr. Priono (The International Tropenbos Kalimantan project) made several original drawings for which we are thankful. The authors wish to express their gratitude to the curators of $\mathrm{P}$ and $\mathrm{BKF}$ for the permission to use illustrations from Flore du Cambodge, du Laos et du Vietnam and Thai Forest Bulletin.

\section{SELECTED LITERATURE}

Backer, C.A. \& R.C. Bakhuizen van den Brink Jr. 1964-1965. Flora of Java. Vol. 1, 2. Noordhoff, Groningen, The Netherlands.

Bân, N.T. 1996. Red data book of Vietnam. Vol. 2. Plants. Science \& Technics Publishing House, Hanoi, Vietnam.

Bân, N.T. 2000. Flora of Vietnam. Vol. 1. Science \& Technics Publishing House, Hanoi, Vietnam. (In Vietnamese.)

Bodegom, S., P.B. Pelser \& P.J.A. Keßler. 1999. Seedlings of secondary forest tree species of East Kalimantan, Indonesia. Tropenbos-Kalimantan Series 1. Balikpapan.

Callaghan, R.M. 1995. Plants of Laos. A list of tree species. Vientiane, Laos.

Chan, L.M. \& L.T. Huyen. 2000. Forest plants of Vietnam. Hanoi, Vietnam. (In Vietnamese.)

Corner, E.J.H. 1940. Wayside Trees of Malaya. Singapore.

De Vogel, E.F. (ed.). 1987. Manual of herbarium taxonomy. Theory and practice. UNESCO. Jakarta, Indonesia.

Dung, V.V. 1996. Vietnam Forest Trees. Hanoi, Vietnam.

Hooker, J.D. 1872-1890. Flora of British India. Vol. 3-5, London, United Kingdom.

Flora of China. 1999-2000. Vol. 4-24, Beijing, China.

Flora Malesiana. 1948-2000. Ser. 1, Vol.4-14. Nationaal Herbarium Nederland, Universiteit Leiden branch, The Netherlands.

Flora of Thailand. 1970-2002. Vol. 2-7. The Forest Herbarium, Royal Forest Department, Bangkok. Thailand.

Flore du Laos, du Cambodge et du Vietnam. 1960-2003. Vol. 1-31. Muséum National d'Histoire Naturelle, Laboratoire de Phanérogamie, Paris, France. (In French.)

Gardner, S., P. Sidisunthorn \& V. Anusarnsunthorn. 2000. A field guide to forest trees of northern Thailand. Kobfai Publishing Project, Bangkok, Thailand.

Hô, P.H. 1991-1992. Flora of Vietnam, Vol. 1, 2. Paris. (In Vietnamese.)

Ke, L.K. 1969-1977. The common plants in Vietnam. Vol. 1-6. Hanoi. (In Vietnamese.)

Keßler, P.J.A. (ed.) 2000. Secondary forest trees of Kalimantan, Indonesia. MOFEC TropenbosKalimantan Series 3. The Netherlands.

Lecomte, H. (ed.). 1907-1912. Flore Génerale de l'Indo-Chine. Vol. 1-5. Muséum National d'Histoire Naturelle, Laboratoire de Phanérogamie, Paris, France.

Lehmann, L., M. Greijmans \& D. Shenman. 2003. Forests and trees of the central highlands of Xieng Khouang Lao PDR, A field guide. Lao Tree Seed Project, Vientiane, Laos.

Prosea (Plant Resources of South-East Asia). 1993-2003. Vol. 5-17. PUDOC Scientific Publishers, Wageningen, The Netherlands.

Ridley, H.N. 1923-1925. Flora of Malay Peninsula. Vol. 1-15. Reeve \& Co, London, United Kingdom.

Tree Flora of Malaya. 1972-1989. Vol. 1-4. Forest Research Institute Malaysia, Kepong, Malaysia.

Tree Flora of Sabah and Sarawak. 1995-2002. Vol. 1-4. Forest Research Institute Malaysia, Kepong, Malaysia.

Trung, V.T. 1970. The vegetation of Vietnam. Hanoi, Vietnam. (In Vietnamese.)

Vidal, J.E. 1959. Noms vernaculaires de plantes (LAO, MÈO, KHA) en usage au Laos. Bull. de l'École Française d'Extrème-Orient 49: 435-608.

Vidal, J.E. 2000. Vegetation-types and plants of the Indochinese Peninsula. Ecocart, Paris, France. (CD-ROM). 


\section{FLORISTIC TREATMENT}

\section{SPOT CHARACTERS FOR THE GENERA}

List of spot characters

1 - Gymnosperms

2 - Bark with hissing sound when cut

3 - Armed plants

4 - Stem flanged

5 - Twigs with ridges

6 - Sap white

7 - Sap yellow

8 - Sap black or brown

9 - Sap red or orange

10 - Living parts of plants with smell

11 - Stellate hairs or scales present

12 - Glands on petiole

13 - Glands on leaf lamina

14 - Stipules present

15 - Stipules absent

16 - Petioles swollen

17 - Petioles wrinkled

18 - Winged rhachis or petiole

19 - Rhachis with swollen nodes

20 - Leaves opposite

21 - Leaves whorled

22 - Leaves spirally arranged

23 - Leaves alternate (in two rows)

24 - Leaves simple

25 - Leaves palmately compound or digitate

26 - Leaves pinnately compound

27 - Leaves bipinnately compound
28 - Leaves peltate

29 - Leaves trifoliolate

30 - Leaflets alternate

31 - Leaflets opposite

32 - Leaf or leaflet margin entire

33 - Leaf or leaflet margin toothed

34 - Leaves hairy

35 - Leaves or leaflets with dots

36 - Leaves or leaflets with domatia

37 - Leaves 3-veined

38 - Intramarginal vein present

39 - Leaves with very close parallel veins

40 - Inflorescences a spike

41 - Inflorescences in a head

42 - Flowers large and showy (at least $1.5 \mathrm{~cm}$ diam.)

43 - Ovary inferior

44 - Ovary superior

45 - Fruits compound

46 - Fruits dehiscent

47 - Fruits indehiscent

48 - Fruits with wing(s)

49 - Fruit a berry

50 - Fruit a cone

51 - Fruit a drupe

52 - Fruit a nut

53 - Fruit a capsule

54 - Fruit a pod

55 - Seeds winged

Spot characters

1. Gymnosperms

Cupressus, Dacrycarpus, Dacrydium, Fokienia, Keteleeria, Nageia, Pinus, Podocarpus

2. Bark with hissing sound when cut

Dillenia

3. Armed plants

Caesalpinia p.p., Erythrina p.p., Gmelina p.p., Pithecellobium p.p. 
4. Stem flanged Archidendron p.p.

5. Twigs with ridges

Duabanga

6. Sap white Aglaia p.p., Alstonia, Broussonetia, Canarium, Eberhardtia, Madhuca, Wrightia

7. Sap yellow

Mesua

8. Sap black or brown

Canarium p.p., Choerospondias, Dracontomelon

9. Sap red or orange

Bischofia, Dalbergia, Endospermum p.p., Horsfieldia, Knema, Pterocarpus

10. Living parts of plants with smell

Cananga, Canarium, Cinnamomun, Cupressus, Dracontomelon, Fokienia, Michelia

11. Stellate hairs or scales present

Aglaia, Aleurites, Bombax p.p., Endospermum, Lagerstroemia, Pterospermum

12. Glands on petiole

Archidendron, Terminalia p.p.

13. Glands on leaf lamina

Diospyros, Endospermum, Fagraea, Gmelina, Terminalia p.p., Vatica

14. Stipules present

Acrocarpus, Adenanthera, Afzelia, Albizia, Aleurites, Altingia, Anisoptera, Archidendron, Baccaurea, Berrya, Betula, Bischofia, Bombax, Broussonetia, Caesalpinia, Canarium p.p., Cassia, Castanea, Castanopsis, Dalbergia, Delonix, Dialium, Dipterocarpus, Duabanga, Eberhardtia, Erythrina, Fagraea, Hopea, Irvingia, Liquidambar, Madhuca, Michelia, Parashorea, Parkia, Peltophorum, Pithecellobium, Pterocarpus, Pterospermum, Pyrus, Samanea, Senna, Sindora, Tamarindus, Vatica, Xylia

15. Stipules absent

Alstonia, Cananga, Canarium p.p., Chisocheton, Choerospondias, Chukrasia, Dillenia, Diospyros, Dracontomelon, Gmelina, Horsfieldia, Knema, Lagerstroemia, Mesua, Oroxylum, Polyalthia, Sapindus, Schima, Syzygium, Tectona, Terminalia, Tetrameles, Wrightia, Xylopia

16. Petioles swollen

Aglaia p.p., Aleurites, Anisoptera, Baccaurea, Dipterocarpus, Endospermum, Pterospermum 
17. Petioles wrinkled

Diospyros p.p., Syzygium p.p.

18. Winged rhachis or petiole

Dillenia p.p., Tectona

19. Rhachis with swollen nodes

Archidendron, Oroxylum indicum

20. Leaves opposite

Duabanga, Fagraea, Gmelina, Lagerstroemia, Markhamia, Mesua, Oroxylum, Syzygium, Tectona, Terminalia, Wrightia

21. Leaves whorled

Alstonia, Terminalia p.p.

22. Leaves spirally arranged

Aleurites, Dillenia, Dracontomelon, Endospermum, Senna, Terminalia p.p.

23. Leaves alternate (in two rows)

Aquilaria, Bombax, Caesalpinia, Cananga, Diospyros, Dipterocarpus, Duabanga, Erythrina, Polyalthia, Terminalia, Xylopia

24. Leaves simple

Aleurites, Alstonia, Altingia, Anisoptera, Aquilaria, Baccaurea, Berrya, Bischofia,

Broussonetia, Cananga, Castanea, Castanopsis, Dillenia, Diospyros, Dipterocarpus, Duabanga, Eberhardtia, Endospermum, Fagraea, Gmelina, Horsfieldia, Knema, Lagerstroemia, Liquidambar, Irvingia, Madhuca, Mesua, Michelia, Parashorea, Polyalthia, Pterospermum, Schima, Shorea, Syzygium, Tectona, Terminalia, Vatica, Wrightia, Xylopia

25. Leaves palmately compound or digitate

Bombax

26. Leaves pinnately compound

Aglaia, Canarium, Cassia, Chisocheton, Choerospondias, Chukrasia, Dracontomelon, Markhamia, Pterocarpus, Sapindus, Senna

27. Leaves bipinnately compound

Acrocarpus, Archidendron, Caesalpinia, Oroxylum (sometimes 3-pinnate), Parkia, Peltophorum

28. Leaves peltate

Endospermum p.p., Pterospermun

29. Leaves trifoliolate

Bischofia, Erythrina

30. Leaflets alternate

Chukrasia, Dalium, Dracontomelon, Sapindus 


\section{Leaflets opposite}

Acrocarpus, Afzelia, Aglaia, Caesalpinia, Canarium, Chisocheton, Choerospondias, Delonix, Dracontomelon, Markhamia, Oroxylum, Peltophorum, Sindora, Tamarindus

\section{Leaf or leaflet margin entire}

Acrocarpus, Afzelia, Aglaia, Aleurites, Alstonia, Anisoptera, Aquilaria, Archidendron, Caesalpinia, Cananga, Cassia, Cinnamomum, Delonix, Dialium, Diospyros, Dipterocarpus, Dracontomelon, Duabanga, Eberhardtia, Endospermum, Fagraea, Gmelina, Hopea, Horsfieldia, Knema, Lagerstroemia, Madhuca, Michelia, Oroxylum indicum, Parashorea, Parkia, Peltophorum, Polyalthia, Pterocarpus, Pterospermum, Senna, Shorea, Sindora, Syzygium, Tamarindus, Vatica, Wrightia, Xylopia

33. Leaf or leaflet margin toothed

Altingia, Betula, Bischofia, Castanea, Castanopsis, Choerospondias, Dillenia p.p., Gmelina p.p., Markhamia, Schima, Terminalia, Tetrameles

34. Leaves hairy

Broussonetia, Wrightia

35. Leaves or leaflets with dots

Aglaia p.p., Caesalpinia, Cananga, Cinnamomun, Diospyros, Syzygium, Terminalia

36. Leaves or leaflets with domatia

Chukrasia, Dracontomelon, Hopea, Terminalia

37. Leaves 3-veined

Cinnamomun

38. Intramarginal vein present

Duabanga, Syzygium

39. Leaves with very close parallel veins

Alstonia, Mesua

40. Inflorescences a spike

Castanea, Castanopsis, Betula, Broussonetia (male), Keteleeria (male), Liquidambar (male), Pinus (male), Podocarpus (male)

41. Inflorescences in a head

Altingia (female), Broussonetia (female), Liquidambar (female)

42. Flowers large and showy (at least $1.5 \mathrm{~cm}$ diam.)

Bombax, Cananga, Delonix, Dillenia, Gmelina, Markhamia, Mesua, Michelia, Oroxylum, Senna

43. Ovary inferior

Altingia, Anisoptera, Anogeissus, Betula, Castanea, Castanopsis, Lagerstroemia, Liquidambar, Pyrus, Syzygium, Terminalia, Tetrameles 


\section{Ovary superior}

Acrocarpus, Adenanthera, Afzelia, Aglaia, Albizia, Aleurites, Alstonia, Aquilaria, Archidendron, Baccaurea, Berrya, Bischofia, Bombax, Broussonetia, Caesalpinia, Cananga, Canarium, Cassia, Chisocheton, Choerospondias, Chukrasia, Cinnamomum, Dalbergia, Delonix, Dialium, Dillenia, Diospyros, Dipterocarpus, Dracontomelon, Duabanga, Eberhardtia, Endospermum, Erythrina, Fagraea, Gmelina, Hopea, Horsfieldia, Irvingia, Knema, Lagerstroemia, Madhuca, Markhamia, Mesua, Michelia, Oroxylum, Parashorea, Parkia, Peltophorum, Pithecellobium, Polyalthia, Pterocarpus, Pterospermum, Samanea, Sapindus, Schima, Senna, Shorea, Sindora, Tamarindus, Tectona, Vatica, Wrightia, Xylia, Xylopia

45. Fruits compound

Broussonetia

46. Fruits dehiscent

Acrocarpus, Adenanthera, Afzelia, Aglaia, Albizia, Alstonia, Altingia, Aquilaria, Archidendron, Berrya, Bombax, Caesalpinia, Chisocheton, Chukrasia, Delonix, Eberhardtia, Erythrina, Horsfieldia, Knema, Lagerstroemia, Liquidambar, Markhamia, Mesua, Oroxylum, Peltophorum, Pithecellobium, Pterospermum, Schima, Sindora, Tetrameles, Wrightia, Xylia

47. Fruits indehiscent

Anisoptera, Anogeissus, Cananga, Cassia, Choerospondias, Dalbergia, Dialium, Dillenia, Dipterocarpus, Dracontomelon, Gmelina, Hopea, Parashorea, Parkia, Polyalthia, Pterocarpus, Samanea, Senna, Shorea, Tamarindus, Tectona grandis, Terminalia, Vatica, Xylopia p.p.

48. Fruit with wing(s)

Anisoptera, Anogeissus, Betula, Dipterocarpus, Hopea, Parashorea, Pterocarpus, Shorea, Terminalia, Vatica

49. Fruit a berry

Baccaurea, Diospyros, Duabanga, Madhuca, Pyrus, Syzygium

50. Fruit a cone

Cupressus, Dacrycarpus, Dacrydium, Fokienia, Keteleeria, Nageia, Pinus, Podocarpus

51. Fruit a drupe

Aleurites, Baccaurea, Bischofia, Cananga, Canarium, Choerospondias, Cinnamomum, Dracontomelon, Endospermum, Fagraea, Gmelina, Irvingia, Polyalthia, Sapindus, Tectona grandis, Xylopia

\section{Fruit a nut}

Anisoptera, Betula, Castanea, Castanopsis, Dipterocarpus, Hopea, Parashorea, Shorea p.p., Vatica p.p. 


\section{Fruit a capsule}

Aglaia, Alstonia, Altingia, Aquilaria, Berrya, Bombax, Chisocheton, Chukrasia, Eberhardtia, Horsfieldia, Knema, Lagerstroemia, Liquidambar, Mesua, Pterospermum, Schima, Tetrameles, Wrightia

\section{Fruit a pod}

Acrocarpus, Adenanthera, Afzelia, Albizia, Alstonia, Archidendron, Bombax, Caesalpinia, Cassia, Dalbergia, Delonix, Dialium, Erythrina, Markhamia, Oroxylum, Parkia, Peltophorum, Pithecellobium, Pterocarpus, Samanea, Senna, Sindora, Tamarindus, Wrightia, Xylia

55. Seeds winged

Chukrasia, Keteleeria, Lagerstroemia, Markhamia, Oroxylum, Pinus, Pterospermum, Schima

\section{KEYS}

\section{KEYS TO THE GROUPS}

1a. Secondary wood without true vessels, ovules born on the surface of open carpels

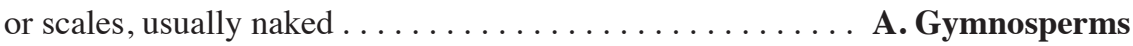

b. Secondary wood with true vessels, ovules surrounded by carpels, forming a closed

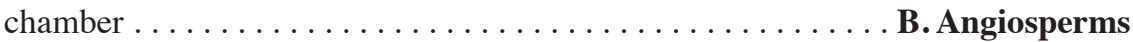

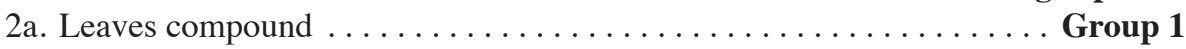

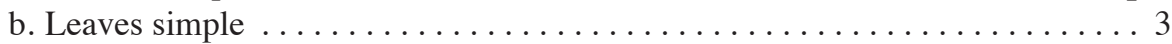

3a. Leaves opposite, rarely subopposite or whorled $\ldots \ldots \ldots \ldots$ Group 2

b. Leaves spirally arranged or alternate . . . . . . . . . . . . . . . 4

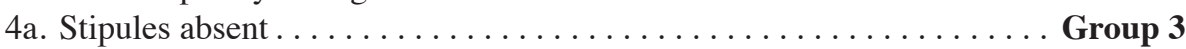

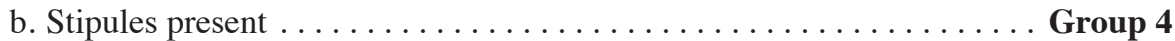

\section{KEYS TO THE FAMILIES}

\section{A. GYMNOSPERMS}

1a. Sap absent, if present not resinous. Leaves solitary $\ldots \ldots \ldots \ldots \ldots \ldots \ldots$

b. Resin present. Leaves solitary, paired or tufted. - Pollen sacs 2. Female bracts in a spiral, seeds usually winged $\ldots \ldots \ldots \ldots \ldots \ldots$ Pinaceae

2a. Leaves usually scale-like, decussate or whorled. Pollen sacs usually 3 or more, rarely 2 . Mature female cones with $2-15$ seeds. Seeds not winged or with $1-3$

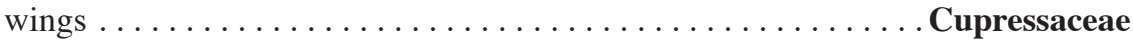

b. Leaves needle-, scale-, or leaf-like, usually spirally arranged, alternate or opposite. Pollen sacs 2 . Mature female cone with only 1 seed. Seeds not winged. . . . . . . 


\section{B. ANGIOSPERMS}

Group 1: Leaves compound

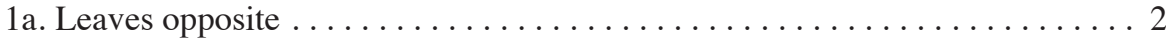

b. Leaves spirally arranged or alternate $\ldots \ldots \ldots \ldots \ldots \ldots \ldots \ldots \ldots$

2a. Leaves pinnate, bipinnate, or tripinnate. Fruit pod-like. . . . . . Bignoniaceae

b. Leaves trifoliolate or palmate. Fruit a drupe or capsule . . . . . . . Verbenaceae

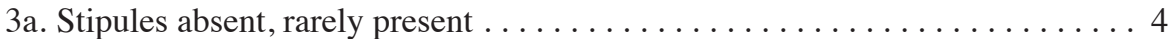

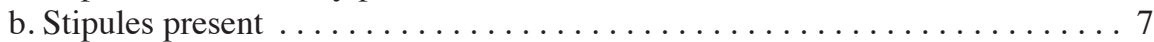

4a. Sap present, living parts usually with aromatic or turpentine smell $\ldots \ldots \ldots 5$

b. Sap usually absent, rarely present, living parts without smell . . . . . . . 6

5a. Sap black when exposed to the air. Stipules absent. Living parts with turpentine

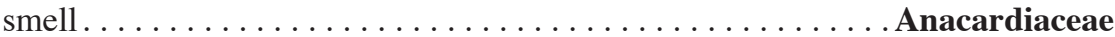

b. Sap usually white or watery, rarely black. Stipules present or absent. Living parts usually with aromatic, resinous smell . ............. Burseraceae

6a. Bark usually smooth. True stipules absent but pseudostipules sometimes present. Stamens free. Seeds completely or partially covered by an aril . . . Sapindaceae

b. Bark smooth, fissured, scaly or flaky. Stipules absent. Stamens usually partly or completely united into a tube or globose head. Seeds winged or covered by an

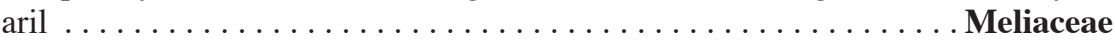

7a. Leaves trifoliolate, palmate, or digitate. Fruit a capsule $\ldots \ldots \ldots \ldots \ldots \ldots$

b. Leaves usually pinnate or bipinnate. Fruit a pod . . . . . . . . . . . 9

8a. Bark usually with sharp conical thorns. Sap absent. Leaves scaly. Flowers large and showy. Fruit an elliptic capsule, splitting in 5 parts Bombacaceae (Bombax)

b. Thorns absent. Sap red. Leaves with simples hairs. Fruit a globose capsule, split-

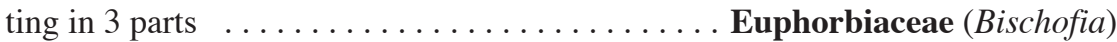

9a. Leaves usually pinnate, rarely bipinnate or digitate, usually without glands on the rhachis. Flowers often irregular, rarely regular, usually in racemes, panicles or

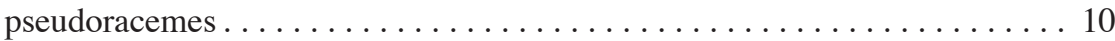

b. Leaves usually bipinnate, often with glands on the rhachis. Flowers regular, in globose heads or spikes, rarely racemosely arranged . . . . . . . Mimosaceae

10a. Flowers mostly irregular (pea-flower shaped), stamens usually 10 , all united in a tube or in 2 groups $(1+9)$ or $(5+5)$, sometimes free . . . . . . . Fabaceae

b. Flowers regular or irregular. Stamens 10 , or fewer sometimes 1 , free, rarely united at the base.

Caesalpiniaceae

Group 2: Leaves simple: opposite, rarely subopposite or whorled

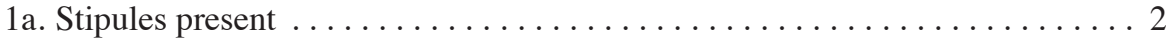

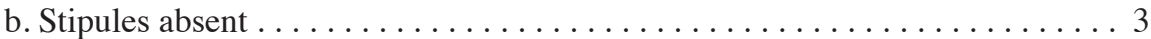

2a. Twigs angular. Flowers large and showy, sepals connate into tube, leathery. Fruit indehiscent resting on the calyx tube ......... Sonneratiaceae (Duabanga)

b. Twigs terete. Flowers usually not large and showy, sepals united or free. Fruit indehiscent or dehiscent, calyx not persistent . . . . . . Loganiaceae (Fagraea)

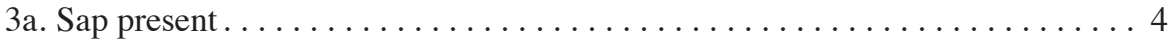

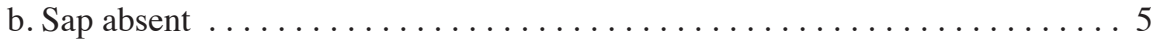


4a. Sap white. Leaves opposite or whorled, without dots. Calyx not persistent in fruit. Fruits usually paired, seeds winged or with tuft(s) of hairs at one or both ends ...

Apocynaceae

b. Sap usually yellow, rarely white. Leaves always opposite, with dots. Calyx persistent in fruit. Fruit single, seeds not winged.

5a. Young twigs quadrangular. Corolla usually 2-lipped. Stamens 5, 4, or 2 ................................. Verbenaceae

b. Young twigs usually terete. Corolla variously shaped, stamens 5 or more . . . 6

6a. Leaves usually either with domatia or oil dots. Ovary superior or inferior. Fruit a berry, a capsule or winged, rarely a drupe . . . . . . . . . . . 7

b. Leaves usually without domatia or oil dots. Ovary half inferior. Fruit a capsule . . $\ldots \ldots \ldots \ldots \ldots \ldots \ldots \ldots \ldots \ldots \ldots \ldots \ldots \ldots \ldots \ldots \ldots \ldots \ldots \ldots \ldots$ Lythraceae

7a. Leaves without intramarginal vein and oil glands, but often conspicuously scaly, domatia usually present. Ovary superior. Fruit usually a $2-5$-winged drupe . . . . .

Combretaceae

b. Leaves often with intramarginal vein, usually finely dotted with oil glands, not scaly, domatia absent. Ovary inferior. Fruit a berry, a capsule, rarely a drupe, never winged . .

Myrtaceae

Group 3: Leaves simple: spirally arranged or alternate, stipules absent

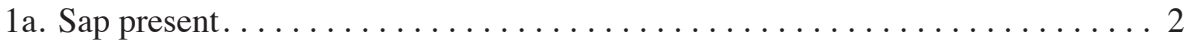

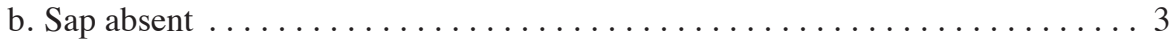

2a. Sap usually white. Leaves spirally arranged and frequently crowded at the end of twigs. Fruit usually a berry, rarely a drupe or capsule. Sepals persistent at base and styles persistent at apex. Aril absent . . . . . . . . . . . Sapotaceae

b. Inner bark with red sap. Leaves alternate, usually distichous. Fruit a capsule. Sepals and style not persistent. Seeds with red or orange-red, fleshy aril Myristicaceae

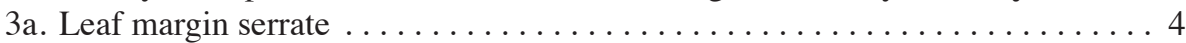

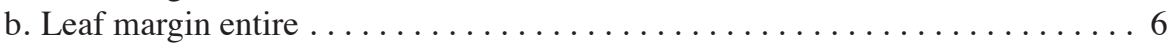

4a. Petiole sometimes winged. Secondary veins straight, parallel toward the margin. Fruit fleshy, covered by persistent sepals . . . . . . . . . Dilleniaceae

b. Petiole never winged. Secondary veins curving towards the margin. Fruit a cap-

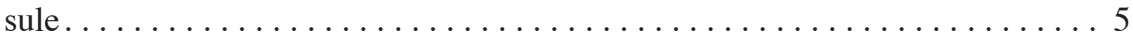

5a. Flowers usually large and showy, petals large. Stamens numerous. Ovary superior. Fruit with persistent calyx at base and style at apex . . . . . . Theaceae

b. Flowers usually small, petals absent. Stamens 4. Ovary inferior. Fruit with calyx

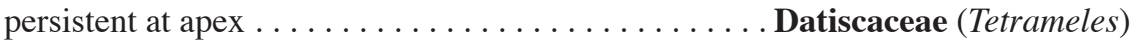

6a. Living parts usually with smell. Flowers 3 -merous. . . . . . . . . . . 7

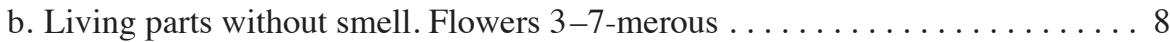

7a. Inner bark with conspicuous wedge-shaped fibre bundles. Living parts usually with smell, but not strongly aromatic. Stamens usually numerous. Carpels many, free.

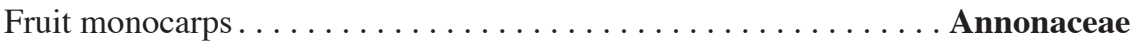

b. Inner bark without conspicuous wedge-shaped fibre bundles. Living parts often with strong aromatic smell. Stamens 9-12. Carpels connate. Fruit a drupe, usually with persistent perianth at base $\ldots \ldots \ldots \ldots \ldots$ Lauraceae 
8a. Bark black, usually not tough or fibrous. Leaves usually with black dots on one or both surfaces. Stamens usually 10-20. Fruit a berry with enlarged sepals at base

Ebenaceae (Diospyros)

b. Bark not black, usually tough or fibrous. Leaves without black dots. Stamens $2-10$. Fruit a capsule . . . . . . . . . . . Thymelaeaceae (Aquilaria)

Group 4: Leaves simple: spirally arranged or alternate, stipules present

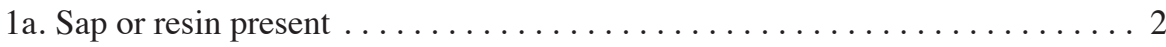

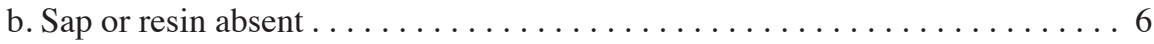

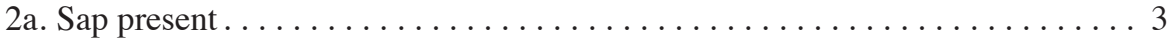

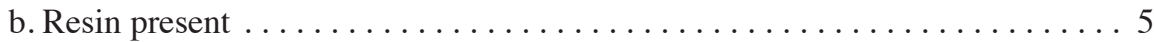

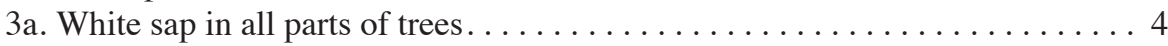

b. Sap clear, watery. - Fruit usually 3 -lobed $\ldots \ldots \ldots \ldots \ldots \ldots \ldots \ldots$

. Euphorbiaceae (Aleurites, Endospermum)

4a. Inner bark pink or red. Leaves spirally arranged and frequently crowded at the end of twigs. Fruit usually a berry, rarely a drupe or capsule. Sepals persistent at

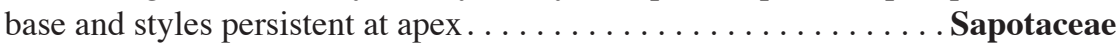

b. Inner bark usually cream or white. Leaves mostly alternate. Fruit united into a large fleshy compound structure $\ldots \ldots \ldots \ldots \ldots \ldots \ldots \ldots \ldots$ Moraceae

5a. Buds often enclosed in scales. Leaves usually palmately lobed, domatia absent. Sepals and petals 4 or 5, but usually small, sometimes absent. Fruit a head. . . .

Altingiaceae

b. Buds not enclosed in scales. Leaves entire, often with domatia. Sepals and petals 5. Fruits usually a $2-5$-winged (from calyx) nut. . . . . . Dipterocarpaceae

6a. Inner bark usually with spicy smell. Stipules large, enclosing the young bud, soon falling and leaving ring-like scars on the twigs . . . . . . . Magnoliaceae

b. Inner bark without spicy smell. Stipule not enclosing the young bud, not leaving

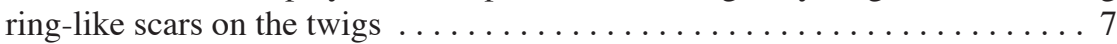

7a. Leaves usually crowed at top of twigs. Raised glands usually present on lower surface. Stipules mainly triangular. Fruit a berry. . Euphorbiaceae (Baccaurea)

b. Leaves usually not crowed at top of twigs. Raised glands absent on lower surface. Stipules usually linear, ovate, sometimes splitted. Fruit usually a nut or a

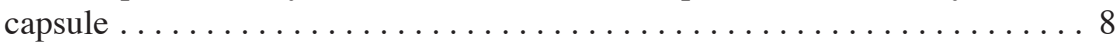

8a. Stellate hairs or scales usually present. Bark usually fibrous $\ldots \ldots \ldots \ldots \ldots 9$

b. Stellate hairs or scales usually absent, rarely present. Bark usually not fibrous 11

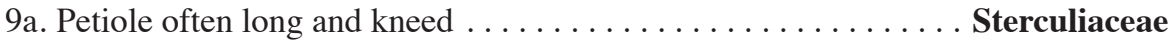

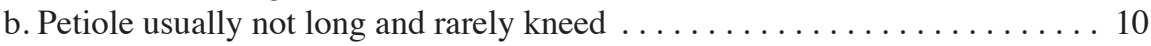

10a. Bark often with sharp conical thorns. Flowers large and showy, stamens many and connate into bundles. Fruit a woody capsule, never winged.

Bombacaceae (Bombax)

b. Bark without sharp conical thorns. Flowers usually small, stamens many and free or connate only at base. Fruit a (winged) capsule ........ Tiliaceae (Berrya)

11a. Stipules sword-like, free or sometimes adnate to the petiole. Fruit a drupe or pear-

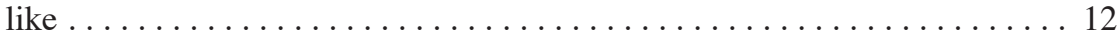

b. Stipules usually small, free. Fruit a nut $\ldots \ldots \ldots \ldots \ldots \ldots \ldots \ldots \ldots$ 
12a. Stipules sword-like, free, enclosing the terminal bud. Leaf margin entire. Petiole grooved above. Stamens 10. Fruit a drupe............. Irvingiaceae

b. Stipules filiform or linear, sometimes adnate to the petiole, not enclosing the terminal bud. Leaf margin usually serrate. Stamens numerous. Fruit pear-like . .

Rosaceae (Pyrus)

13a. Leaves usually double serrate, domatia usually present. Inner bark without tannin, but contains oil, cambium smooth. Fruit a winged nut . . . Betulaceae (Betula)

b. Leaves entire or serrate but not double serrate, domatia absent. Inner bark with much tannin, darkening on exposure, cambium furrowed. Fruit a nut Fagaceae

\section{A. GYMNOSPERMAE}

\section{CUPRESSACEAE}

Trees or shrubs, monoecious or dioecious, predominantly evergreen (deciduous in Taxodium), resinous and aromatic in all or some parts. Leaves simple, usually scalelike, decussate or whorled. Male cones ovoid, solitary, axillary or terminal, usually comprising only a few microsporophylls, with staminiferous scales, pollen sacs 2-7. Female cones terminal or axillary, solitary or in fascicles, consisting of scales with 2-15 ovules. Ripe female cones woody, or sometimes fleshy and berrylike, scales with apical tip, splitting open or not. Seed variable, winged or not (seed wings derived from the seed coat), resin glands present, cotyledons 2, sometimes 4, vein 1 .

Distribution - Tropical, subtropical and temperate areas: 22 genera, 150 species. In Laos: 2 genera, 2 species. In Vietnam: 6 genera, 8 species.

\section{KEY TO THE GENERA}

1a. Upper and lower surface of leaves green, with a resinous furrowed gland at lower surface. Male cones usually with $8-12$ pairs of stamens. Female cones with 6-8(-14) pairs of scales. Seeds 6-8 per scale, with 2 equal wings 1. Cupressus

b. Upper surface of leaves green, lower one white due to waxy stomatal depressions, gland absent at lower surface. Male cones with 14-16 pairs of stamens. Female cones with 5-8 pairs of scales. Seeds 2 per scale, with 2 very unequal wings. ...

\section{Fokienia}

\section{CUPRESSUS L.}

Cupressus funebris Endl. - Fig. 1

Synonym - Cupressus tonkinensis Silba

Vernacular name - Hoàng đàn $(\mathrm{V})$.

Evergreen, medium sized trees up to $25 \mathrm{~m}$ high, 40-90 cm diameter. Bark greyish brown, with longitudinal fissures. Twigs cylindrical, nearly quadrangular, two sides of leaves green. Branches in whorls. Crown large, oval in shape. Leaves scaly, in 4 rows, imbricate, apex obtuse, margins denticulate, with a resinous furrowed gland at lower 

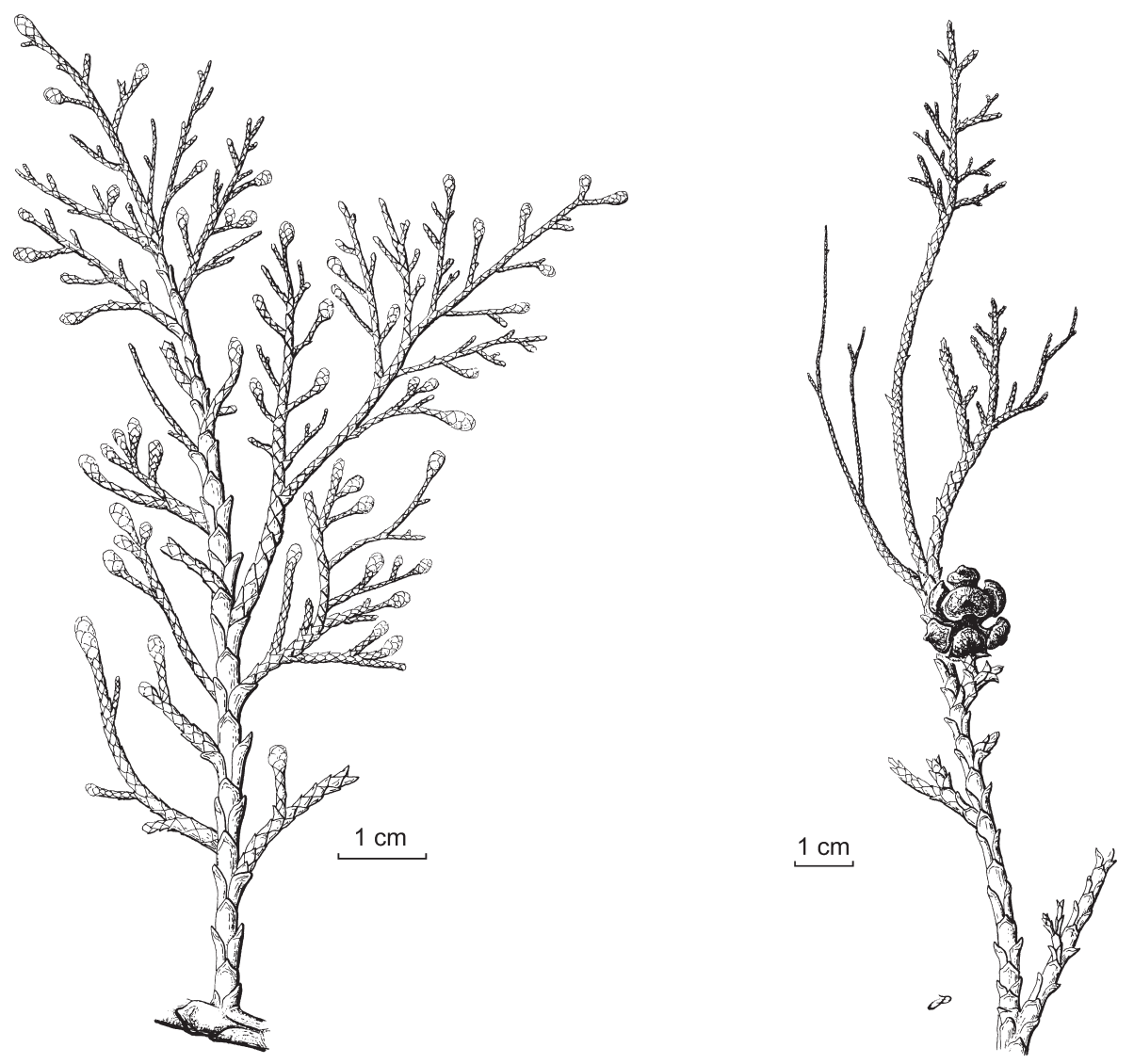

Fig. 1. Cupressus funebris Endl. (Cupressaceae).

surface. Cones unisexual. Male cones cylindrical-oblong, 5-6 $\mathrm{mm}$ long, pedicel of cones short, 3-10 mm long, usually consisting of 8-12 pairs of stamens with an ovate connective, and 3 or 4 pollen sacs. Female cones subglobose or ovate, less than $1.5 \mathrm{~cm}$ diam., formed by $4-8$ scales, tip mucronate. Seeds $6-8$ per scale, subglobose, c. $4 \mathrm{~mm}$ long, green when young, dark brown when mature, compressed laterally, sometimes triquetrous, with 2 equal wings.

Distribution - West Himalaya (Nepal, Bhutan), South China, Vietnam. An endangered species in Vietnam, only found in a narrow belt in North Vietnam, belonging to Lang Son (Huu Lung, Chi Lang), Tuyên Quang (Na Hang), and Hà Giang (Dong Van) provinces. This species does not occur in Laos.

Habitat \& Ecology - Found in hot and wet tropical and subtropical forests, altitude 250-3000 m, mixed with Burretiodendron hsienmu and Markhamia stipulata on limestone mountains, sometimes forming pure stands on mountain slopes, ridges, and tops. Rather slow growing, natural regeneration very limited. Cones: February, March; mature ones: May, June of the next year. 
Uses - Wood with straight grain and fine texture, resistant to termites and insects, with aromatic smell. Used for cabinetwork, furniture, and fine art articles. Wood, especially the root wood, contains essential oils that are used as medicine to cure inflammatory wounds, or as an antiseptic; it is also used in the cosmetic industry.

Note - Older references for Vietnamese conifers, identify Cupressus trees found in Lang Son and north-eastern Vietnam as C.torulosa D. Don. This species is restricted to the Himalayas although it is cultivated in highland areas of Vietnam and may be naturalised in some places (Lâm Dông). Natural and many cultivated trees from Lang Son are definitely not $C$. torulosa.

Specimens examined: Cooper 5793 (P); Falconer 994 (P); Jacquemont 1999, s.n.(P); Pierre 159 (P); Strachey s.n. (P).

\section{FOKIENIA A. Henry \& H.H. Thomas}

\section{Fokienia hodginsii (Dunn) A. Henry \& H.H. Thomas}

Synonyms - Cupressus hodginsii Dunn; Fokienia maclurei Merr.

Vernacular names - Lang len, Leng le (L); Pơ mu (V).

Trees up to $35 \mathrm{~m}$ high, up to $200 \mathrm{~cm}$ diam., bole straight, crown pyramidal. Bark brown grey, peeling off when young, later longitudinally fissured, aromatic. Leaves dimorphic, scaly, arranged in flattened tripinnate branchlet systems, the pinnae disposed in one plane, the branchlets tapering above. Leaves on adult trees arising in whorls of 4 at the same level, subacute, about $2 \mathrm{~mm}$ long, lateral leaves ovate, compressed, with white stomatal depressions on the ventral surfaces, facial leaves narrow obovate with a triangular apex, furrowed above. Internodes longer on older branchlets, the leaves rising at different levels in alternately opposite pairs. Leaves on young plants larger, about $8 \mathrm{~mm}$ long with spine-like points. Male cones oval to cylindrical, axillary, solitary, pedicle 5-20 mm long, cones about 7-12 $\mathrm{mm}$ long, with 3-5 pairs of scales, with 14-16 orbicular stamens each with 3 or 4 pollen sacs. Female cones globose or subglobose, $1.5-2.5 \mathrm{~cm}$ diam., shortly stalked, composed of 6-8 pairs of scales, each with a central spine or short process. Seeds 2 on each fertile scale, about $4 \mathrm{~mm}$ long, angular, pointed, with 2 large resin blisters on the upper and lower surface, wings lateral, very unequal.

Distribution - China (Zhejiang, Fujian, Guizhou, Yunnan) and Indochina. In Laos: Houa Phan, Xieng Khouang, and Bolikhamsai provinces. In Vietnam: Dac Lac, Gia Lai, Dông Nai, Khanh Hoa, Lâm Dông, Hà Bac, Hà Giang, Hà Tỉnh, Hoa Binh, Kon Tum, Lai Châu, Lào Cai, Nghê An, Son La, Thanh Hoa, Tuyên Quang, Kien Gian, and Yên Bai provinces.

Habitat \& Ecology - Fokienia hodginsii is a shade-intolerant species, well adapted to mild climates with abundant rainfall, occurring naturally on humid soils in high mountain areas, slopes or plains. In Vietnam it is found at altitudes above $900 \mathrm{~m}$ on granite or limestone mountains, forming pure stands or mixed with Dacrydium elatum, Pinus dalatensis, and other broad-leaved tree species of the families Fagaceae, Lauraceae, and Magnoliaceae. Sufficient natural regeneration occurs in open areas, e.g. along streams, at forest edges, and in clearings in young forests. Cones: March, April; mature ones: September to December of the next year. 
Uses - Wood is light, fine, and aromatic with straight grains and can be made into valuable furniture, art articles, and produces charcoal of high heat value. The distillation of wood, especially that of the roots, gives a high value essential oil, used for cosmetics.

Specimens examined: Chevalier 29391, 29493 (P); Hiep et al.403, 1437 (P); Krempe 1599 (P); Pételot s.n.(P); Poilane 3462, 3521, 3539, 4397, 6500, 6527, 18742, 31056, 32545 (P); Schmid 858 (P), 859 (L).

\section{PINACEAE}

Normally big, monoecious trees, with resin. Branches whorled, scaly. Leaves usually persistent, alternate or spirally arranged, linear or awl-shaped. Male cones axillary, sometimes in groups at the end of twigs. Male flowers with 2-locular anthers. Female cones axillary. Female flowers in axils of scales and bracts. Fruit cone scales woody. Seeds usually with a large wing. Cotyledons many, above the ground.

Distribution - In all temperate regions: c. 11 genera, 200 species. In Laos: 2 genera, 3 species. In Vietnam: 4 genera, 10 species.

\section{KEY TO THE GENERA}

1a. Leaves single, linear, thin, flattened, twisted at base, 2-4 mm wide $\mathbf{1}$. Keteleeria

b. Leaves $2-5$ in fascicles, needle-like, $0.5-1 \mathrm{~mm}$ wide, enclosed around the base by a sheath of scale leaves $\ldots \ldots \ldots \ldots \ldots \ldots \ldots \ldots \ldots \ldots \ldots \ldots$. Pinus

\section{KETELEERIA Carrière}

\section{Keteleeria evelyniana Mast.}

Synonyms - Keteleeria davidiana Beissn.; K. delavayi Tiegh.; K. dopiana Flous; K. roulletii (A. Chev.) Flous; Tsuga roulletii A. Chev.

Vernacular names - Hing (L); Du sam, Ngo tùng (V).

Big trees up to $40 \mathrm{~m}$ high, up to $130 \mathrm{~cm}$ diameter. Bark grey-brown scaly. Bud ovate, short, glabrous. Leaves alternate or spirally arranged, single, persistent, linear, flattened, usually $(20-) 30-70(-90)$ by $20-40 \mathrm{~mm}$, base cuneate, slightly twisted, apex acute or rounded. Midrib raised above, at both sides with a white stripe of stomata. Male flowers in lateral or terminal fascicles. Female flowers in erect, solitary cones. Cones lateral or subterminal, ovoid, cylindrical, $12-20$ by $3-6 \mathrm{~cm}$, ripening every year, woody, persistent; scales rhomboid, more or less auriculate at the base, densely striate on the scales, margin denticulate. Seeds shiny, ovate, up to $26 \mathrm{~mm}$ long, with large resin cavities, winged, 15 by $10 \mathrm{~mm}$, yellow-brown.

Distribution - South China, Myanmar, Thailand, Indochina. In Laos: Houa Phan, Xieng Khouang, Bolikhamsai (Khamkeut District), Khammouane, Saravane, and Champassak (Bolaven) provinces. In Vietnam: Lai Châu, Son La, Hoa Binh, Thua Thien Hue, Kon Tum (Ngoc Linh), Nghê An, Lâm Dông (Dalat city), Dac Lac, Khanh Hoa, and Ninh Thuân provinces. 
Habitat \& Ecology - In primary, secondary forest, in moist evergreen and mixed conifer-broadleaved forest together with Fagaceae and Alstonia species. Sometimes near streams, in Dipterocarp forest, dry evergreen hill forests, at high altitudes of (500-)800-1600(-2000) $\mathrm{m}$.

Uses - Wood is used for construction, house posts, boards and roof shingles, household furniture; the resin of the bark is used for medicine; oil of the seeds is used for burning as incense and in soap manufacturing; young shoots are used for papermaking.

Specimens examined: Chevalier 30025 (P); Colani s.n. (P); Evrard $1048(\mathrm{P})$; Hayata $642(\mathrm{P})$; Jacquet $578(\mathrm{P})$; Kerr 20971 (P); Krempf s.n.(P); Lecomte 1542, 1584 (P); Mieville 27070, $37068(\mathrm{P})$; Pételot s.n.(P); Poilane 1959, 16188, 20064 (P), 16188 (L); Spire 494, 1505 (P); Tixier 20 (P).

\section{PINUS L.}

Evergreen monoecious trees or rarely shrubs. Bark smooth or rough, particularly in older trees, peeling in flakes with very irregular shape. Leaves linear, often with minute serrations, spirally arranged, soon replaced by scales in the axils of which appear reduced shoots in the form of bundle-like leaves enclosed around the base by a sheath of membranous scale leaves. Adult leaves in bundles, linear, sharp, needle-like, 0.5-1 mm wide. Pollen cones numerous, axillary, cylindrical, subtended by a cluster of overlapping scales similar to those of the foliage bud, microsporophylls scale-like with two inverted pollen sacs. Seed cones terminal on short scaly shoots, more or less cylindrical, ovoid, consisting of numerous fertile scales which become woody, ripening in the second or third year, the apiculate bract fused with the scale, two inverted ovules on each scale. Seeds egg-shaped (ovate), expanded wing is attached to the broad base of the seed.

\section{KEY TO THE SPECIES}

1a. Leaves three per bundle. Bark reddish brown when old. Mature seed cone globu-

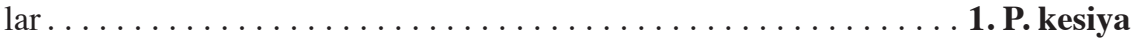

b. Leaves two per bundle. Bark dark brown or blackish when old. Mature seed cone

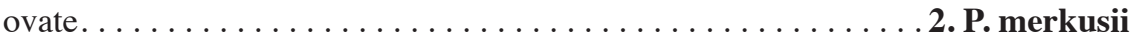

\section{Pinus kesiya Royle ex Gordon}

Synonyms - Pinus insularis Endl.; P. khasya Hook.f.; P. langbianensis A. Chev.

Vernacular names - Paek sam bai (L); Thông ba lá (V).

Big trees up to $45 \mathrm{~m}$ high, 60-80 $\mathrm{cm}$ diameter. Trunk straight, cylindrical, resinous. Bark thick, reddish brown when old, deeply fissured longitudinally, breaking off in small thick irregular plates and thus sometimes becoming smoother and plate-like. Crown pyramidal when young, rounded when old. Branchlets smooth, bright brown. Foliage buds cylindrical and non-resinous with brown awl-shaped scales. Needles three together, $12-24$ by $0.5 \mathrm{~mm}$, acuminate, stomata on both surfaces, caducous after two years. Basal sheath 5-18 mm long, greyish brown. Male cones $18-30$ by $5 \mathrm{~mm}$. 
Female cones ovoid to conical before opening, $4.5-10$ by $3-5 \mathrm{~cm}$, usually persistent. Seeds $5-8$ by $3 \mathrm{~mm}$, with a thin wing, 20 by $8 \mathrm{~mm}$.

Distribution - East India, East Myanmar, China, Thailand, Indochina, Malaysia, Philippines. In Laos: Louang Namtha (Sing Distr.), Houa Phan, Xieng Khouang (Paek, Phoukoud, Paxay districts), Vientiane and Bolikhamsai (Phou Khao Khouay NBCA), Khammouane (Nakai), Saravane, Sekong, Champassak (Houay Ho, Bolaven Distr.) and Attopeu provinces. In Vietnam: Lai Châu, Yên Bai, Hà Giang, Dac Lac, Son La, Lang Son, Cao Bang, Quang Ninh, Kon Tum, Khanh Hoa, Ninh Thuân, Lâm Dông (Dalat city), and Dông Nai provinces.

Habitat \& Ecology - Light demanding, frost-tolerant tree, can grow on well-drained, acid, mineral soils. Usually growing in pure stands or mixed with other species in conifer forests or with broad-leaved trees, preferring high rainfall, with distinct dry and rainy seasons, air humidity not too low. Altitude (800-) $1000-2300 \mathrm{~m}$. Young trees are slow-growing during the first five years, later rather fast-growing. 15 years after planting the resin can be extracted. Natural regeneration is good, especially in open areas. In Laos: flowering: February, March; fruiting: January to March the year after. In Vietnam: flowering: April, May; fruiting: the second year after flowering.

Uses - The soft and light wood is commonly used as timber, in housing implements and constructions, for boxes, matches, paper pulp, board-making, window or door frames, old- and slow-growing trees which develop red heartwood are chipped and used as torches sold in the local market, used for furniture, temporary electric poles, sometimes used as firewood. Resin good but not abundant, therefore not yet economically exploited.

Note - The diameter of the branches depends on the stand density, in open forest the diameter of branches is larger than that in dense forest.

Specimens examined: Averyanov et al. VH 162 (P); Capus 6 (P); Chevalier 38480 (P); Chinh 993 (P); Hayata 891 (P); Hennipman 3601 (L); Lecomte 1444, 1511, 1601 (P); Massie s.n. (P); Pételot 4383, 4385 (P); Poilane 1972, 2050, 3785, 3950, 4082, 4131, 15527, 15992, 16159, s.n.(P); Schmid 863, 864 (P); Spire $554(\mathrm{P})$.

\section{Pinus merkusii Jungh. \& de Vriese}

Synonyms - Pinus finlaysoniana Wall. ex Blume; P. latteri Mason; P. merkusiana Cooling \& Gaussen; P. merkusii var. tonkinensis (A. Chev.) Gaussen; P. sumatrana Jungh.; P. sylvestris auct. non L.

Vernacular names - Paek songbai, Paek yang, Khoua (L); Thông nhựa, Thông hai lá (V).

Big trees up to $50 \mathrm{~m}$ high, $60-80 \mathrm{~cm}$ diameter. Trunk straight, cylindrical, resinous. Bark thick, reddish when young, dark brown or blackish when old, deeply fissured longitudinally. Crown pyramidal with heavy horizontal branches. First year branches brownish, glabrous, without white powder. Foliage buds long and narrow with awlshaped scales. Needles in pairs of 2, 15-28 by $1 \mathrm{~mm}$, abruptly pointed, stomata on both surfaces, falling in the second year. Basal sheath 10-20 mm long, reddish. Male cones $18-25$ by $5 \mathrm{~mm}$. Female cones cylindrical before opening, $5-11$ by $3 \mathrm{~cm}$, usually falling soon after shedding seeds. Seeds ovate, slightly flat, 7.5 by $4.5 \mathrm{~mm}$, with a thin wing 25 by $8 \mathrm{~mm}$. 
Distribution - Scattered throughout South East Asia from East Myanmar to South China, Malaysia, Indonesia, Philippines. In Laos: Louang Namtha (Sing Distr.), Oudomsai (Hua Namkat Distr.), Houa Phan, Louang Prabang (Chomphet Distr.), Xieng Khouang, Bolikhamsai (Khamkeut Distr.), Khammouane (Nakai), Savannakhet, Saravane (Bolaven), Sekong, Champassak (Houay Ho Distr.), Attopeu provinces, and Vientiane Municipality (Phou Khao Khouay NBCA). In Vietnam: Lai Châu, Son La, Lang Son, Bac Thai, Hà Bac, Quang Ninh, Thanh Hoa, Nghê An (Vinh), Hà Tinh, Nam Hà, Thai-Nguyen, Khanh Hoa, Ninh Thuân, Dông Nai, Soc Trang, Quang Binh, Thua Thien Hue, Kon Tum, and Lâm Dông (Dalat city) provinces.

Habitat \& Ecology - Light demanding, heat- and drought-tolerant tree. Generally on poor quality acid soils over sandstone or fresh volcanic ash. Most stands show a clear relationship to fire or other disturbance. Occurs in pure stands or mixed with other species in conifer forest. Altitude 800-1200(-2000) $\mathrm{m}$. Young trees slow-growing during the first five years, later rather fast-growing. 15 years after planting the resin can be tapped from the trees. Natural regeneration is good, especially in open areas. In Laos and Vietnam after the Indochina war pure stands were growing in the bomb craters. In Laos: flowering: January, February; cones mature: February to May the year after. In Vietnam: flowering: May, June; cones mature: October, November the year after.

Uses - Pinewood is mainly used for house construction. Used for board-making, window or door frames, old trees are chipped fo $0, \mathrm{r}$ resinous wood used as torches, also for matches, paper pulp, furniture, pit props, electronic poles, ships and vehicle-building. High content of resin, each tree gives 3-4 $\mathrm{kg}$ of resin per year which is used for medicine, paints, printing, and in the perfume industry.

Specimens examined: D'Alleizette s.n. (P); Averyanov 2210 (P); Balansa 4204 (P); Beauchaine 107 (P); Bon 3162, s.n. (P); Capus 7 (P); Chevalier 29154, 29768, 29825, 30954, 37588, 37675, (P), 38231 (L); Fleury 37968, 38014 (P); Hiep 944 (P); Lecomte 1114, 1460 (P); Magnen 46 (P); Pierre 547 (P), s.n. (L); Poilane 2292, 2342, 5659, 6232, 8613, 12184, 15926 (P), 28632 (L, P); Service Forestier 38230, 38231 (P); Schmid 862 (P); Thorel 416 (P).

\section{PODOCARPACEAE}

Trees or shrubs, monoecious or dioecious, usually with straight trunk and more or less horizontal branches. Leaves simple, usually spirally arranged, sometimes opposite, alternate, scale-like, needle-like, linear to lanceolate, flat or leaf-like. Male cones axillary or terminal, solitary or in groups of 3-5. Stamens numerous, close together, imbricate, each with 2 sporangia, pollen grains usually winged. Female cones terminal or axillary, solitary or in fascicles; much reduced to a few fleshy bracts or scales, pendant, usually born on a thin peduncle, containing a single inverted ovule. Seeds wingless, completely covered by a fleshy structure referred to as an epimatium, epimatium and integument sometimes connate and forming a leathery testa. Cotyledons 2, with 2 parallel vascular bundles.

Distribution - In tropical and subtropical areas: 17 genera, 125 species. In Laos: c. 4 genera, c. 4 species. In Vietnam: c. 4 genera, c. 7 species. 


\section{KEY TO THE GENERA}

1a. Leaves dimorphic. Adult leaves needle- or scale-like, less than $5 \mathrm{~mm}$ long. Young

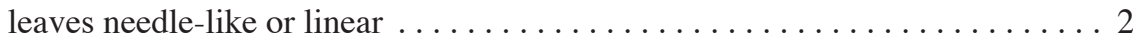

b. Leaves monomorphic. Adult leaves neither needle- nor scale-like, more than $5 \mathrm{~mm}$ long. Young leaves similar to adult leaves in shape, but often larger. . . 3

2a. Young leaves 2-ranked, linear. Adult leaves needle- or scale-like, falcate, $0.8-1.5$ cm long . . . . . . . Dacrycarpus

b. Young leaves not 2-ranked, spreading, linear to needle-like or subulate. Adult leaves hard and scale-like, $2-5 \mathrm{~mm}$ long. . . . . . . . . . . . . . . .

3a. Leaves with a single, obvious, often raised midvein visible on 1 or both surfaces 4. Podocarpus

b. Leaves without an obvious midvein but with many, parallel veins . . . 3. Nageia

\section{DACRYCARPUS (Endl.) de Laub.}

Dacrycarpus imbricatus (Blume) de Laub.

Synonyms - Podocarpus imbricatus Blume; P. kawaii Hayata

Vernacular names - Long len (L); Thông nàng, Thông lông gà, Bạnh tùng (V).

Trees up to $35 \mathrm{~m}$ high, up to $200 \mathrm{~cm}$ diam., bole straight, cylindrical. Bark dark brown or blackish, inner bark orange with brownish resin. Branchlets stiff, erect. Two types of leaves present, leaves on young branchlets and young trees linear, penniformly arranged, $0.6-1.5$ by $0.08-0.12 \mathrm{~cm}$, stomata arranged in 2 whitish rows on lower surface, base decurrent, margin entire, apex obliquely incurved apiculate, apiculus $0.2-0.3 \mathrm{~mm}$ long. Leaves on the old branches and fruiting branches, imbricate, scale-shaped, falcate, base keeled, apex acute, $1.5-2.5$ by $0.4-0.6 \mathrm{~mm}$. Male cones ovoid or ellipsoid, axillary, $0.6-1.2 \mathrm{~cm}$ long. Female cones solitary or paired at the tip of twigs, usually one fertile, receptacle glaucous, obovoid, $3-4$ by $1-2.5 \mathrm{~mm}$. Seeds globose, $5-6$ by $4-6$ $\mathrm{mm}$, reddish brown when ripe.

Distribution - India, Myanmar, China, Indochina, Thailand, Malaysia, Indonesia, Philippines, Papua New Guinea. In Laos: Xieng Khouang, Savannakhet, Saravane, and Attopeu provinces. In Vietnam: Tuyên Quang (Na Hang Distr.), Yên Bai, Lào Cai, Hà Bac, Hà Giang, Son La, Hoa Binh, Ninh Binh, Thanh Hoa, Nghê An, Hà Tinh, Kom Tum, Quang Binh, Quang Tri, Dac Lac, and Binh Thuân provinces.

Habitat \& Ecology - Found in tropical forests, altitude 300-1000 m, usually mixed with Altingia siamensis, Celtis australis, Cinnamomum spp., Gironniera subaequalis, Lithocarpus spp., and Mallotus yunnanensis. Light demanding tree, but shade tolerant when young, prefers fertile, humid and sandy soil. Natural regeneration is good.Cones: February to April; mature ones: October to December.

Uses - Wood with fine grain, resistant to termites and insects, easy to work. Used for construction, box making, cabinetwork, furniture, and fine art articles.

Specimens examined: Chevalier 29391, 29493 (P); Hiep et al. 403, 1437 (P); Krempe $1599(\mathrm{P})$; Pételot s.n. (P); Poilane 3462, 3521, 3539, 4397, 6500, 6527, 18742, 31056, 32545 (P). 
2. DACRYDIUM Sol. ex G. Forst.

Dacrydium elatum (Roxb.) Wall. ex Hook.

Synonyms - Dacrydium pierrei Hickel; Juniperus elata Roxb.

Vernacular names - Long len (L); Hoàng đàn giả, Dương tùng, Dương liễu, Bạnh tùng (V).

Trees up to $40 \mathrm{~m}$ high, up to $100 \mathrm{~cm}$ diam., bole straight. Crown a large billowy dome with tufts of more or less erect branches. Bark brown. Leaves dimorphic, spirally arranged. Young leaves and leaves on young trees awl-shaped, imbricate, $0.8-2 \mathrm{~cm}$ long. Leaves on twigs with cones scale-like and triangular, hard, base decurrent, apex often curved. Male cones solitary, terminal, cylindrical, 0.7-0.9 cm long. Female cones solitary or arranged in small groups, axillary or terminal, only one ovule develop. Seeds ovoid, $0.4-0.5$ by $0.2-0.3 \mathrm{~cm}$, suberect, $1 / 3$ of the base covered by epimatium.

Distribution - India, Myanmar, China, Indochina, Thailand, Malaysia, Indonesia, and Philippines. In Laos: Xieng Khouang, Savannakhet, Saravane, and Attopeu provinces. In Vietnam: Hà Bac, Hà Giang, Hà Tinh, Hoa Binh, Nghê An, Son La, Thanh Hoa, Tuyên Quang, Yên Bai, Kom Tum, Quang Binh, Quang Tri, Dac Lac, and Binh Thuân provinces.

Habitat \& Ecology - Found in tropical forests, altitude 700-2000 m, usually mixed with Castanopsis spp., Cupressus spp., Dacrycarpus imbricatus, and Fokienia hodginsii. Light demanding tree, prefers a cool climate, humid and yellow soil. Cones: February to April; mature ones: October, November.

Uses - Wood with fine grain, resistant to bending and pressing. Used for construction, boat and ship making, cabinet work, furniture, and fine art articles. Essential oil distilled from the wood is used as medicine, especially to treat stomach ache.

Specimens examined: Chevalier 29391, 29493 (P); Forestier 38217 (L); Hiep et al. 403, 1437 (P); Krempe 1599 (P); Pételot s.n.(P); Pierre 1396 (L); Poilane 3462, 3521, 3539, 4397, 6500, 6527, $18742,31056,32545(\mathrm{P})$.

\section{NAGEIA Gaertn.}

Nageia fleuryi (Hickel) de Laub.

Synonyms - Decussocarpus fleuryi (Hickel) de Laub.; Podocarpus fleuryi Hickel

Vernacular names - Kim giao, Kim giao núi, Báng súng (V).

Medium sized trees up to $20 \mathrm{~m}$ high, $80 \mathrm{~cm}$ diameter. Trunk straight. Crown pyramidal, branches horizontal or slightly pendulous. Bark greyish brown, peeling in large thin irregular shaped plates with scattered lenticels. Foliage buds a compact cluster of lanceolate deciduous scales abruptly wider than the shoot and distinctly acute. Twigs green. Leaves simple, opposite or subopposite, distichous, elliptic or broadly lanceolate, $8-20$ by $3-6 \mathrm{~cm}$, thick and leathery, base acute, margin entire, apex acute or acuminate, venation parallel. Petiole twisted, 5-10 mm long. Male cones cylindrical, solitary or in groups of 3-6, axillary, sessile, 2-3 cm long. Female cones solitary, axillary, ovules $1-3$, sessile in axils of subterminal bracts, only 1 ovule maturing; peduncles $1.5-2 \mathrm{~cm}$ long; mature cones globose, $1.5-2.5 \mathrm{~cm}$ diam., brownish violet, green when young. 
Distribution - South China and Indochina. In Laos: Vientiane province. In Vietnam: North and Central Vietnam, in Hai Phong (Cat Na NP), Ninh Binh (Cuc Phong NP), Thanh Hoa, and Nghê An provinces.

Habitat \& Ecology - Tropical forests, altitude 200-1000 m, usually mixed with Madhuca pasquieri, Quercus bambusaefolia, and Vatica odorata. Light-demanding tree, rather slow growing, natural regeneration very limited. Cones: March, April; mature ones: October, November.

Uses - Wood white with fine texture, resistant to termites and insects. Used for cabinetwork, furniture, fine art articles, and chopsticks. Leaves used as medicine to cure cough. The shape of the tree is beautiful, used as an ornamental in parks, along avenues and at pagodas and temples.

Note - Nageia fleuryi is an endangered tree species of Vietnam, depleted from its former numbers because of the demand for its timber. It should be strictly protected at Cat Ba and Cuc Phuong National Parks. It is listed (as Podocarpus fleuryi) as threatened species in Vietnam.

Specimens examined: Chevalier 37512 (P); Clemens 4190 (P); Fleury 38017 (P); Poilane 29808 (P); Tixier s.n. (P); Vidal 624 (P).

\section{PODOCARPUS L'Hér. ex Pers.}

\section{Podocarpus neriifolius D. Don - Fig. 2}

Synonyms - Nageia neriifolia (D. Don) Kuntze; Podocarpus annamensis N.E. Gray

Vernacular names - Ka dong (L); Thông tre, Thông trúc đào, Bạnh niên tùng, Thông tre nam (V).

Trees up to $35 \mathrm{~m}$ high, up to $100 \mathrm{~cm}$ diam., bole straight. Bark greyish brown, peeling off in longitudinally flakes. Branches spreading or ascending. Foliage bud scales erect, triangular, 1-1.5 mm wide, apex acute. Petiole 3-6 mm long. Leaves alternate, linear or lanceolate, usually slightly curved, $2.5-18$ by $0.5-1.5 \mathrm{~cm}$, leathery, midvein raised on beneath, flat or slightly raised on above, base wedge-shaped, apex long acuminate. Juvenile leaves wider, with obtuse to mucronate apex. Cones ovoid, $0.8-1.6 \mathrm{~cm}$ high. Male cones solitary or in clusters of 2-4, normally sessile, $2-4.5 \mathrm{~cm}$ long, with several spirally arranged, basal bracts. Female cones solitary, axillary, peduncle $0.4-2.2 \mathrm{~cm}$ long. Receptacle orange red when ripe, obconical ellipsoid, $4-10$ by $2-6 \mathrm{~mm}$, base with 2 subulate bracts, 2-6 mm long. Mature seed green to purple, outer layer fleshy to coriaceous, middle layer stony, and inner layer papyraceous.

Distribution - India, Nepal, Myanmar, Indochina, China, Thailand, Malaysia, Indonesia, Philippines, Papua New Guinea. In Laos: Houa Phan, Xieng Khouang, and Bolikhamsai provinces. In Vietnam: North and Central Vietnam, such as Hà Bac, Hà Giang, Hà Tinh, Hoa Binh, Lai Châu, Lào Cai, Nghê An, Son La, Thanh Hoa, Tuyên Quang, Kien Gian, and Yên Bai provinces.

Habitat \& Ecology - Found in tropical forests, altitude 400-1500 m, usually mixed with Castanopsis spp., Dacrycarpus imbricatus, Fokienia hodginsii, Lithocarpus spp., and Pometia species. Shape tolerant tree, prefers fertile, humid, and humus rich soil. Sometimes it regenerates by seed under dense forest cover. Cones: April, May; mature ones: August to November. 


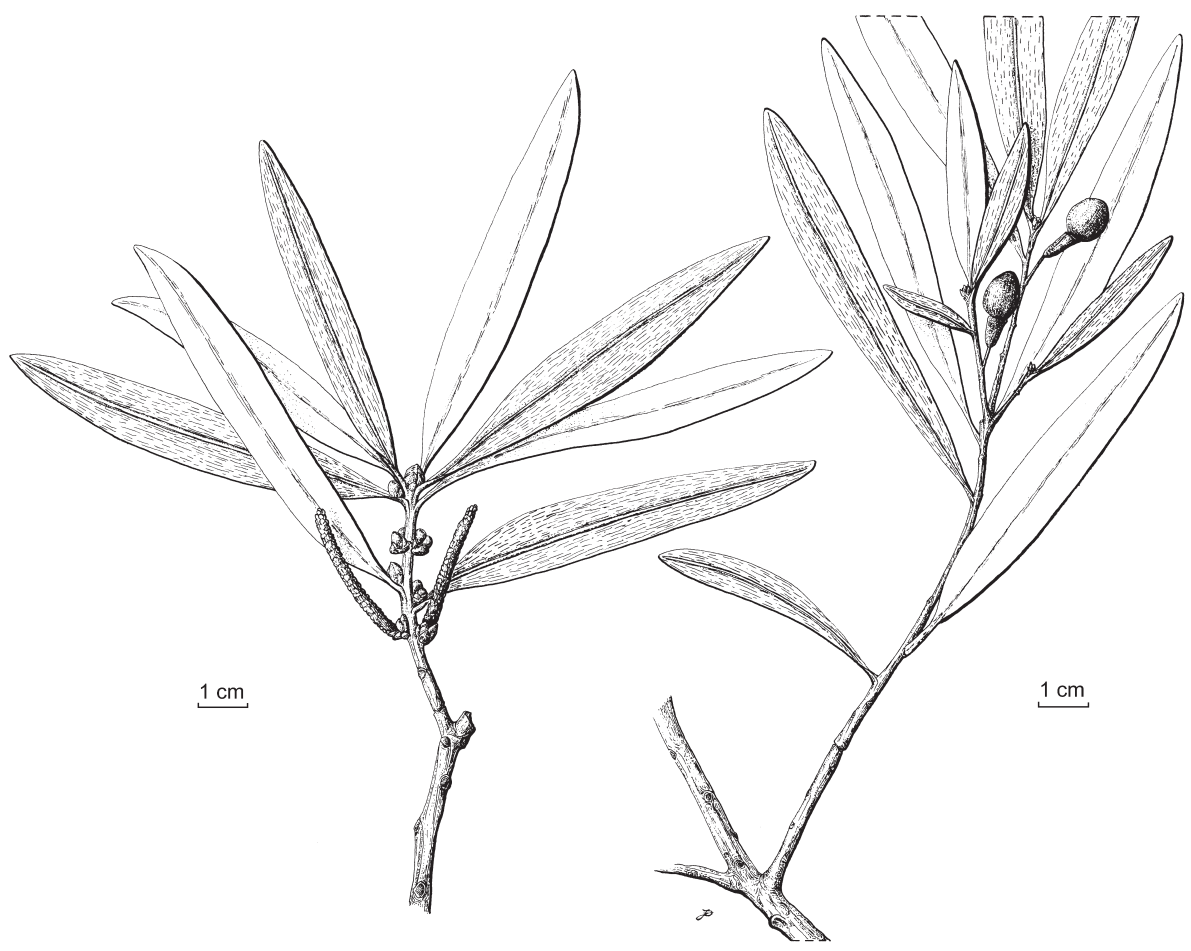

Fig. 2. Podocarpus neriifolius D. Don (Podocarpaceae).

Uses - Wood with fine texture, resistant to termites and insects. Used for construction, boat making, cabinetwork, furniture, and fine art articles. The shape of the tree is beautiful, used as an ornamental tree.

Specimens examined: Averyanov et al. 972 (P); Bodeneunc 36731 (P); Chevalier 36585, 38693, 39241 (P); Clemens 3475 (P); Evrard 336 (L, P), 1101, 2390 (P); Gray 48 (P); Pierre $354(\mathrm{P}), 5532$ (L, P); Poilane 1561, 3541, 6532, 21828, 24178, 24439, 29031, 32515, 32566, 35674 (P), 24443 , 30856, $30934(\mathrm{~L}, \mathrm{P})$.

\section{B. ANGIOSPERMAE}

\section{ALTINGIACEAE}

Trees or shrubs with aromatic resin in bark and wood. Buds often enclosed in scales. Stellate or tufted hairs or scales frequently present. Stipules present (except Rhodoleia). Leaves simple, alternate, spirally arranged, often palmately lobed, entire to serrate, venation pinnate or palmate. Flowers small, in small clusters, spikes or heads, bisexual, polygamous or unisexual, monoecious, rarely dioecious. Sepals and petals 4 or 5, latter often small or absent. Stamen(s) 1 or more, in 1 whorl. Ovary superior, half-inferior or inferior, carpels 2, often free at the apex, 2-locular, ovule(s) 1-many per locule. Styles 2, slender. Stigmas 2, apical or adaxially. Fruits forming globose 
heads, woody capsules, 2-4-valved, often tipped by persistent styles. Seed(s) 1-many, small, sometimes winged.

Distribution - Africa, Australia, but mainly in Asia: c. 28 genera, c. 130 species. In Laos: c. 6 genera, 6 species. In Vietnam: c. 7 genera, 16 species.

\section{KEY TO THE GENERA}

1a. Aromatic resin present or absent. Leaves elliptic or obovate, base usually obtuse, stellate hairs absent, venation pinnate. Male inflorescences in globose heads ....

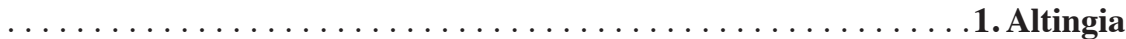

b. Aromatic resin always copious. Leaves 3-5-lobed, base cordate, stellately hairy when young, venation palmate. Male inflorescences in spikes . . 2. Liquidambar

\section{ALTINGIA Noroña}

Altingia siamensis Craib - Fig. 3

Synonyms - Altingia gracilipes Hemsl.; A. takhtajanii Thai

Vernacular names - Sop (L); Tô hạp, Tô hạp điện biên, Mạy xa hon (V).

Trees up to $45 \mathrm{~m}$ high, up to $1 \mathrm{~m}$ diameter. Trunk straight, cylindrical. Bark greyish pink, smooth, splitting into large pieces when old. Stipules caducous. Petioles slender, $2-3 \mathrm{~cm}$ long. Leaves simple, alternate,

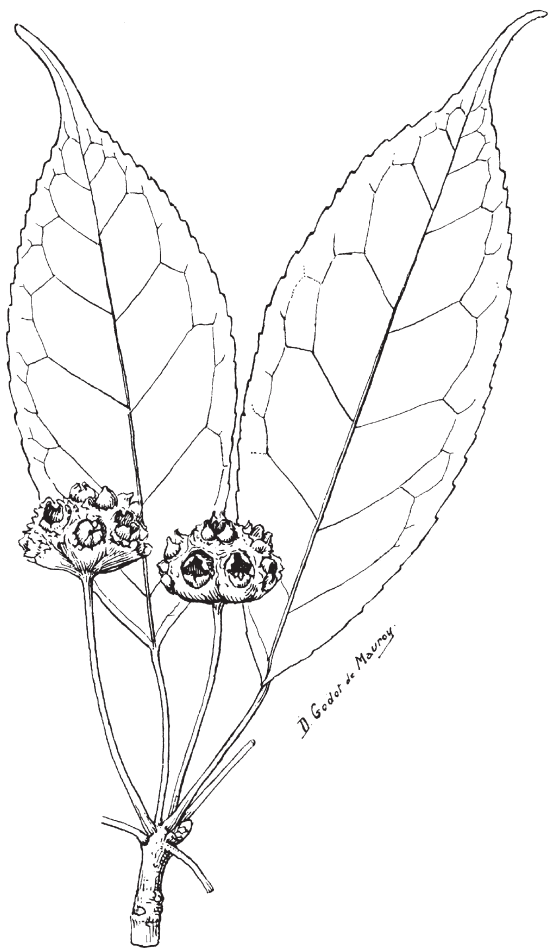
obovate, $5-8$ by $2-3 \mathrm{~cm}$, base obtuse, margin slightly roundish serrate, rarely entire, apex long pointed, venation pinnate, evident at lower surface, secondary veins 5-7 pairs. Leaves red when old. Flowers unisexual, monoecious. Male inflorescences in globose heads, sepals and petals absent, stamen 1, filaments short. Female flowers in globose heads, sepals scale-like, petals absent, ovary half inferior. Fruits forming globose heads, woody capsules, style persistent. Seed(s) very tiny, oblong, winged.

Distribution - India, Myanmar, Thailand, Indochina. In Laos: Vientiane province. In Vietnam: Lai Châu, Lào Cai, Son La, Gia Lai, Kon Tum, Dac Lac, and Ninh Thuân.

Fig. 3. Altingia siamensis Craib (Altingiaceae). 
Habitat \& Ecology - Primary and secondary forest, altitude below 700 m. Light demanding tree, growing very well in deep soils along streams. Usually mixed with Gironniera subaequalis, Machilus spp., Phoebe spp., and Quercus species. Natural regeneration is good at low forest cover, along streams. Flowering: February, March; fruiting: June to August.

Uses - Wood resistant to termites and insects. Used for construction, ship and boat building. Essential oil from resin is used in the perfume industry.

Note - Tardieu-Blot in Lecomte, Flore du Cambodge, du Laos et du Vietnam 4 (1965) 98-99 considered Altingia takhtajanensis Thai (= A. takhtajanii Thai) and Altingia siamensis Craib different species. Dung (1996) considered Altingia takhtajanii Thai a synonym of Altingia siamensis Craib. After examining the available specimens and literature we believe that Altingia takhtajanii Thai is indeed a synonym of Altingia siamensis Craib as no major differences can be found.

Specimens examined: Kerr 21255 (L, P); Maxwell 74886 (L); Phon 1147 (P); Pierre s.n.(P).

\section{LIQUIDAMBAR L.}

\section{Liquidambar formosana Hance - Fig. 4}

Synonyms - Liquidambar acerifolia Maxim.; L. maximoviczii Miq.; L. tonkinensis A. Chev.

Vernacular names - Sau sau (V), Chao, Cha phai (Mường, V).

Trees up to $40 \mathrm{~m}$ high, up to $1.5 \mathrm{~cm}$ diameter. Trunk straight, cylindrical. Bark blackish brown, thick, longitudinally fissured, aromatic resin copious. Twigs slender. Stipules nee-

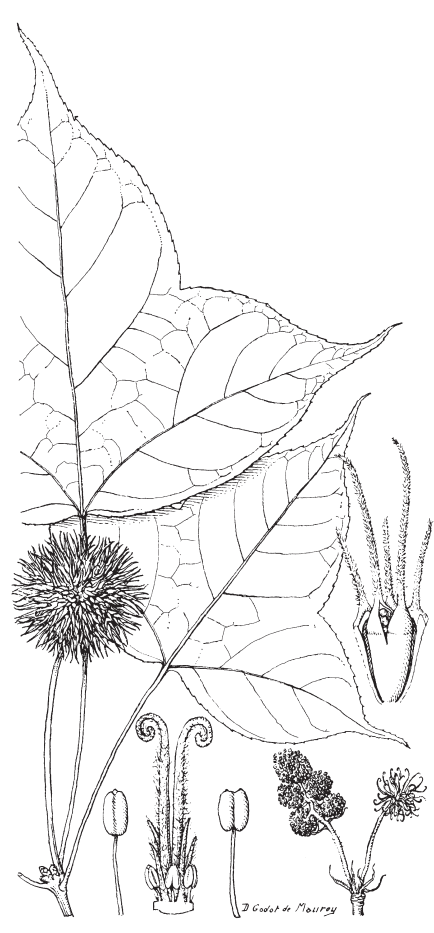
dle-shaped, 1-2 cm long, caducous. Petioles 8-10 $\mathrm{cm}$ long. Leaves simple, alternate, 3- or 5-lobed, usually 3-lobed, base cordate, margin serrulate, stellately hairy when young. Flowers unisexual, monoecious. Male flowers in spikes, sepals and petals absent, stamen 1. Female flowers in globose heads, sepals scale-like, petals absent, staminodes 4-10, ovary half inferior, 2-locular, ovules many per locule, styles 2, elongated, stigmas bifid. Fruits in globose heads, $2-3 \mathrm{~cm}$ diam., formed by many capsules, spiny from the persistent styles and calyx. Seed $(s)$ very tiny, winged.

Distribution - China and Vietnam. In Laos so far not yet recorded, but most probably present. In Vietnam widely distributed in the north, mainly in Hoa Binh, Hà Bac, Hà Tây, Bac Thai, Lang Son, Cao Bang, Quang Ninh, Ninh Binh, Thanh Hoa, and Nghê An provinces.

Fig. 4. Liquidambar formosana Hance (Altingiaceae). 
Habitat \& Ecology — Primary and secondary forest, altitude below $600 \mathrm{~m}$. Usually mixed with Canarium album, Engelhardtia chrysolepsis, and Erythrophloeum fordii. Shade tolerant when young, light demanding when mature, can grow on poor soils. Natural and coppice regeneration is very good. This species is a pioneer species after forest fire and in shifting cultivation areas. Flowering: March, April; fruiting: October to December.

Uses - Wood light, but strong after being processed. Used for construction, railway sleepers, boat- and ship-building, furniture. Resin used in production of perfume and medicine. Leaves used as vegetable.

Specimens examined: Balansa 1157 (P), 3170 (P); Bon 5118, 5394 (P); Boom 2406, 10755, 11885, 13166 (L); Butreau 35 (P); Cadays 38263 (P); Chevalier 29654, 30170, 37299, 40980 (P); Cuong 93 (L); Dodo s.n. (P); Domat 38201 (P); Faurie 45 (P); Pételot 5747 (L).

\section{ANACARDIACEAE}

Trees or shrubs, rarely climbers or epiphytic shrubs, usually with acid, often turpentine smell, sap becoming black when exposed to the air. Buttresses sometimes present. Bark smooth, cracked, fissured, scaly, flaky or dippled, sometimes blotched by black exudate. Inner bark pinkish or yellowish, turning black or brown. Sapwood whitish. Stipules absent. Petioles often thickened at the base. Leaves often crowded at the end of twigs, usually compound, often imparipinnate, less frequently simple or paripinnate, alternate, margin usually entire. Inflorescences mostly large, terminal or axillary panicles, rarely racemes or spike-like, bracts and bracteoles usually caducous, sometimes persistent. Flowers generally small, regular, bisexual or unisexual, then plants polygamous, monoecious or dioecious. Sepals 4 or 5 , free or connate. Petals absent or 4 or 5 , free, valvate or imbricate. Stamens 8-10-numerous, sometimes partly staminodal, inserted on the disc. Disc mostly well-developed. Ovary superior, 2-5(-12)-celled, rarely inferior, ovule 1 per cell, stigma(s) 1-5(-12)-lobed or entire; placentation axillary, but mostly seemingly parietal by abortion of locules. Fruit a drupe or nut, fleshy and resinous.

Distribution - Throughout the tropical regions of the world: c. 75 genera, 850 species. In Laos: c. 13 genera, c. 23 species. In Vietnam: c. 15 genera, c. 55 species.

\section{KEY TO THE GENERA}

1a. Bole not fluted, inner bark brown. Leaves without sour taste, domatia absent. Flowers dark red, polygamous. Seeds with 5 holes at the top . . . 1. Choerospondias

b. Bole often fluted, inner bark pink. Leaves with sour taste, domatia present. Flowers green-yellow or white, bisexual. Seeds without holes at the top. . . . . . . . .

2. Dracontomelon

\section{CHOEROSPONDIAS Burtt \& Hill}

\section{Choerospondias axillaris (Roxb.) Burtt \& Hill - Fig. 5}

Synonyms - Spondias acuminata Gamble; S. axillaris Roxb.; Poupartia fordii Hemsl.

Vernacular names - Mu (L); Xoan nhừ, Lát xoan, Xuyên cốc (V). 
Deciduous trees up to $20 \mathrm{~m}$ high, $30-40 \mathrm{~cm}$ diam., buttresses present. Bark grey-brown, cracked and peeling in vertical flakes, inner bark pink. Petioles $4-8 \mathrm{~mm}$ long, $4-7$ pairs of leaflets. Leaves spirally arranged, becoming red before falling, imparipinnately compound, alternate, $30-40 \mathrm{~cm}$ long, main stalk 5-12 cm long, grooved. Leaflets opposite, $4-12.5$ by $2-6 \mathrm{~cm}$, elliptic, base oblique, tips tapering, young leaves with scattered teeth, mature ones usually entire, venation pinnate, $6-16$ veins per side, domatia absent. Inflorescences panicles, flowers dark red, polygamous, male flowers in large branched clusters at the end of twigs, bisexual flowers in small groups, sepals connate, $2 \mathrm{~mm}$ long, 5-lobed, dark red glabrous outside, glandular-hairy inside, petals 5, pointed, glabrous, imbricate, stamens 10 , alternating with disc lobes, ovary superior, 5-celled. Fruit an ovoid or globose drupe, $1.5-2.5 \mathrm{~cm}$ diameter. Seeds with 5 holes at the top.

Distribution - India, China, Japan, Indochina. In Laos: Xieng Khouang and Houa Phan (Sam Nua Distr.) provinces. In Vietnam: from the north to Nghê An province in Central Vietnam.

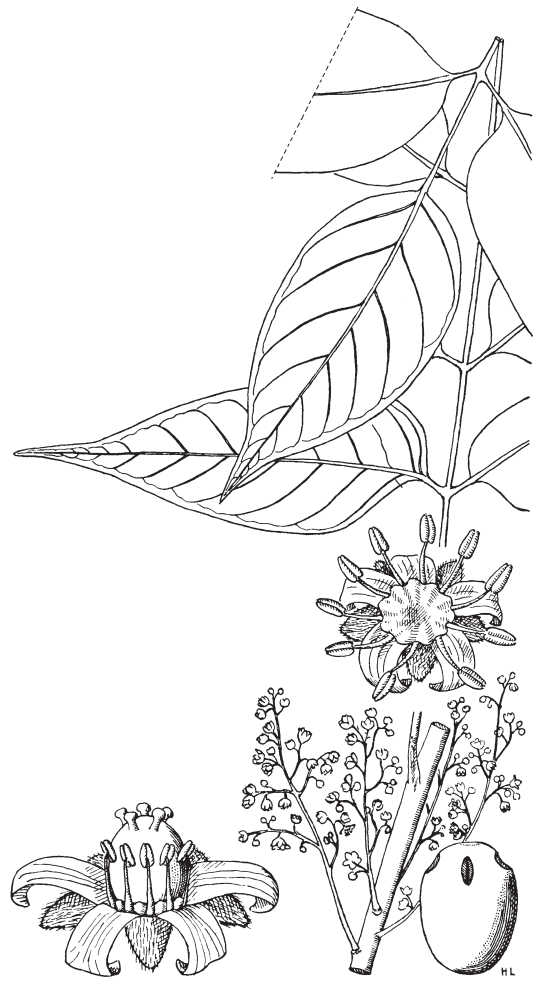

Fig. 5. Choerospondias axillaris (Roxb.) Burtt \& Hill (Anacardiaceae).

Habitat \& Ecology - A deciduous fast growing tree in secondary forests, altitude below $600 \mathrm{~m}$. This species occurs mainly on wet, deep soils or on heavy clay or sandy clay soils. Flowering: April to June; fruiting: July to September.

Uses - Wood soft, used for general furniture. Fruits edible, also used for wine production. Bark fibrous, can be used for making rope, the pericarp is used as medicine, to promote the flow of blood.

Specimens examined: Chevalier 29660 (P); Cuong 257 (L); Fleury 30155, 32537 (P); Hoi 412 (P); Pételot 5441 (P); Poilane 2083 (L, P); Smitinand 1740 (L); Soejarto et al. 11616 (L); Sukkri 32 (L); Tsang 29308 (P); Van Beusekom 440, 4325 (L).

\section{DRACONTOMELON Blume}

\section{Dracontomelon dao (Blanco) Merr. \& Rolfe - Fig. 6}

Synonyms - Dracontomelon duperreanum Pierre; D. mangiferum Blume; D. sinensis Stapf

Vernacular name - Sấu (V).

Large deciduous trees up to $35 \mathrm{~m}$ high, 1-1.2 m diam., usually with large buttresses. Bark grey brown, splitted into pieces, inner bark pink, latex absent, sometimes gum 
drops present. Twigs with large leaf scars, twigs, buds and bases of the leaf-stalks light fawn-brown, finely hairy. Leaves spirally arranged, imparipinnate compound, clustered near tips of twigs, more or less hairy, at least on the stalk and on the underside of the veins. Leaflets alternate or opposite, 4-9 pairs, leaf axis $30-50 \mathrm{~cm}$ long, main stalks $8-10 \mathrm{~cm}$ long, grooved at base; leaflets narrow oval with oblique bases, tapering apex, margin entire, apex acute, lower leaflets $5-9$ by $2-4 \mathrm{~cm}$, upper leaflets $10-15$ by $3-5$ $\mathrm{cm}$, venation pinnate, veins 7-14 pairs, usually with fulvous hairs at axils (domatia), upper surface glabrous or subglabrous, lower surface glabrous or pubescent, petiolules 3-4 mm long. Inflorescences a terminal or axillary panicle, up to $60 \mathrm{~cm}$ long, pubescent. Flowers minute, yellowish green or white, bisexual; sepals 5, fused at base, triangular, hairy outside but glabrous inside; petals 5, narrow and pointed, slightly longer than stamens and style, glabrous. Stamens 10, the ones opposite sepals longer than those opposite petals. Ovary superior, pubescent at base, 5-celled, styles 5. Fruit a globose

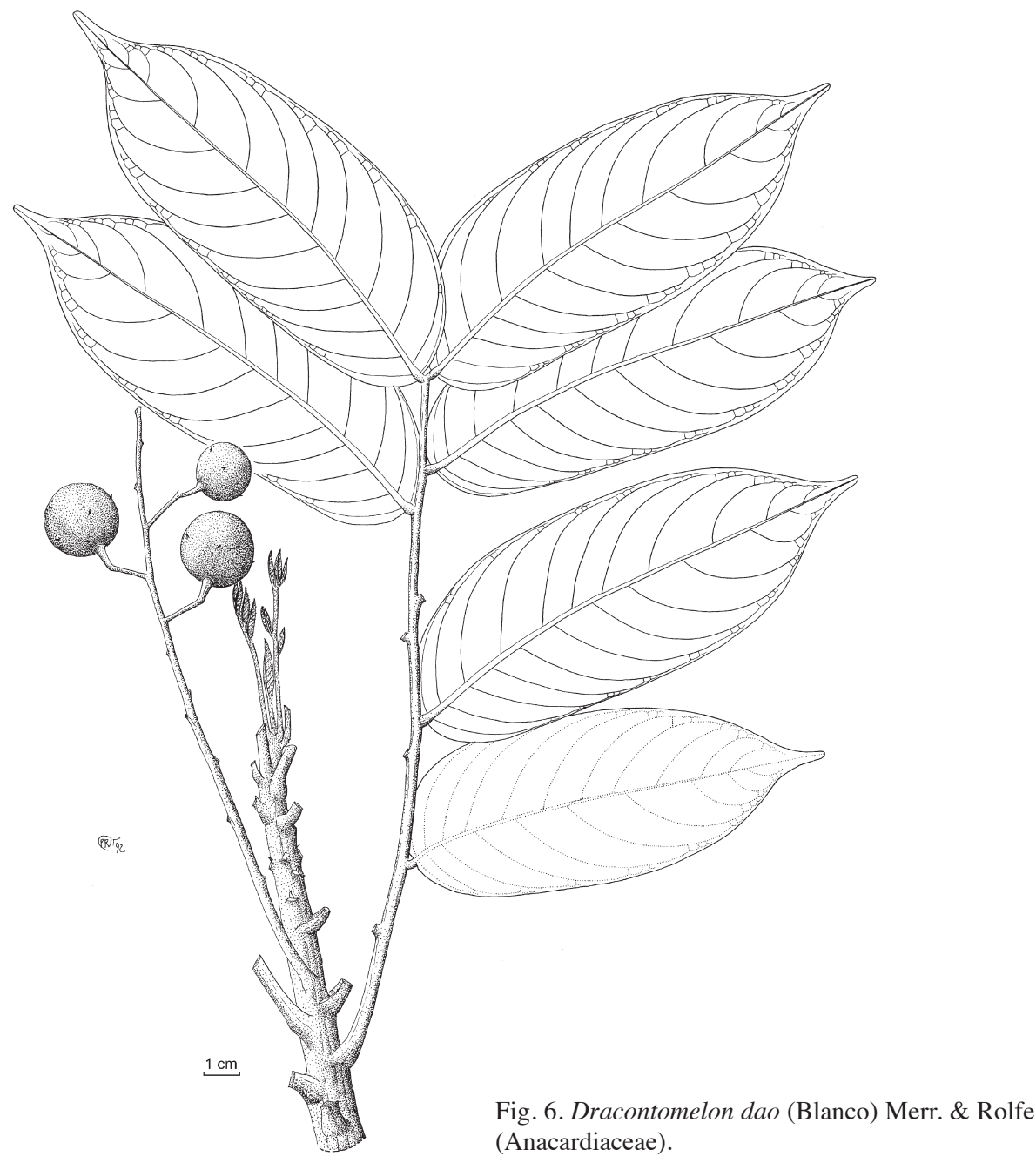


drupe, 2-4 cm diam., green turning yellowish, large with the 5-lobed calyx at the base. Stone very hard, flattened at the base.

Distribution - From India to the Solomon islands. This species occurs from North to Central Vietnam in Hà Tinh, Nghê An, Thanh Hoa, Kien Gian, Hoa Binh, Ninh Binh, Lang Son, and Hà Tây provinces.

Habitat \& Ecology - This species prefers wet and very light conditions in primary and secondary forests. In Vietnam it is often mixed with Aglaia gigantea and Parashorea chinensis. Flowering: April, May; mature fruits: June to September.

Uses - The wood is used for construction and making furniture. Leaves and fruit are used for cooking, mature fruits are edible and used for dental treatment.

Specimens examined: Balansa 3424, 3427, 3428, 4378, 4401, 4604 (P); Blanche 4339 (P); Chevalier 37292, 37296 (P), 38440 (L, P); Cuong 276 (L); Fleury 37973 (L, P); Forestier 38440 (P); Himavong 32 (L); Kerr 12110, 12802, 14196, 14834, 15663 (P); Pételot $3978(\mathrm{P})$; Pierre 1623 (P); Sangkhachand 1563 (L); Schmid 1156 (P); Smitinand 11017 (L); Soejarto et al. 10953 (L).

\section{ANNONACEAE}

Trees, shrubs, or climbers with aromatic tissues. Crown typically narrowly conical with a single main stem and horizontal twigs. Bark usually pale grey, buff-brown or orange-brown, smooth or elongate shallowly fissured; inner bark with conspicuous wedge-shaped fibre bundles. Twigs often hairy when young, and smooth when mature. Stipules absent. Leaves simple, alternate, often planar or drooping, margin entire, with short stalks. Flowers axillary or opposite the leaves or on old leafless stems, often pendulous. Sepals 3, valvate or imbricate, usually smaller than petals, pubescent or tomentose outside, glabrous inside. Petals 6 in 2 whorls, the inner whorl sometimes arching inwards and covering the sexual organs like a hood. Stamens minute, usually numerous, densely clustered in a central circular clump surrounding the ovaries. Ovaries usually many, free, pubescent, style present or absent. Monocarps fleshy, generally indehiscent, usually in clusters radiating from a common woody stalk. Seeds with ruminate endosperm.

Distribution - A large family found throughout the tropics: 130 genera, 2300 species. In Laos: c. 15 genera, 100 species. In Vietnam: c. 27 genera, 168 species.

\section{KEY TO THE GENERA}

1a. Leaves ovate-elliptic. Petals elliptic. Monocarps elliptic or obovoid, black when

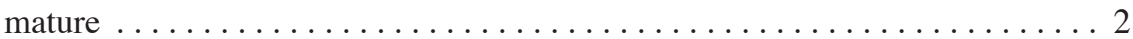

b. Leaves elliptic. Petals ovate. Monocarps round or ovoid, red when mature.....

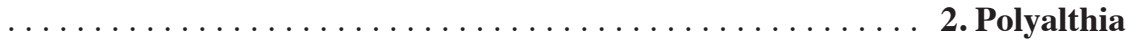

2a. Leave margins strongly wavy, base strongly asymmetric. Inner and outer whorls of petals spreading. Connective of stamens with a narrowly elliptic acute apex. Monocarps elliptic, symmetrical or slightly asymmetrical developed, stalks long

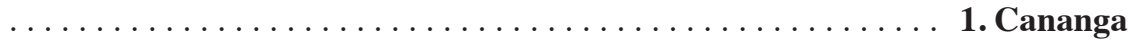

b. Leave margins flat or slightly wavy, base symmetric. Inner whorl of petals arching at base. Connective of stamens with a truncate dilate apex. Monocarps obovoid to cylindrical, strongly asymmetrical developed, stalks short. . . . . . 3. Xylopia 


\section{CANANGA Hook.f. \& Thomson}

Cananga odorata (Lam.) Hook.f. \& Thomson - Fig. 7

Basionym - Uvaria odorata Lam.

Vernacular names - Ka dan nga (L); Ngọc lan tây (V).

Evergreen medium unbuttressed trees up to $30 \mathrm{~m}$ high. Trunk straight. Bark grey or silvery, smooth. Young twigs minutely pubescent, becoming glabrous, dark, striate. Crown with branches drooping, or slightly erect with dangling leafy twigs. Leaves ovate to broadly elliptic, $5-20$ by $3-10 \mathrm{~cm}$, base rounded or heart-shaped, margin entire, but strongly wavy, apex acuminate, dark green above, green beneath, secondary veins 8 or 9 pairs, clearly visible on both sides, often with domatia, pubescent or glabrous on midrib and veins on both sides. Flowers hanging in clusters from the older branches, greenish turning light dull yellow, very fragrant. Sepals triangular. Petals elliptic, 5-9 by $0.5-1.5 \mathrm{~cm}$, with a purple or red spot at the base inside. Stamens many, connec-

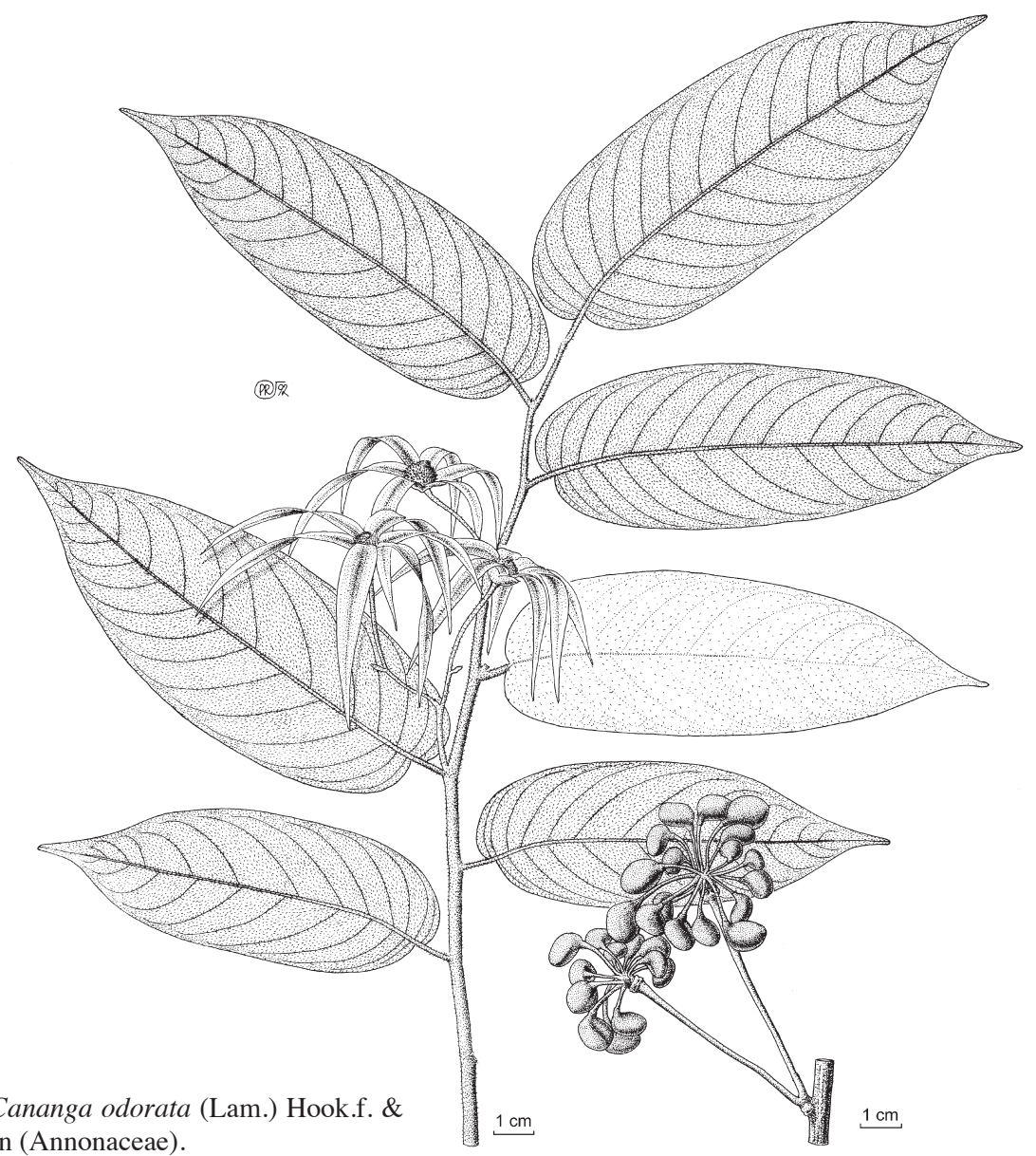

Fig. 7. Cananga odorata (Lam.) Hook.f. \& Thomson (Annonaceae) 
tive with a lanceolate acute apex. Carpels many, ovules many. Monocarps in clusters, symmetrical or slightly asymmetrical, elliptic in outline, $1.5-2.5$ by $1-1.5 \mathrm{~cm}$, green when young becoming blackish when mature, stalks c. $1.5 \mathrm{~cm}$ long, Seeds 2-12 in two rows, pale brown.

Distribution - Very widespread from India all over Malesia to Fiji. In Laos: Vientiane and Champassak provinces. In Vietnam: Hà Tây (Sonta, Mt Ba Vi), Hoa Binh, Hà Nôi, and Hô Chi Minh provinces.

Habitat \& Ecology - Common in secondary forest and on forest edges, abundant in villages where often dwarf forms are cultivated.

Uses - The plants are used for ornamental purposes and the flowers produce YlangYlang essential oil which is an important ingredient in the perfume industry.

Specimens examined: D'Alleizette 81 (L); Chevalier 29766, 37750,37801 (P); Counillon s.n.(P); Eberhardt 3426 (P); Germain 65 (P); Hiep 13 (P); Pierre 1744 (P); Poilane 27489 (P); Svengsuksa $32(\mathrm{P})$; Thorel 2126, $2136(\mathrm{P})$.

\section{POLYALTHIA Blume}

\section{Polyalthia cerasoides (Roxb.) Bedd.}

Vernacular names - Chan dong, Ka dan nga paa (L); Duôi trâu, Nhọc, Nhọc lá bé (V).

Medium deciduous trees up to $20 \mathrm{~m}$ high, 20-50 cm diameter. Trunk straight. Bark greyish or pale brown, inner bark yellow, aromatic. Young twigs slender and yellowish tomentose, old twigs glabrous. Leaves ovate, ovate-elliptic, $7-12$ by $5-6 \mathrm{~cm}$, base rounded or obtuse, margin slightly wavy, apex acuminate, secondary veins 7-9 pairs, glabrous above, pubescent beneath. Flower aromatic, solitary or in clusters of 2 or 3 flowers on short woody shoots, axillary, light green, stalks long and slender, 1.2-2.5 $\mathrm{cm}$, bracts 2 or 3. Sepals ovate or triangular, $0.6-0.9 \mathrm{~cm}$ long. Petals thick, ovate, the 3 outer petals 1.3 by $0.7 \mathrm{~cm}$, inner ones narrower and shorter. Stamens numerous, connective disc-like. Carpels many, tomentose, same length as stamens. Stigma headshaped, tomentose. Monocarps in clusters, fruitlet round or ovoid, 8 by $5 \mathrm{~mm}$, stalk long, young fruits green later yellow and red when mature, silky. Seed one.

Distribution - India, China, Indochina. In Laos: Louang Namtha, Sayabouri, Louang Prabang, Bolikhamsay, Saravane, Savannakhet, and Attopeu provinces. In Vietnam: Hoa Binh, Thanh Hoa, Ninh Thuân, Bac Giang, Nghê An, Hà Tinh, Gia Lai, Kon Tum, Dac Lac, Nhatrang, and Binh Thuân provinces.

Habitat \& Ecology - Tropical rain forest, in bushy savannah, edges of secondary forest, altitude below $700 \mathrm{~m}$, previously logged forest with an open canopy, and little disturbed closed canopy forest with Camellia, Lagerstroemia, and Liquidambar association. Flowering: January to March; fruiting: April to July.

Uses - Timber yellowish or greyish, annual rings obscure, texture fine, wood hard and heavy, usually splitting and curving when dry. Used in construction and for making agricultural tools. Used as traditional medicine.

Specimens examined: Averyanov 1024, 1038 (P); Fleury 38951 (L); Harmand 1169 (P); Pierre 469, 496, 1756 (P); Poilane 14, 140, 2779, 3195, 4854, 5588, 6034, 6064, 6090, 6256, 6356, 8537, 9808, 9849, 13721, 16627, 17406, 17809, 17863,26292, $26295(\mathrm{P})$; Soejarto et al. $11408(\mathrm{~L}) ;$ Thorel 3167 (P); Vichit Lamxay et al. 256 (L). 


\section{XYLOPIA L.}

\section{Xylopia vielana Pierre}

Vernacular names - Sa thang (L); Dền, Sai, Thối ruột $(\mathrm{V})$.

Medium, deciduous trees up to 20-25 m high, 20-30 cm diameter. Trunk straight, cylindrical. Bark dark orange, easily separated from wood, with many tough fibrous layers. Inner bark pale brown. Young twigs slender, green, covered with fulvous tomentose hairs. Petiole fulvous hairy, 5-8 $\mathrm{mm}$ long, Leaves broadly ovate, $6-10$ by $3-5$ $\mathrm{cm}$; base rounded, margins flat or slightly wavy, apex acuminate, secondary veins 7-12 pairs, evident beneath, both surfaces of leaves finely yellow hairy. Flowers solitary or in clusters with 1-3 flowers at axils of leaves near the end of twigs, flower buds pale green, yellow, aromatic. Sepals ovate or triangular, 4-5 mm long. Petals inner whorl arching at the base, outer whorl spreading, yellow tomentose outside. Stamens numerous in many whorls, connective with a truncate widely apex. Staminodes similar to fertile ones without anther sacs. Receptacle concave. Carpels few, tomentose. Monocarps in clusters, 4-6 fruitlets, obovoid to cylindrical, $3-4$ by $1-1.5 \mathrm{~cm}$, arranged on a globose receptacle, peduncle $1.5-3.5 \mathrm{~cm}$ long, strongly irregular, stalks short, green when young, slightly hairy, mature orange-yellow, black when dry, indehiscent. Seeds 2-5, black.

Distribution - India, Sri Lanka, China, Thailand, Indochina. In Laos: Vientiane, Bolikhamsay, and Champassak provinces. In Vietnam: Tuyên Quang, Bac Thai, Quang Ninh, Hà Bac, Hà Tây, Thanh Hoa, Nghê An, Dông Nai (Bien hoa city), Tây Ninh, and Khanh Hoa provinces.

Habitat \& Ecology - Tropical lowland rain forest, or secondary forest. Usually mixed with Acronychia laurina, Engelhardtia, and Ormosia balansae. Flowering: February to July; fruiting: April to November.

Uses - Timber slightly yellow, aromatic, used for common furniture, fuelwood, and mining poles. Bark and leaves used as tonic for the elderly and women after giving birth.

Specimens examined: D'Alleizette s.n.(P); Balansa 4165, 4169 (P); Eberhardt 4343 (P); Gourgand 4, 6, 8, 11 (P); Hahn s.n. (P); Harmand 646 (P); Muller 751 (P); Perry 2021 (P); Pierre 73, 205, 1759, 2020, 2021 (P); Pirey 41217 (P); Poilane 4638, 6866, 7454, 7773, 15157, 23620 (P); Soejarto et. al. 11410, 11451 (L); Thorel 2078 (P); Vidal 939, 4457 (P).

\section{APOCYNACEAE}

Small to large trees, climbers, rarely herbs, milksap present. Stipules absent. Leaves simple, mostly opposite, sometimes whorled, rarely spirally arranged. Inflorescence cymes or cymose panicles, rarely fasciculate or solitary, terminal or axillary. Flowers regular, rarely irregular, large, bisexual. Sepals tubular, often with colleters inside. Petals tubular, overlapping in bud. Stamens inserted on the corolla tube, completely included or exerted, anthers sagittate or ovate, free or adnate to the stigma, sometimes with the base and apex sterile. Disc present or absent. Ovary superior, rarely semi-inferior, with 2 separate carpels united into a common style, with one or two locules, pistil head-like. Fruits usually paired, a drupe, berry, capsule, or follicle. Seeds simple, aril absent, winged, with a ciliate margin or often with tuft of hairs at one or both ends. 
Distribution - Worldwide: c. 500 genera, c. 4500 species (incl. Asclepiadaceae). In Thailand: 36 genera, 118 species. In Laos: 30 genera, 65 species. In Vietnam: c. 36 genera, 109 species.

\section{KEY TO THE GENERA}

1a. Leaves whorled, 4-8, glabrous, secondary veins $20-45$ pairs, straight to the margin. Stamens inserted in upper half of corolla tube . . . . . . . . Alstonia

b. Leaves opposite, tomentose, secondary veins 8-15 pairs, curved to the margin. Stamens inserted at corolla mouth. . . . . . . . . . . . Wrightia

\section{ALSTONIA R.Br.}

\section{Alstonia scholaris (L.) R.Br. - Fig. 8}

Synonym - Echites scholaris L.

Vernacular names - Tin pet (L); Sưa, Mò cua (V).

Medium-sized to big deciduous trees 10-50(-60) $\mathrm{m}$ high, 20-80 cm diam.; trunk straight and often fluted at base. Bark smooth, scaly or shallowly fissured and peeling off in rectangular flakes, brown; inner bark granular, creamy, brown to yellow with white sap. Branches smooth or sparsely rough, scaly, with sparse or dense lenticels; branchlets terete, glabrous, grey-yellowish brown or sometimes dark brown, crown pagoda-shaped. Leaves in whorls of 4-8; petiole 5-20 mm long, glabrous, coriaceous, flattened and shallowly grooved above, slightly winged; colleters narrowly triangular and densely packed together in the axils; blade narrowly elliptic, obovate, 4.4-32 by $1.2-8.7 \mathrm{~cm}$, glossy and dark green above, pale or grey-green beneath, subcoriaceous when dry, base cuneate, apex acute, obtuse to rounded, or rarely retuse. Secondary veins $20-45(-55)$ pairs, straight and parallel to the margin, rarely close together or branched, forming an angle of $80-90^{\circ}$ with the midrib, venation reticulate, prominent above, glabrous. Inflorescences terminal cymes, many flowers in branched clusters (compound umbels) grouped at the end of twigs, 3-10 cm long, axes finely hairy; peduncle 1.5-6 $\mathrm{cm}$ long, glabrescent or pubescent; bracts and bracteoles scale-like, ovate or narrowly ovate, acuminate or sometimes trilobed or irregularly lobed at the apex, very shortly ciliate. Flowers fragrant; pedicel more or less $1 \mathrm{~mm}$ long. Sepals pale green, connate at the base, bell-shaped, with 5 teeth, ovate, $1-2.4$ by $0.8-2.5 \mathrm{~mm}$, apex acute to rounded, pubescent, ciliate. Petals white-yellow or cream, 5-lobed, overlapping to the left in bud, elliptic, $1.7-4.5$ by $2-4.5 \mathrm{~mm}$, tube $5.3-10 \mathrm{~mm}$ long; outside pubescent in the top of tube and lobes, inside pubescent except at the base of tube. Stamens 5 , inserted in upper half of corolla tube or below the mouth of the corolla tube, not projecting; filaments $0.5-0.7 \mathrm{~mm}$ long; anthers ovate, $0.9-1.2$ by $0.4-0.6 \mathrm{~mm}$, apex obtuse; disc very small and annular or absent. Ovary superior, ovoid or broadly ovoid, $0.9-1.5$ by $0.7-1 \mathrm{~mm}$, carpels 2, pubescent, style (incl. pistil head) 2.8-8 $\mathrm{mm}$ long. Fruit a pair of follicles, $20-56$ by $0.2-0.3 \mathrm{~cm}$, glabrous, splitting into 2 sections with many seeds. Seeds dark brown, elliptic, ends rounded, 3-7 by $1.5-2 \mathrm{~mm}$, margin slightly thickened. Tufts of cilia at both ends, longest cilia 8-18 mm long, becoming much shorter or glabrous towards the margins, hilum linear, 0.7-1 mm long. 


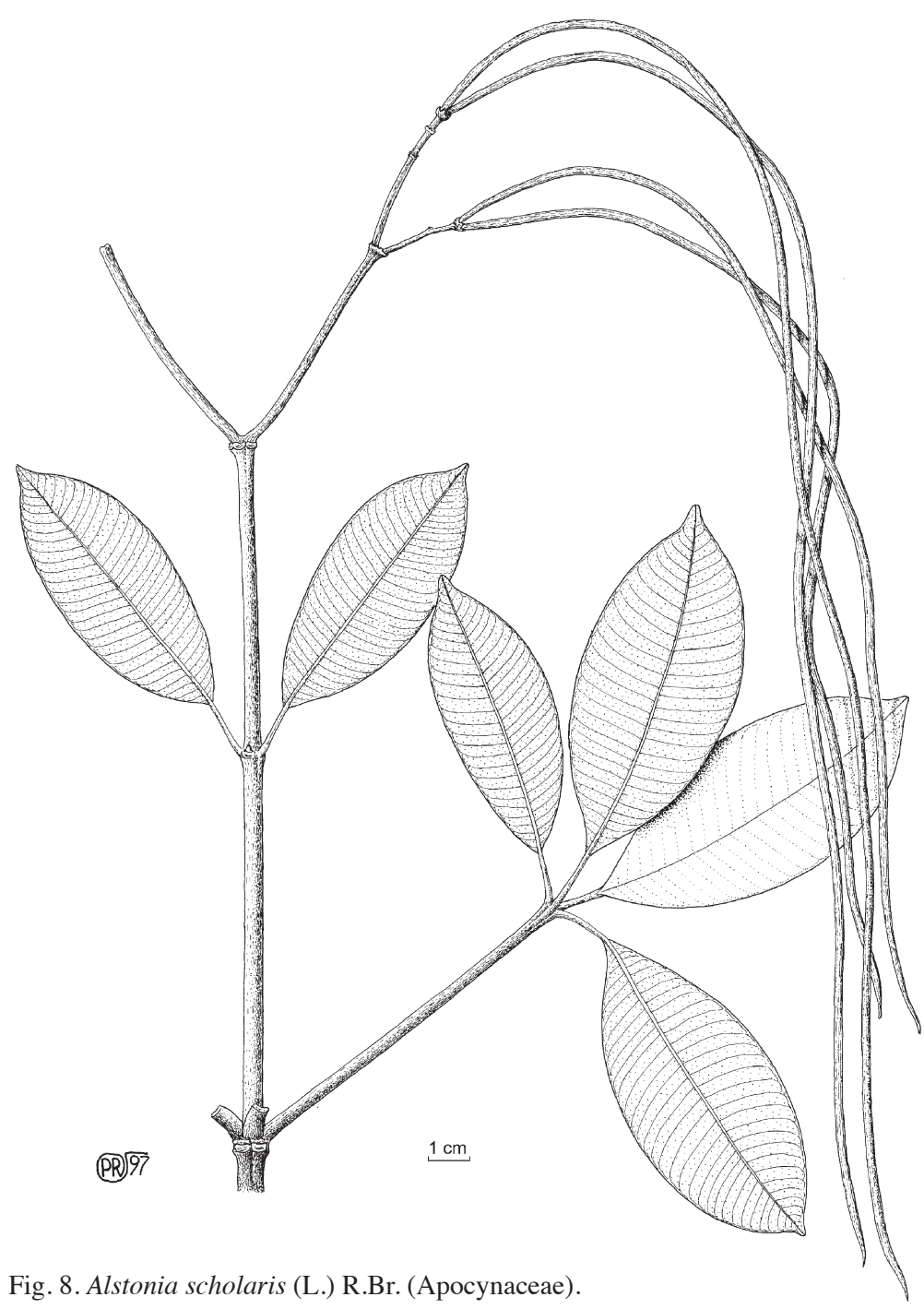

Distribution - Pakistan, India, Sri Lanka, Nepal, Bhutan, Bangladesh, Myanmar, China, Cambodia, Thailand, Malesia, Australia, Solomon Island. In Laos: Vientiane Municipality. In Vietnam: from north to south.

Habitat \& Ecology - In evergreen, deciduous or mixed forest, in scrub or at the edge of forest, on wet places, along streams or rivers, altitude 50-1200 m. Easily dispersed by seeds. Strong coppice-regeneration. Flowering: August to September; mature fruiting: January, February.

Uses - The bark is used to treat malaria and male genital pains. The sap can be applied to open sores to keep maggots out. The wood can be used as plywood, for boxes, coffins, frames, furniture, and handicrafts. Trees can be planted for ornamental purposes providing excellent shade. 
Specimens examined: Balansa 613, 4729 (P); Bon 6190 (P); Chevalier 36502 (P); Clemens 3869 (P); Cuong 905 (L); Donnat 38137 (P); Fleury 30177, 37764, 38009 (P); Lam 27 (P); Muller 725 (P); Pételot 5985 (P); Pierre 2093, 4410 (P); Poilane 771, 1223, 18859 (P); Spire 507 (P); Tsang $27098,27483(\mathrm{P})$.

\section{WRIGHTIA R.Br.}

\section{Wrightia pubescens $\mathrm{R}$.Br.}

Synonyms - Wrightia annamensis Eberh. \& Dubard; W. tomentosa Roem. \& Schult. var. cochinchinensis Pierre ex Pit.

Vernacular names - Mouk (L); Mức lông mềm, Thùng mực lông $(\mathrm{V})$.

Shrub or trees $10-20 \mathrm{~m}$ high, 50-60 cm diameter. Bark $3 \mathrm{~mm}$ thick, grey-white to grey-yellow, slightly rough, peeling off in thin pieces. Inner bark yellowish with much milky sap and soft and durable fibres. Branchlets cylindrical, tomentose; becoming glabrous and lenticellate. Petiole 3-8 mm long. Leaves opposite, usually with glands in the axils; blade papery to coriaceous, elliptic to obovate, $2.5-11.6$ by $1.4-5.2 \mathrm{~cm}$, base cuneate to obtuse, apex acuminate, secondary veins $8-15$ pairs, curved from midrib to the margin, densely tomentose or slightly pubescent. Inflorescences a terminal cyme, few- to many-flowered, 3-8 cm long; peduncle 1-2 cm long; tomentose or slightly pubescent. Bracts ovate, $2.5-3$ by $0.8-1 \mathrm{~mm}$. Flowers white, sometimes pinkish; pedicel 4.3-10 mm long. Bracteoles broadly ovate, 2 by $1.8 \mathrm{~mm}$. Sepals 5 , ovate, $1-3.5$ by $1.2-1.7 \mathrm{~mm}$, apex obtuse to acute, tomentose or slightly pubescent. Petals lobes overlapping to the left in bud, mature rotate, narrowly elliptic, 8.5-27.2 mm long, apex obtuse or rounded, tube 3-7 mm long, pubescent-papillose on lobes inside and outside, scales 10, linear, as long as stamens, the ones opposite sepals slightly shorter and forked. Stamens inserted at corolla mouth, filaments $0.7-1.8 \mathrm{~mm}$ long, anthers $6.2-7$ by $1.3-1.4 \mathrm{~mm}$, pubescent on both surfaces. Ovary superior, 1.6-2.1 $\mathrm{mm}$ long, glabrous, carpels medially connate, style (incl. pistil head) $8.5-10.2 \mathrm{~mm}$ long. Fruit connate follicles, cylindrical, $9.3-28$ by $0.9-1.7 \mathrm{~cm}$, splitting into two at dehiscence, minutely slightly pubescent or rarely glabrous. Seeds linear, $10.7-15.7$ by $1.1-2.6 \mathrm{~mm}$, with a tuft of hairs at tip, attached to the testa of the seed, $1.2-4.1 \mathrm{~cm}$ long.

Distribution - South China, Thailand, Cambodia, Malesia. In Laos: Champassak (Lakhone) provinces. In Vietnam: Vinh Phu, Nghê An, Khanh Hoa, Thanh Hoa, Gia Lai, Kon Tum, and Dac Lac provinces.

Habitat \& Ecology - Light demanding and drought-tolerant tree, in disturbed open area, on dry and poor degraded but prefers deep soil, altitude 280-800 m. Flowering: April to August; mature fruiting: August to February.

Uses - Wood is used for general construction, pencils, musical instruments, house appliances, windows, doors, and carving. The latex has been used against severe dysentery.

Specimens examined: Balansa 600, 2119, 2120,2121,2122 (P); Bon 1193, 1194, 1543, 1561,1566, 1568, 1814, 1815, 1816 (P); Chevalier 29624, 31403, 32064, 32117, 39495, 40954,41000 (P), 31403 (L); Cuong 1716 (P); Eberhardt 4345 (P); Evrard 1666 (P); Fleury 30172, 32080, 32117, 37620, 37728 (P); Harmand 694, 1149 (P); Hayata 245, 425 (P); Hiep 446, 514, 993 (P); Mouret 290 (P); Muller 1051 (P); Pételot 955, 958, 1411, 2446, 4917, 5988, 5991, 5994, 6003 (P); Phung Van Dieu 106 (P); Poilane 4992, 5315, 5584, 8773, 13006, 13323, 18544, 19792, 19932 (P); Spire 120, 570 (P); Thorel $696(\mathrm{P})$. 


\section{BETULACEAE}

Deciduous trees or shrubs. Pith triangular in cross section. Stipules present, usually early caducous. Leaves simple, alternate, petiolate. Margin usually doubly serrate, rarely simply serrate, lobed or entire, secondary veins pinnate, mostly with domatia in the axils of secondary veins with the midrib. Flowers unisexual. Male inflorescence precocious, elongate, pendulous. Bracts numerous, overlapping; each bract usually subtending a small cymose inflorescence with 1-3 flowers. Sepals scale-like. Petals absent. Stamens many, opposite sepals, filaments very short, connate or nearly so; anthers 2-loculed, opening by longitudinal slits. Female inflorescence pendulous or erect, with numerous overlapping bracts; each bract usually subtending a small cymose inflorescences with 2 or 3 flowers. Sepals 1-6 scale-like, or much reduced. Petals absent. Ovary inferior, 2-loculed, styles 2, free, ovule(s) 1 or 2, pendulous from near apex of each locule. Fruit a nut or nutlet, winged or not. Seed 1, with straight embryo and flat or thickened cotyledons, endosperm absent.

Distribution - Mainly in Asia, Europe, North and South America: 6 genera, c. 200 species. In Laos: 2 genera, 2 species. In Vietnam: c. 2 genera, 2 species.

\section{BETULA L.}

Betula alnoides Buch.-Ham.

Synonyms - Betula acuminata Wall.; Betulaster acuminata Spach

Vernacular names - Sakai (Xieng Khouang), Ketsana (Champassak, Bolaven) (L); Cáng lò (V).

Deciduous trees up to $30 \mathrm{~m}$ high, up to $60 \mathrm{~cm}$ diameter. Trunk straight and cylindrical, with rather open crown and slightly drooping branches. Young bark shiny brown, pelling in very thin horizontal flakes, medium-sizes trees with deeply fissured bark, rough and irregular flaking vertically when old, greyish or red-brown and easily rotting. Inner bark pale brown, contains oil, strongly aromatic. Petioles $0.6-1.3 \mathrm{~cm}$ long, slender. Leaves ovate $4-14$ by $2.5-5 \mathrm{~cm}$, base cuneate or nearly rounded, margin sharply and irregularly toothed, apex acuminate. Young leaves densely silvery hairy, mature leaves thin, smooth or with tufts of hairs (domatia) in the axils of secondary veins, lower surface with many tiny resinous dots, secondary veins 9-13 pairs. Flowers tiny, greenish, in drooping catkins along twigs or behind young leaves, male and female in different catkins but on same tree. Male flowers in slender catkins, up to 18 $\mathrm{cm}$ long, individual flowers in groups of 3 at the axil of a hairy bract. Sepals 4, linear, hairy. Stamens 4-6, with short filament, anthers 2. Female flowers in catkins, up to 9 $\mathrm{cm}$ long, thicker and denser, in groups of 2-5. Individual flowers solitary in the axil of a 3-lobed bract. Fruit a small nut, 1.5-4 mm long, with 2 thin wings 2 or 3 times broader than nut, clusters covered with spiky bracts that persists on a tree long after fruits have blown away by the wind.

Distribution - Subtropical forests of Nepal, India, Myanmar, South China, Thailand. In Laos: all northern provinces and in the southern provinces Saravane, Savannakhet (Se Pon), Champassak (Bolaven). In Vietnam: Tuyên Quang, Hà Giang, Lào Cai, Lang Son, Cao Bang, and Kon Tum provinces.

Habitat \& Ecology - Light demanding and fast-growing tree. Can be found in pure stands in secondary forests, in moist evergreen forests on rich and deep loamy soil, in 
dry evergreen hill forests on upper hill slopes and ridges on yellow-red soils. Mixed with Calophyllum, Canarium, Castanopsis, Machilus, Pinus, Quercus, and Tristaniopsis species. Altitude 300-2100 m. Natural regeneration on bare soil, even in erosion gullies, along roads and fallow forests. Flowering: usually October to February, rarely in July; fruiting: March to June.

Uses - Wood very hard and durable, used for house construction, household utensilmaking, fuel. Young bark used as additive for drinking water. The aromatic oil can be used in the leather industry.

Specimens examined: Averyanov et al. VH 142, VH 955 (P); Pocs \& Tiep 505 (P); Poilane 2072, $12163,15423,16162(\mathrm{P})$;

\section{BIGNONIACEAE}

Trees, shrubs, or lianas. Twigs often lenticellate and nodes with gland fields, spines very rare. Stipules absent, sometimes pseudostipules present (Markhamia). Leaves generally opposite, compound, 1-3 times pinnate, or in some cases simple and whorled or simple and spirally arranged, often with glands on the leaflets, margin entire to serrate, venation pinnate to palmate, domatia sometimes present. Inflorescences generally terminal, bracts present, cymose rarely racemose or even reduced to solitary flowers. Flowers bisexual, bilateral, usually large and showy, trumpet or funnel-shaped. Calyx tubular with or without 5 lobes or teeth, often closed in the bud and filled with water. Corolla zygomorphic, united basally to form a dorsiventrally flattened tube, with 5 lobes, 2 on the upper side, 3 on the lower. Stamens 4 or 5, mostly 4 and didynamous (2 long and 2 short) attached to the corolla. Ovary superior, 2-celled, stipe long, with 2-lobed stigma. Fruit a capsule, pod-like, but divided by a longitudinal partition into 2 compartments, splitting open when ripe. Seeds many, flat, winged or fringed with hairs, endosperm lacking.

Distribution - Widely distributed in tropical and subtropical regions: c. 120 genera, 650 species. In Laos: c. 9 genera, c. 15 species. In Vietnam: c. 8 genera, c. 22 species.

\section{KEY TO THE GENERA}

1a. Leaves imparipinnate, $25-55 \mathrm{~cm}$ long, the lowest pair of leaflets at the base of the petiole much smaller than the others and stipule-like (pseudostipules). Stamens 4, didynamous. Fruits $40-55 \mathrm{~cm}$ long, covered with fulvous hairs. Seeds with wings on both ends . . . . . . . . . . . . . . . . . . . . . . . . .

b. Leaves 2 or 3 times pinnate, up to $150 \mathrm{~cm}$ long, pseudostipules absent. Stamens 5 , equal or nearly equal. Fruits $40-120 \mathrm{~cm}$ long, glabrous. Seeds with a wing all

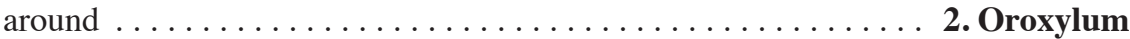

\section{MARKHAMIA Seem.}

Markhamia stipulata (Wall.) Seem. ex K. Schum.

Synonyms - Bignonia stipulata (Wall.) Roxb.; Markhamia indica P.H. Hô; Spathodea stipulata Wall.; S. velutina Kurz

Vernacular names - Khai (L); Đinh, Thiết đinh (V). 
Medium or large trees, $15-25 \mathrm{~m}$ high, $60-80 \mathrm{~cm}$ diameter. Twigs densely covered with caducous fulvous hairs. Bark grey-yellow, thin, slightly fissured, inner bark consisting of alternate pale orange and dark orange layers. Petioles $4-12 \mathrm{~cm}$ long. Leaves imparipinnate, $25-55 \mathrm{~cm}$ long, petiolules very short $0-3 \mathrm{~mm}$ long; leaflets elliptic, 5-9 pairs, $8-20$ by $3-7 \mathrm{~cm}$, base rounded or obtuse, margin entire or denticulate, apex acuminate or attenuate, lower surface of mature leaflets with pale brown hairs, the lowest pair of sessile leaflets at the base of petiole much smaller than others and stipule-like. Inflorescence a raceme. Flowers 7-12 cm long, cream or brownish yellow. Calyx 3-5.5 cm long, deeply split on one side only, curved sharply backwards at the top, without lobes or teeth. Corolla broadly funnel-shaped large, wart-like glands outside. Stamens 4, didynamous, filaments brownish violet. Fruit flat $40-70 \mathrm{~cm}$ long, $3-4.5 \mathrm{~cm}$ wide, covered with fulvous hairs. Seeds $3-5 \mathrm{~cm}$ long, rectangular with thin semi-transparent wings on both ends.

Distribution - In Laos: Louang Prabang, Vientiane, and Savannakhet provinces. In Vietnam: from North to South Vietnam, Kien Gian, Hoa Binh, Hà Tây, Thanh Hoa, Nghê An, Quang Binh, Quang Tri, Phu Yên, and Khanh Hoa provinces, but concentrated in Tuyên Quang and Lang Son provinces.

Habitat \& Ecology - Growing in evergreen forest on limestone mountains, mixed with Aglaia gigantea, Cinnamomum obtusiflorum, and Dracontomelon dao. Flowering: October to January next year; fruiting: February to May.

Uses - The wood is hard and heavy and resistant to insects, especially termites; used for valuable furniture and construction. Young shoots are sold on local markets in Laos as vegetable.

Note - Santisuk \& Vidal, Flore du Cambodge, du Laos et du Vietnam 22 (1985) 52 considered Markhamia cauda-felina (Hance) Sprague a synonym of Markhamia stipulata var. kerrii Sprague. We think that Markhamia cauda-felina is a good species, differing from $M$. stipulata in being a small tree, never reaching more than $15 \mathrm{~m}$ high, with much longer petiolules and with much longer fruits.

Specimens examined: Bejaud 95 (L); Bon 4702, 5218, 5407 (L); Fleury 30911 (L); Hiep 311 (L); Kostermans 355 (L); Larsen 8791 (L); Linh Gioc 13 (L); Muller 199 (L); Pételot 330 (L); Poilane 25003, 28050 (L); Soejarto 5870 (L).

\section{OROXYLUM Vent.}

\section{Oroxylum indicum (L.) Kurz - Fig. 9}

Synonyms - Bignonia indica L.; B. pentandra Lour.; Calosanthes indica (L.) Blume; Spathodea indica (L.) Pers.

Vernacular names - Lin maiz (L), Ing ka (Xieng Khouang, L); Núc nác (V), Tonok (Gia Lai, Kom Tum, V).

Evergreen or partly deciduous trees up to $18 \mathrm{~m}$ high. Young trees with a single main stem with the leaves clustered at the top like in most palms. Bark pale creamy brown or pale grey, twigs very stout, pale grey, with large scars. Leaves up to $150 \mathrm{~cm}$ long, 2 or 3 times pinnate with terminal leaflets, swollen at the nodes of main and lateral rhachis. Petiolules 5-20 mm long. Leaflets 5-20 mm long, broadly elliptic, 6-15 by 4-9 $\mathrm{cm}$, base rounded or cuneate, margin entire, apex acuminate or pointed. Inflorescences in 


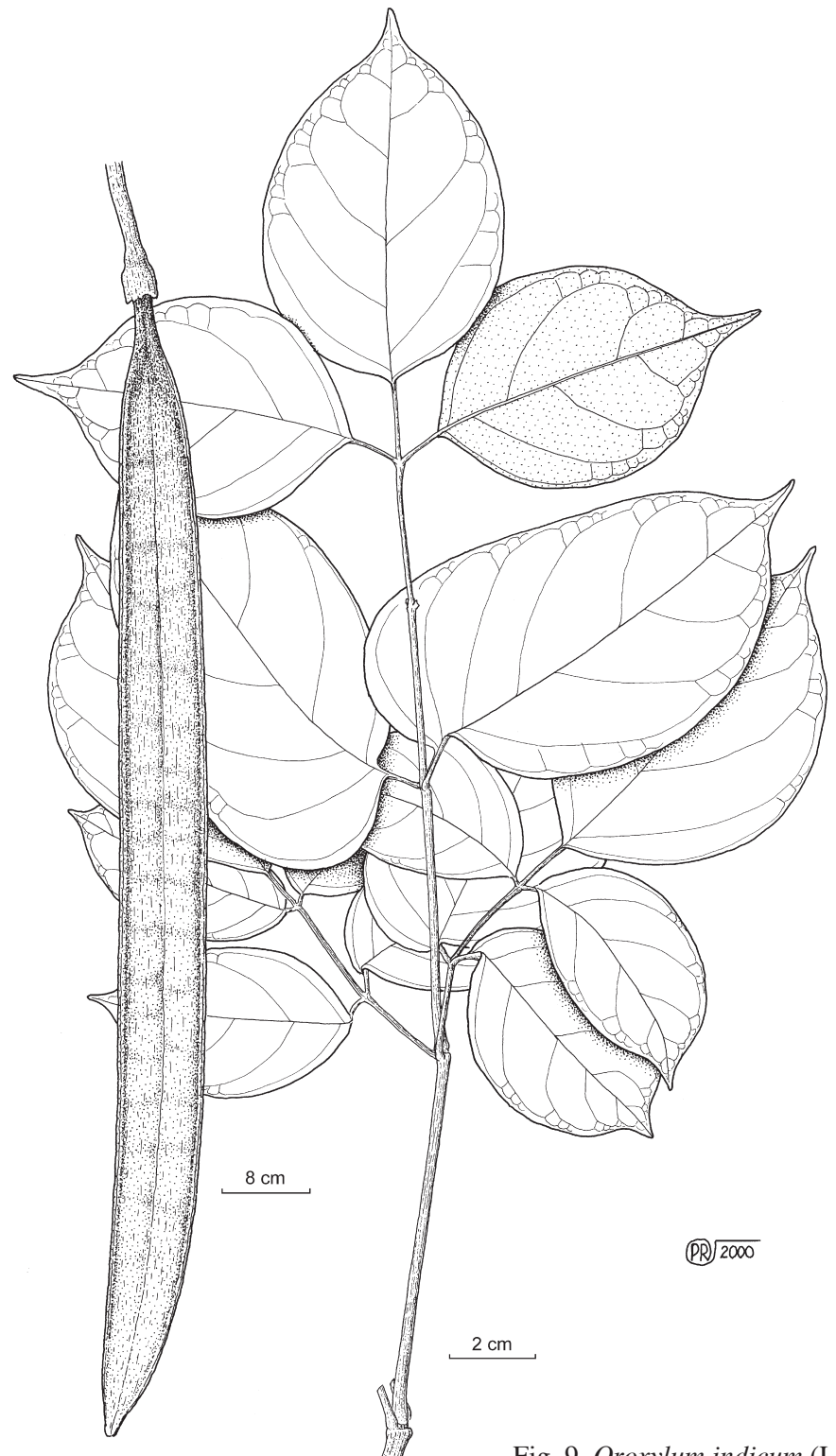

Fig. 9. Oroxylum indicum (L.) Kurz (Bignonicaceae).

terminal racemes, $60-18 \mathrm{~cm}$ long. Flowers large with a foxy stink. Calyx tubular, 2.5 -4 $\mathrm{cm}$ long, without lobes, filled with water in bud. Corolla funnel-shaped, with 5 lobes, c. $13.5 \mathrm{~cm}$ long, c. $12 \mathrm{~cm}$ wide, fleshy, lurid reddish purple to liver brown outside, greenish white and pinkish yellow inside, lobes wrinkled. Stamens 5, equal or nearly equal, hairy at base. Fruits 40-120 cm long, dark brown, flattened, slightly curved at base, with a fine ridge on each side, woody, splitting into 2 sections lengthwise. Seeds many, $4-8$ by $3-5 \mathrm{~cm}$, with a thin, semi-transparent wing all around. 
Distribution - India, China, Indochina, Malaysia.Very common in Laos and Vietnam.

Habitat \& Ecology - A fast growing species, found along the forest fringes, roadsides, and planted around the houses in midland regions. Prefers deep, wet, and well-drained soil. Usually mixed with Alangium kurzii and Gironniera subaequalis. Flowering: April to August; fruiting: October to December.

Uses - Wood soft, can be used for making matches, firewood, and for paper as the fibres are long. Young fruits edible. Seeds used to cure stomachache, lasting cough, pleuro-pneumonia and pimples. The bark is rich in tannin.

Specimens examined: Balansa 800 (P); Bon 1728 (P); Chevalier 8595, 19587, 38197 (L); Domat 38197 (P); Dournes s.n. (P); Dupuy 201 (P); Dussaud 77 (P); Fleury 30134 (P); Geesink et al. 6077 (L); Hahn 1297 (P); Kostermans 94, 1456 (L); Larsen et al. 2304 (L); Massie s.n. (P); Palee 44 (L); Pierre 232 (P); Poilane 661, 1808, 10015 (P), 8595, 19587 (L, P); Pottier 223 (P); Soejarto et al. 5886, 10544, $11528(\mathrm{~L})$; Thorel $1130(\mathrm{P})$; Vidal $916(\mathrm{P})$; Welzen $33(\mathrm{~L})$.

\section{BOMBACACEAE}

Trees, trunk straight, usually with buttresses at base and large spreading crown. Bark with sharp conical thorns. Stipules present, early caducous. Leaves alternate, simple or digitately compound, usually with scales. Inflorescences terminal or axillary racemes, cymose, fasciculate or solitary. Flowers large and showy, bisexual. Sepals cup-shaped, apex irregularly 3-5-lobed, lobes not overlapping. Petals large, free, overlapping. Stamens long, many, filaments are united in bundles or in a tube (monodelphous) or arranged into five groups or clusters (pentadelphous), anthers reniform. Ovary superior, 2-5 locules, ovules 2 to many in each locule. Fruits a big woody capsule, smooth, usually splitting into 5 parts filled with fluffy silky hairs. Seeds ovoid, or round, glabrous or enclosed by wool.

Distribution - Worldwide, mainly in tropical America: c. 20 genera, 250 species. Laos: 1 genus, 1 species. Vietnam: c. 2 genera, 6 species.

\section{BOMBAX L.}

\section{Bombax ceiba L.}

Synonyms - Bombax malabaricum DC.; B. thorelii Gagnep.

Vernacular names - Ngiu pa, Ngiu deng (L); Gạo, Mộc miên (V).

Large, deciduous trees up to $35 \mathrm{~m}$ high, up to $340 \mathrm{~cm}$ diameter. Trunk straight, buttresses prominent and large at the base when old. Bark pale grey or cream, studded with sharp conical thorns when young, smooth when old. In young trees the lateral branches are horizontal and straight. Crown large and lax. Stipules minute. Petiole 10-20 cm long. Leaves digitately compound, alternate, petiole $10-19 \mathrm{~cm}$ long. Petiolule $1.5-2.5 \mathrm{~cm}$ long. Leaflets $5-7$, ovate, or narrowly elliptic, $8-15$ by $4-5 \mathrm{~cm}$, base broad or tapering, margin entire, apex acuminate, glabrous, secondary veins $9-15$ pairs. Flowers bright orange-red, solitary or fasciculate, 1-3 flowers on a twig, 8-12 cm long, appearing after the old leaves fall. Pedicel 1-2 cm long, thick, glabrous or puberulous. Calyx 5, bright green, 1.5-3 cm long, glabrous outside, tomentose inside. Petals 5, red or 
orange red, thick and fleshy, spreading, obovate, $8-10$ by $3-4 \mathrm{~cm}$, tomentose on both sides. Stamens pale orange, many, in two whorls, fused together into 10 bundles, anthers, attached in the middle of the lower surface (peltate). Ovary conical, style slender, dark red, spreading, longer than stamens, stigma with 5 short branches. Fruit a woody capsule, elliptic, $8-17$ by $4-6 \mathrm{~cm}$, opening longitudinally into 5 segments, inner walls covered with silky cotton-like hairs. Seeds numerous, ovoid, glossy, with silky cotton-like hairs.

Distribution - India, South China, Thailand, Cambodia, Malaysia, Indonesia. In Laos: along the Mekong. In Vietnam: Tây Ninh province.

Habitat \& Ecology - In natural forests, altitude up to $800 \mathrm{~m}$, or planted in all parts of the countries. Suitable for growing on deep, dry, sandy soil. The species grows very fast. Can be propagated by seedlings or by stumps. Resistant to slight frost, not affected by drought and not killed by fires. Flowering: February to April; fruiting: May to July.

Uses - Wood is used for timber, plywood, common implement-making as boxes, matchsticks, sawing boards, wooden shoes, coffins, and firewood. The floss is used as stuffing in cushions, mats, and pillows. Inner bark yields good fibres, suitable for cordage. The tree is planted as an ornamental.

Note - We have seen only two specimens from Laos and Vietnam available at the Paris Herbarium. The description is mainly based on specimens from Thailand and Sri Lanka. - Gagnepain, Fl. Gen. Indochine (1910) 397 recognizes two species, i.e. $B$. malabaricum and $B$. thorelii. After studying the type material of both we decided to unite them with $B$. ceiba as there are no major differences.

Specimens examined: Maxwell 88-108(L); Muller 732 (P); Robyns 7189, 7190, 7316, 7326, 7332 (P); Thorel 3003, s.n. (P).

\section{BURSERACEAE}

Medium to large buttressed trees, rarely shrubs, crushed living parts with strong resinous smell. Bark pale grey to brown, smooth or scaly, often lenticellate, surface sometimes with brown, black, or white resin patches; inner bark usually pinkish, laminated or mottled with droplets of clear or white resinous gum, with strong resinous smell in most species (especially those of Canarium and Triomma). Sapwood often white, shiny, sometimes pinkish or pale yellowish brown, vessels usually visible with the naked eyes. (Pseudo)stipules present in all species of Garuga and in most species of Canarium. Leaves compound, usually imparipinnate, rarely simple. Leaflets margin entire, except in some Canarium and Garuga species. Leaves and leaflets distinctly stalked, the stalks kneed at both ends, the leaf-stalk swollen at the nodes even when dry. Inflorescences panicles, sometimes racemes, thyrses or spikes, axillary or terminal. Flowers bisexual, unisexual, or polygamous, dioecious, 3- or 5-merous, usually greenish to cream or white, the remains of the other sex persisting, sepals valvate, mostly united, petals valvate, free, stamens usually twice as many as petals, filaments free or united, sometimes fused to the disc, anthers elongate, dehiscing inwards. Disc present, inside stamens (except in Triomma). Ovary superior, with 3-5 cells, each with 2 descending ovules, style simple, stigma globular often slightly lobed. Fruit a drupe with a fleshy to leathery resinous wall and a more or less woody stone, or in Triomma a woody capsule. 
Stone 3-celled or less by reduction. Seed one, with fleshy cotyledons, containing oil, endosperm absent. Cotyledons emerging from the ground on germination.

Distribution - Throughout tropics and subtropics: 16 genera, 550 species. In Laos: so far not yet recorded. In Vietnam: c. 4 genera, c.13 species.

\section{CANARIUM L.}

\section{KEY TO THE SPECIES}

1a. Slash of the bark with white sticky sap. Stipules present. Inflorescences shorter than the leaves, flowers polygamous. Fruits yellowish green when ripe, stone with

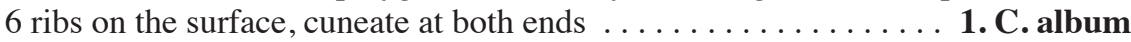

b. Slash of the bark with black sap. Stipules absent. Inflorescences longer than the leaves, flowers unisexual. Fruits dark violet when ripe, stone with smooth surface, rounded at both ends $\ldots \ldots \ldots \ldots \ldots \ldots \ldots \ldots \ldots \ldots \ldots \ldots \ldots \ldots \ldots$. . pimela

\section{Canarium album (Lour.) Raeusch.}

Synonym - Canarium tonkinensis Engl.

Vernacular name - Trám trắng $(\mathrm{V})$.

Large trees up to $30 \mathrm{~m}$ high, $80 \mathrm{~cm}$ diameter. Trunk cylindrical. Bark light brown, fissured with many lenticels. Outer bark thin, inner bark pinkish brown, laminated, aromatic with white sticky sap. Stipules awl-shaped, caducous. Petioles 5-8 cm long, swollen at base. Leaves imparipinnately compound. Leaflets opposite, 4-8 pairs, elliptic, $6-15$ by $2.5-6 \mathrm{~cm}$, crustaceous, with many shining white scales beneath, base slightly oblique, margin entire, apex distinctly acuminate, petiolules 5-10 mm long, basal pair of leaflets usually smaller. Inflorescences panicles, usually shorter than the leaves. Flowers polygamous. Pedicles 2-7 mm long. Calyx cupular, lobes deltoid, outside hairy or glabrous, inside densely silky-hairy. Petals 3 , cream-white, free, usually overlapping in bud, outside hairy in centre, inside usually glabrous. Stamens 6 , in one whorl, free, united at base, filaments flattened. Disc within the stamens, 6-lobed, strongly developed in bisexual flowers. Ovary ovoid, 3-celled. Fruit an oblong drupe, $3.5-4$ by $2-2.5 \mathrm{~cm}$, round at both ends, yellowish green when ripe; calyx persistent in fruit. Stone hard, woody, with 6 ribs on the surface, cuneate at both ends, 3-celled. Seed one per cell.

Distribution - China, Japan, Vietnam, Malaysia. In Vietnam: most provinces, particularly in Tuyên Quang, Quang Ninh, Bac Thai, Kien Gian, Vinh Phu, and Thanh Hoa.

Habitat \& Ecology - Distributed in primary and secondary forest, altitude below $500 \mathrm{~m}$. Usually mixed with Erythrophloeum fordii, Gironniera subaequalis, Hopea odorata, Peltophorum tonkinensis. This species is fast-growing and light demanding. Flowering: March to May; fruiting: June to October.

Uses - Wood used for sawing board, house construction, and fuel. The resin is used for incense or as perfume oil, turpentine, and raw material for paint and printing industries. Fruit edible and used against diarrhoea and rheumatism. Seeds contain edible oil. 
Specimens examined: Balansa 3706 (P); Brillet 5 (P); Cuong 391 (L); Fleury 30122, 37542, 37960 (L, P), 30141 , 37921 , 38026 (L); Pételot 5751 (P); Poilane 29914 (P); Thirlot s.n. (P); Tsang 39334 (L).

\section{Canarium pimela Leenh.}

Synonym - Canarium tramdenum C.D. Dai \& Yakovlev

Vernacular names - Bai (L); Trám đen (V).

Large trees up to $30 \mathrm{~m}$ high, $90 \mathrm{~cm}$ diameter. Trunk cylindrical. Bark light brown, fissured with many lenticels, inner bark pinkish brown, aromatic with black sap. Stipules absent. Petioles 7-9 cm long, swollen at base. Leaves imparipinnately compound, 30-65 $\mathrm{cm}$ long. Leaflets opposite, $2-4$ pairs, elliptic, $7-18$ by $3-6.6 \mathrm{~cm}$, stiff, crustaceous, smooth above, dark coloured beneath, apex distinctly acuminate or pointed, margin entire, oblique at base, petiolules 3-6 mm long. Inflorescences panicles, longer than the leaves. Flowers unisexual, dioecious, pedicel $6-8.5 \mathrm{~cm}$ long. Calyx cupular, lobes deltoid, outside hairy or glabrous, inside densely silky-hairy. Petals 3 , cream-white, free, usually overlapping in bud, outside hairy in centre, inside usually glabrous. Stamens 6 , in one whorl, united at base. Filaments flattened. Disc within stamens, 6-lobed, strongly developed in male flower. Ovary ovoid, 3-celled. Fruit a long-ovoid drupe, 3-4 by $1.5-2 \mathrm{~cm}, 3$ unequal loculi, dark violet when ripe; calyx persistent in fruit. Stone hard, woody, surface smooth, rounded at both ends, 3-celled. Seed one per cell.

Distribution - South East China, Indochina. In most provinces of Laos, mainly in Xieng Khouang, Houa Phan, and Vientiane. In almost all provinces in northern Vietnam, mainly in Bac Thai, Tuyên Quang, Kiên Giang, Vinh Phu, Hà Tây, Hoa Binh, Ninh Binh, Thanh Hoa, Nghê An, and Quang Binh.

Habitat \& Ecology - In primary and secondary forests, altitude below $500 \mathrm{~m}$. Usually mixed with Aglaia gigantea, Eberhardtia tonkinensis, Erythrophloeum fordii, Garcinia spp., Gironniera subaequalis, and Pygeum arboreum. This species is fast-growing and light demanding, preferring deep humid soil and moderately steep topography. Natural regeneration is good under a forest cover of $30-40 \%$. Flowering: April, May; fruiting: May to September.

Uses - The wood is used for sawing board, house building, and furniture. Fruits are edible. Fruits and leaves are used against diarrhoea and rheumatism. Seeds contain edible oil.

Specimens examined: Balansa 3694, 4602 (P); Bon 1545 (P); Cuong 103 (L); Fleury 30091, 30141, 37833 (P); Forestier 7, 8 (P); Kerr 20890 (P); Poilane 2013 (P).

\section{CAESALPINIACEAE}

Trees, shrubs, sometimes lianas, rarely herbs. Buttresses sometimes present. Stipules nearly always present, stipes usually lacking, minute when present. Leaves usually spirally arranged, rarely opposite or alternate, pinnate, bipinnate, or unifoliolate, rarely simple; sometimes with translucent dots; leaflets entire. Inflorescences axillary and/ or terminal, usually in racemes, panicles or spikes, rarely solitary flowers. Flowers regular or irregular, large to small, often showy, bisexual. Sepals adnate, normally 
5-lobed, overlapping or separate. Petals usually 5, sometimes imperfectly developed or absent, sometimes only one (Afzelia xylocarpa, Sindora), slightly unequal, the upper petal distinctive and innermost in bud; stamens free or joined, 10 or fewer, sometimes staminodes present; anthers dehiscing by lateral slits or terminal pores, ovary superior. Fruit a pod, sometimes indehiscent, sometimes winged, or fleshy and drupe-like.

Distribution - In tropical and subtropical regions of the world: c. 180 genera, 25003000 species. In Vietnam: 20 genera, 97 species. In Laos: 18 genera, 71 species.

\section{KEY TO THE GENERA}

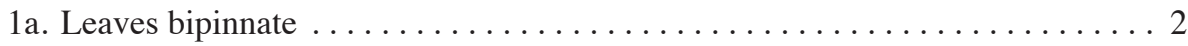

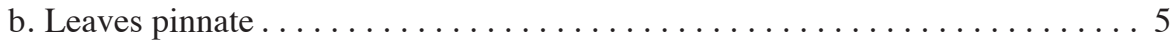

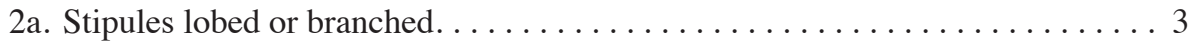

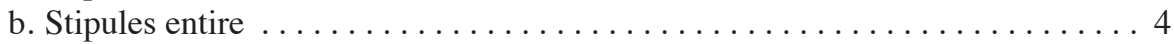

3a. Petals with long claw. Pods dehiscent, glabrous . . . . . . . . 5. Delonix

b. Petals not clawed. Pods indehiscent, glabrous or hairy . . . . . . 7. Peltophorum

4a. Plants armed with spines. Bracteoles absent. Fertile stamens 10. Pods dehiscent or

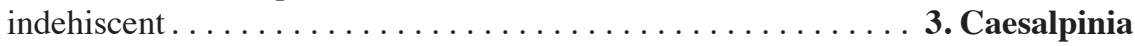

b. Plants not armed. Bracteoles present. Fertile stamens 5. Pods dehiscent . . . . . .

1. Acrocarpus

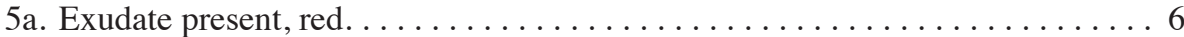

b. Exudate absent. . . . . . . . . . . . . . . . . . . . . . . . 7

6a. Leaves paripinnate. Sepals 4. Petal 1. Fertile stamens 7. Pods dehiscent 2. Afzelia

b. Leaves imparipinnate. Sepals 5 (rarely 3). Petals absent. Fertile stamens 2 (rarely

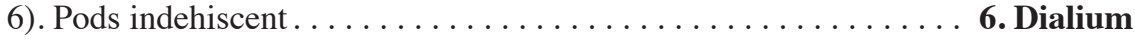

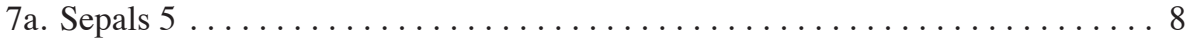

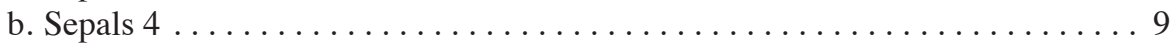

8a. Bracteoles present. Filaments straight or curved. Anthers dehiscing by apical

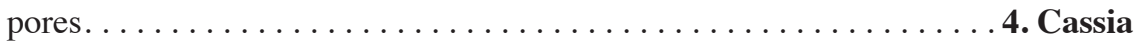

b. Bracteoles absent. Filaments straight. Anthers dehiscing by slits or basal pores .. $\ldots \ldots \ldots \ldots \ldots \ldots \ldots \ldots \ldots \ldots \ldots \ldots \ldots \ldots \ldots \ldots \ldots$. Senna

9a. Leaflets $2-5$ (rarely more) pairs, $30-150$ by $20-80 \mathrm{~mm}$. Sepals spiny outside. Petal 1. Fertile stamens 10. Pods dehiscent, flattened . . . . . . 9. Sindora

b. Leaflets $10-20$ pairs, $8-30$ by $3-10 \mathrm{~mm}$. Sepals not spiny outside. Petals 5 . Fertile stamens 3 . Pods indehiscent, thickened . . . . . . . . 10. Tamarindus

\section{ACROCARPUS Wight \& Arn.}

Acrocarpus fraxinifolius Wight \& Arn.

Synonym - Acrocarpus combretiflorus Teijsm. \& Binn.

Vernacular names - Ket hoy (Sayabouri), Khan khak (Louang Prabang) (L).

Trees up to $50 \mathrm{~m}$ high, deciduous at the beginning of the cold season, often with buttresses when older. Bark pale grey with large brown lenticels, inner bark pinkish. Heartwood dark red. Young shoots appressed yellowish tomentose. Stipules triangular, small, 1-2 mm long, usually early caducous. Leaves up to $100 \mathrm{~cm}$ long, bipinnate with 
3-5 pairs of pinnae. Leaflets 4-9 pairs per pinna, ovate, $4-14$ by $2-7 \mathrm{~cm}$, slightly oblique at the base, apex acuminate, subsessile; young leaves pink, pubescent beneath; mature leaves pale green, glabrous. Inflorescences racemes 1-3 together, dense, 20-25 $\mathrm{cm}$ long. Pedicels 6-8 mm long. Flowers reflexed after anthesis. Receptacle pubescent. Sepals 5,3-4 mm long, apex rounded, bright green, pubescent. Petals 5, red, obovate, $5-10$ by $1-2.5 \mathrm{~mm}$, apex acute, pubescent on both surface. Stamens 5 , yellowish orange, green at base, glabrous, twice as long as petals. Style short, curved, pale green, stigma small, ovules $15-20$. Pods long-stalked, $8-15$ by $1-2 \mathrm{~cm}$, flat, slightly torulose, with a $3-5 \mathrm{~mm}$ broad wing along the upper suture, dehiscent. Seeds $12-18,6.5$ by $5 \mathrm{~mm}$, lens-shaped, pale brown.

Distribution - India (Sikkim, Assam), Myanmar, Thailand, Indonesia (Sumatra, Java). In Laos: Louang Prabang (Phou Phung) and Sayabouri (Pak Lep) provinces. In Vietnam not yet recorded.

Habitat \& Ecology - In evergreen gallery-forests, altitude 400-1100 m. Flowering: January, February after shedding the leaves (pers. obs.).

Uses - Timber used for indoor constructions and for plywood.

Note - We have seen only one specimen from Laos at the Paris Herbarium. The description is mainly based on specimens from Thailand.

Specimens examined: Dussaud 84 (P); Poilane 20290 (L); Maxwell 90-369, 96-545, 97-143(L); Teijsman s.n. (L); Wight 845 (P).

\section{AFZELIA Sm.}

\section{Afzelia xylocarpa (Kurz) Craib - Fig. 10}

Synonyms - Afzelia cochinchinensis (Pierre) Leonard; A. siamica Craib; Pahudia cochinchinensis Pierre; P. xylocarpa Kurz

Vernacular names - Tae kha, Kha, Go ca te (L); Gỏ đỏ (V).

Deciduous trees up to $30 \mathrm{~m}$ high, up to $100 \mathrm{~cm}$ diam. or sometimes even more. Crown broad, rounded. Trunk stout, usually dividing near base into large, spreading branches. Bark smooth or slightly rough, grey or yellowish, inner bark reddish, forming burls when cut. Stipules minute, usually early caducous. Leaves $18-25 \mathrm{~cm}$ long, paripinnate with 3-5 pairs opposite leaflets. Leaflets elliptic, $5-9$ by $4-5 \mathrm{~cm}$, base rounded or truncate, apex obtuse to acute, slightly emarginated, young leaflets pubescent, mature leaves completely glabrous, sometimes pubescent below. Inflorescences panicles 5-15 $\mathrm{cm}$ long, greyish pubescent. Pedicels 7-10 mm long. Bracts ovate to narrowly elliptic, 6-9 mm long, greyish pubescent; bracteoles 2, as the bracts, persistent. Sepals 4, narrowly elliptic, 10-13 mm long, finely velvety outside. Petal 1, broadly elliptic, 7-9 $\mathrm{mm}$ long, pink or reddish, claw thin, 5-12 mm long, apex emarginate, hairy at the base. Fertile stamens 7 or 8 , filaments $30 \mathrm{~mm}$ long, pubescent at base; anthers $3-4 \mathrm{~mm}$ long, opening by a slit. Sterile stamens 3 , shorter than the fertile ones, filiform. Ovary hairy along both sutures, c. $7 \mathrm{~mm}$ long, stipe $7 \mathrm{~mm}$ long, style glabrous, 20-25 mm long, slightly enlarged towards the stigma. Pods brown, woody, $15-20$ by 7-9 $\mathrm{cm}$, dehiscent, valves $5-7 \mathrm{~mm}$ thick. Seeds $2.5-3$ by $2-2.5$ by $0.8-1.2 \mathrm{~cm}$, aril orange, cup-shaped, c. $1.5 \mathrm{~cm}$ long. 


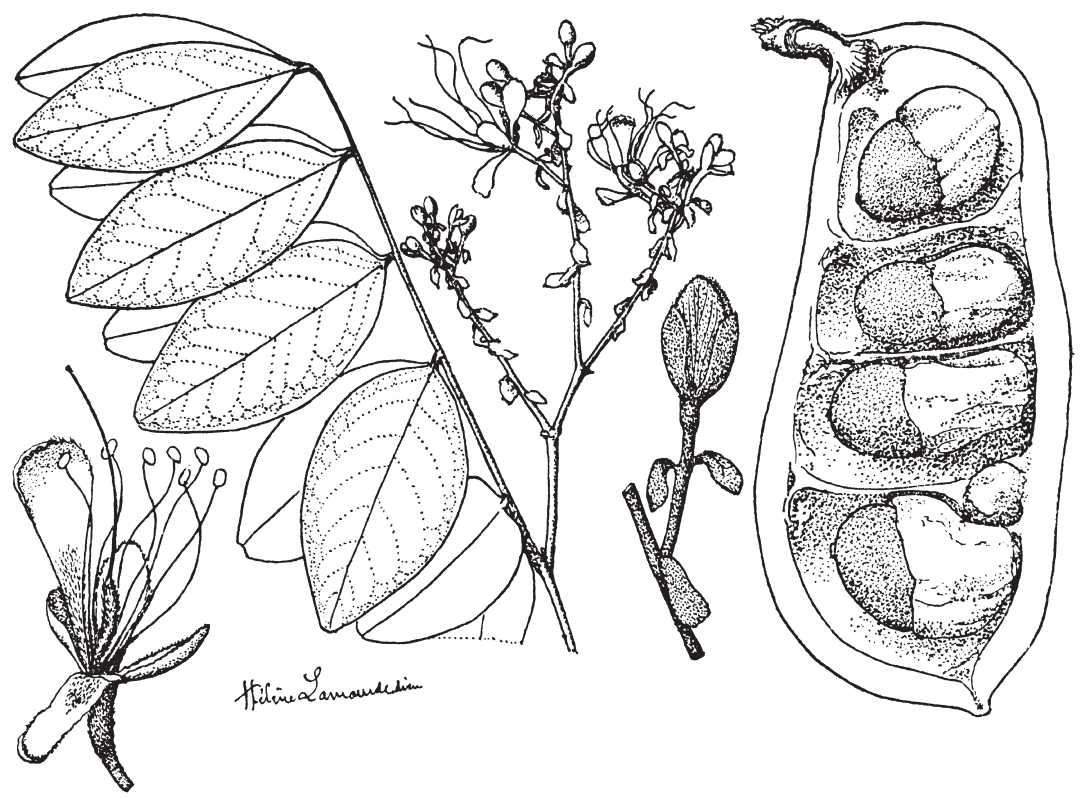

Fig. 10. Afzelia xylocarpa (Kurz) Craib (Caesalpiniaceae).

Distribution - Myanmar, Indochina, Thailand. In Laos: Vientiane (Ban Na Kham) and Savannakhet (Muong Tin) provinces. In Vietnam: Gia Lai, Bac Thai, Dông Nai, Ninh Thuân, Tây Ninh, and Hô Chi Minh provinces.

Habitat \& Ecology - In mixed deciduous and dry evergreen forests at lowland altitudes, in transitional zones between evergreen and dry open Dipterocarp forest. Flowering: March, April; mature fruits: October to December.

Uses - Timber used for construction, cabinet work, furniture, and in wood carving industries. Young seeds edible.

Specimens examined: Chevalier 29937, 32031 (L), 4, 30074, 31315, 32031 (P); Dong 168 (P); Hiep 458 (P); Muller 907 (P); Pierre 497 (P); Poilane 5540, 6803, 8477 (L, P), 10064 (L), 7912, 9794, 10046, 12500, 40791 (P); Tileury 29937 (P).

\section{CAESALPINIA L.}

\section{Caesalpinia sappan L. - Fig. 11}

Vernacular names - Fang deng, Fang pa (L); Vang, Vang nhuộm (V).

Small trees or shrubs up to $20 \mathrm{~m}$ high, 20-30 cm diameter. Bark pale grey studded with pale brown lenticels, young twigs and buds finely brown hairy. Spines small, strong, a pair at each leaf-base and several scattered. Stipules 3-4 mm long, usually caducous, often in 3 on the twigs, often a few on the underside of the petiole. Leaves bipinnate, $15-40 \mathrm{~cm}$ long; pinnae $8-16$ pairs. Leaflets $6-14$ pairs per pinna, opposite, subsessile, ovate, $10-20$ by $6-10 \mathrm{~mm}$, base asymmetrical, apex slightly emarginate. 


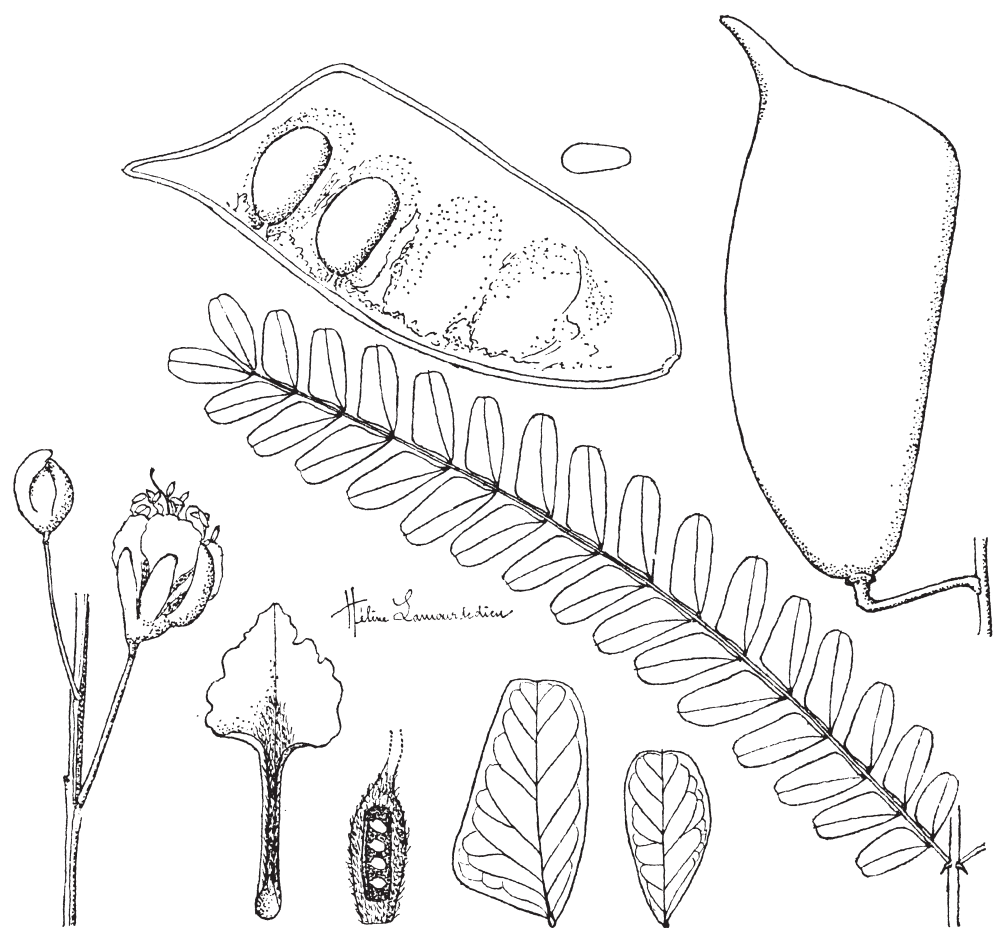

Fig. 11. Caesalpinia sappan L. (Caesalpiniaceae).

Inflorescences racemes, above the axil of leaves, or combined into terminal panicles. Bracts narrowly ovate, $6 \mathrm{~mm}$ long, acuminate, caducous. Pedicels $15-20 \mathrm{~mm}$ long, pubescent. Sepals 5, overlapping, glabrous, the lowest one more concave and larger. Petals 5, the 4 outer ones rounded, large, the fifth petal (standard) smaller. Stamens exserted; filaments c. $15 \mathrm{~mm}$ long, hairy at base; anthers c. $1.5 \mathrm{~mm}$ long, glabrous. Ovary greyish pubescent, with 3-6 ovules, style filiform. Pods pale green when young, reddish brown when mature, pubescent at both sutures, woody, irregular obovate-elliptic, flattened, $7-12$ by $1.5-2 \mathrm{~cm}$, sessile on the receptacle. Seeds $2-4$, elliptic in outline, $18-20$ by $10-12 \mathrm{~mm}$.

Distribution - India, Myanmar, South China, Indochina, Thailand. In Laos: Louang Prabang, Sayabouri (Pak Lay), and Savannakhet provinces. In Vietnam: Hà Nôi, Quang Ninh, Thanh Hoa, Dông Nai, Gia Lai, Hô Chi Minh, and Sông Bé provinces.

Habitat \& Ecology - In secondary forest, near roadsides, at the forest-edges, limestone hills, and cultivated around villages, buildings, or in parks. Flowering: June to December; fruiting: December to May.

Uses - Wood is used for wood-carving. Bark is used as yellow dye and wood as red dye. The wood is also used to cure haemostatic and diarrhoea.

Specimens examined: Balansa 1294, 1295, 2148 (P); Bon 2952, 4570, 5471 (P); Chevalier 32516 (L); Cuong 506 (L); Evrard 1744 (P); Fleury 37770 (P); Hiep 134 (P); Lefèvre 100 (P); Poilane 1772, 5184 (L, P), 130, 11515, 12040 (P); Thorel 102 (P); Vidal 2054 (P). 


\section{CASSIA L.}

\section{Cassia fistula L.}

Vernacular names - Khoun (General), Lom leng (Sayabouri Prov.) (L); Muồng hoàng yến, Bò cạp nước $(\mathrm{V})$.

Deciduous trees up to $20 \mathrm{~m}$ high, up to $50 \mathrm{~cm}$ diameter. Branches glabrous, spreading and drooping. Bark pale brown or dark grey, smooth or slightly cracked; inner bark reddish brown. Sapwood white, heartwood yellow. Stipules small, usually falling early. Petioles 6-10 cm long, rhachis $15-25 \mathrm{~cm}$ long. Leaves paripinnate, $30-40 \mathrm{~cm}$ long. Leaflets opposite, $3-8$ pairs, broadly ovate-elliptic, $7-18$ by $4-8 \mathrm{~cm}$, base cuneate to obtuse, apex acuminate to acute, with silky hairs when young, glabrous when mature, without glands, secondary veins numerous; petiolules 4-10 mm long. Inflorescences axillary, clustered racemes, $20-40 \mathrm{~cm}$ long, pendent, lax. Bracts $8-10 \mathrm{~mm}$ long, caducous. Pedicels 15-35 mm long, glabrous. Flowers bright yellow. Sepals 5, ovateelliptic, 5-10 mm long, velutinous outside. Petals 5, broadly ovate, 20-35 by $10-15$ $\mathrm{mm}$, subequal, claw short. Stamens 10, unequal, 3 long ones with filaments $3-4 \mathrm{~cm}$ long, anthers $5 \mathrm{~mm}$ long opening by apical and basal slits; 4 shorter with filaments $6-10 \mathrm{~mm}$ long, anthers opening by basal pore; reduced stamens 3 with filaments $3-5 \mathrm{~mm}$ long and minute anthers. Ovary and style velutinous, stigma small. Pods pendulous, terete, tube-like, 20-60 cm long, 1.5-2 cm diam., indehiscent, glabrous, black. Seeds numerous, separated by spongy septa, elliptic, flattened, $8-9$ by $4-6 \mathrm{~mm}$, glossy, brown.

Distribution - Egypt, India, China, Indochina, Thailand, Malesia. In Laos: Louang Prabang (Namkhan, Xieng Ngeun, Ban Na Luang), Houa Phan (Houa Phan), Sayabouri (Pak Lay), Vientiane (Vientiane-Thakhek), Savannakhet (Muong Phalane), Saravane, and Champassak provinces. In Vietnam: Kon Tum, Gia Lai, and Dac Lac, and cultivated in Hà Nôi, Nghê An, Hô Chi Minh, and Sông Bé.

Habitat \& Ecology - In (sub)tropical climate, with an average annual temperature of $25^{\circ} \mathrm{C}$, in mixed deciduous forests, in dry deciduous Dipterocarp forests. Annual rainfall should be over $1227 \mathrm{~mm}$. Tree, inclining towards light demanding, young trees slightly shade demanding and drought tolerant. Flowering: April to July; fruiting: May to August.

Uses - Timber used for construction, implements, and agricultural tool-making. Trunk bark is rich in tannin and used in dyeing. Pods and seeds used for medical purposes (laxative). Bark is traditionally used for treatment of wounds from snake bites and scorpion stings. Trees are planted for ornamental purposes.

Specimens examined: Chamni 9944 (L); Maxwell 97-60 (L); Pedrond 172 (P); Phengkhlai 37895 (L); Poilane 2185 (L, P), 11406, 13299, 13346, 13788, 17975, 20153, 20207, 20784, 27975 (P); Pottier 88, 514, 838 (P); Saydara 034 (L); Schmid s.n. (P); Thorel 2725 (P); Vidal 932 (P).

\section{DELONIX Raf.}

Delonix regia (Bojer ex Hook.) Raf.

Basionym - Poinciana regia Bojer ex Hook.

Vernacular names - Fang hang nhoung, In si (L); Phượng, Diệp bông đỏ, Diệp tây (V). 
Deciduous trees up to $15 \mathrm{~m}$ high. Crown umbrella-shaped. Trunk more or less buttressed. Bark grey, smooth. Stipules pinnately 4 or 5 lobed, c. $2 \mathrm{~mm}$ long, caducous. Leaves bipinnate, main rhachis 50-60 cm long; pinnae opposite, 9-24 pairs, up to $10 \mathrm{~cm}$ long. Leaflets 10-40 pairs per pinna, opposite, subsessile or sessile, narrowly elliptic, $5-15$ by $2-5 \mathrm{~mm}$, base slightly oblique, apex rounded, mucronate, both surfaces finely puberulous, glabrescent. Inflorescences axillary, racemes, 10-15 cm long, glabrous. Flowers 5-10. Pedicels 5-8 cm long. Hypanthium shortly bell-shaped. Sepals 5, narrowly elliptic, $4-7$ by $2-2.5 \mathrm{~mm}$, apex acuminate, reddish inside. Petals 5 , unequal, total length 3-7 cm long, blade orbicular, 3-4 cm wide, narrowed into an up to $3 \mathrm{~cm}$ long claw, one yellowish white and scarlet, the others only scarlet. Stamens 10, equal in length; filaments up to $4 \mathrm{~cm}$ long, red with white base; anthers elliptic c. $4 \mathrm{~mm}$ long. Ovary slightly velutinous; style filiform, glabrous, c. $2.5 \mathrm{~cm}$ long; stigma indistinct. Pods narrowly elliptic, flat, slightly curved, pendulous, $30-80$ by $3.5-7 \mathrm{~cm}$, woodyvalved, blackish, beaked. Seeds 20-40, elliptic, compressed, 25 by $8 \mathrm{~mm}$.

Distribution - Endemic to Madagascar. Widely cultivated in the tropics under the name 'Flamboyant' or 'Flame Tree'. In Laos and Vietnam planted in all tropical parts.

Habitat \& Ecology - Cultivated around villages, buildings, or in parks, along roadsides. Flowering: April to July; fruiting: May to August.

Uses - Planted for shade and ornamental purposes, seeds edible.

Specimens examined: Clemens 3300 (P); Dau 2341 (P); Dournes s.n. (P); Hiep 507, 872 (P); Jarois 79 (P); Phuc Nhac 1614 (P); Poilane 11729 (P), 11892 (L, P).

\section{DIALIUM L.}

Dialium cochinchinensis Pierre - Fig. 12

Vernacular names - Kheng (L); Xoay, Lá mét, Xài mét (V).

Large deciduous trees up to $35 \mathrm{~m}$ high, bole $16-18 \mathrm{~m}$ high, $80-100 \mathrm{~cm}$ diameter, rarely $150 \mathrm{~cm}$. Trunk straight, buttresses inconspicuous. Bark generally grey or whitish, slight ly rugose, inner bark 6-8 mm thick, hard, brownish, exuding a little transparent resin, soon turning red. Stipules small, caducous. Leaves imparipinnate. Petioles $12-20 \mathrm{~mm}$ long, glabrous or pubescent; rhachis $5-15 \mathrm{~cm}$ long, glabrous or glabrescent. Leaflets $5-9$, alternate, broadly ovate to elliptic, $4-7$ by $1.5-4.5 \mathrm{~cm}$, base rounded to acute, slightly oblique, apex obtuse to tapered acuminate, secondary veins $6-10$ pairs, anastomosing near the margin; petiolules 4-5 mm long, sparsely pubescent. Inflorescences axillary or terminal, panicles, $10-30 \mathrm{~cm}$ (or more) long, pubescent. Pedicels $2 \mathrm{~mm}$ long, pubescent. Buds ovoid, 3-4 mm long. Sepals 5, elliptic, connected at the base into a short tube, $4 \mathrm{~mm}$ long, grey pubescent outside, glabrous inside. Petals absent. Stamens 2, filaments very short, c. $1 \mathrm{~mm}$ long. Ovary silky, style glabrous, sessile with 2 ovules, stigma small. Fruit a pod, ovoid, slightly laterally compressed, 15-20 by 8-15 $\mathrm{mm}$, finely pubescent to velvety. Seed $(s) 1$ or 2, elliptic, 9 by 6 by $3 \mathrm{~mm}$, longitudinally striate, covered by whitish pulp.

Distribution - Myanmar, Thailand, Indochina, Malaysia. In Laos: Vientiane (Hatxiafong, Ban Khuay Daeng, Sikhot Tabong Distr., Ban Ang Nhai) and Savannakhet (Ban 


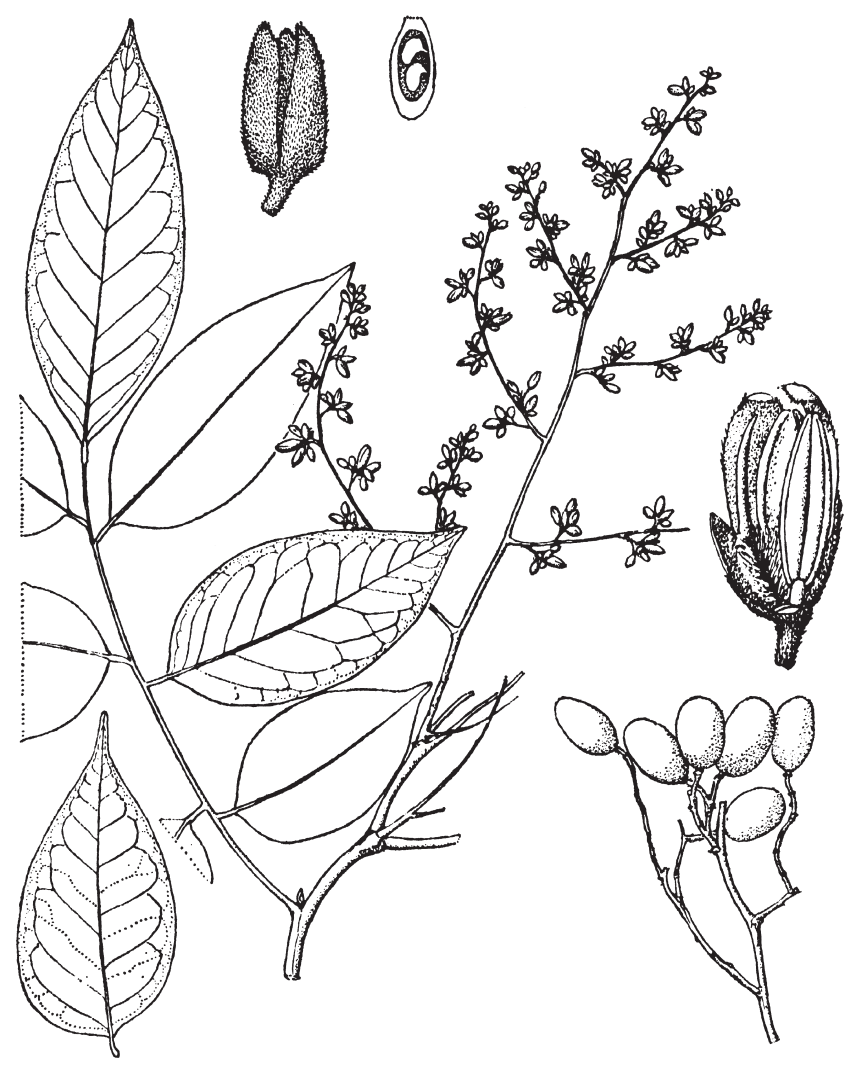

Fig. 12. Dialium cochinchinensis Pierre (Caesalpiniaceae).

That, Champhon, Ban Phay) provinces. In Vietnam: Nghê An, Hà Tinh, Kon Tum, Dông Nai, Sông Bé, Hô Chi Minh, and Ninh Thuân provinces.

Habitat \& Ecology - Primary or secondary forest, mountain slopes, on sandy brown soil, closed or open canopy forest, in dense evergreen or mixed deciduous forests, or transitional forest between evergreen and open Dipterocarp forest, altitude up to 800 $\mathrm{m}$, growing on well-drained basalt, along rivers, and stream banks. Growing together with species from the genera Altingia, Dalbergia, Dipterocarpus alatus, Pterocarpus, Stereospermum, Terminalia, and Shorea obtusa. Flowering: March to July; fruiting: June to November.

Uses - The wood is used for furniture, railway sleepers, heavy construction (staircases, doors and window frames), bridge, ship- and boat-building, vehicles, chopping board, and sport equipment, cart axles, agriculture implements, oil and sugar mills. Fruits are edible.

Specimens examined: Chevalier 39201 (P); Harmand 505 (P); Phung Van Dieu 38 (P); Pierre 814 (iso), 123, 244, 1026 (P), 1814 (L, P); Poilane 123, 141, 17866 (P), 6640 (L), 8460, 16365 (L, P); Soejarto et al. 10752, 11480 (L); Soejarto \& Sydara 10848, 10850 (L); Thorel 369, s.n. (P); Vinot $16(\mathrm{P})$. 


\section{PELTOPHORUM (Vogel) Benth.}

Peltophorum dasyrhachis (Miq.) Kurz - Fig. 13

Synonyms - Caesalpinia dasyrhachis Miq.; Peltophorum grande Prain

Vernacular names - Sa kham, Sa phang, Sa fang (L); Hoàng linh, Lim xet, Lim vàng (V).

Large deciduous trees up to $30 \mathrm{~m}$ high, 70-90 cm diam., open crown. Young shoots or branchlets reddish brown, pubescent, later glabrous. Bark greyish brown, lenticels present on twigs, inner bark dark brown to reddish brown. Stipules remarkably antlerlike, rather large. Leaves bipinnate, 15-32 cm long, pinnae 4-9 pairs, young leaves with dense reddish brown hairs. Leaflets 6-16 pairs per pinna, irregular elliptic,

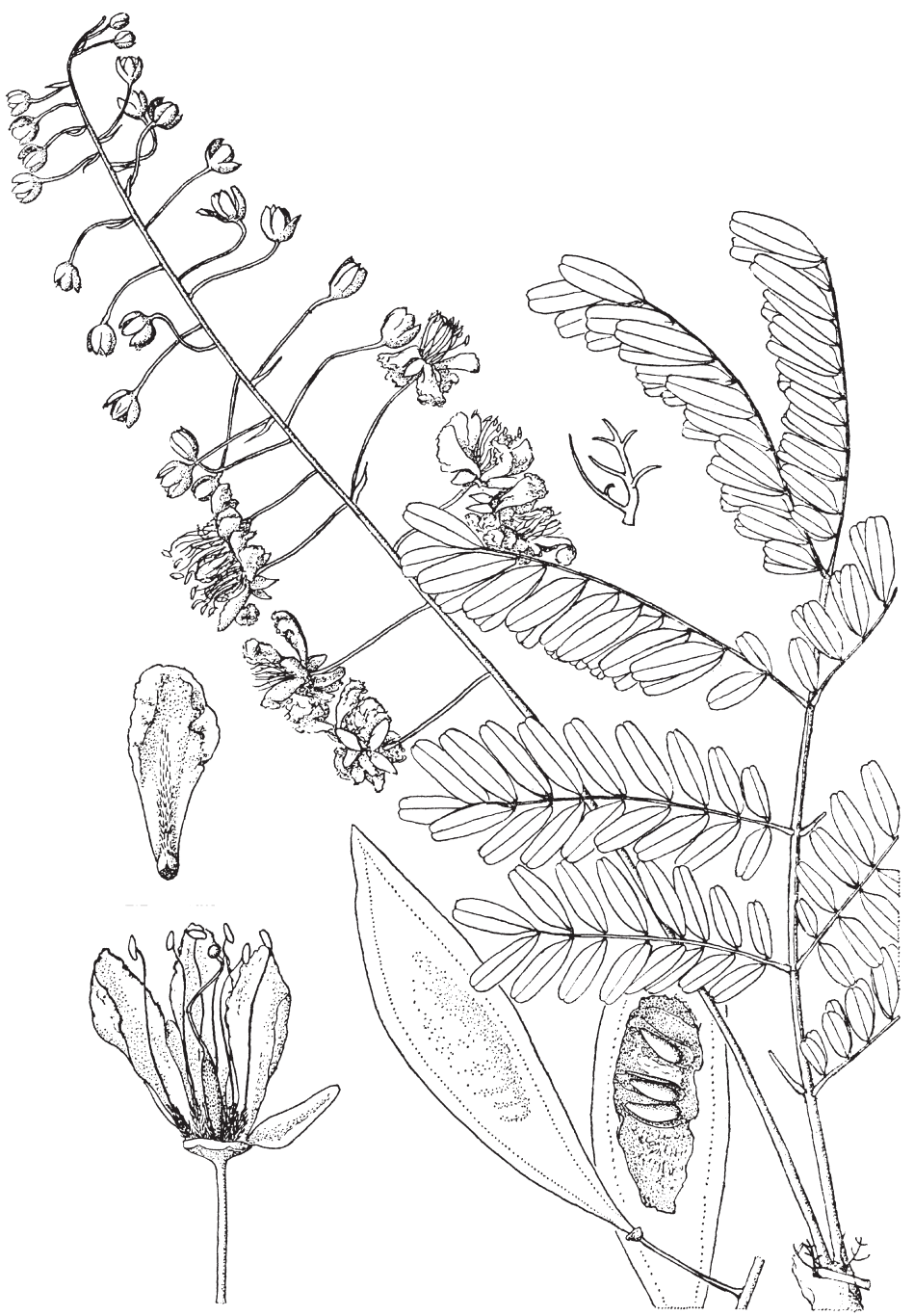

Fig. 13. Peltophorum dasyrhachis (Miq.) Kurz. (Caesalpiniaceae). 
$10-25$ by $4-10 \mathrm{~mm}$, base acute, obtuse or rounded, slightly oblique, apex rounded or slightly emarginated, above glossy dark green when mature, slightly brown hairy below. Inflorescence axillary, racemes, $15-30 \mathrm{~cm}$ long, with pubescent axis. Bracts persistent, linear, 7-12 cm long. Pedicels $20-40 \mathrm{~mm}$ long. Buds ovoid. Sepals broadelliptic, $10-15$ by $5-6 \mathrm{~mm}$, brownish or ruddy pubescent outside, glabrous inside. Petals yellow, obovate, $15-25$ by $10-12 \mathrm{~mm}$, hairy towards the base of the upper side. Stamens 10, fertile, with filaments \pm as long as petals, $10-15 \mathrm{~mm}$ long; anthers 4-5 mm long. Ovary sessile, velutinous, with $4-8$ ovules, style slender, stigma knob-like. Pods reddish brown, flattened, both ends tapered, $10-15$ by $2-3.5 \mathrm{~cm}$, margin thinly winged, 4-5 mm broad. Seeds 4-8, more or less transversally arranged in the pod, flat, $10-12$ by $5 \mathrm{~mm}$.

Distribution - Indochina, Thailand, Malaysia, Indonesia and furthermore widely cultivated. In Laos: Sayabouri (Pak Lay), Vientiane, Khammouane (Thakhek-Phong Tiou), and Saravane province (Pa Ta Lot). In Vietnam: Lang Son, Nghê An, Thua Thiên-Huê, Binh Dinh, Vinh Phu, Dac Lac, Khanh Hoa, Ninh Thuân, Dông Nai, Sông Bé, Tuyên Quang, Tây Ninh, and Kiên Giang provinces.

Habitat \& Ecology - In tropical deciduous and evergreen forest, bordering agriculture fields, altitude up to $800 \mathrm{~m}$. Light demanding when mature and shade tolerant when young. It is a pioneer species on shifting cultivation land or in secondary forests. Often mixed with Alangium kurzii, Engelhardtia chrysolepis, and Ormosia balansae. Flowering: February to April when the young leaves develop; fruiting: July to October.

Uses - Timber used for poles, house implements, vehicles, railway sleepers, and boat and ship building. Planted for ornamental purposes. Bark is used for medical purposes.

Note - K. Larsen, S.S. Larsen \& J.E. Vidal, Flore du Cambodge, du Laos et du Vietnam 18 (1980) 60-61 combined P. dasyrhachis and P. tonkinensis and gave them both only varietal rank. Gagnepain, Fl. Gen. Indochine (1916) and Dung, Vietnamese Forest Trees (1996) 425-426, however, considered them as two separate species i.e. $P$. dasyrhachis Kurz and P. tonkinensis (Pierre) Gagnep. They differ in the stipules: in P. dasyrhachis the stipules have many branches, remarkably antler-like; in P. tonkinensis the stipules have no or sometimes only two branches.

Specimens examined: Bon 5438 (P); Cuong, Kien \& Sinh 979 (L); Dussand 1 (P); Fleury 30142, 30201 (P); Hoi 165 (P); Honquan 799 (P); Lefèvre 312 (P); Maxwell 99-217(L); Muller 1805 (L,P); Parrean 171 (P); Phung Van Dieu 72 (P); Pierre 219 (P), 1813 (L, P); Poilane 6255, 17312 (L, P), 10678, 13733 (L), 6772, 13746, 30515 (P); Schmid 705, s.n. (P); Service Forester 14, 17, 27, 172 (P); Soejarto \& Southavong 10761 (L); Thorel s.n. (P); Vidal 1279, 5854 (P); Vinot 48 (P).

\section{SENNA Mill.}

Senna siamea (Lam.) Irwin \& Barneby

Synonym - Cassia siamea Lam.

Vernacular names - Khi lek (L); Muồng đen (V).

Evergreen or semi-evergreen, medium-sized trees up to $20 \mathrm{~m}$ high, $30-45 \mathrm{~cm}$ diameter. Bark nearly smooth. Lenticels present on twigs. Young branches striate, finely 
pubescent. Stipules minute, subulate, caducous. Petioles $2-3 \mathrm{~cm}$ long, rhachis $10-25$ $\mathrm{cm}$ long. Leaves paripinnate. Leaflets 7-10 (rarely 15) pairs, ovate to elliptic 3-7 by 1-2 cm, base rounded, apex slightly emarginate with a short mucronate tip, upper surface glabrous, lower surface finely pubescent; petiolules short. Inflorescences large, terminal panicles. Peduncle 5-7 cm long. Bracts obovate, $5 \mathrm{~mm}$ long, apex long acute. Bracteoles absent. Pedicels 2-3 cm long, velutinous. Sepals 5, orbicular, thick, unequal, 2 outer small, $5 \mathrm{~mm}$ long, 3 inner up to $9 \mathrm{~mm}$ long, outside pubescent. Petals 5, yellow, broadly obovate or ovate, 1-2 cm long, claws short. Stamens: 2 with filaments c. 10 $\mathrm{mm}$ long and anthers $6-7 \mathrm{~mm}$ long, opening by apical pores; 4 or 5 with filaments $2-3$ $\mathrm{mm}$ and anthers 5-6 $\mathrm{mm}$ long, opening the same way; 2 or 3 staminodes c. $3 \mathrm{~mm}$ long. Ovary densely velutinous, style glabrous, stigma indistinct. Pods flattened, glabrous or glabrescent, longitudinally waved with raised sutures, $15-30$ by $1-1.8 \mathrm{~cm}$. Seeds 20-30, ovate, broadly elliptic, flat, $10-25$ by $5-6 \mathrm{~mm}$, pale brown.

Distribution - South East Asia, India, Myanmar, China, Indochina, Thailand, Philippines. In Laos: Louang Namtha, Khammouane (Phong Tiou), and Champassak (Bassac, Sithandone, Khong) provinces. In Vietnam: Naturally distributed in Quang Binh, Kon Tum, Gia Lai, Khanh Hoa, Dac Lac, and Dông Nai provinces, and planted in many cities and provinces.

Habitat \& Ecology - Thrives in subtropical climates. Various types of forest at lower altitudes with an annual average temperature between $21-24{ }^{\circ} \mathrm{C}$. Neutral tree, inclining towards light demanding, adapted to calcareous, fertile alluvial soil, grows also on arid soil. Flowering: July to December; fruiting: January to April.

Uses - Timber used for indoor constructions and furniture. Flowers and young leaves edible. Can be planted as a shade tree along streets, or for cover in plantations, as ornamental in parks or roadside trees. The wood burns easily, producing much heat and is suitable for firewood. Locally used for medicinal purposes.

Specimens examined: D'Alleizette s.n.(L); Belval 61 (P); Chevalier 29544, 38659,39011, 39414 (L), 38342 (P), 40057 (L, P); Clemens 3624 (P); Dournes 284 (P); Fleury 38059, 39010, 39011 (P); Hiep 797, 900 (P); Krong-Pha 925 (P); Lamk 186 (P); Muong 40189 (P); Phung Van Dieu 6 (P); Pierre 5984 (P); Pételot 1112 (P); Poilane 19, 45, 4690, 8413 (L, P), 9819, 18552 (L), 18551, 26226, 40096 (P); Robinson 1446 (P); Thoauy 2302 (P); Thorel 2720 (P); Vidal 1087, 1278 (P).

\section{SINDORA Miq.}

Sindora siamensis Teijsm. - Fig. 14

Synonyms - Sindora cochinchinensis Baill.; S. wallichii var. siamensis (Teijsm. ex Miq.) Baker Vernacular names - Te nam (L); Gỏ mật, Gụ mật (V).

Deciduous or semi-evergreen trees up to $35 \mathrm{~m}$ high, 80-100 $\mathrm{cm}$ diam., cylindrical, much branched. Trunk 15-20 m high. Crown spreading umbrella-like. Bark dark brown with grey spots, slightly cracked and flaking when older, inner bark pinkish and rather fibrous. Twigs robust, compressed, lenticellate, yellow tomentose, glabrous. Stipules early falling, foliaceous, large, ovate, 13-18 mm long, base auricled, apex acute, reticulate veined and puberulous on both surfaces. Petioles $2-4 \mathrm{~cm}$ long; rhachis up to $10 \mathrm{~cm}$ long, both pubescent. Leaves paripinnate, $15-25 \mathrm{~cm}$ long. Leaflets 3 or 4 pairs, upper pair slightly larger than the others, broadly or very broadly elliptic, $6-15$ by $4-8$ 


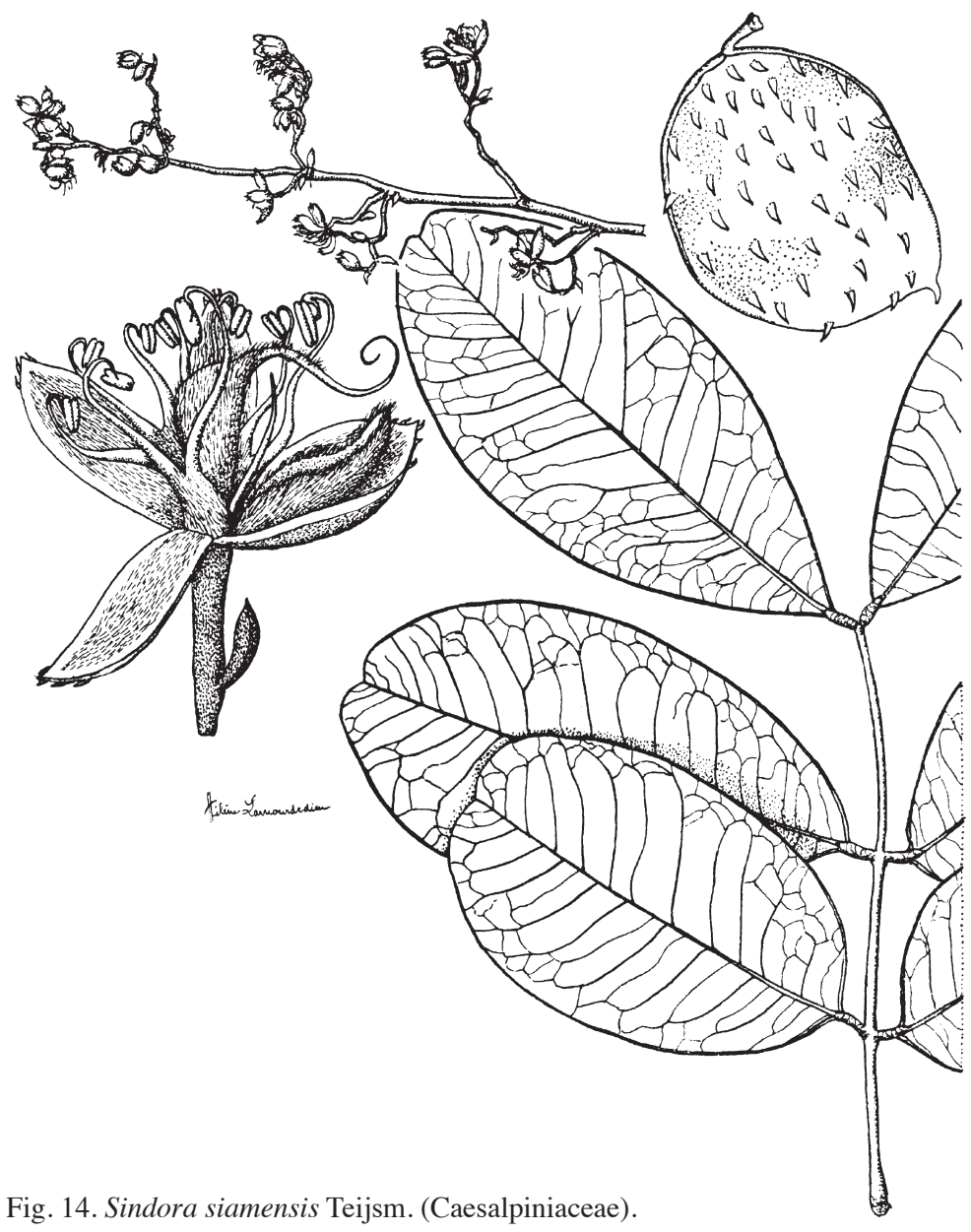

$\mathrm{cm}$, base broadly cuneate, acute, round to truncate, more or less unequal-sided, apex rounded or emarginated, both surfaces reticulate and slightly rough to the touch, upper surface minutely short-hairy, lower surface often more densely hairy especially on the midrib, lateral veins often straight to the margin. Inflorescences axillary or terminal, panicles, 10-35 cm long, with straight or zigzag axes, solitary, paired, or tripartite, densely brownish, pubescent. Bracts persistent during anthesis, foliaceous, large, ovate or heart-shaped, 3-7 mm long, outside densely puberulous, inside puberulous, pubescent on edge. Bracteoles long persistent, foliaceous, ovate, c. 5 by $2 \mathrm{~mm}$, puberulous on both surfaces. Pedicels 2-4 cm long, densely dark brown pubescent. Sepals 4, imbricate in bud, elliptic to broadly elliptic, 7-10 by $4-6 \mathrm{~mm}$, unequal-sized, outside puberulous, bearing several spinescent outgrowths near the apex and often showing numerous warts all over, inside glossy brown strigose. Petal 1, narrowly elliptic, 7-10 by 2-4 mm, when dry dull purple, claw involute, fleshy, with a central thick length zone; outside densely woolly hirsute, inside brown, glabrous. Stamens 10, the united basal parts of filaments very short; free filaments $15-20 \mathrm{~mm}$ long, slightly hairy at 
the lower part; fertile anthers various in size. Ovary subsessile, densely hirsute along the suture, spines appear later in development, ovules 3-8, style recurved, glabrous, 8-10 mm long, stigma terminal, knob-shaped. Pods armed with numerous stout spines, flattened, irregularly ovate or broadly elliptic, $4-10$ by $3-8 \mathrm{~cm}$, beak curved, $5-7 \mathrm{~mm}$ long. Seeds placed on top of a large aril, orbicular or broadly elliptic, flattened, 15-25 by 14 by $17 \mathrm{~mm}$; dry aril cushion-shaped, $10-15 \mathrm{~mm}$.

Distribution - China, Thailand, Indochina, Peninsular Malaysia. In Laos: Vientiane (Ban Keun, Nam Ngum, Sikhot Tabong Distr., Ban Ang Nhai, Phu Phanang), Savannakhet (Champhon Distr., Ban Phay), Saravane, and Champassak (Khong Island, Khong Distr.) provinces. In Vietnam: Kon Tum, Gia Lai, Dac Lac, Lâm Dông, Dông Nai, Sông Bé, Ninh Thuân, Khanh Hoa, and Tây Ninh provinces. This species has been planted in Hà Nôi Botanical Garden and Hô Chi Minh city zoo.

Habitat \& Ecology - Primary forest, remnants of forest with some bamboos, mixed evergreen forest, mixed deciduous forest, dry deciduous Dipterocarp forests.

Uses - Wood is used for construction posts, frame work, furniture, developing a beautiful appearance when used for a long time, the bark is used for dying fish nets. Can be planted as shade or ornamental trees due to its beautiful shape.

Specimens examined: Barry $57(\mathrm{P})$; Chevalier 39125 (P); Dournes s.n.(P); Hiep 458 (P); Lecomte s.n. (P); Maxwell 98-459 (L); Muller 1790 (P); Pierre 127, 338, 1489, 6549 (P); Poilane 148, 6086, 9463, 9823, 13783 (P), 5612 (L, P); Service Forestier 5 (P); Soejarto \& Southavong 10903, 11481 (L); Thorel 996 (P); Tixier s.n. (P); Vidal 5909, 5945 (P); Vinot 1 (P).

\section{TAMARINDUS L.}

\section{Tamarindus indica L.}

Synonyms - Tamarindus occidentalis Gaertn.; T. officinalis Hook.

Vernacular name - Kham (L); Me (V).

Trees up to $25 \mathrm{~m}$ high, $100 \mathrm{~cm}$ diam., with dense rounded crown composed of many branches and twigs. Trunks of old trees often twisted and grooved, often fluted but not buttressed. Bark greyish brown, somewhat fissured and scaly, inner bark green-white. Stipules minute, caducous. Petioles and rhachis 5-16 cm long, slightly pubescent to glabrous. Leaves paripinnate. Leaflets sessile or subsessile, 10-20 pairs, elliptic, 8-30 by $3-10 \mathrm{~mm}$, base rounded, unequal, apex rounded or slightly mucronate, both surfaces glabrous. Inflorescences terminal or axillary racemes, 5-10 cm long, rarely up to 22 $\mathrm{cm}$, axis puberulous. Bracts and bracteoles ovate-elliptic, 5 by $3 \mathrm{~mm}$, caducous, lower surface pubescent, upper glabrous. Pedicels up to $14 \mathrm{~mm}$ long, puberulous, glabrescent. Sepals 4 , zygomorphic, imbricate, narrowly elliptic, $8-12$ by $4-5 \mathrm{~mm}$, inside yellow, slightly puberulous at the base, outside reddish, glabrous. Petals $3^{1}$, unequal, ovate-elliptic, $10-13$ by $2-6 \mathrm{~mm}$, yellowish orange or cream with red veins. Stamens less than 10 , up to $15 \mathrm{~mm}$ long, filaments connate for about half their length into a pubescent tube; fertile anthers 3 , longitudinally dehiscent; staminodes 4 or 5, tooth-like, alternating with fertile ones. Ovary stipitate, linear, c. $7 \mathrm{~mm}$ long, pubescent, ovules 8-14; style elongate, $7 \mathrm{~mm}$ long, pubescent; stigma terminal, subcapitate. Pods indehiscent, narrowly elliptic, $5-15$ by $1-3 \mathrm{~cm}$; slightly curved or straight, mesocarp pulpy, acid,

1) Often 2 lower, smaller petals are mentioned; however, they may be absent or overlooked. 
pale brown. Seeds up to 10, obovate-orbicular, 11-17 by 10-12 mm, compressed, glossy, dark brown.

Distribution - Originated from tropical Africa. Widely cultivated all over the tropics, e.g. India, Thailand, Indochina, Indonesia. In Laos: Planted in all tropical parts of the country. In Vietnam: Hà Giang, Tuyên Quang, Kiên Giang, Quang Ninh, Bac Thai, Lai Châu, Son La, Hoa Binh, Hà Tây, Ninh Binh, Thanh Hoa, Ninh Thuân provinces and some provinces of South Vietnam.

Habitat \& Ecology - Planted around buildings, gardens, coastal areas, and along roadsides in tropical regions, altitude below $500 \mathrm{~m}$. Flowering: March to July; fruiting: April to August, in Vietnam: May to December.

Uses - Wood used for firewood, for making furniture or agricultural tools, chopping blocks, charcoal for smelting gold. The acid pulpy part of the pods is used for various preserves, jams, sweets, and beverages, soup cooking. Seeds are edible and also used as vermicide. For traditional medicine the bark is used against diarrhoea. Bathing with an infusion of the boiled leaves helps against skin diseases, such as scabies. It can be used as a shade tree along streets.

Specimens examined: Balansa 2141 (P); Baudouin $27(\mathrm{P})$; Belval $84(\mathrm{P})$; Bon 1802, $1838(\mathrm{P})$; Brousmich s.n.(P); Chevalier 38045 (P); Clemens 3809 (P); Dupuy $146(\mathrm{P}) ;$ Dussaud 121 (P); Evrard 2530 (P); Hiep 155 (P); Hiroshine 30704 (L); Lecomte 1393 (P); Maxwell 89-617 (L); Pierre s.n. (P); Pindo 9 (P); Poilane 7956, 11473, 26729 (L, P), 11062, 27439 (P); Spire 928 (P); Squires 805 (P); Thorel s.n. (P); Tri $29(\mathrm{P})$; Waas $708(\mathrm{~L})$.

\section{CLUSIACEAE}

Trees, rarely shrubs, dioecious or monoecious. Crown monopodial, at least when young. Inner bark with a usually sticky yellow, sometimes clear or white exudate, occasionally very slowly appearing. Twigs usually quadrangular at first. Stipules absent, but sometimes with tiny reduced needle-like leaves resembling stipules. Petioles short. Leaves simple, opposite, and decussate, commonly leathery, with oil glands, sometimes visible as translucent dots or stripes, secondary veins usually numerous. Inflorescences panicles, racemes, cymes, or flowers solitary, terminal, axillary or on the twigs below the leaves. Flower actinomorphic, bisexual or unisexual, often with bracteoles below the calyx. Sepals $2-5$, free or basally connate. Petals $2-6$, free, imbricate or contorted; stamens usually numerous, free or united in fascicles; ovary superior, 1-5(-12)-locular, ovule(s) 1 or 2 per locule, style 1, stigma often large, flat. Fruit a drupe, berry or capsule, calyx persistent. Seeds without endosperm.

Distribution - Throughout all regions of the world, mainly in the tropics: c. 40 genera, c. 1000 species. In Vietnam: c. 6 genera, c. 60 species. In Laos: the number of genera and species is unknown.

\section{MESUA L.}

\section{Mesua ferrea L.}

Synonyms - Calophyllum nagassarium Burm.f.; Mesua nagana Gardner; M. nagassarium (Burm.f.) Kosterm.

Vernacular names - Ka thang, May lek (L); Vảp (V). 
Trees up to $30 \mathrm{~m}$ high, up to $95 \mathrm{~cm}$ diameter. Trunk straight, cylindrical, often fluted at the base. Bark dull brown, adherent scaly, irregular fissured; inner bark brownish red to pink or red, slowly exuding a yellow sticky sap. Young twigs slender, grey. Leaves elliptic, $4-15$ by $1-3.5 \mathrm{~cm}$, acute at both ends, margin entire, lower surface glaucous white, shiny, glossy green above. Young leaves pink. Petiole 4-10 mm long. Flowers solitary or paired, axillary, white, up to $9 \mathrm{~cm}$ diam., very aromatic, sepals 4 , petals 4 , stamens numerous, filaments yellow, ovary ovoid, superior, 2-locular, ovules 2 per locule, style long, stigma peltate. Fruit dark orange or purple brown, ovoid with pointed tip, 2.5-3.5 cm diam., calyx persistent. Seed(s) 1-4, woody, shiny brown.

Distribution - India, Sri Lanka, Myanmar, Thailand, Indochina, Peninsular Malaysia, Singapore. In Laos: Louang Prabang and Champassak provinces. In Vietnam: Kiên Giang, Vinh Phu, Hoa Binh, Thanh Hoa, and many provinces of the South, such as Gia Lai, Kon Tum, Quang Nam, Da Nang, Dông Nai, Hô Chi Minh, and Tây Ninh.

Habitat \& Ecology - Found in dense evergreen forest, altitude below 800 m, growing well in sandy soil or sand, or deep and thick clay soil. Shade tolerant when young, light demanding when mature. Successfully planted in Dông Nai province, Vietnam. Flowering: March to June; fruiting: May to August.

Uses - Timber dark red, very hard and heavy, grain fine, glossy, resistant to termites and insects, it is considered the hardest wood in Vietnam and Laos (internationally called iron wood). Used for making bridge poles, railway sleepers, and in house construction. Because of its beautiful shape and fragrant flowers, this species is usually planted around pagodas and temples in Vietnam.

Specimens examined: D'Alleizette 326 (P); Brillet 7 (P); Cadays 38252 (P); Chevalier 31298, 31312, 39128 (P); Evrard 2655 (P); Fleury 32118 (P); Forestier 30075 (P); Hiep 648, 1071 (P); Hô s.n. (P); Hooker s.n. (P); Martin 491 (P); Pételot 4817, s.n. (P); Pierre 1 (P), $1486(\mathrm{~L}, \mathrm{P})$; Poilane 6653, 26476 (P); Thorel 3397 (P); Vidal $4520(\mathrm{P})$.

\section{COMBRETACEAE}

Trees, rarely shrubs or woody climbers. Leaves simple, opposite, subopposite, spirally arranged or rarely alternate, margin entire or wavy (Lumnitzera), glabrous or hairy, often conspicuously scaly and often with domatia, stipules absent. Inflorescences terminal or axillary, spikes, racemes, panicles or globose heads. Flowers usually bisexual, or unisexual and some male flowers in the same inflorescences, actinomorphic or rarely zygomorphic, 4- or 5-merous, receptacle (calyx tube) usually in two distinct parts, the lower surrounding and adnate to the ovary and an upper part varying from short to long tube terminating in the calyx-lobes. Calyx-lobes 4 or 5, rarely more or almost absent. Petals 4 or 5 or absent (Anogeissus, Calycopteris, Terminalia), white, yellow, orange, red, or purple, glabrous or hairy, occasionally scaly. Stamens usually twice as many as petals, inserted inside the upper receptacle, often in two series, anthers attached at the back. Disc intra-staminal usually present, sometimes absent or very small. Ovary completely inferior, unilocular with usually 2 (occasionally up to 6) pendulous ovules, style simple, usually free. Fruit a 2-5-winged, ridged or angled, sessile or stipitate, usually indehiscent drupe. Seed 1 , pericarp usually thin and papery, sometimes leathery, rarely fleshy.

Distribution - Throughout tropics and subtropics: 18 genera, 450 species. In Laos: c. 5 genera, c. 20 species. In Vietnam: c. 6 genera, c. 25 species. 


\section{KEY TO THE GENERA}

1a. Leaves opposite or subopposite, without glands at petiole. Inflorescences axillary and terminal, globose heads. Fruits densely packed into a spherical head, a cap-

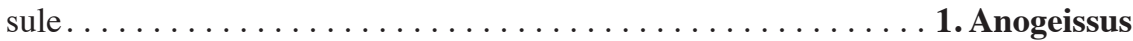

b. Leaves opposite, subopposite, or spirally arranged, often with a pair of cup-shaped glands at the top of the petiole. Inflorescences an axillary and terminal panicle. Fruits dry and winged or a drupe, usually densely arranged along the peduncle . .

2. Terminalia

\section{ANOGEISSUS}

Anogeissus acuminata (Roxb. ex DC.) Guill. ex Perr. - Fig. 15

Synonyms - Anogeissus harmandii Pierre; Conocarpus acuminata Roxb. ex DC.; C. hirtus Buch.Ham. ex Wall.

Vernacular names - Ben mon (L); Chò nhai, Râm (V), Xa rười, Sên (South Vietnam).

Large deciduous trees up to $40 \mathrm{~m}$ high, $100 \mathrm{~cm}$ diam., crown narrow, trunk long, straight, buttresses absent. Twigs slender, pendulous. Bark dark grey, slightly longitudinally fissured; inner bark whitish yellow. Stipules absent. Petiole 2-6 $\mathrm{mm}$ long, slender. Leaves subopposite, elliptic, $3-8$ by $1.5-4 \mathrm{~cm}$, acuminate or obtuse at base. Young leaves silvery with long silky hairs, venation pinnate, veins 5-9 pairs. Inflorescences axillary and/or terminal, globose heads, 1.3-1.8 cm diameter. Bracteoles caducous. Flowers yellowish green, bisexual, actinomorph, 4-5 mm diameter. Peduncle 7-13 mm long. Sepals united into a cup with 5 small lobes, hairy. Petals absent. Stamens 10 in two whorls, much longer than calyx cup. Disc velutinous. Ovary 2-celled. Fruits densely packed into a spherical head, $1.4-1.7 \mathrm{~cm}$ diam., each fruit $4-6$ by $3-5 \mathrm{~mm}$, with 2 wings and persistent calyx tube at the top.

Distribution - India, China, Indochina, Thailand. In Laos: Vientiane, Louang Prabang, and Savannakhet provinces. In Vietnam: in almost all provinces, mainly in Hoa Binh, Ninh Binh, Thanh Hoa, Nghê An, Quang Tri, Dông Nai, Lâm Dông, and Ninh Thuân.

Habitat \& Ecology - Found in tropical lowland open forest or semi-deciduous forests, altitude below $700 \mathrm{~m}$. This species is growing well in deep, humus-rich, loamy soils, along streams or river banks. Usually mixed with Pometia pinnata and Terminalia myriocarpa in the north or with Lagerstroemia calyculata, Pterocarpus pendatus, and Xylia xylocarpa in the south. Natural regeneration is good in open places in the forest. Flowering: May to July; fruiting: July to October or until March.

Uses - Sapwood and heartwood distinctive, sapwood yellow and heartwood greyish red. Poorly resistant to water or humidity, used for light construction, furniture, and musical instruments. This species can also be planted as an ornamental tree along roads, river banks or in parks.

Note - Two specimens (Soejarto et al. 10541, 11500, L) are aberrant as the tube of the calyx is nearly glabrous, as described for Anogeissus tonkinensis Gagnep. The tubes of the other specimens are densely hairy. Whether these forms are constant and need formal recognition as a variety cannot yet be determined. 


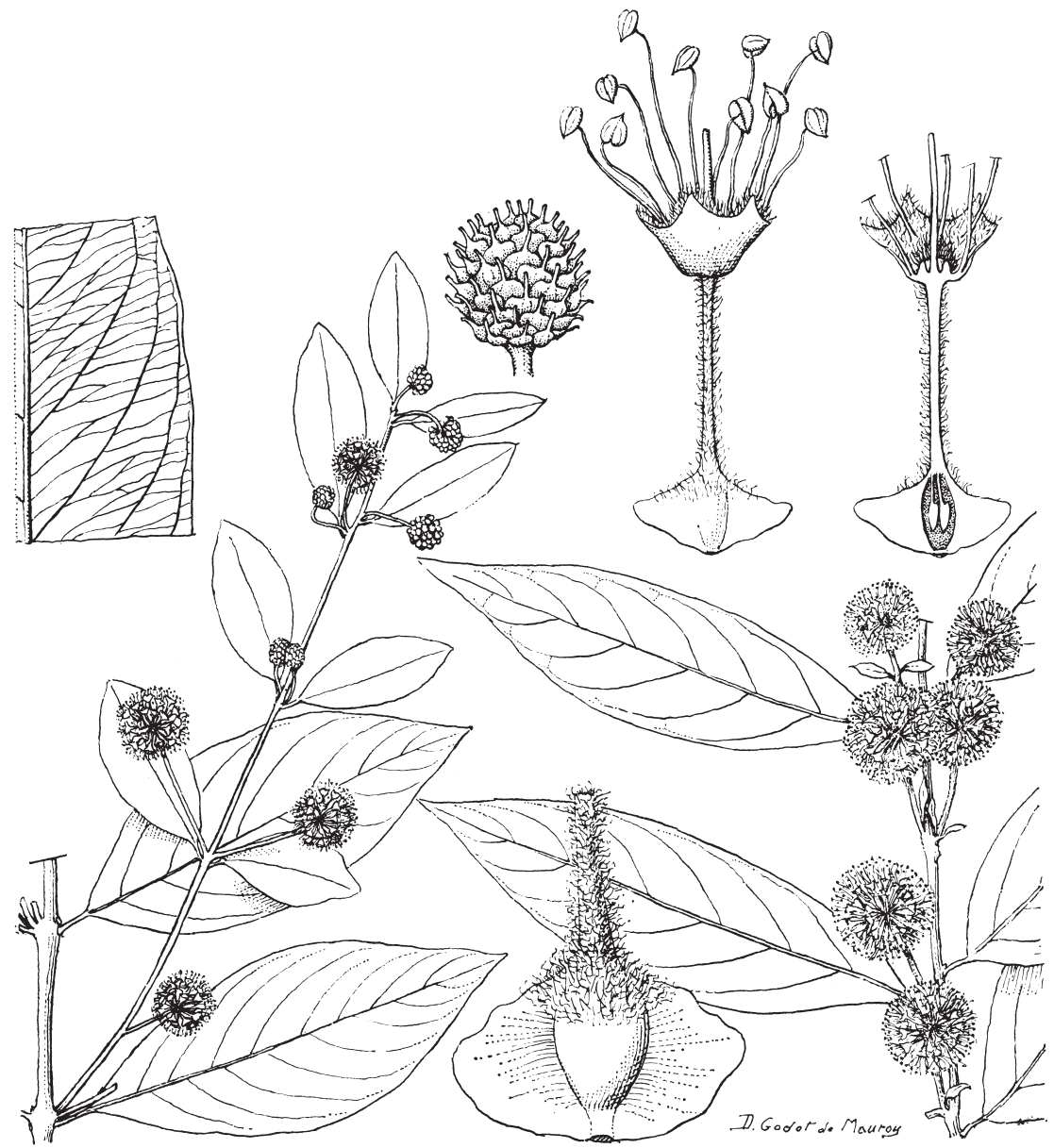

Fig. 15. Anogeissus acuminata (Roxb. ex DC.) Guill. ex Perr. (Combretaceae).

Specimens examined: Balansa 2394 (P); Chevalier 35684 (P); Dubrourdieu 39166 (P); Fleury 30914 (P); Forestier 35677 (P); Harmand 2905 (P); Hiep 127 (P); Magnen 37 (P); Poilane 6, 9796 (L), 1323, 5839, 21681 (L, P), 1786, 2536, 10059, 21636 (P); Soejarto et al. 10541, 11500 (L).

\section{TERMINALIA}

Terminalia myriocarpa Van Heurck \& Müll.Arg.

Synonyms - Myrobalanus myriocarpa Kuntze; Pentaptera saja Buch.-Ham.; Terminalia saja Steud.

Vernacular names - Kheo nua, Sam ta (L); Chò xanh (V).

Large, semi-deciduous trees up to $40 \mathrm{~m}$ high, up to $2 \mathrm{~m}$ diam., buttresses large, up to 4-5 m high. Twigs stout, horizontally spreading. Young branchlets tomentellous, sometimes rapidly glabrescent. Bark shallowly regularly cracked and flaky, inner 
bark yellowish brown. Stipules absent. Petiole often glabrous, thick, 3-9 mm long, with a pair of cup-shaped glands at the top. Leaves opposite or subopposite, elliptic, $14-20$ by $4-8 \mathrm{~cm}$, rounded or subcordate at base, margin entire or serrate, acuminate or pointed at apex, venation pinnate, veins $15-30$ pairs. Inflorescences axillary and terminal panicles, up to $35 \mathrm{~cm}$ long, peduncle $2-5 \mathrm{~cm}$ long, slender. Flowers bisexual, pinkish. Bracts hairy. Calyx lobes pubescent, triangular. Petals absent. Stamens 7-18, usually 10 , free, filament slender, glabrous. Disc usually hairy. Ovary 2-celled, style cylindrical. Fruits numerous, arranged densely along the peduncle, 2 -winged, $2-3$ by $10-13 \mathrm{~mm}$. Seed 1.

Distribution - Myanmar, China, Indochina, Thailand, Malaysia. In Laos: Louang Prabang and Vientiane provinces. In Vietnam: Lai Châu, Son La, Ninh Binh, Thanh Hoa, Nghê An, and Hà Tinh provinces.

Habitat \& Ecology - Evergreen primary and seasonal deciduous forests, altitude below $700 \mathrm{~m}$. Usually mixed with Castanopsis indica, Chukrasia tabularis, Dracontomelum dao, Parashorea chinensis, Pometia pinnata, and Toona sureni. This species grows on well-drained clay or sandstone soil, along rivers or in valleys. Flowering: August to October; fruiting: November to February of the next year.

Uses - Sapwood yellowish brown, distinguishable from the brown heartwood. Grain straight, easy to nail, glue, and peel off. Used for making nice veneer and plywood in construction, musical instruments, gymnastic equipments, and for ship planking.

Specimens examined: Balansa 3663 (L, P), 4445 (P); Bullock 813 (L); Domat 38128 (L, P); Dussaud 61 (L, P); Kerr 21229 (P); Poilane 20015 (L, P); Simons 51 (L); Thomson 50, 53 (L); Tiep s.n. $(\mathrm{P})$.

\section{DATISCACEAE}

Deciduous trees, usually with large buttresses, shrubs or herbs. Stipules absent. Leaves spirally arranged, simple or lobed, veins prominent, palmate. Inflorescences spikes or panicles. Flowers unisexual; regular, parts not overlapping. Bracts present. Male flowers: sepals connate in a tube, lobes 4-9; petals present or absent, free; stamens 4 or more, inserted on the sepals, filaments often long; sometimes with a pistillode. Female flowers: sepals tubular, lobes 4-8; petals absent or present; staminodes absent. Ovary inferior, 1-celled, carpels 3, ovules many on the wall, styles 3-8, simple or bifid, stigma variable. Fruit a leathery capsule, opening at apex with slits, or splitting laterally. Seeds numerous, very small.

Distribution - Asia and West Central America: 3 genera, 4 species. In Laos: only Tetrameles nudiflora.

\section{TETRAMELES R.Br.}

\section{Tetrameles nudiflora R.Br.}

Synonym - Tetrameles grahamiana Wight

Vernacular names - Phoung, Sa phoung (L); Thung (V).

Very large, deciduous trees up to $50 \mathrm{~m}$ high, $100-130 \mathrm{~cm}$ diameter. Trunk straight, very tall, buttresses large, up to $7 \mathrm{~m}$ high. Bark thin, pale silver-grey, smooth and shiny 
with large circular warts when younger, pock-marked when old, inner bark thick and soft, pale yellow-brown, fibrous. Twigs stout and spreading with large, prominent leaf scars. Stipules absent. Completely leafless from December to March. Petioles slender, 6-10 cm long. Leaves alternate, clustered near the end of twigs, broadly ovate or almost circular, $12-20$ by $10-15 \mathrm{~cm}$, base rounded or heart-shaped, margin irregularly and bluntly toothed and entire near the base, apex shortly acuminate, often slightly lobed, secondary veins 5, prominent, palmate. Young leaves silky hairy, mature leaves pale green, thin, minutely hairy below, distinctly raised above. Male and female flowers on different trees. Male panicles 8-18 cm long, much branched. Female spikes 10-27 $\mathrm{cm}$ long, mostly unbranched or with few branches. Male flowers: sepals 4, 1.5-2 mm long; petals absent, if present 1-4; stamens 4, about $3 \mathrm{~mm}$ long, opposite the sepals, surrounding a depressed disc. Female flowers: calyx bell-shaped, 4-toothed at the apex, sometimes with 1 or 2 smaller teeth, 3-5 mm long, petals absent, styles 4, opposite calyx teeth, $2 \mathrm{~mm}$ long. Fruits a capsule, 0.5 by $0.4 \mathrm{~cm}$, pale brown, ovoid or globose, finely ridged, outer layer very thin and papery with 4 openings and remains of calyx at he top. Seeds many, elliptic, very small.

Distribution - India, Sri Lanka, Myanmar, South China, Thailand, Indochina, Malesia, North Australia. In Laos: Sayabouri province and Vientiane Municipality (Sa Phan Meuk). In Vietnam: Cao Bang, Ninh Binh, Hoa Binh, Thanh Hoa, Nghê An provinces, and Botanical Garden in Hô Chi Minh city.

Habitat \& Ecology - Primary, secondary, deciduous forest, altitude up to $800 \mathrm{~m}$, along rivers or streams, on flat alluvial areas. The trees prefer deep, humus-rich, grey soil, sometimes growing on rocks. Flowering: January to April; fruiting: May to July.

Uses - For timber, furniture, plywood, ceiling boards, cheap planking, packing boxes, tea-chests, and matchboxes, and planted for ornamental purposes in parks.

Specimens examined: Chevalier 36730 (P); Hiep 433, 903 (P); Thorel 3256 (P); Vidal 1190 (P).

\section{DILLENIACEAE}

Evergreen or deciduous trees, without latex. Stipules absent. Petioles sometimes winged. Leaves simple, alternate or spirally arranged, usually clustered near the ends of twigs, secondary veins straight, parallel towards the margin, margin toothed. Inflorescences terminal or axillary, cymes or racemes, sometimes reduced to a single flower. Flowers bisexual, large, regular, yellow or white. Sepals free, overlapping, fleshy, becoming larger and completely covering the fruits. Petals free, overlapping in bud, opening early in the morning but quickly fallen off. Stamens many in two whorls; carpels clustered on a central cone. Fruits fleshy, covered by persistent, overlapping sepals, later splitting open.

Distribution - In the Old and New World: 10 genera, c. 350 species. In Laos: only Dillenia with 5 species. In Vietnam: 2 genera, 6 species.

\section{DILLENIA L.}

Dillenia ovata Wall. ex Hook.f. \& Thomson

Vernacular names - May san, San nhai (L); Sồ (V). 
Deciduous trees up to $30 \mathrm{~m}$ high, up to $100 \mathrm{~cm}$ diam., with rather knotted trunk and low-attached crown. Bark reddish or brown, flaky, inner bark reddish brown. Twigs slender, softly hairy. Petioles $2-4.5 \mathrm{~cm}$ long. Leaves ovate or elliptic, $10-20$ by 7-13 $\mathrm{cm}$, base rounded to acute, often unequal, margin finely toothed, apex rounded to obtuse, secondary veins 16-25 pairs, venation scalariform, densely velvety hairy beneath. Flowers solitary, terminal, very large, up to $16 \mathrm{~cm}$ diam., petals bright yellow with slight odour. Pedicel $0.5-1.7 \mathrm{~cm}$ long. Sepals ovate, $25-30$ by $15-25 \mathrm{~mm}$. Petals ovate, 7 by $5.5 \mathrm{~cm}$. Stamens in 2 distinct groups: outer ones curved, 16-20 mm long; inner ones reflexed at apex, $25 \mathrm{~mm}$ long. Carpels $10-12,6-7$ by $2-2.5 \mathrm{~mm}$, style 20 mm long, ovules many. Fruits indehiscent, pale yellow, globular, 4-6 cm diameter. Seeds blackish brown.

Distribution - Indochina, Thailand, Peninsular Malaysia, Indonesia (Sumatra, Bangka). In Laos: Savannakhet province. In Vietnam: Khanh Hoa, Quang Tri, Ninh Thuân, Dông Nai, Dac Lac, Quang Nam, Tây Ninh, and Bà Ria-Vung Tàu provinces.

Habitat \& Ecology — In open areas, mixed evergreen, deciduous, or dry Dipterocarp forest, or savannah, altitude up to $1500 \mathrm{~m}$. Flowering: January to April; fruiting: May to September.

Uses - Trees are planted as ornamentals. The wood is suitable for beams, planks, and furniture. The fruits are eaten as vegetable or in jellies. The bark is used against diarrhoea.

Specimens examined: Chevalier 30935, 35826, 35827, 36757, 39251, 39633 (P); Dau 85 (P); Fleury 30084 (P); Hiep 667 (P); Muller 994, 1711, 1971 (P); Pierre 44, 2038, 2040 (P); Poilane 1287, 5817, 6694, 11822, 12073, 24687, 30065, 32373, 40890 (P); Squires 775 (P); Vinot 29 (P).

\section{DIPTEROCARPACEAE}

Medium to large trees, usually with resin, buttressed, and often (if mature trees) with flaky or fissured bark. Some or most parts with a tomentum of fascicled hairs, or sometimes single or peltate hairs. Stipules present, paired, large or small, persistent or caducous, leaving small to amplexicaul scars. Leaves simple, alternate, margin entire or sinuate, often with domatia, venation pinnate, tertiary veins scalariform or reticulate. Inflorescences panicles or racemes, rarely cymose, terminal or axillary. Bracts or bracteoles paired, small or large, persistent or caducous. Flower bisexual, actinomorphic, 5-merous. Calyx 2-5 sepals, persistent, usually greatly enlarging into wing-like lobes in fruit, sepals either free to base, imbricate in bud, or fused at base, forming a cup or tube enclosing the fruit, adnate to or free from it. Corolla 5-merous, contorted, base connate or free, usually hairy. Stamens usually numerous, filaments free or connate, anther 2-celled. Ovary superior or inferior, 3- rarely 2-locular, ovules 2 or 3 in each locule. Fruit indehiscent, 1-seeded, nearly always winged, wings 2-5. Nut enclosed between the grown calyx lobes (ovary superior) or under the calyx lobes (ovary inferior).

Distribution - Throughout the tropical regions of the world, mainly in South East Asia: c. 75 genera, 850 species. In Laos: 6 genera, 27 species. In Vietnam: c. 6 genera, c. 55 species. 


\section{KEY TO THE GENERA}

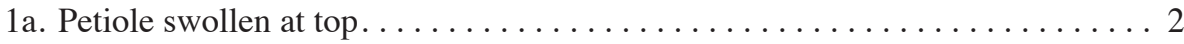

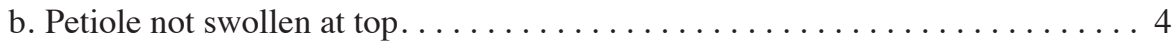

2a. Bark lamellated. Leaves in bud not folded, flat, intramarginal vein present...... $\ldots \ldots \ldots \ldots \ldots \ldots \ldots \ldots \ldots \ldots \ldots \ldots \ldots \ldots \ldots \ldots \ldots \ldots \ldots \ldots$.Anisoptera

b. Bark not lamellated. Leaves folded in bud, usually distinctly undulate between

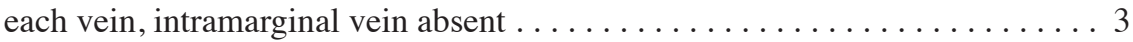

3a. Fruit with 2 large and 3 small or 5 much reduced wings. Stipules large, stipule scar

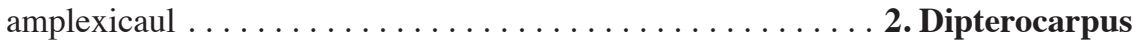

b. Fruit with 5 equal or nearly equal wings. Stipules small, stipule scar short, not amplexicaul ....................... Parashorea

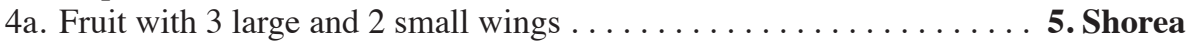

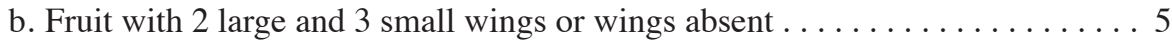

5a. Stilt roots absent. Tertiary venation reticulate, sometimes with glands at the junction of secondary veins . . . . . . . . . . . . . . . . . . . . . . .

b. Stilt roots present. Tertiary venation scalariform, glands absent. . . . . 3. Hopea

\section{ANISOPTERA Korth.}

Anisoptera costata Korth. - Fig. 16

Synonyms - Anisoptera cochinchinensis Pierre; A. oblonga Dyer; A. robusta Pierre

Vernacular names - Bak, Mai bak (L); Vên vên, Vên vên trắng, Vên vên xanh (V).

Large evergreen trees up to $40 \mathrm{~m}$ high, up to $1.7 \mathrm{~m}$ diam., bole straight, buttresses cylindrical, few, up to $4 \mathrm{~m}$ tall, thick, rounded, straight, continuing up the bole as ribs up to $10 \mathrm{~m}$. Bark greyish brown, glabrous when young, deeply fissured when old, outer bark thick, inner bark up to $3 \mathrm{~cm}$ thick, lamellated, cream-yellow. Sapwood creamwhite, heartwood pale yellow with silica. Twigs at first flat or angular, densely yellow stellately hairy, becoming minutely striated or smooth. Stipules c. $8 \mathrm{~mm}$ long, c. $3 \mathrm{~mm}$ wide, hastate, acute, early caducous. Petioles swollen, 2-4 cm long, hairy, thickened at top. Leaves elliptic to obovate, 6-20 by 3-11 cm, apex with a short obtuse point, base rounded or nearly cordate, glabrous on upper surface, stellate caducous tomentose on lower surface, venation pinnate, secondary veins 15-20 pairs, intramarginal vein present. Inflorescences a raceme, axillary or terminal, 10-15 cm long, stellate hairy. Sepals 5, tomentose, lobes triangular. Petals 5, obtuse, narrow elliptic, cream-coloured. Stamens 25-35, anthers oblong, tapering apically. Ovary cylindrical, 2-locular, ovules 2 in each locule, style short, pubescent at base. Fruit subglobose, brown, 1-1.5 cm diam., style persistent at top, two fruit-wings large, $10-16$ by $1-1.5 \mathrm{~cm}$, and the three others shorter, $1.5-2.5$ by $0.2-0.5 \mathrm{~cm}$.

Distribution - Indochina, Thailand, Malesia. In Laos: Vientiane, Bolikhamsai, Savannakhet, and Champassak provinces. In Vietnam: Kon Tum, Gia Lai, Dac Lac, Bien Hoa, Bà Ria-Vung Tàu, Ninh Thuân, Quang Nam-Dà Nang, Long An, Tây Ninh, Dông Nai, Hô Chi Minh, and Kiên Giang provinces.

Habitat \& Ecology - In moist or slightly dry forests, sometimes gregariously growing in pure stands. Usually mixed with Dipterocarpus spp. and Shorea species. Flowering: November to March; fruiting: February to May. 


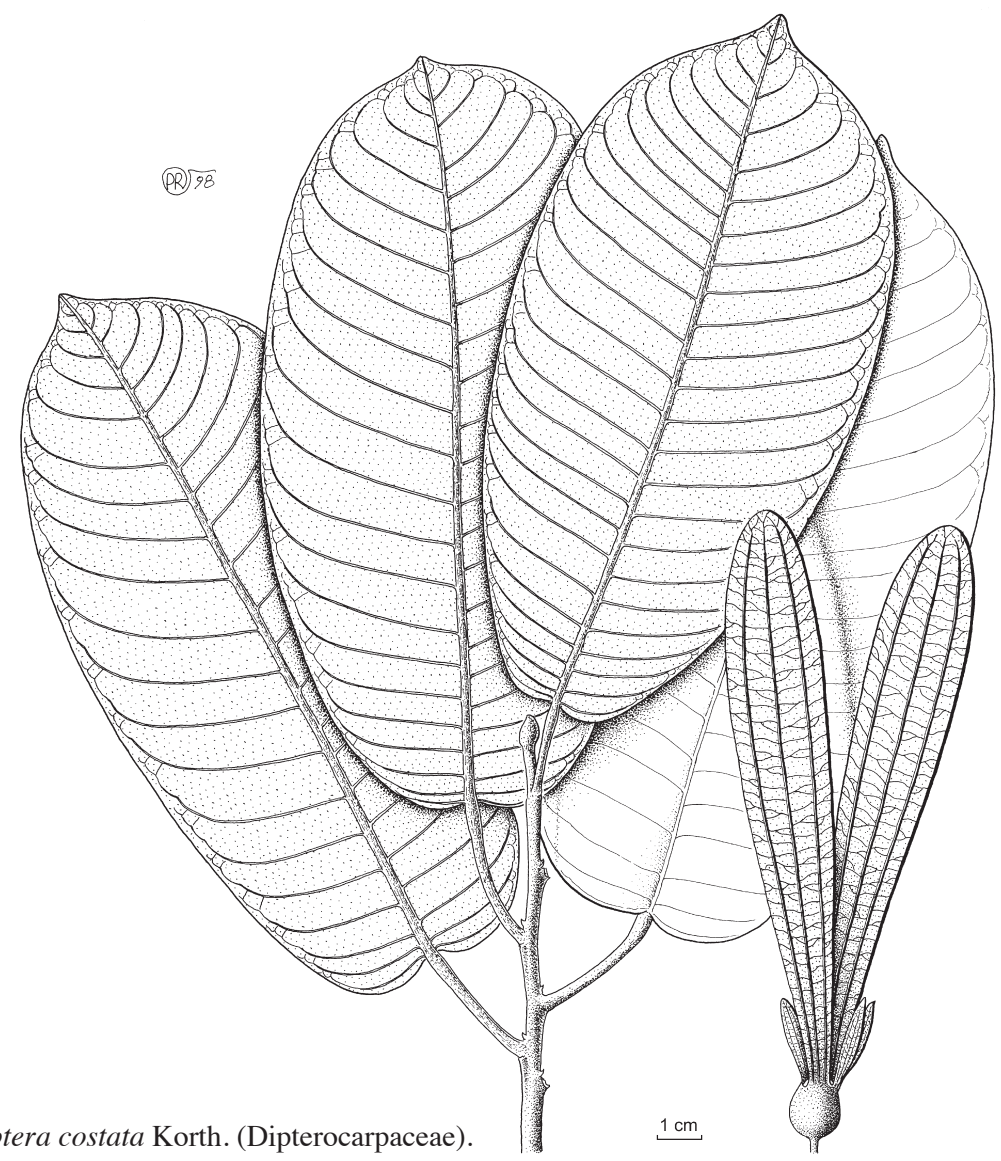

Fig. 16. Anisoptera costata Korth. (Dipterocarpaceae).

Uses - Wood whitish yellow with indistinctive sapwood and heartwood, used for making interior furniture, flooring, ship planking, veneer, and plywood. Resin from wood soft at first, then become hard, grey, strongly smelling.

Specimens examined: D'Alleizette s.n. (L); Aubreville 3 (L); Bodeuneuve $36800(\mathrm{P})$; Chevalier 35742, 35813, 36580, 39176 (P); Fleury 29935 (P); Forestier 36855 (P); Hoi 234 (P); Kerr 9543, 10042, $17029(\mathrm{~L}), 20736(\mathrm{P})$; Lefèvre $325(\mathrm{P})$; Manein $32(\mathrm{P})$; Parreau $174(\mathrm{P})$; Pierre 149, 1549 , 1565, 1566, 1571 (P); Poilane 830, 12057, 12067 (L, P), 7516, 11724,11881 (P); Put 642 (L); Sigaldy $44(\mathrm{P})$; Thorel 727, $2696(\mathrm{P})$; Tremessaignes $36734(\mathrm{P})$; Vidal $1281(\mathrm{P}), 4419(\mathrm{~L}, \mathrm{P})$.

\section{DIPTEROCARPUS C.F. Gaertn.}

\section{KEY TO THE SPECIES}

1a. Leaves ovate to elliptic, 14-25 cm long. Stipules greyish yellow. Fruit globose, with 5 ridges up to $8 \mathrm{~mm}$ broad, 2 larger wings $10-14 \mathrm{~cm}$ long. . . 1. D. alatus

b. Leaves broadly elliptical, 16-40 cm long. Stipules red. Fruit subglobose, without

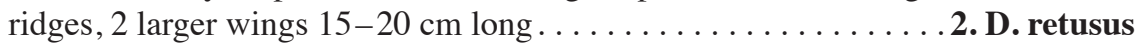




\section{Dipterocarpus alatus Roxb. \& G. Don - Fig. 17}

Synonyms - Dipterocarpus gonopterus Turcz.; D. incanus Roxb.; D. lemeslei Vesque

Vernacular names - Nhang, Nhang khao (L); Dầu rái, Dầu con rái, Dầu nước (V).

Large trees up to $45 \mathrm{~m}$ high, up to $1.5 \mathrm{~m}$ diameter. Trunk cylindrical, straight. Crown umbrella-like. Bark whitish grey, inner bark yellowish brown, resinous. Leaves ovate to elliptic, $14-25$ by $6-15 \mathrm{~cm}$, folded in bud, usually distinctly undulate between each vein, base cuneate to rounded, margin entire or undulate, apex acute or acuminate, secondary veins 11-20 pairs, prominent beneath, tertiary venation scalariform, sparsely pubescent above, densely pubescent beneath. Petioles swollen at top, $2.5-4 \mathrm{~cm}$ long, densely hairy. Stipules greyish yellow pubescent, stipule scar amplexicaul. Inflores-

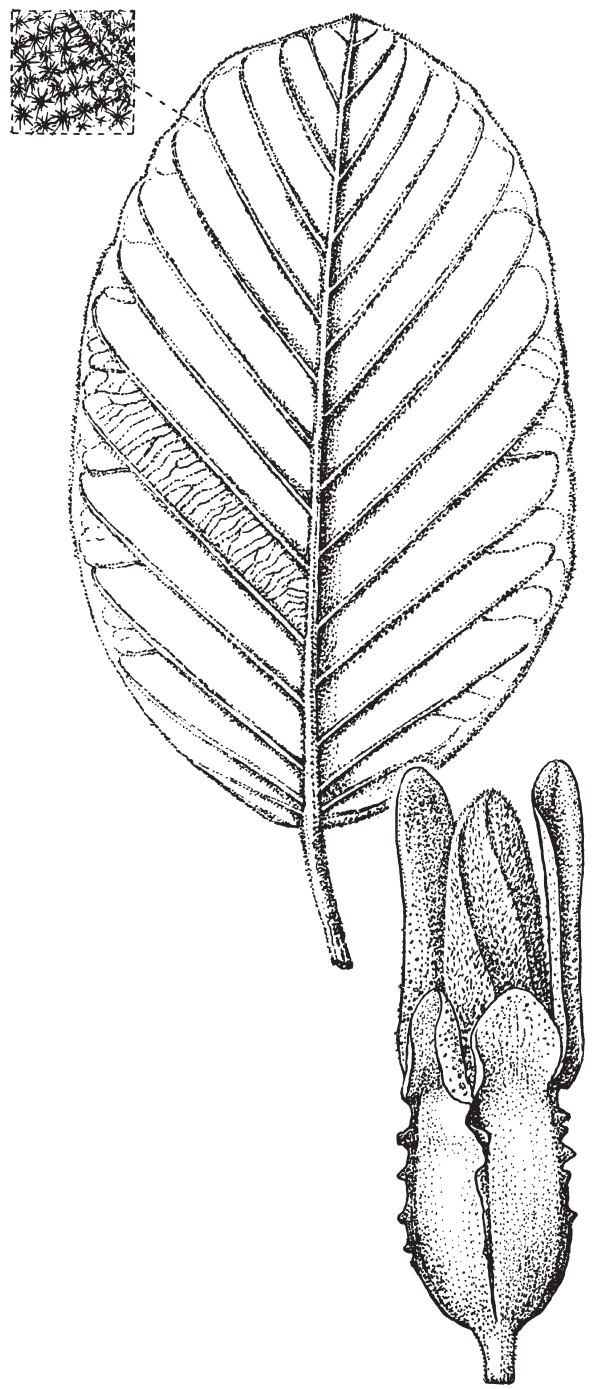
cences axillary, racemes up to $12 \mathrm{~cm}$ long. Flowers bisexual, pale pink; sepals 5; petals 5; stamens about 30. Ovary superior, ovoid, densely hairy, 3-locular. Fruit globose, with 5 ridges $8 \mathrm{~mm}$ broad, 2 larger wings $10-14$ by $2-3 \mathrm{~cm}$, three smaller ones $1-1.4$ by $1-1.3 \mathrm{~cm}$, wings red when young.

Distribution - India and South East Asia. In Laos: Vientiane, Savannakhet, Saravane, and Champassak provinces. In Vietnam: from Quang Nam-Dà Nang province southwards, most common in Dông Nai, Long An, and Bà Ria-Vung Tàu provinces .

Habitat \& Ecology - Tropical evergreen or monsoon forest, altitude below $800 \mathrm{~m}$, mainly 200-500 m, often growing gregariously in small pure stands along streams and river banks. Usually mixed with Dalbergia cochinchinensis, Dipterocarpus turbinatus, Pterocarpus macrocarpus, and Sindora siamensis. Light demanding tree, but shade tolerant when young. Natural regeneration is good, especially along rivers or on moist, flat land. Flowering: November, December; fruiting: April, May.

Fig. 17. Dipterocarpus alatus Roxb. \& G. Don (Dipterocarpaceae). 
Uses - A very common timber tree in South Vietnam. Wood rather hard with fine grains, easy to saw and polish. Used in light construction, for furniture and household implement. Its resin is used in the paint industry. This species is a very common shade tree in Hô Chi Minh city and in many towns of the southern provinces. Also planted in Hà Nôi capital from the beginning of this century.

Specimens examined: Abriae 35773 (P); D'Alleizette s.n.(L); Boudeneuve 36797 (P); Chevalier 30589, 36783, 36847, 37284, 39150 (P), 31351 (L, P); Evard 786 (P); Fleury 29936 (P); Forestier 35757 (P); Lefèvre 594 (P); Pierre 1693 (L, P), 1717, 5047 (P); Poilane 555 (P), 9520 (L, P), 11566 (L); Robinson 1350 (L), 1351 (P); Schmid s.n. (P); Thorel 962 (P); Vinot 36 (P).

\section{Dipterocarpus retusus Blume - Fig. 18}

Synonyms - Dipterocarpus macrocarpus Vesque; D. pubescens Koord. \& Valeton; D. tonkinensis A. Chev.

Vernacular names - Mai nhang dong, Nhang dong, Pak munung (L); Chò nâu, Chò nến (V).

Large deciduous trees up to $40 \mathrm{~m}$ high, $1 \mathrm{~m}$ diameter. Trunk straight, cylindrical. Bark of trunk and branches densely lenticellate. Twigs covered with dense, caducous hairs. Leaves broadly oval $16-40$ by $7-25 \mathrm{~cm}$, coriaceous, folded in bud, usually distinctly undulate between each vein, base rounded or cordate, margin entire or undulate, apex obtuse, leaf blade glabrous on both surfaces, midrib densely hairy, secondary veins 15-20 pairs, prominent beneath, densely covered with stellate hairs, tertiary venation scalariform. Petioles swollen at top, $2.5-4 \mathrm{~cm}$ long, pubescent when young, glabrous and blackish when mature. Stipules large, red, 8-12 cm long, stipule scar amplexicaul. Inflorescences axillary, panicles to 10 $\mathrm{cm}$ long. Flowers bisexual, bud 3 by $1 \mathrm{~cm}$. Calyx tube subglobose, 2.5 by $2 \mathrm{~cm}$. Sepals 5 . Petals 5 . Stamens 30, exceeding style at anthesis, filament short, anthers long, linear, tapering. Ovary ovoid, densely pubescent, 3-locular. Fruits subglobose, 2-3 cm diam., smooth, without ridges, 2 large wings $15-20$ by $2-3 \mathrm{~cm}$, with prominent veins, other 3 wings much reduced, auricular, about 5-8 mm long, wings red when young.

Distribution - India, Myanmar, Indochina, Thailand, Malaysia, Indonesia. In Laos: Vientiane province. In Vietnam: in the north, Tuyên Quang, Vinh Phu, Hà Tây, Bac Thai, and Hà Bac provinces. Nowadays this species is planted in many provinces in the north of Vietnam.

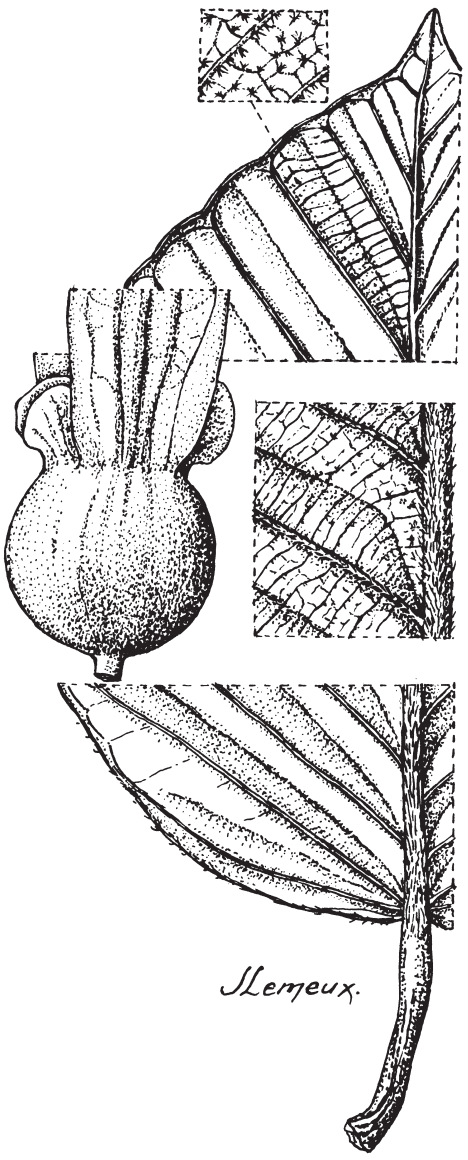

Fig. 18. Dipterocarpus retusus Blume (Dipterocarpaceae). 
Habitat \& Ecology - Tropical evergreen or monsoon forest, altitude100-1000 m, mainly 300-700 m, on loam, deep, fertile, and well-drained soils. Usually mixed with Magnolia conifera, Michelia mediocris, Parashorea chinensis, and Terminalia myriocarpa. Natural regeneration is good in secondary forest. Flowering: January, February; fruiting: April to July.

Uses - The wood is soft, susceptible to termite and insect attack. Used for construction and making furniture. Can be planted as an ornamental and shade tree along streets or in parks.

Specimens examined: Brillet s.n. (P); Chevalier 4028, 37386, 37387, 37521, 41028 (P), 37546 (L), 38004, 41029 (L, P); Fleury 37546 (P); Forestier 39699 (P); Gilbert 38039, 39716 (P); Kerr 18753 (L), 21242 (L, P); Pételot 1026 (P); Pierre 8408 (P); Van Beusekom 195 (L); Vidal s.n. (P).

\section{HOPEA Roxb.}

\section{KEY TO THE SPECIES}

1a. Bark greyish brown. Twigs glabrous. Leaves glabrous on both surfaces. Fruit $1-1.5$ $\mathrm{cm}$ diam., two larger wings $6-10 \mathrm{~cm}$ long . . . . . . . . . chinensis

b. Bark blackish brown. Twigs covered with the grey stellate hairs. Lower leaf surface with domatia at the axils of secondary veins. Fruit $0.6-0.8 \mathrm{~cm}$ diam., two larger wings $4-7 \mathrm{~cm}$ long

2. H. odorata

\section{Hopea chinensis (Merr.) Hand.-Mazz. - Fig. 19}

Synonyms - Hopea hongayensis Tardieu; Shorea chinensis Merr.

Vernacular names - Khen si (L); Sao hòn gai, Táu mặt quỉ (V).

Large evergreen trees up to $40 \mathrm{~m}$ high, $60 \mathrm{~cm}$ diam., stilt roots usually present. Bark greyish brown, when old peeling off in large pieces, leaving concentric rings on the trunk. Twigs glabrous, blackish brown when dry. Leaves narrowly ovate, 9-21 by 3-6 $\mathrm{cm}$, glossy-green above, paler beneath, glabrous on both surfaces, base rounded, margin entire, apex 1-2.5 cm long, pointed, midrib slightly evident above, and clearly evident beneath, secondary veins 7-10 pairs, curved near the margin. Petioles $0.6-1 \mathrm{~cm}$ long. Inflorescences axillary, panicles, $8-10 \mathrm{~cm}$ long, consisting of many branches, with 3 or 4 flowers. Flowers bisexual, pedicel very short. Sepals 5, imbricate, triangular. Petals 5, contorted, 7-9 mm long, glabrous inside, pubescent outside. Stamens 15, filaments flat, $1 \mathrm{~mm}$ long, often connected with the petals, anthers $2 \mathrm{~mm}$ long, connective 1-1.5 mm long. Ovary superior, ovoid, with stylopode, 3-locular, style short, stigma obtuse. Fruits ovoid, glabrous, $1-1.5$ by $0.6-1 \mathrm{~cm}$, two larger wings, $6-10$ by $1.4-1.7 \mathrm{~cm}$, with 9-13 parallel veins, 3 small wings, $6-8$ by $4-6 \mathrm{~mm}$, wings pink when young.

Distribution - South China, Laos, Vietnam. In Laos: Louang Prabang, Xieng Khouang, Vientiane, Bolikhamsai, and Khammouane provinces. In Vietnam: Hà Bac, Quang Ninh, Lang Son, Tuyên Quang, Ninh Binh, and Nghê An provinces.

Habitat \& Ecology - Tropical evergreen forest, altitude below $950 \mathrm{~m}$. Usually mixed with Hopea mollissima, Vatica fleuryana, and Vatica odorata. Shade demanding when young, then gradually becoming light demanding when older. Natural regeneration very good. Flowering: June to October; fruiting: February, March. 


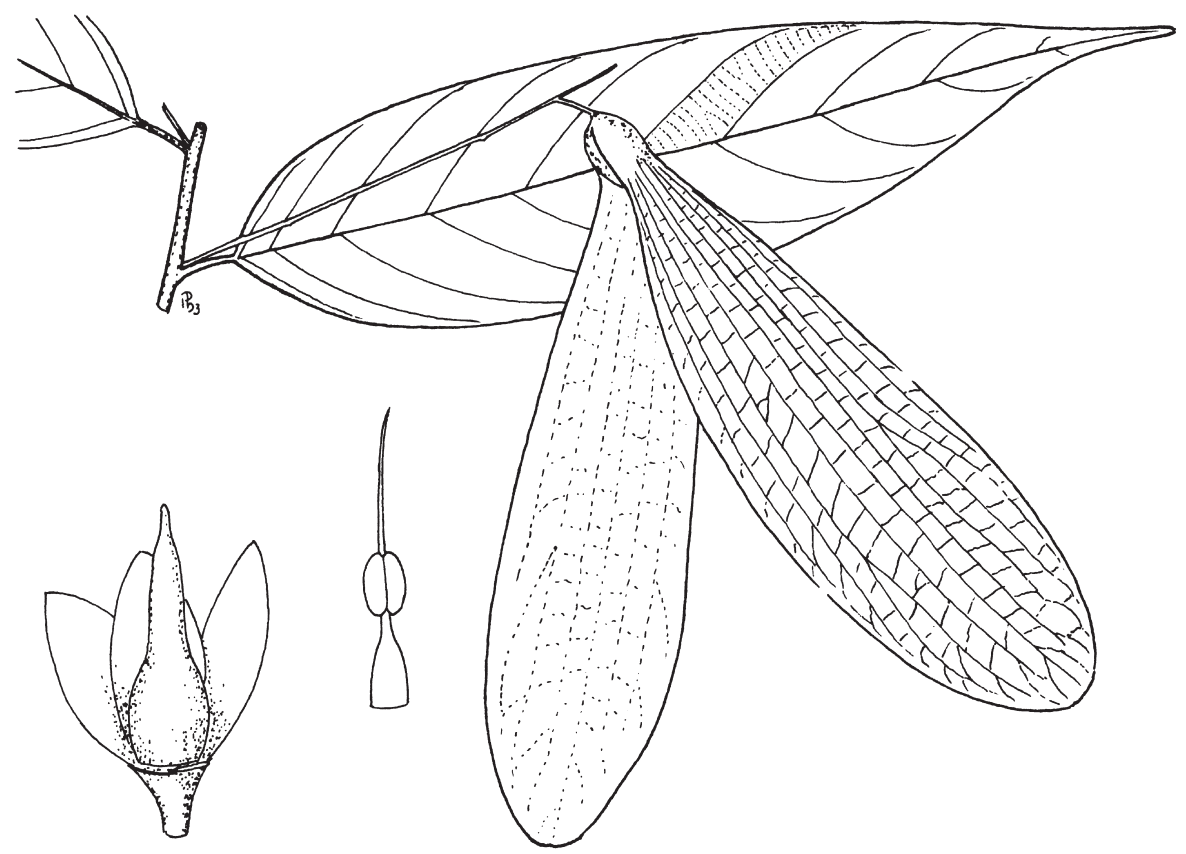

Fig. 19. Hopea chinensis (Merr.) Hand.-Mazz. (Dipterocarpaceae).

Uses - Timber hard, heavy, and resistant to termites and insects, used in house pillar making and in construction. (P).

Specimens examined: Bonnel s.n.(P); Casabianca 39628 (P); Tsang 27053, 27260, 30154, 30465

\section{Hopea odorata Roxb.}

Synonym - Doona odorata (Roxb.) Burck

Vernacular names - Khen, Khen hua (L); Sao, Sao đen, Sao cát, Sao nghệ, Sao xanh (V).

Large evergreen trees up to $40 \mathrm{~m}$ high, $80 \mathrm{~cm}$ diameter. Bole straight, cylindrical up to $25 \mathrm{~m}$ high, stilt roots usually present. Bark surface scaly, blackish brown, outer bark rather thick, inner bark dull yellow. Twigs and petioles covered with grey stellate hairs, later glabrous. Leaves ovate or elliptic, $8-14$ by $3-6 \mathrm{~cm}$, base broadly cuneate, unequal, margin entire, apex acute, secondary veins $8-12$ pairs, evident beneath, lower leaf surface with domatia at the axils of secondary veins, tertiary veins scalariform. Petioles 1-1.8 cm long. Stipules small, early caducous. Inflorescences axillary or terminal panicles, up to $17 \mathrm{~cm}$ long, hairy, consisting of many branches, with 3-9 flowers. Flowers bisexual. Sepals 5, hairy on both sides, outer 2 lanceolate, inner 3 broadly ovate. Petals pale cream-yellow, hairy outside. Stamens 15 , filaments slender, anthers narrowly ellipsoid. Ovary superior, ovoid, hairy. Fruits ovoid, 6-8 mm diam., 2 larger wings $4-7$ by $1-1.6 \mathrm{~cm}, 3$ shorter ones $3-4$ by $3-4 \mathrm{~mm}$. 
Distribution - Myanmar, India, Indochina, Thailand. In Laos: Xieng Khouang, Vientiane, Khammouane, Savannakhet, Champassak, and Attopeu provinces. In Vietnam: most provinces of southern Vietnam, from Gia Lai, Kom Tum provinces southwards. Recently this species is planted in many provinces in North and South Vietnam.

Habitat \& Ecology - Tropical evergreen forest, altitude below $600 \mathrm{~m}$. This species demands wet and deep soil. Natural regeneration is good under thin forest cover. Flowering: February, March; fruiting: April to July.

Uses - Wood is a good and valuable timber in Vietnam and Laos. The timber is hard, heavy, and resistant to termites and insects, used for making furniture, floors, and railway sleepers. Trunk contains much resin and gums. This species is planted as a shade tree in many cities in Vietnam.

Specimens examined: D'Alleizette s.n. (L); Bejaud 22999 (L); Chevalier 31751, 32032, s.n. (L); Collins 1400 (L); Kerr 15788, 17934, 19905 (L); Nimanthong 67 (L); Poilane s.n. (L); Put 608 (L); Vinol 19 (L).

\section{PARASHOREA Kurz}

\section{Parashorea chinensis H.C. Wang - Fig. 20}

Synonyms - Shorea chinensis (H.C. Wang) H. Zhu; S. wangtianshuea Y.K. Yang \& J.K. Wu

Vernacular names - Chò chỉ (V), Mạy hao, Mạy Khay (Mưòng, V).

Large trees up to $50 \mathrm{~m}$ high, $100 \mathrm{~cm}$ diam. (sometimes up to $200 \mathrm{~cm}$ ). Trunk cylindrical. Bark grey with slight longitudinal fissures, inner bark slightly aromatic, containing aromatic resins. Leaves elliptic to ovate, $7-20$ by $2.6-8 \mathrm{~cm}$, base rounded, margin entire, apex attenuate or shortly caudate, glabrous and shining on the upper side except on the veins, stellate hairy and with dot-like glands on the lower surface, folded in bud, usually distinctly undulate between each vein, secondary veins 13-20 pairs. Petiole 1-1.5 cm long, with stellate hairs. Stipules ovate, pointed at the top, cordate at the base, 2 embracing the twigs, with stellate hairs, stipule scar short. Inflorescences terminal or axillary panicles, 7-17 cm long, rhachis cylindrical, densely soft stellately hairy. Bracts ovate-oblong, $10-15$ by $5-6 \mathrm{~mm}$, usually 2 embracing the flower. Sepals imbricate, finely velutinous on both sides. Petals ovate, yellowish, with whitish indument outside. Stamens $12-15$, filaments 2-4.5 mm long, the inner whorl much longer, anthers $1.6 \mathrm{~mm}$ long, apiculate, inner ones shorter, anther prolongation 1-1.2 mm long, subulate. Ovary superior, ovoid, $3-5$ by $2-2.5 \mathrm{~mm}$, densely velutinous, 3-locular, ovules 2 in each locule, style glabrous. Fruits ovoid to ellipsoid, densely covered by grey scales, calyx lobes glabrous, a little bit unequal in length, embracing the fruit, 3 larger ones elliptical-oblong, $6-10$ by $1.2-2 \mathrm{~cm}, 5-7$ veins, the two smaller ones $3.5-7$ by $0.6-1 \mathrm{~cm}$.

Distribution - Endemic in South China and North Vietnam. In Vietnam: most provinces of North Vietnam from Lai Châu, Lào Cai to Quang Binh provinces, mainly in Hà Giang, Tuyên Quang, Kien Gian, Ninh Binh, Thanh Hoa, Nghê An, and Hà Tinh provinces.

Habitat \& Ecology - In Vietnam in valleys, along rivers, in evergreen forests, altitude 100-1000 m, but more often 300-700 m. Usually mixed with Aglaia gigantea, Dracontomelum dao, Pometia pinnata, Saraca dives, Terminalia myriocarpa, and Vatica odorata. Flowering: April to June; fruiting: July to September. 

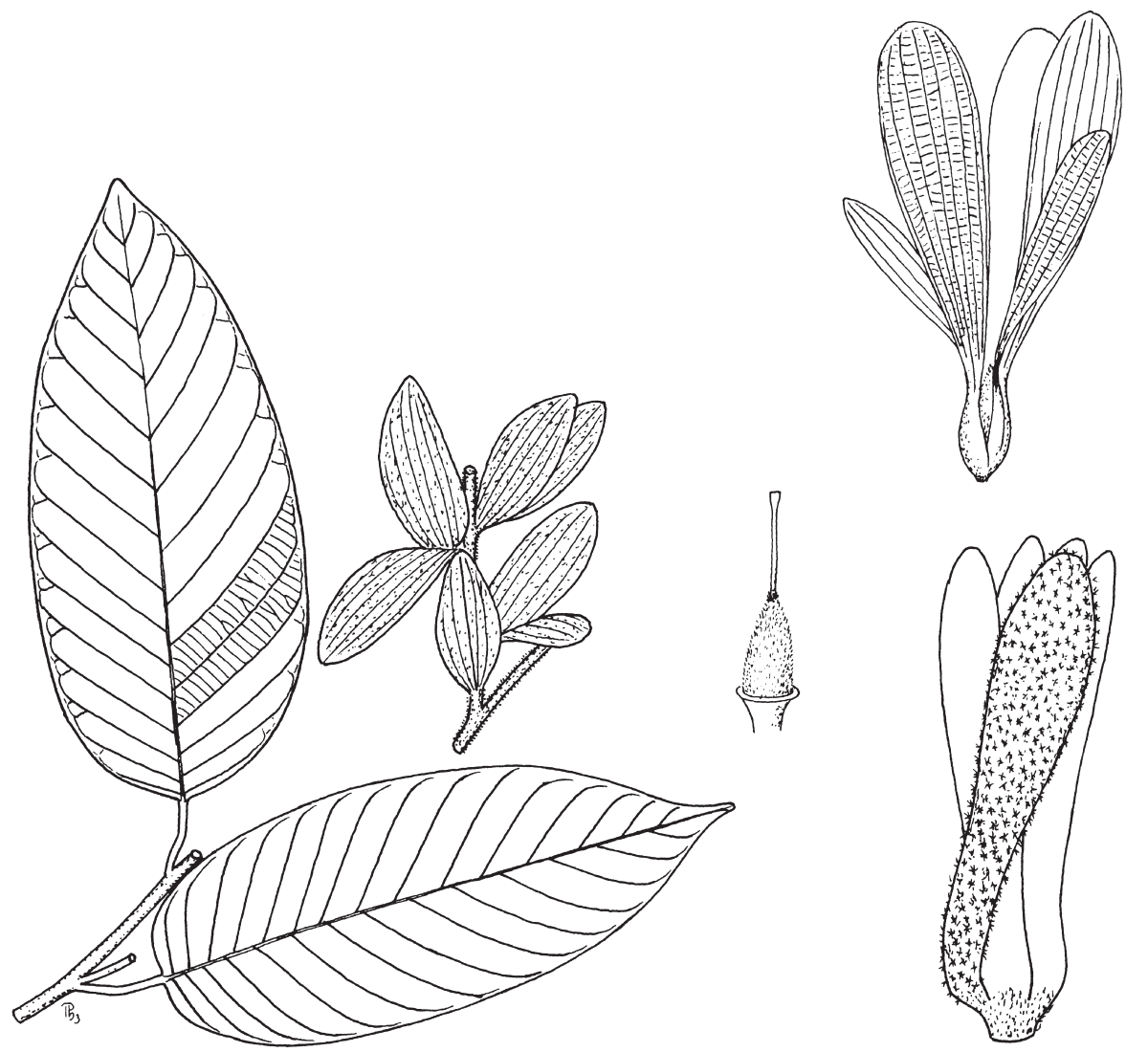

Fig. 20. Parashorea chinensis H.C. Wang Dipterocarpaceae).

Uses - The wood is hard, heavy, with a fine grain, yellow to pink, resistant against termite attack. The excellent wood is used for construction and making furniture. This species can be planted as shade tree along streets because of its beautiful shape.

Specimens examined: Cuong 275 (L); Dung s.n. (P); Favrot s.n. (P); Schmid s.n. (P).

\section{SHOREA Roxb. ex C.F. Gaertn.}

Shorea siamensis Miq. - Fig. 21

Synonyms - Pentacme siamensis (Miq.) Kurz; Shorea bracteata Pierre ex Laness.; S. mekongensis Pierre ex Laness.

Vernacular names - Hang (Vientiane, L), Pahu (Louang Prabang, L); Cẩm liên, Cà chắc xanh (V).

Large deciduous trees up to $30 \mathrm{~m}$ high, $80 \mathrm{~cm}$ diam. or more. Trunk straight. Bark grey, deeply fissured, $1.5 \mathrm{~cm}$ thick, inner bark reddish brown with yellowish brown resin. Leaves ovate or oval, $10-22$ by $7-16 \mathrm{~cm}$, base cordate, margin entire, apex obtuse or 
acuminate, young leaves reddish brown with stellate hairs, mature leaves usually dull green, glabrous above, tomentose or glabrous beneath, secondary veins $10-16$ pairs, raised beneath, tertiary venation scalariform. Petioles swollen, $2-4 \mathrm{~cm}$ long, slender and slightly flattened. Stipules 1-2 cm long, narrowly ovate, falling early. Inflorescences a terminal or axillary raceme, up to $20 \mathrm{~cm}$ long. Flowers bisexual. Sepals 5, red, narrowly ovate, hairy outside. Petals 5 , with recurved tips, fused at base and falling together as a rosette. Stamens 15 in two whorls, 10 in outer and 5 in inner whorl, filament short, anthers glabrous with long narrow tips, 5-6 mm long. Ovary superior, smooth, 3-locular, ovules 2 in each locule, style glabrous, 5-6 mm long, with single stigma. Fruit ovoid, 3 larger wings $7-10$ by $1-1.5 \mathrm{~cm}, 2$ shorter ones $5-7$ by $0.8-1 \mathrm{~cm}$.

Distribution - Myanmar, Indochina, Thailand. In Laos: Louang Prabang, Xieng Khouang, Vientiane, Khammouane, Savannakhet, Saravane, and Attopeu provinces. In Vietnam: most provinces of southern Vietnam, especially in Quang Tri, Gia Lai, Kom Tum, Quang Ngai, Binh Dinh, Phu Khanh, Dac Lac, Lâm Dông, Ba Ria, Bien Hoa, Sai Gon, Tây Ninh, Phan Rang, and Phuoc Long provinces. Recently this species has been planted in many provinces in North and South Vietnam.

Habitat \& Ecology - Common in dry deciduous Dipterocarp forest in pure stands or mixed with Shorea obtusa and Terminalia species. A xerophytic tree, mainly grow-

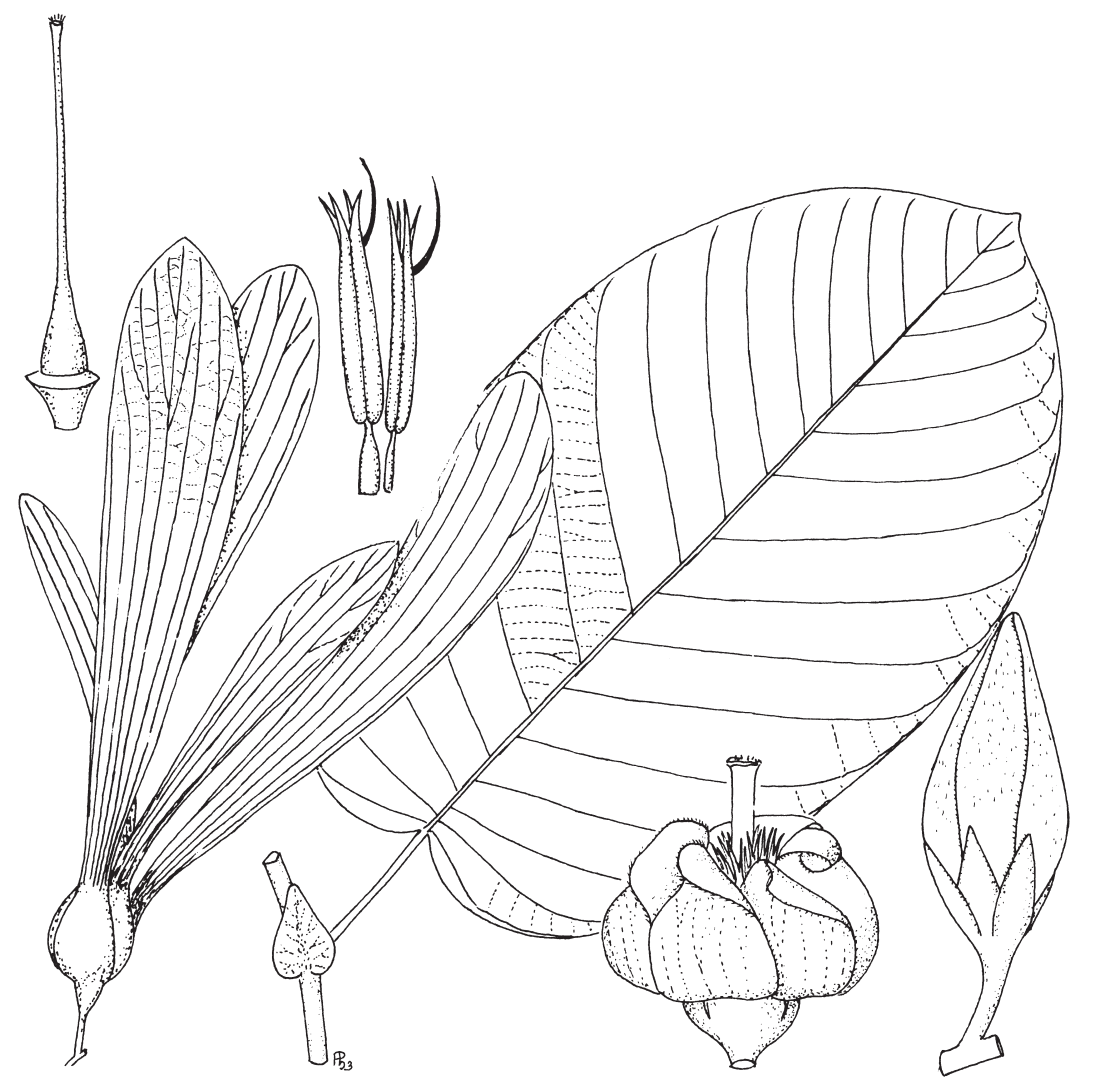

Fig. 21. Shorea siamensis Miq. (Dipterocarpaceae). 
ing on shallow poor, sandy, and stony soils. Shedding leaves in late February to early March. Flowering: February to April, before new leaves appear; fruiting: April, May.

Uses - Sapwood and heartwood distinctive. Sapwood red, heartwood brownish red, very heavy and solid. Used for long term construction and valuable furniture.

Specimens examined: D'Alleizette 717, s.n. (L); Chevalier 30030, 30953, 35769, 36578, 36586, 36655, 39147, 39148 (P), 35781 (L); Dournes 185 (P); Dussaud 41 (P); Forestier 35771, 36857, 40918 (P); Harmand 1336 (P); Hiep 369 (P); Millet 38405, 38406 (P); Pierre 649 (L), 796 (L, P); Poilane 1346, 8928, 9143, 9613 (P), 13740 (L, P); Schmid 912 (P); Thorel 3096 (P); Tixier 15 (P); Vidal 714, 814, 1285 (P); Vinot 35789 (P).

\section{VATICA L.}

Vatica odorata (Griff.) Symington - Fig. 22

Synonyms - Sunaptea odorata Griff.; Vatica fleuryana Tardieu; V. tonkinensis A. Chev.

Vernacular names - Chik dong, Si daeng (L); Táu (V).

Large trees up to $40 \mathrm{~m}$ high, up to $1 \mathrm{~m}$ diameter. Bole straight, cylindrical. Bark grey, inner bark white, very fibrous. Young twigs, leaf buds and petioles densely persistently pale yellowish brown to fulvous tomentose. Buds ovoid, 2 by $1.5 \mathrm{~mm}$. Leaves elliptic to ovate, $4-16$ by $2-5.5 \mathrm{~cm}$, thinly coriaceous, base obtuse or cuneate, margin entire, apex acuminate, secondary veins $8-15$ pairs, prominent beneath, tertiary venation reticulate. Petioles 4-12 mm long. Stipules 3-8 mm long, caducous. Inflorescences terminal or axillary panicles, up to $10 \mathrm{~cm}$ long, hairy. Flower bud to $8 \mathrm{~mm}$ long. Calyx densely shortly pale grey-brown tomentose, sepals 5, tomentose on both sides. Petals 5 , hairy to glabrous, twisted when young. Stamens 12 , connective obtuse. Ovary superior, hairy, 3-locular, 1 ovule per locule, style long, stigma divided into 3 triangular lobes. Fruits globose, tomentose, style persistent, two larger wings $4-6.5$ by $1-2 \mathrm{~cm}$, with 5 parallel veins, 3 shorter ones $1-1.5$ by $0.3-0.4 \mathrm{~cm}$.

Distribution - Myanmar, Indochina, Thailand, Malesia. In Laos: Vientiane, Savannakhet, Saravane, and Champassak provinces. In Vietnam: Tuyên Quang, Hà Giang, Lang Son, Bac Thai, Kiên Giang, and Quang Ninh provinces.

Habitat \& Ecology - Primary forests, altitude 300-900 m, slow growing, suitable for reforestation on (sandy) clay and sloping hill sides. Usually mixed with Castanopsis spp., Cinamomum spp., Machilus odoratissima, Madhuca pasquieri, and Garcinia cowa. Light demanding, natural regeneration is very prolific under a forest cover of 70-90\%. Flowering: May, June; fruiting: September, October.

Uses - Wood hard and heavy. Sapwood greyish white, heartwood brown. Timber valuable, resistant to termites and insects, much used in construction, making sleepers, bridges, ferry boats, and planks.

Note - Smitinand, Vidal \& Hô in Lecomte, Flore du Cambodge, du Laos et du Vietnam 25 (1990) 3 treated Vatica tonkinensis as Vatica mangachapoi Blanco subsp. obtusifolia (Elmer) Ashton, and Vatica fleuryana Tardieu as a synonym of Vatica diospyroides Symington. At this stage we are not able to make a decision with solid arguments, as we are unable to study the types and related material. This is the reason that we take a conservative view and treat these names as synonyms of $V$. odorata. 


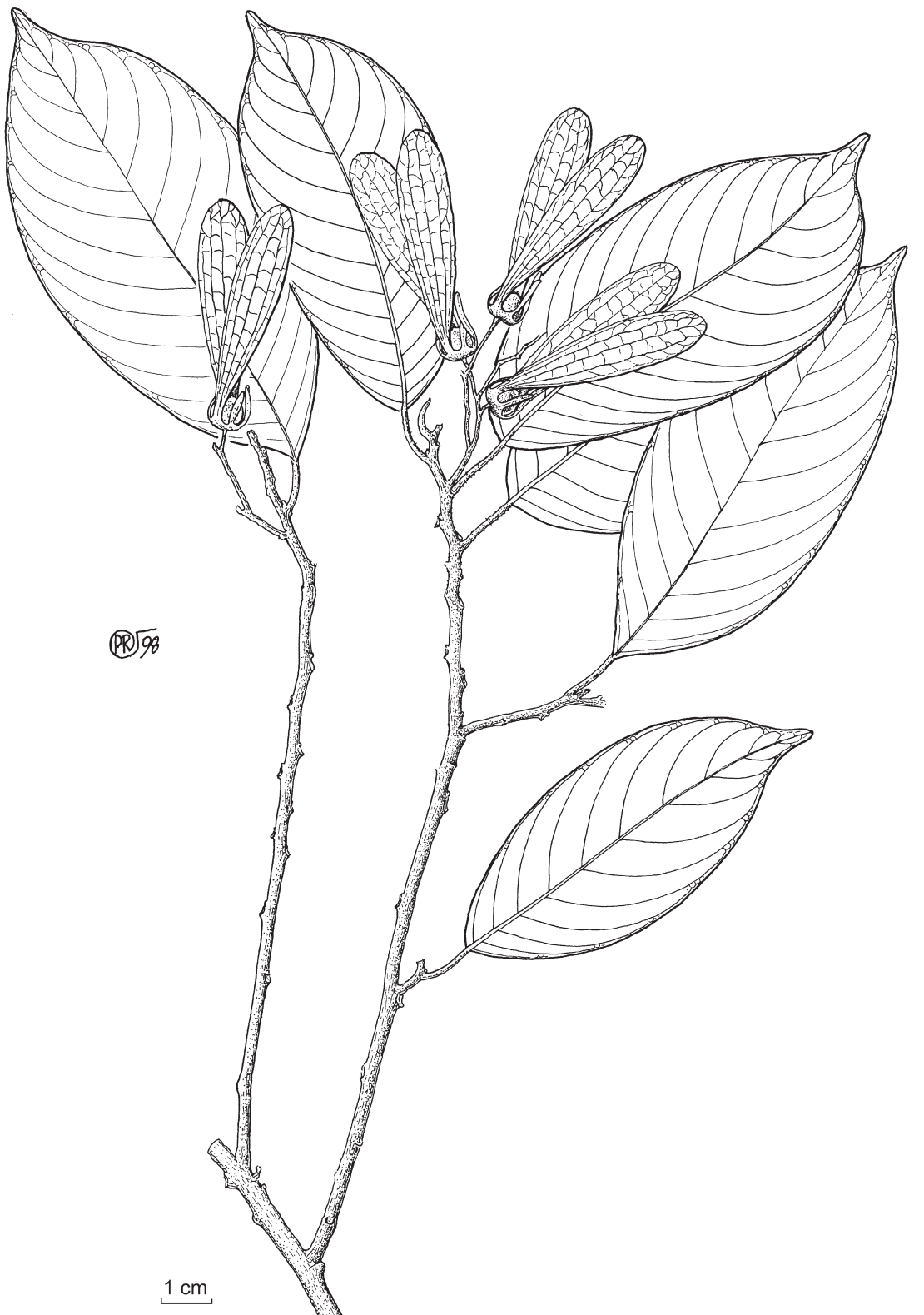

Fig. 22. Vatica odorata (Griff.) Symington (Dipterocarpaceae).

Specimens examined: D'Alleizette s.n. (L); Chevalier 31720, 31990, 36775, 39051, s.n. (L), 36780, 36785, 39195 (P), 38914 (L, P); Geesink et al. 7303 (L); Helfer 142, 716, 717 (L); Maxwell 76-193, 94-457, 94-674 (L); Pierre 173, 1577, 1578, 1583, 1584 (P), 1579 (L, P), $1580(\mathrm{~L})$; Poilane 11988, 13765 (P); Prumette 36833 (P); Vidal 1735, 2726, 6001 (P). 


\section{EBENACEAE}

Trees or shrubs, latex absent. Bark usually black, hard and brittle, with smooth, fissured, or cracked surface. Branches usually pseudowhorled. Leaves simple, alternate, drying yellowish, dark brown or black dots on one or both sides, margin entire. Stipules absent. Inflorescences cymose (with a basic cymose unit of 3 or 5 or 7 flowers, sometimes reduced to one flower, sometimes branches carrying multiple units). Flowers unisexual, regular, 3-5(-8)-merous. Sepals mostly united at base, sometimes free, the lobes imbricate or valvate, persistent in fruit. Petals basally united into a tube. Male flower: stamens (3-10)-20(-100), commonly inserted at base of corolla tube, sometimes on the receptacle, often in two whorls, filaments free or united in pairs, triads, or larger fascicles, or even into a single column, anthers basifixed, usually longer than the filaments, 2-locular, dehiscing by longitudinal slits. Pistillode present or absent. Female flowers: ovary superior, multilocular, 2-8 carpels as indicated by the number of styles or stigmas lobes, ovules pendulous, anatropous, bitegmic, staminodes reduced to a single whorl of sterile epipetalous lobes or absent. Fruit a berry, pericarp fibrous or fleshy, calyx persistent in fruit. Seed $(s) 1-16$, arranged in a single whorl around central axis, embryo straight or slightly curved, endosperm present.

Distribution - Worldwide: 2 genera, c. 500 species. Except for a few species of Euclea (in Africa) the bulk of the family belongs to Diospyros, which is almost completely tropical and subtropical, a few species occur in temperate climate. In Laos: only Diospyros with c. 15 species. In Vietnam: only Diospyros with c. 62 species.

\section{DIOSPYROS L.}

\section{Diospyros mun A. Chev. \& Lecomte}

Vernacular names - Nang dam (Northern, L), Lang dam (Vientiane, Savannakhet, L); Mun, Mùng, Mẹt (V).

Medium trees up to $18 \mathrm{~m}$ high, $40 \mathrm{~cm}$ diameter. Bole cylindrical, early branched. Bark black with shallow, longitudinally fissures. Crown dense. Leaves ovate, 7-10 by 3-5 $\mathrm{cm}$, base acute, apex acuminate, light green, venation pinnate, often with black glands below. Petiole slender, smooth, 0.8-1.2 cm long. Flowers unisexual. Male flowers in cymes in the axils of leaves, each bearing 3-5 yellow flowers, 4-merous, stamens 16, arranged into 2 whorls, filaments inserted on petals. Female flowers solitary, calyx cup-shaped, 4-merous, styles 3, bifurcate at the top. Fruit subglobose 1-2 cm diam., glossy-green, becoming black when mature, sepals 4, persistent. Seeds 6-8 arranged in a single whorl around the central axis.

Distribution - Indochina. In Laos: Vientiane and Savannakhet. In Vietnam: in the northern provinces: Hà Giang, Tuyên Quang, Lang Son, Hoa Binh, Ninh Binh, Thanh Hoa, Nghê An, Hà Tinh, Quang Binh, and Khanh Hoa (Cam Ranh Distr.) provinces.

Habitat \& Ecology - On limestone mountains, altitude below $800 \mathrm{~m}$. In the south on yellow ferralitic soil. Light demanding and drought tolerant tree, growing on poor soil. Slow growing, regenerations by seeds or suckers near the stump. Flowering: June to September; fruiting: July to November.

Uses - Very precious timber, heartwood black, hard and heavy, becoming glossy black when dry. Used for flower pots, statues, and especially for making chopsticks. 
Fresh seeds contain black dye for dyeing silk, cloth, and other materials. This species is rated as vulnerable in the Vietnam Red Data Book.

Specimens examined: D'Alleizette s.n. (L); Chevalier 34, 35887 (P); Fleury 30036 (P); Poilane $57,133,134,8779(\mathrm{P})$.

\section{EUPHORBIACEAE}

Herbs, shrubs, small, medium, or large trees, rarely climbers. Bark usually smooth, inner bark occasionally with white latex or watery sap. Leaves simple, mostly alternate, rarely opposite, sometimes palmate or lobed (Bischofia and Hevea). Stipules usually present, but often small and caducous; petiole often long, slender, swollen at the top and sometimes with glands near insertion with blade, venation of leaves pinnate or palmate. Flowers usually tiny, green, yellow, or white, in cluster, spikes, racemes or panicles, terminal or axillary, unisexual, dioecious or monoecious, structure of flowers extremely variable; sepals 2-5, overlapping or not; petals usually absent, or as many as sepals; disc often present; stamens 1 to many, free or variously fused; male flowers often with pistillode; ovary superior, 2- or 3-locular, 1 or 2 per locule, styles 2 or 3 , sometimes joined at base. Fruit typically a smooth, 3-lobed, woody capsule, splitting, often explosively into 3 or bivalved parts, or not lobed, or fleshy to leathery, not splitting and then often with a stone. Seeds always few, endosperm oily.

Distribution - Throughout the world except the coldest regions: c. 300 genera, 8100 species. This family is the sixth biggest family of flowering plants (after Orchidaceae, Compositae, Leguminosae, Gramineae, and Rubiaceae). In Laos and Vietnam: c. 62 genera, c. 416 species.

\section{KEY TO THE GENERA}

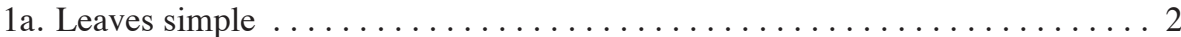

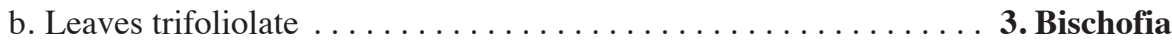

2a. Hairs simple, slash of the bark without sap. Petiole usually kneed at both ends.

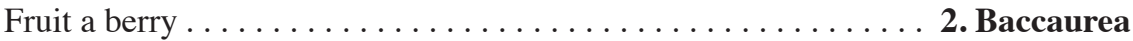

b. Hairs stellate, slash of the bark with sap. Petiole not kneed at the ends, fruit a

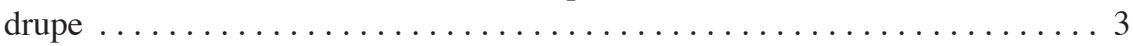

3a. Sap clear. Leaves usually bearing 2 crap-eye-shaped glands at the lower side of the base of the lamina. Bracts present. Petals absent. Fruit a small drupe, 1-2 cm diameter.................... Endospermum

b. Sap pinkish. Leaves bearing 2 glands at the upper side of the base of the lamina. Bracts absent. Petals present. Fruit a large drupe, $4-6 \mathrm{~cm}$ diameter 1.Aleurites

\section{ALEURITES J.R. Forst. \& G. Forst.}

\section{Aleurites moluccana (L.) Willd. - Fig. 23}

Synonyms - Aleurites ambinux Pers.; A. lobata Blanco; Jatropha moluccana L.

Vernacular names - Nam man (L); Lai (V). 
Trees up to $30 \mathrm{~m}$ high, up to $70 \mathrm{~cm}$ diameter. Trunk straight and cylindrical. Bark smooth, greenish grey, slash with watery, clear sap, inner bark pink. Branchlets angular, verticillate, covered with fulvous stellate, tomentose hairs. Leaves simple, alternate, crowded at the top of branchlets, $10-20$ by $5-17 \mathrm{~cm}$, broadly elliptic, or subrounded, margin often undulate or dentate, apex acute. Leaves of saplings or of lower branches 3-5-lobed, larger and with heart-shaped base. Petioles $6-12 \mathrm{~cm}$ long, bearing 2 globose, pink glands at the apex. Inflorescences panicles, terminal, branches widely spreading with slender peduncle. Male flowers: pedicels 10-12 mm long. Calyx tube with 2 or 3 irregular teeth, 2.5-3.5 mm long, apex obtuse, stellate tomentose outside. Petals 5, free, 5-7 mm long, pale yellowish white, narrow elliptic, with a hair tuft at the base.

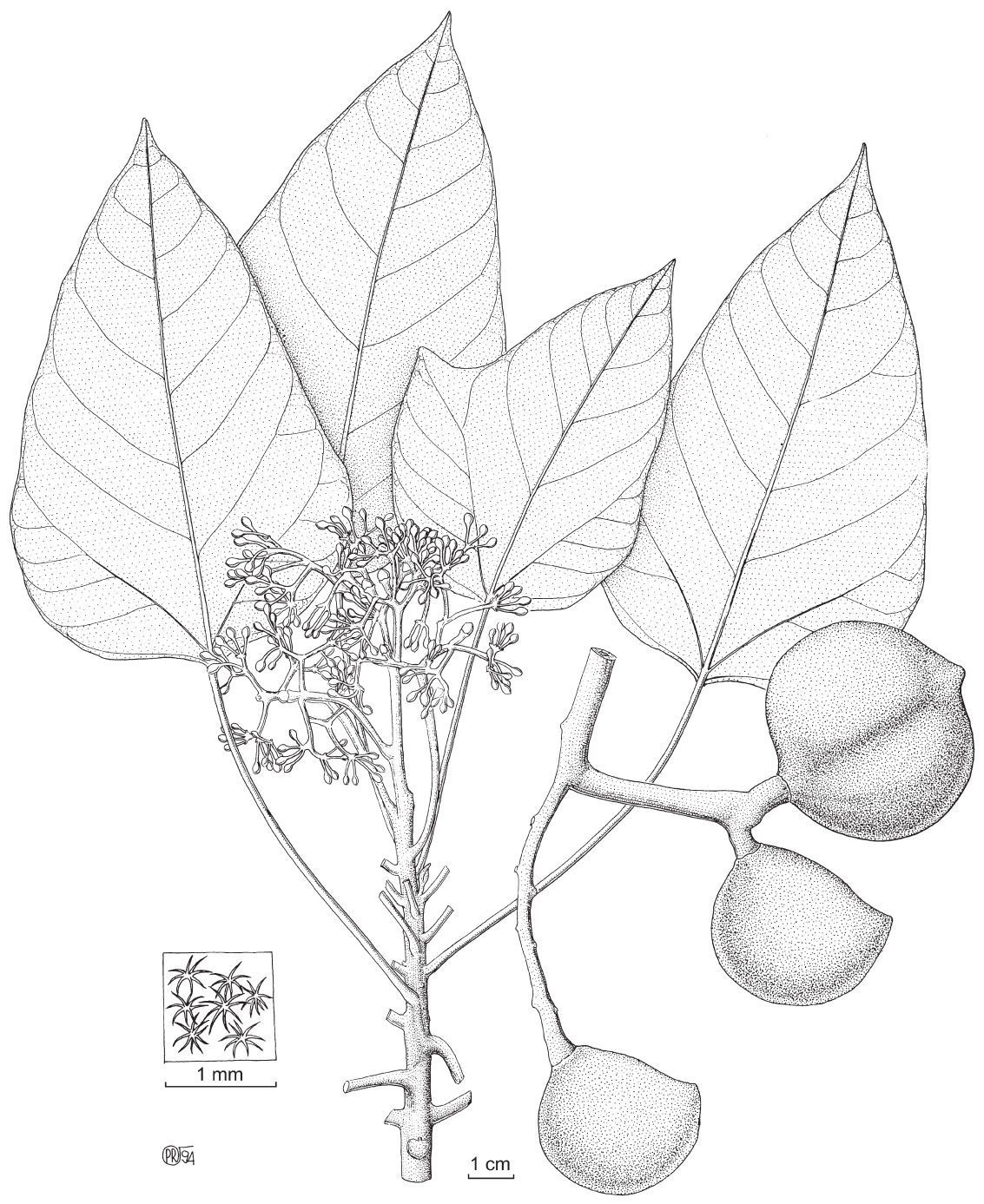

Fig. 23. Aleurites moluccana (L.) Willd. (Euphorbiaceae). 
Stamens 15-20, filament rolled in bud, anthers elliptic. Female flowers: pedicels bullate, 4-6 mm long. Calyx tube with 2 or 3 irregular teeth, 4-5 mm long, apex obtuse, stellate tomentose outside. Petals 5 , free, $8-10 \mathrm{~mm}$ long, pale yellowish white, oblong. Ovary ovoid, stellate tomentose, 2-locular, 2 ovules per locule, styles 2, deeply bilobed. Fruit globose, drupe, greenish yellow, 4-6 cm diam., with rufous stellate hairs. Seeds 2 in each locule, ovate, seed coat black, wrinkled, very hard, rich oil in endosperm.

Distribution - Originally from Malesia, but now also found in China, Thailand, India. In Laos: Vientiane province. Planted or naturally growing in many provinces from North to South Vietnam: in Cao Bang, Lang Son, Bac Thai, Hà Bac, Vinh Phu, Quang Ninh, Hoa Binh, Thanh Hoa, Nghê An, Dông Nai, and Tien Gian.

Habitat \& Ecology - Rain forest, monsoon forest or tall advanced secondary forest, on mountain slopes, very abundant on ridges, sometimes in sandy soil among granite boulders, loam soil or on former shifting cultivation lands, altitude below $300 \mathrm{~m}$. Light demanding and fast-growing tree, good regeneration by seed. Either flowering in June, July and then fruiting in August, September or flowering from February to March and then fruiting from December to February.

Uses - Wood white and soft with fine grain, susceptible to termite attach, used for general furniture. This species is cultivated for the oil obtained from its seed, which is liquid, fast drying and used in paint-mixing, soap production and as lamp oil. The fruit is edible, and the seed is mixed with curry in cooking and used as spice.

Specimens examined: Balansa 3287 (P); Bon 604, 2587, 2922 (P); Chevalier 29755 (P); Clemens 3858 (P); Eberhardt 3270, 4295, 5063 (P); Fleury 37903 (P); Forestier $14(\mathrm{P})$; King $258(\mathrm{~L})$; Mocret $375(\mathrm{P})$; Pierre $5291(\mathrm{P})$; Thorel $671(\mathrm{P})$; Tsang $27417(\mathrm{P})$.

\section{BACCAUREA Lour.}

\section{Baccaurea ramiflora Lour.}

Synonyms - Baccaurea cauliflora Lour.; B. oxycarpa Gagnep.; B. sapida (Roxb.) Müll.Arg.; Pierardia sapida Roxb.

Vernacular names - Dâu da đất, Du quả nhọn (V).

Trees up to $15 \mathrm{~m}$ high, up to $40 \mathrm{~cm}$ diameter. Bark orange-brown, inner bark often reddish brown. Branches (sub)glabrous. Leaves simple, alternate, blade elliptic to obovate $7-25.5$ by $3-8.8 \mathrm{~cm}$, papery, base attenuate to cuneate, margin entire, apex cuspidate, upper surface glabrous except for midrib, lower surface glabrous, veins 4-9 per side. Petioles 1-5 cm long, kneed at both ends. Stipules $2.5-6 \mathrm{~mm}$, pubescent, caducous. Inflorescences axillary to cauliflorous, racemes, densely covered with redfulvous pubescence, bracts triangular, 1.5-4 mm long. Male inflorescences up to 15.5 $\mathrm{cm}$ long, usually 3 flowers per bract. Male flowers $1.1-4 \mathrm{~mm}$ diam., yellow; pedicel 0.8-2.6 mm long; sepals 4 or 5, different in shape, 1-2.4 mm long, stamens 5-9, free, filaments $0.5-0.9 \mathrm{~mm}$ long, straight. Female inflorescences just below the leaves or really cauliflorous, up to $16 \mathrm{~cm}$ long, 1-3 flowers per bract. Female flowers $3-8 \mathrm{~mm}$ diam., yellow; pedicel 1.5-3 mm long; sepals 4 or 5, elliptic, 3.5-5 mm long; ovary (2-) or 3- or (4-)locular; ovules 2 per locule, stigmas sessile, not lobed. Fruits globose to ovoid berries, $19-32$ by $14-25 \mathrm{~mm}$, red to orange to pink to purplish outside, cream inside, (sub)glabrous outside. Seeds $9-15$ by $9-11 \mathrm{~mm}$; arillode white. 
Distribution - India (Andaman and Nicobar Islands), Myanmar, China (Yunnan, Hainan), Indochina, Thailand, Peninsular Malaysia. In Laos: Louang Prabang, Vientiane, Savannakhet, and Xieng Khouang provinces. In Vietnam: almost all provinces.

Habitat \& Ecology - Primary or secondary rain forest, altitude below $1000 \mathrm{~m}$, often cultivated on soil, sand, granite, moist and well-drained, along stream banks, in valleys, or on hill sides. Usually mixed with Deutzianthus tonkinensis, Dracontomelum dao, Phoebe spp., and Pometia pinnata. Flowering: March, April; fruiting: August, September.

Uses - Wood used for making furniture and agricultural implements. Arillode edible, sweet to sour.

Specimens examined: D'Alleizette 6431 (L); Balansa 3275 (L, P), 3276, 4757 (P); Chevalier 31902, 37416 (P); Clemens 4354 (P); Contest 300 (P); Dong 150 (P); Eberhardt 2684, 2702, 2767, 3043, 3917, 4580 (P); Fleury 30118, 32043, 37435 (P); Kerr 2493, 21280 (L); Nidegene 2081 (P); Pételot 4689, 4699 (P); Pierre 53, 145, 186, 395, 6276 (P); Poilane 1109, 1271, 10523, 11175, 11696, 12275, 20496 (L, P), 11964, 12041, 13661, 20094 (P); Soejarto et al. 10269 (L), 10567, 10659 (P); Thorel 770, s.n. (P); Tsang 29136 (L, P); Vidal 1428, 2009 (P);

\section{BISCHOFIA Blume}

Bischofia javanica Blume - Fig. 24

Synonym - Bischofia trifoliata Hook.

Vernacular names - Khom fat (Louang Prabang, L), Foung fat (Xieng Khouang, L); Nhội (V).

Trees up to $40 \mathrm{~m}$ high, up to $1.5 \mathrm{~m}$ diameter. Trunk straight, stout, and cylindrical. Bark pale brown or reddish brown, smooth, becoming darker and scaly with ages, inner bark brownish pink with red sap. Stipules papery, caducous. Leaves trifoliolate, alternate. Petioles 7-15 cm long; petiolules $0.5-1.2 \mathrm{~cm}$ long, end one 2-4 cm long; leaflets elliptic or ovate, $8-15$ by $5-9 \mathrm{~cm}$, cuneate at base, margin dentate, apex cuspidate, mature leaves leathery, dark green, smooth, old leaves red. Inflorescences panicles, axillary, dioecious, greenish yellow. Male inflorescences 7-20 cm long. Bracts lanceolate, 1-4 mm long, falling early. Pedicel 2-5 mm long. Sepals 5. Petals absent. Stamens 5, free, opposite sepals, filament short. Disc absent. Female inflorescences looser and less branched than the male, $15-30 \mathrm{~cm}$ long. Pedicel 4-6 mm long. Sepals 5, slightly fused at base. Petals absent. Ovary smooth, 3-locular, 2 ovules per locule, style very short with 3 long and spreading to recurved stigmas. Fruits globose, $0.5-1 \mathrm{~cm}$ diam., hanging in large clusters. Seed $(s) 1$ or 2 per locule, oblong, shiny, 4-5 mm long.

Distribution - India, South China, Thailand, Indochina, and throughout the Malesian areas (but rare in Peninsular Malaysia and large parts of Borneo). In Laos: Louang Prabang and Xieng Khouang provinces. In Vietnam: almost all provinces.

Habitat \& Ecology - Dense primary or secondary evergreen forest, altitude below $1000 \mathrm{~m}$. Growing on a wide range of soil type, such as well-drained clay soil, old basalt or alluvium soil of ravines and river bank. Natural regeneration is good. During the first year, scattered light is suitable for seedlings and young trees. Flowering: March, April; fruiting: May to December.

Uses - Timber heavy, sapwood brownish yellow, distinct from the reddish brown heartwood. Used for general construction, making furniture, doors, bridges, railway 


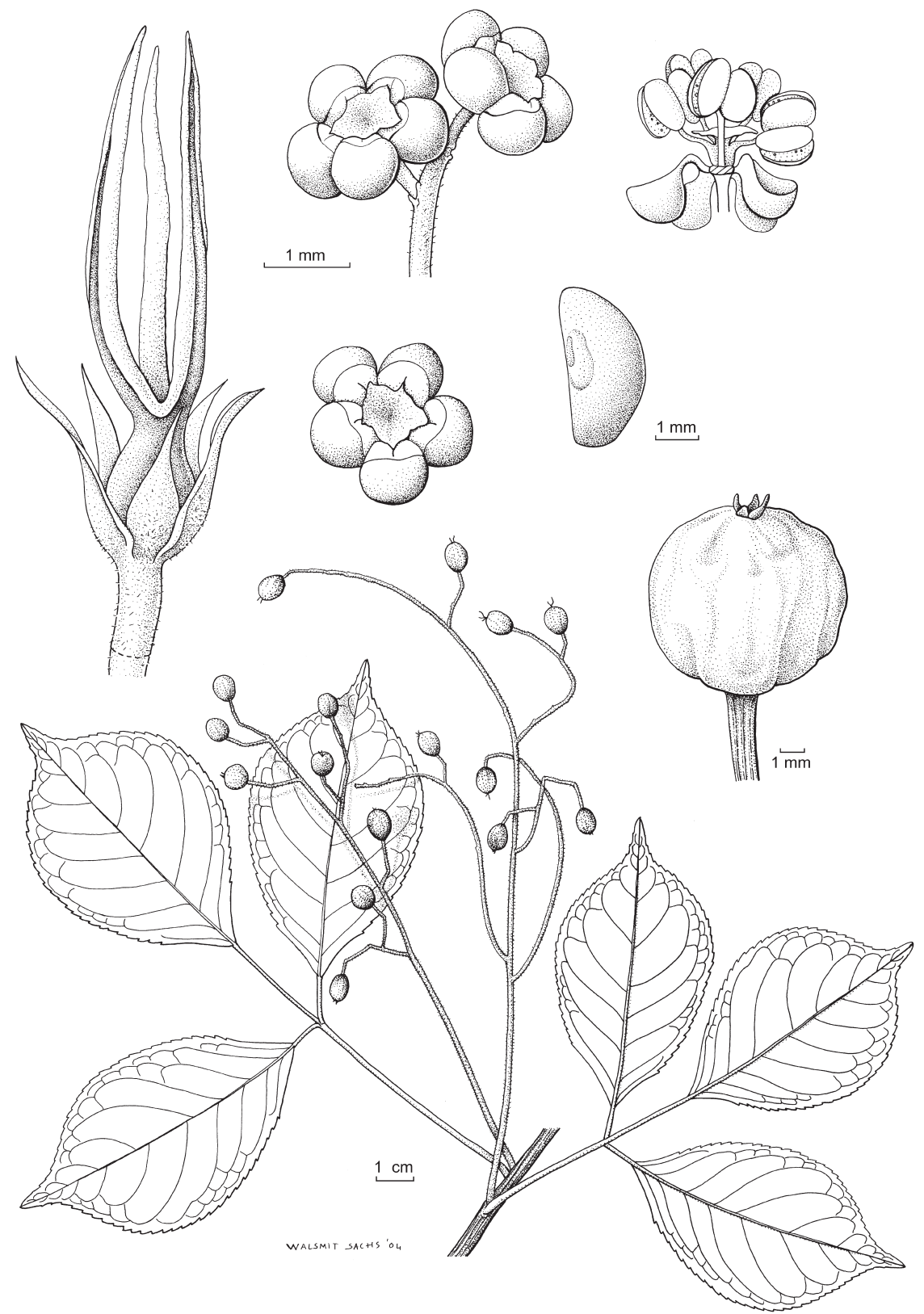

Fig. 24. Bischofia javanica Blume (Euphorbiaceae).

sleepers, mining props, and agricultural implements. The bark contains tannin, used for toughening nets and ropes. This species is very successfully planted along the roads and parks of many provinces in Vietnam. 
Specimens examined: Balansa 1501, 3966, 3967, 3968 (P); Bon 358, 431, 450, 875, 1424 (P); Chevalier 29759, 32191 (P); Fleury 30198, 37991 (P); Harmand 1885 (P); Hiep et al. $138(\mathrm{P})$; Hohenacker 1573 (L); Jaumatre 2714 (P); Master s.n. (P); Pierre s.n. (P); Poilane 1229, 1596, 2159, 2343, 4834, 6683, 10735, 11265, 91265 (P); Soejarto et al. $10350 b(\mathrm{P})$; Thomson s.n. (P); Tsang 27117 (P), 29206, 29933, 30319 (L, P); Vidal 775b, 1498 (P).

\section{ENDOSPERMUM Benth.}

\section{Endospermum chinense Benth.}

Vernacular name - Vạng trúng (V).

Trees up to $35 \mathrm{~m}$ high, up to $1 \mathrm{~m}$ diameter. Trunk straight, cylindrical. Bark yellowish grey with transversal rings around the trunk, inner bark white with watery sap. Twigs and petioles stellately tomentose. Stipules small, triangular, hairy. Leaves simple, alternate, young leaves cordate, $10-25 \mathrm{~cm}$ long, old leaves smaller, ovoid or nearly round, 8-15 by $5-13 \mathrm{~cm}$, base of lower surface with 2 crab-eye-shaped glands, margin entire, apex rounded, upper surface green, lower surface yellowish green, venation palmate, 3-5 secondary veins per side. Petioles 3-10 cm long, hairy. Flowers unisexual, dioecious. Male inflorescences panicles, up to $21 \mathrm{~cm}$ long, with branches up to $4 \mathrm{~cm}$ long. Calyx 4-lobed, pubescent outside, glabrous inside. Petals absent. Stamens 10, spirally arranged on an androphore, filaments free, anthers 4-celled. Female inflorescences racemose, up to $18 \mathrm{~cm}$ long. Sepals 4 or 5. Petals absent. Ovary globose, 2- or 3-locular, 1 ovule per locule, style very short, stigmas 2- or 3-lobed. Fruit a globose drupe, 1-1.5 cm diam., stigmas persistent.

Distribution - India, Myanmar, China (Hainan), Hong Kong, Vietnam, Thailand. In Vietnam: Bac Thai, Yên Bai, Vinh Phu, Hoa Binh, Quang Ninh, Hà Tây, Ninh Binh, Thanh Hoa, and Quang Tri provinces. In Laos: not yet recorded.

Habitat \& Ecology - Primary and secondary forest, often along streams and on water logged or on dry sandy soil, altitude 50-500 m. Usually mixed with Canarium spp. and Cryptocaria lenticellata. A light-demanding and fast-growing tree, deciduous during winter time. Natural regeneration is good under $50-60 \%$ forest cover. Flowering: May, June; fruiting: November, December.

Uses - Wood yellow-white, soft and light. Used for making matches, pencils, table tennis rackets, plywood, and general furniture.

Specimens examined: D'Alleizette 6531, s.n.(L); Chevalier 32260 (P); Fleury 30137 (P); Forestier s.n. (P); Poilane 141, 1296 (P).

\section{FAGACEAE}

Usually medium or big trees, rarely shrubs. Buttresses or stilt roots sometimes present. Crown deep, dense, domed, often with massive, more or less spreading branches, often grey or silvery from below. Bark usually grey, smooth with prominent lenticels often in lines, scaly or fissured, inner bark usually cream and brown, with much tannin, darkening on exposure, hard, firm, coarsely fibrous textured. Cambium often ridged and penetrated by hardwood rays. Indumentum consisting of simple, stellate or fascicled hairs. Stipules present, caducous or rather long persistent. Leaves simple, alternate, spirally arranged, distichous (a few species of Castanopsis), or crowded near the top of 
the twigs (species of Quercus), margin entire, denticulate, serrulate, crenate or lobed, venation pinnate. Inflorescences unbranched or branched, male and female separated or mixed. Male inflorescences erect or pendulous in the axils. Male flowers solitary or in dichasial clusters of 3-7(-30) along the rhachis, sessile. Sepals 4-6(-9), scalelike, connate or distinct. Stamens (4-)6-12(-15), filaments filiform, anthers reniform or ovoid, longitudinally dehiscent. Female inflorescences erect in the axils. Female flowers sessile, solitary or in dichasial clusters of 3-15 along the rhachis. Sepals 6, scale-like. Petals absent. Staminodes 6-12 or absent. Ovary inferior, 3-6(-9)-locular, 2 ovules per locule, styles as many as ovary locules, stigmas capitate (Quercus and Trigonobalanus) or punctiform (Castanopsis and Lithocarpus). Cupules solitary or in dichasial clusters along the rhachis, saucer- to cup-shaped or completely enclosing the fruit, at maturity indehiscent or splitting into 2-8 (or more) segments, external wall muricate, scaly, spiny, with concentric, spiral lamellae or rarely almost smooth. Fruits a 1-seeded nut, 1-4 nuts grouped within a cup (cupule). Seeds without endosperm, embryo and cotyledons large.

Distribution - In temperate and tropical regions but mostly in the northern hemisphere: c. 8 genera, more than 900 species. In Laos and Vietnam: c. 8 genera, c. 211 species.

\section{KEY TO THE GENERA}

1a. Deciduous trees. Leaf margin dentate. Stipules up to $1 \mathrm{~cm}$ long. Ovary 6-9-loculed. Capsules with 2 or 3 nuts, entirely covered with hard spines ..... 1. Castanea

b. Evergreen trees. Leaf margin entire or dentate. Stipules smaller than $4 \mathrm{~mm}$ long. Ovary 3-6-loculed. Capsules with 1 nut, entirely or partly covered with spines 2. Castanopsis

\section{CASTANEA Tourn. ex L.}

\section{Castanea mollissima Blume}

Synonyms - Castanea duclouxii Dode; C. fargesii Dode; C. hupehensis Dode

Vernacular names - Dẻ trùng khánh, Dẻ tàu, Dẻ trồng $(\mathrm{V})$.

Trees up to $25 \mathrm{~m}$ high, up to $1 \mathrm{~m}$ diameter. Trunk much branched, branches brown fulvous, with white scales. Twigs grey, tomentose, slender and densely arranged when old. Bark rough. Leaf buds small, ovate, tomentose. Stipules narrow ovate, c. $1 \mathrm{~mm}$ long, rather coriaceous persistent or caducous. Leaves simple, alternate, distichous, ovate or oval, rough, dry, thick, 14-20 by $5-7 \mathrm{~cm}$, base rounded, truncate or obliquely cordate, margin sparsely and irregularly serrate, apex acute to acuminate, sparsely white tomentose beneath when young, lateral veins 12-16 pairs, obviously evident beneath. Petioles glabrous or slightly tomentose, 0.7-2 cm long. Male inflorescence 8-20 cm long. Perianth scale-like. Stamens usually 10-12, slender. Female flowers densely arranged. Styles 7-9 mm long, erect or spreading, much tomentose. Cupule globose, $4.5-6 \mathrm{~cm}$ diam., entirely covered with acute and hard spines, over $1 \mathrm{~cm}$ long and stellately hairy, 2 or 3 nuts in each cupule. Seeds $2-3 \mathrm{~cm}$ diam., reddish brown, glabrous at the base, hairy at the top. 
Distribution - China and Vietnam. In Vietnam: Lào Cai, Cao Bang (Trung Khach), Lang Son, Lai Châu and many other provinces. In Laos: not yet recorded, but likely present.

Habitat \& Ecology - Altitude 500-2000 m. Light demanding, growing on waste land, stony, acid, or limestone soils. Natural regeneration is good. It can be planted under secondary forest cover. Flowering: February, March; fruiting: October to December.

Uses - Wood rather valuable, brownish with straight veins, gross and heavy. Used for construction, boat building, making agricultural tools and pit props. Seeds edible, contains much starch.

Specimens examined: Farges 820 (P); Kiang 1021 (P); Rock 4754, $6436(\mathrm{P})$.

\section{CASTANOPSIS Spach}

\section{KEY TO THE SPECIES}

1a. Leaves obovate, petiole 1-2 cm long. Cupule enclosing about half of the nut, scales arranged into many irregular bands . . . . . . . cerebrina

b. Leaves elliptic, petiole $0.4-1.3 \mathrm{~cm}$ long. Cupule enclosing the nut totally with long and hard spines

2. C. indica

\section{Castanopsis cerebrina (Hickel \& A. Camus) Barnett}

Synonym - Pasania cerebrina Hickel \& A. Camus

Vernacular names - Dẻ bốp, Sồi phảng, Sồi đen (V).

Trees up to $25 \mathrm{~m}$ high, up to $90 \mathrm{~cm}$ diameter. Trunk straight, young branches covered with dense reddish brown, simple and stellate hairs. Leaves distichous, obovate, 12-20 by $4-8 \mathrm{~cm}$, base cuneate, margin acutely and regularly serrate for $3 / 4$ of the length towards the top, apex acuminate, green above, reddish brown tomentose beneath, if mature almost glabrous, venation pinnate, lateral veins 10-20 pairs, curved at the margin, prominent on lower surface. Petiole 1-2 cm long, slightly tomentose. Male catkins 4-9 $\mathrm{cm}$ long, in branched panicles, usually terminal. Perianth puberulous. Anthers small, filament slender. Pistillode small, styles 3, divergent. Female inflorescences $5-11 \mathrm{~cm}$ long. Cupule cup-shaped, 1.8-2.5 cm long, 1.6-2.2 cm diam., enclosing about 1/2 the seed, densely hairy inside, slightly tomentose outside, scales acute, flat, arranged into many irregular bands, pedicel $4-5 \mathrm{~mm}$ long, solitary. Nut narrowly conical, $2-2.5$ by $1.4-1.8 \mathrm{~cm}$, tomentose, apex sometimes 3-angled.

Distribution - China (Southeast Yunnan), Indochina, North Thailand. In Laos: Louang Namtha province. In Vietnam: Hà Tinh, Nghê An, Thanh Hoa, Yên Bai, Tuyên Quang, Quang Ninh, Hà Bac, and Hà Tây provinces.

Habitat \& Ecology - On low hills or on the forest edge, altitude below $400 \mathrm{~m}$. Light demanding tree. Natural regeneration is good, germination rate very high, also in the nursery. Flowering: February to April, October, November; fruiting: March to June, October to December.

Uses - Wood hard, can be used for construction and making agricultural tools.

Specimens examined: Balansa 2380 (P); Fleury 30117 (P); Forestier s.n. (P); Pételot 1551, 4831 (P); Poilane 26264, 26315 (P); Toan 32A (L). 


\section{Castanopsis indica (Roxb. ex Lindl.) A.DC.}

Synonyms - Castanea indica Roxb. ex Lindl.; Castanopsis sinensis A. Chev.; C. subacuminata Hayata

Vernacular names - Ko ket, Ko lakai, Ko luay, Ko tang (L); Dẻ gai Ân Độ, Cà ồi (V).

Trees up to $30 \mathrm{~m}$ high, up to $1 \mathrm{~m}$ diameter. Bole straight. Crown broadly rounded. Bark brownish grey with dark grey traces, wrinkled, thick, grooved, inner bark much fibrous. Bud scales, young branchlets, petiole, leaf blades abaxially and rhachis of inflorescences densely covered with reddish brown hairs. Leaves elliptic $9-20$ by 3-9 $\mathrm{cm}$, base obtuse, margin acutely and regularly serrate for $3 / 4$ of the length towards the top, apex acute or acuminate, green above, reddish brown tomentose beneath, venation pinnate, lateral veins 14-20 pairs, curved at the margin, prominent on lower surface, tertiary veins scalariform, young leaves densely pubescent above and on nerves beneath. Petiole 0.4-1.2 cm long, fulvous hairy. Male inflorescences in branched spikes, 10-18 $\mathrm{cm}$ long. Flowers with aromatic smell, nearly rounded. Perianth of 6 segments, scalelike. Stamens 8-14, filament slender. Female inflorescences in spikes, 12-20 cm long. Flowers often solitary on the rhachis, longer than the leaf, bearing abortive stamens. Ovary inferior, 3-locular, styles 3, long, spreading. Cupule enclosed nut totally, 1.6-2.2 $\mathrm{cm}$ diam., covered with spines. Nut 1 per locule, broadly conical, $0.6-1.4 \mathrm{~cm}$ diam., shiny brown, dehiscent when mature.

Distribution - India, Nepal, Bangladesh, Myanmar, China, Indochina, Thailand. In Laos: Phong Sali, Louang Prabang, and Xieng Khouang provinces. In Vietnam: in almost all provinces in the north, mainly in Vinh Phu, Hà Bac, and Lang Son provinces.

Habitat \& Ecology - Primary and secondary forests, but only occurring scattered, not forming clearly dominant stands. Usually mixed with Engelhardtia spp., Ixonanthes cochinchinensis, Lithocarpus spp., Madhuca pasquieri, and Quercus spp. Light demanding tree, suitable on sandy soils with medium humidity. Natural regeneration is good, coppice regeneration is possible. Flowering: January to March, October to December; fruiting: January, February, June to August.

Uses - Wood is of good quality, pinkish brown, hard, and resistant to termites and insects. Used for construction and making furniture. The bark is rich in tannin and the fruits are edible.

Specimens examined: D'Alleizette s.n. (L); Balansa 2388 (L); Blauche 4382 (P); Bon 5048 (P); Brune 3865 (P); Chevalier 1669, 1732, 35719 (P); Cuong 363 (L); Dussau 79 (P); Eberhardt s.n. (L); Fleury 30100 (P); Hiep 4229 (L); Pételot 4740, 4741 (P); Poilane 1913, 2194, 2394, 2425, 2621, 4805, 5311, 10554, 10687, 10815, 11071, 12127, 12153, 12197, 12641, 13427, 16244, 17954, 18880, $19027,20008,20124,22829,22831,24203,24727,24840,24876,24888,24912,24914,25075,27154$, 30063 (P), 13027, 20298, 20504 (L), 19926, 24283, 24875, 27124 (L, P); Soejarto 10395, 11034 (L); Toan 32 (L); Tsang 27132, 27408, 27459, 30733, 30754 (P); Vidal 5697, 16966, 74413 (P).

\section{IRVINGIACEAE}

Evergreen trees with conspicuous annular leaf scars on young branches. Stipules swordlike, enclosing the terminal buds, caducous. Petiole grooved above. Leaves simple, coriaceous or subcoriaceous, glabrous or pubescent, margin entire. Inflorescences axillary or terminal panicles. Bracts small, early caducous. Flowers 5-merous, bisexual. 
Sepals connate at base, imbricate in bud. Petals exceeding sepals, imbricate in bud. Stamens 10, inserted beneath the disc. Ovary superior, 2-locular, conical or somewhat flattened, sessile on the torus-like disc, stigma inconspicuous, ovules solitary. Fruit a large 1-seeded drupe.

Distribution - Worldwide: 1 genus, 8 species. In Laos and Vietnam: 1 species. Often included under Simaroubaceae.

\section{IRVINGIA Hook.f.}

Irvingia malayana Oliv. ex A. Benn. - Fig. 25

Synonyms - Irvingia harmandiana Pierre ex Laness.; I. oliveri Pierre

Vernacular names - Mai bok, Bok (L); Konia (V).

Evergreen trees up to $35 \mathrm{~m}$ high with dense spreading crown and massive, buttressed trunk at base, up to $200 \mathrm{~cm}$ diameter. Bark pale grey-brown, smooth becoming irregularly cracked and flaky when old, inner bark pale orange. Branchlets with conspicuous

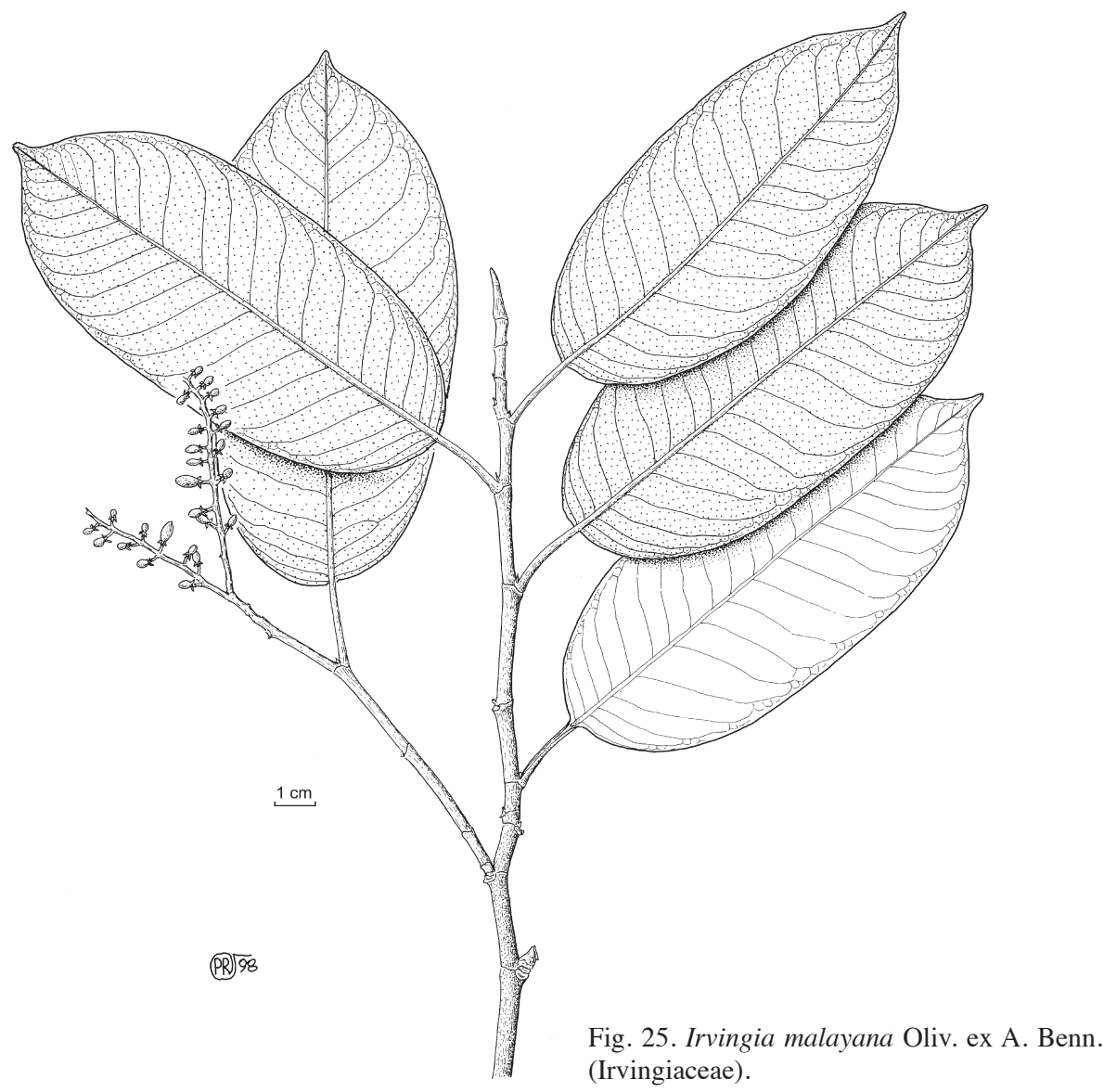


annular leaf-scars. Stipules sword-like, $1.5-3 \mathrm{~cm}$ long, enclosing the terminal buds, early caducous. Petiole $1-2 \mathrm{~cm}$ long, glabrous, grooved above. Leaves elliptic, ovate, $7-20$ by $2.5-9 \mathrm{~cm}$, base acute, obtuse, slightly oblique, margin entire, apex acute, mature leaves completely glabrous, dark green and shiny above, usually pale grey-green and glabrescent below, secondary veins $8-10$ pairs, venation reticulate, conspicuous on both surfaces. Inflorescences axillary, or terminal panicles or raceme. Bracts ovate with acute apex. Flowers small, $6 \mathrm{~mm}$ long, greenish white or yellowish. Petals free, about 3 times as long as sepals. Stamens 10, free, attached outside and below the central disc. Ovary superior, 2-locular, style 1, stigma inconspicuous. Fruit ovoid or ellipsoid, 6 by $4 \mathrm{~cm}$, fleshy, green when young and yellow when mature, pendulous on long stalk. Seed 1 with white, fatty cotyledons.

Distribution - India, Myanmar, Indochina, Peninsular Malaysia, Indonesia (Sumatra, Borneo). In Laos: All tropical parts of the country. In Vietnam: Quang Nam-Dà Nang and Lâm Dông provinces.

Habitat \& Ecology - Light-demanding tree when young, frequent in dry deciduous Dipterocarp forest, dry evergreen forest, tropical rain forest, altitude below $300 \mathrm{~m}$. In Laos: flowering: January to March; fruiting: February to April. In Vietnam: flowering: May, June; fruiting: September to November.

Uses - Used for general construction, excellent as charcoal. Ripe fruits sweet and edible. Seeds contain white or yellow oil, used for soap making and lighting, and are edible either cooked or raw.

Note - The genus Irvingia is treated as a member of Simaroubaceae in Nooteboom, Flora of Malesiana, Series 1, Vol. 6 (1962) 193.

Specimens examined: Bon 3288 (P); Evrard 2302 (P); Harmand 653 (P); Hiep 666 (P); Nooteboom $71286(\mathrm{~L})$.

\section{LAURACEAE}

Trees or shrubs, rarely parasitic leafless climbers (Cassytha); trees usually without buttresses. Bark usually smooth, rarely fissured or scaly, often covered with large lenticels, inner bark usually thick, granular, mottled or laminated, often with strong aromatic smell, yellow, orange-brown, pinkish or reddish. Terminal bud naked or covered with bud scales, sometimes resembling small leaves (Actinodaphne). Stipules absent. Leaves simple, spirally arranged, alternate, rarely opposite, subopposite or whorled, often glaucous below, usually with numerous minute oil dots, often aromatic when crushed, secondary veins pinnate, sometimes tripliveined (Cinnamomum). Inflorescences in racemes or panicles or in clusters arising from the trunk or branches, terminal or axillary. Flowers small, regular, greenish white or yellow, fragrant or with rancid smell, bisexual or unisexual, perianth with 3 or 6 lobes in 2 whorls. Stamens $9-12$ alternate, usually attached to the throat of the tube, usually 3 whorls, rarely more (Cinnadenia), anthers 2- or 4-celled, cells opening by valves, usually from base to apex, outer two whorls of anthers as a rule introrse, 3rd whorl extrorse, in Litsea all whorls extrorse, ovary superior. Fruit small to large, berry or drupe, usually with persistent perianth at base, except Litsea. Seed 1 with thin testa, cotyledons large, flat.

Distribution - Throughout the world: c. 35 genera, 2500 species. In Laos and Vietnam: c. 19 genera, 245 species. 
CINNAMOMUM Schaeff.

\section{KEY TO THE SPECIES}

1a. Bark smooth or lenticellate. Leaves opposite or subopposite, tripliveined at base

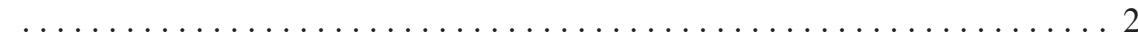

b. Bark fissured. Leaves alternate, venation pinnate ............... 3

2a. Twigs quadrangular, dark green. Leaves leathery, very fragrant when crushed ...

1. C. aromaticum

b. Twigs terete, pale green. Leaves papery, only slightly fragrant when crushed . . . 4. C. iners

3a. Leaves tripliveined, lateral veins 2 or 3 pairs, domatia present in the axils of secondary veins and midrib. Petiole $2-5 \mathrm{~cm}$ long. Perianth cup $0.4-0.6 \mathrm{~cm}$ high ...

2. C. camphora

b. Leaves with 4 or 5 pairs of lateral veins, domatia absent. Petiole $2-3 \mathrm{~cm}$ long. Perianth cup 1-1.6 cm high

3. C. glaucescens

\section{Cinnamomum aromaticum Nees in Wall.}

Synonym - Cinnamomum cassia Blume

Vernacular names - Sa chuang, Say chuang (L); Quế(V).

Medium trees up to $20 \mathrm{~m}$ high, up to $70 \mathrm{~cm}$ diameter. Trunk straight, cylindrical. Bark greyish brown, smooth or lenticellate. All parts of the tree with aromatic smell. Young twigs quadrangular, green, densely blackish brown tomentose, indumenta not persistent. Petioles $1.2-2.5 \mathrm{~cm}$ long. Leaves subopposite, elliptic, 10-24 by $4-7 \mathrm{~cm}$, leathery, shining green, very fragrant when crushed, base cuneate, apex blunt or pointed, tripliveined, veins raised beneath. Inflorescences in terminal and axillary panicles, up to $16 \mathrm{~cm}$ long, hairy. Flowers white, perianth densely silky hairy, lobes 6, in 2 whorls. Stamens 9, in 3 whorls. Ovary ovoid, glabrous, style glabrous. Fruit 1-1.3 by 0.7-0.9 $\mathrm{cm}$, seated on the lobed perianth cup, cup $0.5-0.8 \mathrm{~cm}$ high.

Distribution - India, China, Taiwan, Indochina, Indonesia. In Laos: Xieng Khouang and Vientiane provinces. In Vietnam: Quang Ninh, Yên Bai, Lào Cai, Thanh Hoa, Nghê An, and Quang Nam provinces. Nowadays this species is widely cultivated in many provinces, such as Son La, Lang Son, Hà Tây, Vinh Phu, Hoa Binh, Hà Tinh, and Khanh Hoa.

Habitat \& Ecology - Naturally distributed in primary and secondary forest, altitude below $800 \mathrm{~m}$. Light-demanding tree, slightly shape-tolerant when young, preferring deep and acid soil. Flowering: May to August; fruiting: October to December.

Uses - Wood used for making furniture, sawing boards, implements. Essential oil, extracted from all parts of the tree, used in industry and medicine, for digestive complaints such as flatulence, colic, dyspepsia, diarrhoea, and nausea. It can also be used for colds, influenza, fevers, diabetes, athlete's foot, arthritis, and rheumatism.

Specimens examined: Chevalier 35977 (P), 37713 (L, P), 37782, 38575, 38782 (P); Fean 37717 (P); Fleury $37918(\mathrm{~L}, \mathrm{P})$; Forestier 35976, 38555 (P); Hiep et al. 1329 (P); Pételot $6942(\mathrm{P})$; Poilane 3557, 7055 (P), 31713, 31761 (L, P), 31722, 32367 (P); Quesnel 37711 (P). 


\section{Cinnamomum camphora (L.) T. Nees \& C.H. Eberm.}

Synonym - Laurus camphora L.

Vernacular names - Chuang (L); Long nảo, Re (V).

Trees up to $30 \mathrm{~m}$ high, up to $80 \mathrm{~cm}$ or more diameter. Trunk usually short, stout. Bark greyish brown, deeply fissured, inner bark with aromatic smell. Twigs shining, green. Buds ovoid, pubescent. Leaves alternate, broadly ovate to elliptic, 4-9 by $2.5-5 \mathrm{~cm}$, base oblique or obtuse, apex acuminate, glabrous above, glaucous beneath, 3 main veins, 2 or 3 pairs of lateral veins, raised beneath, with small domatia, fresh leaves aromatic when crushed. Petioles $2-5 \mathrm{~cm}$ long. Inflorescences in terminal and axillary panicles, up to $8 \mathrm{~cm}$ long, whitish hairy. Flowers white. Perianth densely silky hairy, lobes 6. Stamens 9, in 3 whorls, 1st and 2nd whorl of stamens eglandular, 3rd whorl with 2 ovate subsessile glands at the base; staminodes 3. Ovary ovoid, glabrous, style glabrous. Fruit globose, $0.6-1$ by $0.5-0.7 \mathrm{~cm}$, green when young and blackish violet when mature, seated on a lobed $0.4-0.6 \mathrm{~cm}$ high perianth cup.

Distribution - Originated in China. Planted in India, Indochina, Thailand, Malaysia, Indonesia. In Laos and Vietnam: planted in almost all provinces.

Habitat \& Ecology - Naturally in primary and secondary forest, altitude below $1500 \mathrm{~m}$. Light demanding tree, slightly shade tolerant when young, preferring deep, moist and humus rich soil. Tolerates cold well, but poorly resistant to frost. Flowering: February to April; fruiting: September to December.

Uses - Timber greyish or pinkish grey, relatively hard and heavy, resistant to insects and termites, aromatic. Used for construction and making furniture. Essential oil, extracted from all parts of the tree, used in industry and medicine, to treat parasitic infections, diarrhoea, inflammation, itchiness, nervous-related ailments, chest and muscle pains, and toothaches. This species is very successfully planted along the roads and parks of many provinces in Vietnam.

Specimens examined: Bon 1826, 5688 (P); Chevalier 7, 29753, 29762, 29763, 29955, 36594 (P); Dufort $18(\mathrm{P})$; Forestier s.n. (P); Pierre 5160 (P).

\section{Cinnamomum glaucescens (Nees) Hand.-Mazz.}

Synonym - Cinnamomum balansae Lecomte

Vernacular names - Chuang (L); Vù hương, Gù hương (V).

Trees up to $45 \mathrm{~m}$ high, up to $80 \mathrm{~cm}$ or more diameter. Trunk straight. Branchlets glabrous, turning pale black. Bud densely scaled. Bark brown, longitudinally fissured, inner bark with aromatic smell, 1-2 cm thick. Leaves alternate, broad ovate to elliptic, subcoriaceous, $5-14$ by $3-6 \mathrm{~cm}$, base obtuse or acuminate, glabrous, apex acuminate, venation pinnate, 4 or 5 pairs of veins, raised beneath, midrib and secondary veins tomentose above. Petioles 1-3 cm long. Inflorescences in axillary panicles, up to $10 \mathrm{~cm}$ long, hairy. Flowers bisexual, white. Perianth, lobes 6, hairy outside. Stamens 9, in 3 whorls; staminodes 3, triangular. Ovary ovoid, glabrous, style short, stigma disciform. Fruit globose, $0.8-1.5$ by $0.6-1 \mathrm{~cm}$, seated on a lobed perianth cup, cup 1-1.6 $\mathrm{cm}$ high.

Distribution - China, Vietnam, Laos, Thailand. In Laos: Attopeu province. In Vietnam: Vinh Phu, Hoa Binh, Ninh Binh, Thanh Hoa, Nghê An, Quang Tri, Dông Nai, and Binh Dinh provinces. 
Habitat \& Ecology — Primary forest, altitude below $700 \mathrm{~m}$. Light-demanding tree, slightly shade tolerant when young, preferring deep, moist and well-drained soil. Usually mixed with Dracontomelum dao, Parashorea chinensis, and Pometia pinnata. Natural regeneration is very poor. Flowering: February to April; fruiting: September to November.

Uses - Wood heavy, resistant to insects and termites, aromatic, easy to work. Used for construction, making high quality furniture, and sawing boards. Essential oil, extracted from all parts of the tree, used in medicine, soap and lubricant producing.

Specimens examined: Fleury 30173, 37993 (L); Hennipman 3626 (L); Poilane 1073, 15939, $18790,18868,19940(\mathrm{P}), 1108,1272,1368,24505(\mathrm{~L}, \mathrm{P}), 19848(\mathrm{~L})$.

\section{Cinnamomum iners Reinw. ex Blume}

Synonyms - Cinnamomum nitidum Hook.; C. paraneuron Miq.

Vernacular names - Chuang, Si khai ton (L); Re hưong, Re xanh (V).

Medium sized trees up to $24 \mathrm{~m}$ high, up to $60 \mathrm{~cm}$ diameter. Bark greyish brown, smooth or lenticellate, inner bark pinkish, with strong fragrant smell. Sapwood whitish. Twigs slender, pale green, slightly pubescent, then glabrescent. Leaves opposite or subopposite, young leaves pink, elliptic, $8-23$ by $3-8 \mathrm{~cm}$, base cuneate, margin entire, apex blunt or pointed, venation tripliveined, lower surface often glaucous, midrib and nerves raised beneath. Petioles 1-1.5 cm long. Inflorescences in terminal and axillary panicles, up to $20 \mathrm{~cm}$ long, hairy. Flowers creamy, with unpleasant smell. Perianth densely silky hairy, lobes 6. Stamens 9, in 3 whorls; staminodes 3, triangular. Ovary ovoid, glabrous, style glabrous. Fruit globose, $1-1.5$ by $0.8-1 \mathrm{~cm}$, seated on a lobed perianth cup, cup small, $0.4-0.6 \mathrm{~cm}$ high, perianth lobes persistent in fruit.

Distribution - India, Myanmar, Indochina, Thailand, Malaysia, Indonesia, Philippines. In Laos: Vientiane province. In Vietnam: Hoa Binh, Quang Ninh, Vinh Phu, Thanh Hoa, Ninh Binh, Dông Nai, Kom Tum, and Sai Gon provinces.

Habitat \& Ecology - Common in primary and secondary forest, often in moist forest, altitude up to $1200 \mathrm{~m}$. Natural regeneration is good under a forest cover of $20-40 \%$. Flowering: February to April; fruiting: July, August.

Uses - Wood used for construction and making furniture. Bark aromatic, often used for incense production, or together with leaves in tea, and also as a substitute for Cinnamon. The oil from the leaves is used for flavouring sweets and confectionery. This species is sometimes planted as a shade tree.

Specimens examined: Chevalier 35933, 35956, 36680, 36681 (P); Cuong 4504 (P); Fleury 29918 (P); Harmand 185 (P); Poilane 7077, 29392 (P); Thorel 185 (P); Tixier s.n. (P); Vidal 4026 (L, P), $5060(\mathrm{~L})$.

\section{LOGANIACEAE}

Trees, shrubs, climbers, or herbs. Hairs simple. Stipules present or absent. Leaves simple, entire, opposite or whorled, connate at the base by a transverse ridge. Leaf blade ovate, base cuneate, apex acuminate, margin entire, secondary veins pinnate, rarely 
tri-pinnate or -palmate. Inflorescences terminal or axillary, solitary or in cymes. Flowers bisexual, 5- to many, rarely 4-merous, actinomorphic. Calyx united or free. Corolla united, twisted in bud. Stamens inserted on the corolla tube or in the throat, anthers attached at the base. Ovary superior, usually with 2 locules, rarely 1 or 4 , placentas axile or parietal, locules with 1 to many ovules, style single, head not swollen. Fruits berries, drupes, or capsules. Seeds usually numerous, often irregular.

Distribution - Worldwide: c. 20 genera, 400 species. In Laos: 4 genera, c. 12 species. In Vietnam: 5 genera, c. 26 species.

FAGRAEA Thunb.

\section{Fagraea fragrans Roxb.}

Synonyms - Fagraea cochinchinensis A. Chev.; F. peregrine Blume

Vernacular names - Man pa (L); Trai nam bộ, Trai (V).

Evergreen trees up to 8-30 $\mathrm{m}$ high, up to $150 \mathrm{~cm}$ diam. with small buttress at the base. Bark yellow-grey or brown, deeply longitudinal fissured, yellowish white sap, twigs greyish brown, terete, glabrous, nodose. Stipules 1-2 mm long. Petiole 0.7-2.5 cm long, slender, terete, without auricles. Leaves elliptic, $7-12$ by $1.5-5 \mathrm{~cm}$, coriaceous, base acute or cuneate, margin entire, apex acute, acuminate or caudate, both surfaces glabrous, midrib slightly raised above, prominently keeled or ridged below, secondary veins 5-16 pairs, barely visible or invisible above, visible below. Inflorescences axillary or terminal corymbs, $4-13 \mathrm{~cm}$ long, 3 to many flowers, peduncle $1.5-7 \mathrm{~cm}$ long. Flowers very fragrant. Pedicels $0.3-2 \mathrm{~cm}$ long. Sepals 5, connate into a bell-shaped tube, 1.7-3 mm long, lobes $0.7-2 \mathrm{~mm}$ long, apex rounded, spreading in fruit. Petals $5,12-20 \mathrm{~mm}$ long, creamy white turning dull-yellow, tube 6-12 mm long, narrowly funnel-shaped, lobes 5.5-8 mm long. Stamens 5, filaments $1.4-2.2 \mathrm{~cm}$ long, anthers elliptic, 1.5-2 mm long. Ovary glabrous, style longer than the stamens, 17-24 $\mathrm{mm}$ long, stigma $0.7-1 \mathrm{~mm}$ long, capitate or obconical, occasionally faintly bilobed. Fruit globose or subglobose, drupe, 4.5-10 mm diam., green turning orange or red, tip rounded or pointed. Seeds roughly angular, 0.5-2 $\mathrm{mm}$ long.

Distribution - India, Myanmar, Indochina, Thailand, Andaman Island, Malesia. In Laos: Savannakhet (Ban That), Vientiane Municipality, and Vientiane (pers. obs.) provinces. In Vietnam: Hà Bac, Quang Binh, Quang Tri, Quang Nam-Dà Nang, Dac Lac, Dông Nai, Lâm Dông, Kiên Giang, and Tây Ninh provinces.

Habitat \& Ecology - Evergreen forest, mixed deciduous forest, on sandy soil, along roadsides, streams, or rivers, along paddy fields, altitude below $800 \mathrm{~m}$. Often planted as an ornamental or for timber. Flowering: April to July; fruiting: July to November.

Uses - Timber used for house pillars, in construction, and furniture-making. Heartwood used as fuel. Decoctions of the bark are used as a febrifuge and decoctions from the leaves in the treatment of severe diarrhoea. Trees planted for shading.

Specimens examined: D’Alleizette 4904, 6909 (L); Pierre 1832 (L, P), 3697, 3698, 3699 (L); Poilane 16384 (L, P), 18549 (P); Vidal 1752 (P). 


\section{LYTHRACEAE}

Trees, shrubs, or herbs. Stipules absent. Leaves opposite or whorled, simple, margin entire. Inflorescences terminal or axillary panicles. Flowers bisexual, regular. Calyx bell- or funnel-shaped, smooth or ridged, with 3-6 lobes. Petals free, 2-9, or absent, inserted near the mouth of the calyx tube. Stamens twice as many as petals or numerous, inserted on the calyx tube. Ovary with 1-6 chambers, half inferior, ovules numerous, style 1, stigma a small head. Fruits small or large capsules, seated on or surrounded by the persistent calyx. Seeds numerous.

Distribution - Throughout the world except the coldest parts: 25 genera, 600 species. In Laos: 1 genus, c. 10 species. In Vietnam: 5 genera, 23 species.

\section{LAGERSTROEMIA L.}

\section{Lagerstroemia calyculata Kurz}

Synonym - Lagerstroemia angustifolia Pierre ex Laness.

Vernacular names - Peuay dok khao, Peuay peuak na (L); Bằng lăng, Sang lẻ (V).

Large deciduous trees $20-35 \mathrm{~m}$ high, $40-80 \mathrm{~cm}$ diameter. Bark pale creamy-grey, smooth, flaking in thin, rounded plates, inner bark yellowish, fibrous, 6-10 mm thick. Twigs slender, yellow, stellately hairy. Stipules absent. Leaves ovate or elliptic, 7-18 by $2-5 \mathrm{~cm}$, base obtuse, unequal, apex acute, dark brown above and pale yellow beneath when dry, young leaves and twigs densely covered with yellowish star-shaped hairs which easily rub of, lateral veins $10-13$ pairs, larger tertiary veins scalariform, smaller venation reticulate. Petioles $3-5 \mathrm{~mm}$ long, tomentose. Inflorescences in terminal panicles, densely yellow-tomentose, $12-20 \mathrm{~cm}$ long. Bracts and bracteoles early caducous. Flowers white, in groups of 6-8. Calyx bell-shaped, covered with many stellate hairs, tube $5 \mathrm{~mm}$ long, with 6 teeth, densely yellow-hairy outside and inside of teeth apex, without grooves or ridges, Petals 6 , orbiculate. Stamens numerous, subequal, anther orbiculate. Ovary 5- or 6-locular, style simple or divided. Fruit a capsule, ovoid, 6-12 $\mathrm{mm}$ long, dark brown and glossy, dehiscent into 6 pieces, calyx persistent. Seeds c. 8 mm long.

Distribution - Indochina and Thailand. In Laos: Xieng Khouang, Savannakhet, Saravane, and Attopeu provinces. In Vietnam: Son La, Thanh Hoa, Nghê An, Binh Thuân, Tây Ninh, and Dông Nai provinces.

Habitat \& Ecology - Deciduous forests, usually associated with Anisoptera spp., Shorea spp., Terminalia spp., or in Bamboo thickets. Natural and coppice-regeneration are good, although the trees are rather slow growing. Flowering: May to July; fruiting: August to April.

Uses - Sapwood and heartwood distinctive, sapwood white, heartwood greyish yellow or brown, wood hard and heavy. Used for timber, interior furniture-making, wood-boards.

Specimens examined: Kerr 71286 (L); Maxwell 89-775 (L); Poilane 3368, 6633, 10798, 15438, $16258,21523(\mathrm{P})$ 


\section{MAGNOLIACEAE}

Trees or shrubs, trees usually with buttresses. Bark usually smooth, rarely fissured or scaly, inner bark usually thick, with a very spicy smell. Leaves simple, alternate, spirally arranged, commonly with very conspicuous reticulations on both surfaces. Stipules large, enclosing the young bud, soon falling and leaving ring-like scars on the twigs. Flowers solitary, bisexual, large, terminal or sometimes axillary. Tepals mostly 9 or more, free, imbricate, variously coloured. Stamens numerous, free, spirally arranged, filament short, anthers linear, 2-locular. Carpels numerous, free, spirally arranged on an elongated axis, ovules 2 or more in each carpel, ovaries superior. Fruit apocarpous, sometimes syncarpous, fruiting carpels mostly dry and dehiscent, rarely fleshy or indehiscent, each with 1 or more seeds, with red or creamy white fleshy aril, embryo small.

Distribution - Throughout the temperate and tropical regions: c. 12 genera, 200 species. In Laos and Vietnam: c. 7 genera, 39 species.

\section{MICHELIA L.}

\section{KEY TO THE SPECIES}

1a. Inner bark greyish yellow, with aromatic smell. Twigs pale black. Leaves glossy above, silvery ferruginous villose beneath. Petiole slightly swollen at base. Fruit with many follicles, $1-5$ seeds in each follicle . . . . . . . 1. M. balansae

b. Inner bark cream, bad smelling. Twigs pale green. Leaves dull above, pale green beneath. Petiole not swollen at base. Fruit with 3-7 separated follicles, 3-5 seeds in each follicle . . . . . . . . . . . . . . . . . . . . . M. mediocris

\section{Michelia balansae Dandy}

Synonym - Michelia baviensis Finet \& Gagnep.

Vernacular names - Giồi, Giồi bà, Giồi lông (V).

Trees up to $20 \mathrm{~m}$ high, up to $60 \mathrm{~cm}$ diameter. Trunk straight. Bark greyish brown, glabrous, inner bark greyish yellow, with aromatic smell. Twigs pale black, ferruginous tomentose, later glabrous, lenticels sparse, white. Leaves simple, alternate, obovate, $10-20$ by $4-10 \mathrm{~cm}$, coriaceous, base cuneate, apex with a short point, glabrous, glossy above, silvery ferruginous villose beneath, venation pinnate, lateral veins $10-15$ pairs, obvious, tomentose when young. Petioles $1.5-3 \mathrm{~cm}$ long, slightly swollen at base, tomentose. Flower bud enclosed by 3 caducous bracts. Flowers axillary, aromatic. Pedicels 3-3.5 cm long, ferruginous tomentose. Tepals 9, in 3 whorls, white. Stamens and carpels numerous, free, spirally arranged on a tomentose, cylindrical receptacle. Fruit compound, formed by many separate follicles, follicles narrow ovate, 30-45 by $15-18 \mathrm{~mm}$, dehiscing by 2 valves when ripe, 1-5 seeds in each follicle. Seeds red when mature.

Distribution - China and Vietnam. In Vietnam found in almost all provinces of North and Central Vietnam. In Laos: not yet recorded, but most probably present. 
Habitat \& Ecology — Primary and secondary tropical and subtropical forests, altitude below $1000 \mathrm{~m}$. Slow-growing tree, shade tolerant, prefers humid, deep, and fertile soil. Usually mixed with Canarium album, Cinnamomum spp., Lithocarpus spp., Machilus spp., and other Michelia species. Natural regeneration is good under thin forest covered. Flowering: April, May; fruiting: September, October.

Uses - Sapwood and heartwood are distinctive. Sapwood is brownish yellow, heartwood is brown. The timber is very hard, texture fine, aromatic, grain fine, resistant to termites and insects. Used for construction, making furniture and art articles. Seeds used as spices.

Specimens examined: Balansa 3886 (P); Brillet s.n. (P); Chevalier 40966, 41042 (P); Domat 38191 (P); Eberhardt 4460 (P); Fleury 30103 (P); Forestier 40937 (P); Pételot 3548, 5661, 6713, 8648 (P); Poilane 1534, 18893, 27556 (P); Tsang $26866(\mathrm{P})$.

\section{Michelia mediocris Dandy}

Synonyms - Magnolia mediocris (Dandy) Figlar; Michelia tonkinensis A. Chev.

Vernacular names - Giổi, Giồi xanh, Giồi tanh (V).

Trees up to $30 \mathrm{~m}$ high, up to $1 \mathrm{~m}$ diameter. Trunk straight, cylindrical. Bark greyish brown, glabrous, inner bark cream, with bad smell. Sapwood whitish. Twigs pale green. Leaves alternate, elliptic, $6-20$ by $3-8 \mathrm{~cm}$, coriaceous, base rounded or cuneate, apex with a short point or acuminate, both surfaces glabrous, green above, pale green beneath, venation pinnate, lateral veins 7-15 pairs, conspicuous. Petioles 1-2 cm long. Flower buds enclosed by 3 caducous bracts. Flowers terminal, axillary or opposite leaves. Pedicel 3-12 mm long, tomentose. Tepals 9 or 10, white. Stamens and carpels numerous, free, spirally arranged on a tomentose, cylindrical receptacle. Fruit compound, 3-7 separated follicles, $10 \mathrm{~cm}$ long when mature, 3-5 seeds in each follicle, follicles oblong ovate, $12-20$ by $10-13 \mathrm{~mm}$, lenticels many, dehiscing when ripe. Seeds red when mature.

Distribution - China, Vietnam, Cambodia. In Vietnam: in almost all provinces of North and Central Vietnam, mainly in Lào Cai, Hoa Binh, Thanh Hoa, Nghê An, Hà Tinh, Kom Tum, and Gia Lai. In Laos: not yet recorded, but most probably present.

Habitat \& Ecology - Primary and secondary tropical and subtropical forests, altitude up to $1000 \mathrm{~m}$. Light demanding and rather fast-growing tree. Usually mixed with Aglaia gigantea, Canarium album, Cinnamomum spp., Engelhardtia chrysolepis, Lithocarpus spp., Machilus spp., Madhuca pasquierii, and other Michelia species. Natural regeneration is good under thin forest cover. There are two seasons. Main flowering: February, March; fruiting: September, October; minor flowering: July, August; fruiting: March, April.

Uses - Wood with distinct sapwood and heartwood. Sapwood is yellowish beige, heartwood is brownish yellow. Timber very hard, texture fine, easy to work, used for construction, boats, and making furniture. Seeds used as spices and as medicine to treat fever and stomachache.

Specimens examined: Balansa 3195 (P); Hsien 1078 (P); Poilane 297, 6497, 6531, 18054, 18181 , 18229, 22018, 23172 (P). 


\section{MELIACEAE}

Trees or shrubs, rarely with latex or sap. Bark smooth, cracked, fissured, scaly, or flaky, inner bark pinkish, white, or yellowish. Stipules absent. Leaves spirally arranged, alternate, rarely opposite, mostly compound, pinnate, sometimes bi- or tripinnate, rarely simple, leaflets usually opposite or subopposite. Inflorescences panicles, racemes, or spikes, sometimes reduced to fascicles or flowers solitary, axillary. Flowers bisexual or unisexual. Calyx cup-shaped with 3-5 lobes. Petals 3-7, free, narrow and curved backwards, green, white, pink, cream, or yellow. Stamens usually partly or completely united into tube or globose, 3-10 in 1 or rarely 2 whorls. Disc around ovary. Ovary superior, 1-6-locular, with 1 to many ovules per locule. Fruit a capsule, berry, or drupe. Seed winged and then attached to a woody columella, or covered by a sarcotesta or an aril, or without both, usually without endosperm.

Distribution - Throughout the tropical and subtropical regions of the world: c. 51 genera, 575 species. In Laos and Vietnam: c. 15 genera, c. 55 species.

\section{KEY TO THE GENERA}

1a. Slash of the bark without white latex. Stellate hairs or peltate scales absent. Stamens

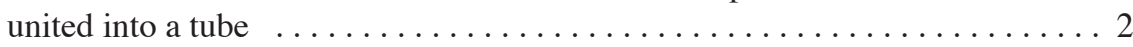

b. Slash of the bark with white latex. Stellate hairs and/or peltate scales present. Stamens united into a globose head ........... 1.Aglaia (spectabilis)

2a. Leaves with pseudogemmula (bud at the end of the leaf). Fruit with 3 or 4 seeds, covered with an orange or red aril ............ 2. Chisocheton

b. Leaves without pseudogemmula. Fruit with many winged seeds . . 3. Chukrasia

\section{AGLAIA Lour.}

Aglaia spectabilis (Miq.) S.S. Jain \& Bennet - Fig. 26

Synonyms - Aglaia gigantea Pellegr.; Amoora gigantea Pierre; A. spectabilis Miq.

Vernacular names - Nook kok (L); Gội nếp, Gội (V).

Large trees up to $40 \mathrm{~m}$ high, $150 \mathrm{~cm}$ diameter. Usually with large buttresses. Bark greyish brown, flaking in squarish scales, sometimes with large orange lenticels, inner bark pinkish, reddish orange, or brown, latex white. Twigs covered with reddish brown or brown stellate hairs or scales. Leaves imparipinnate in dense spirals, up to $100 \mathrm{~cm}$ long. Petioles 9-25 cm long, flattened on the adaxial side, petiole, rhachis, and petiolules covered with pale brown or reddish brown scales. Leaflets 5-9 pairs, opposite, ovate, $8-21$ by 3-7 cm, coriaceous, upper surface usually rugulose, lower surface with pale brown or reddish brown stellate hairs or scales, apex acuminate, base rounded, lateral veins 7-16 pairs. Inflorescences panicles, up to $50 \mathrm{~cm}$ long. Calyx usually stellately hairy outside, 3- or 4-lobed. Petals 3, with or without hairs or scales outside. Stamens united, slightly shorter than corolla, with 5-10 (usually 6) anthers. Disc present. Ovary ovoid, 3- or 4-locular, 1 ovule per locule, style absent. Fruit a globose capsule 4-7 by $2-4.5 \mathrm{~cm}$, red or yellow, densely covered with reddish brown or yellowish brown 


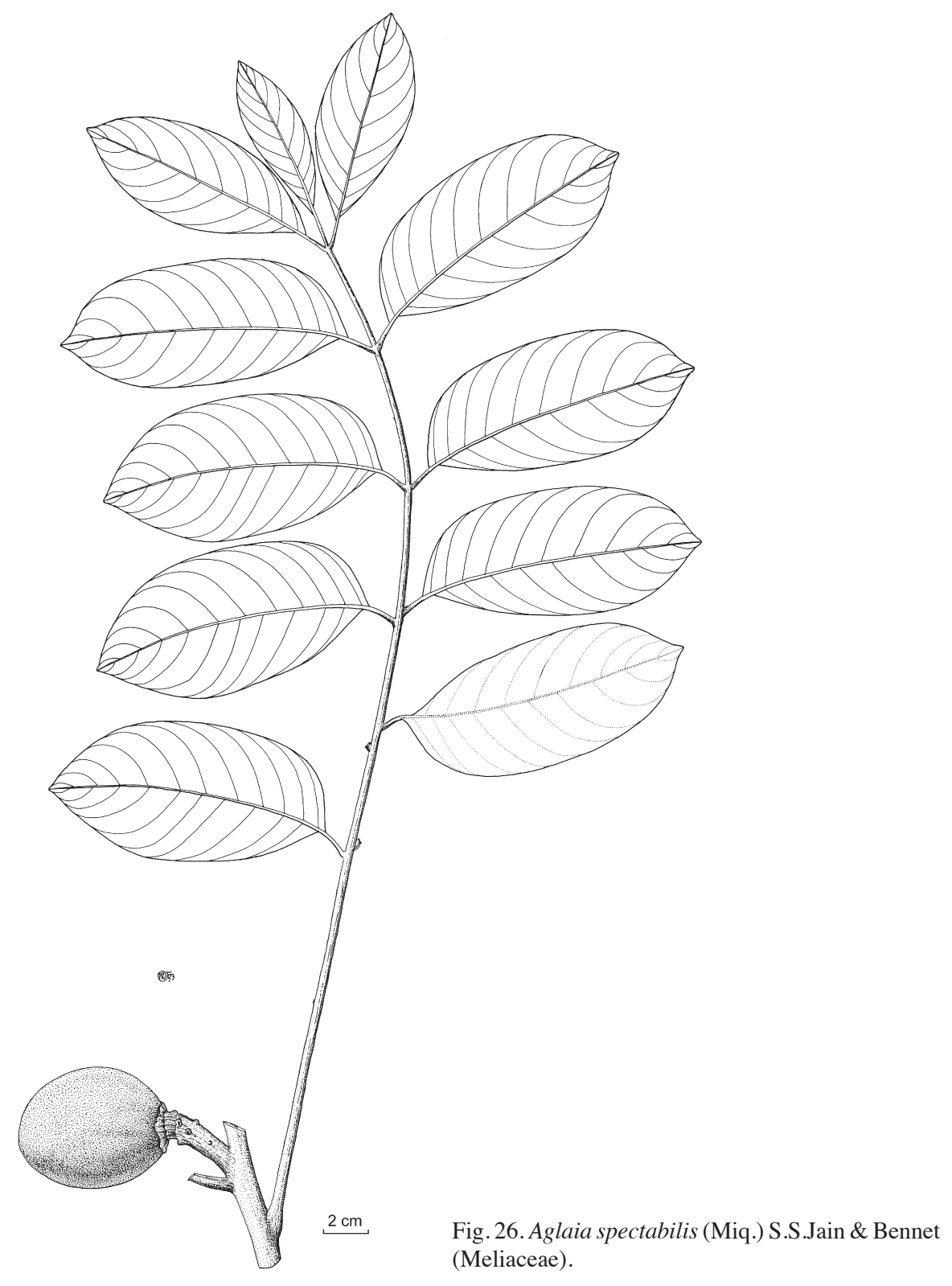

hairs, a little bit splitting open when mature, pericarp usually with white latex. Seeds 3 or 4 , black, covered with an orange-red or red aril.

Distribution - India, Myanmar, China, Indochina, Thailand, Malaysia, Philippines, New Guinea, Australia. In Laos: Sayabouri and Champassak provinces. In Vietnam: in many provinces in the north, mainly in Ninh Binh, Thanh Hoa, and Nghê An provinces. 
Habitat \& Ecology — Primary and secondary forests, altitude below $800 \mathrm{~m}$. Growing on deep, sandy clay, and well-drained soils. Usually mixed with Cryodaphnopsis tonkinensis, Dracotomelon dao, Dysoxylon cochinchinensis, Erythrophloeum fordii, Parashorea chinensis, and Pometia pinnata. Fast-growing tree. Natural regeneration is good. Flowering: April, May; fruiting: September to November.

Uses - Sapwood pinkish, heartwood reddish brown. Used for making furniture, wall panelling, plywood, boxes, suitable for the production of pulp. This species can also be used as ornamental tree.

Specimens examined: Charoenchai 794 (L); Delambre s.n. (P); Fleury 29938, 29940, 30148, 37820 (P); Harmand 545, 882 (P); Maxwell 76-132, 76-175 (L); Pierre 55 (L), 1444 (P); Poilane 6322, $10739(\mathrm{P})$.

\section{CHISOCHETON Blume}

\section{Chisocheton cumingianus (C.DC.) Harms}

Synonyms - Chisocheton balansae C.DC.; C. chinensis Merr.; C. cochinchinensis Pierre; C.paniculatus Hiern; C. siamensis Craib

Vernacular names - Kouang (L); Quyếch, Quyếch tía, Gội nước (V).

Trees up to $25 \mathrm{~m}$ high, $80 \mathrm{~cm}$ diameter. Usually with large buttresses. Bark greyish brown, inner bark chestnut brown, sapwood straw. Twigs covered with blackish brown tomentum. Leaves paripinnate or imparipinnate with pseudogemmula (apical bud) at tip, alternate, up to $100 \mathrm{~cm}$ long, petiole 5-14 cm long. Leaflets 5-10 pairs, opposite or subopposite, ovate to elliptic, $7-25$ by $3-7 \mathrm{~cm}$, papery to coriaceous, base nearly rounded and slightly oblique, margin entire, apex shortly cuspidate, dark green when mature. Petiolules 4-12 mm long. Inflorescences panicles, up to $50 \mathrm{~cm}$ long, axillary. Flowers bisexual. Sepals united, 4-lobed. Petals 4, united at lower part into a cylindrical tube, imbricate, yellow to white. Stamens tube cylindrical, as long as corolla, with 6 anthers. Disc present. Ovary ovoid, 4-locular, 1 ovule per locule, style hairy. Fruit a capsule, globose to pyriform, red or orange-red, $3-6$ by $2.5-6 \mathrm{~cm}$, splitting into $3-5$ sections, but usually 4 , pericarp usually with white latex. Seeds 3 or 4 , black, covered with an orange aril.

Distribution - India, China, South East Asia. In Laos: Sayabouri province. In Vietnam: Yên Bai, Lào Cai, Tuyên Quang, Hà Giang, Vinh Phu, Hoa Binh, Hà Tây, Ninh Binh, Thanh Hoa, Nghê An, Hà Tinh, Minh Hai, and Kiên Giang provinces.

Habitat \& Ecology - Wet and very light conditions in secondary forests. Usually mixed with Aglaia gigantea, Albizia lucida, Caryodaphnopsis tonkinensis, Dalbergia balansae, and Pterocarpus tonkinensis. Fast-growing tree. Natural regeneration is good. Flowering: January, February; fruiting: April, May.

Uses - Wood white and soft. Used for making furniture, wall panelling, plywood, boxes, and is suitable for the production of pulp. This species can also be used as ornamental tree.

Specimens examined - Coode 5454 (L); Pierre 1397 (L); Soejarto et al. 10209, 10254 (L); Sonett 1224 (P); Sulit 5662 (L); Tanalt s.n. (P). 


\section{CHUKRASIA A. Juss.}

\section{Chukrasia tabularis A. Juss.}

Synonyms - Chickrassia tabularis (A. Juss.) Wight \& Arn.; Dysoxylum esquirolli H. Lév.; Swietenia chickrassa Roxb.

Vernacular names - Nhom, Nhom hin, Nhom khao (L); Lát, Lát hoa (V).

Deciduous trees up to $40 \mathrm{~m}$ high, up to $120 \mathrm{~cm}$ diam., buttresses present. Bark dark brown, fissured vertically and scaling or cracking into rectangular blocks, inner bark reddish brown or pinkish. Sapwood straw, heartwood yellow to reddish brown. Twigs grey. Leaves bipinnate with incised or lobed leaflets when young, 30-80 cm long. Petioles 4-9 cm long, swollen at base. Leaflets 7-13 pairs, alternate or subopposite, ovate to elliptic, $6-15$ by $3-6 \mathrm{~cm}$, base oblique, margin entire (when mature), apex tapering, venation pinnate, secondary veins $10-15$ pairs, domatia present, petiolules $2-6 \mathrm{~mm}$ long. Inflorescences panicles, axillary, sometimes terminal. Bracts narrowly triangular, often caducous. Flowers bisexual. Calyx 5-lobed, densely brown hairy. Petals 5, free, slightly curved, spreading, hairy outside, glabrous inside. Stamen tube cylindrical, slight narrower towards top, glabrous, with 10 anthers attached to the margin. Ovary tomentose. Fruit a capsule, ovoid, woody, dark brown, $2-4.5$ by $2-3.5 \mathrm{~cm}$, opening by 3-5 valves from apex. Seeds many, $1-1.3 \mathrm{~cm}$ long, winged.

Distribution - Sri Lanka, India, Nepal, China, Japan, Indochina, Thailand, Malaysia, Indonesia (Borneo). In Laos: Houa Phan (Sam Nua Distr.) and Xieng Khouang provinces. In Vietnam: in many provinces, such as Lang Son, Son La, Lào Cai, Yên Bai, Lai Châu, Tuyên Quang, Binh Ninh, Hoa Binh, Thanh Hoa, Nghê An, Hà Tinh, and Quang Binh.

Habitat \& Ecology - Usually on limestone mountains, altitude below $800 \mathrm{~m}$. Usually mixed with Dracontomelum dao, Garcinia spp., and Peltophorum tonkinensis. Slow growing and light demanding tree, but tolerant to shade when young. Natural regeneration is good. Flowering: June, July; fruiting: November to January.

Uses - Wood hard and heavy, grain fine. Used for construction, high grade cabinet work, decorative panelling, doors, windows, light flooring and making ships, boats, and furniture.

Specimens examined: Brillet 9, 12 (P); Fleury 30143 (P); Harmand 731, 907, 931 (P); Kerr 21292 (L, P); Kostermans 23460 (L); Maxwell 75-388, 91-923, $92-506$ (L); Pierre 877, 6487, s.n. (P); Poilane 11526, 17818 (L); Ridsdale 16 (L).

\section{MIMOSACEAE}

Trees, shrubs or lianas, very rarely herbs (Mimosa, Neptunia); branches unarmed or armed with stipular thorns (rarely axillary thorns) or scattered prickles on the internodes. Stipules rarely absent, usually caducous; in some genera reduced to spines. Leaves alternate, pinnate or bipinnate, often with glands on the rhachis. Leaflets many pairs, some with sleep movements, or touch-sensitive. Flowers regular (actinomorphic), crowded into globose heads or cylindric spikes, rarely racemose, some inflorescences monoecious. Sepal lobes 5, usually valvate. Petals 5, equal, valvate in bud, usually united above the base. Stamens few to numerous, free, joined at the base, or united, 
forming a tube; anthers attached at the back. Ovary solitary or several, free, superior, stigma small, tubular, terminal. Pods dehiscent or indehiscent, straight, curved, or spirally twisted, sometimes breaking into 1-seeded segments. Seeds usually in two rows, ovate or orbicular, often compressed.

Distribution - Mainly in the tropical and subtropical regions of the world: c. 60 genera, c. 3000 species. In Vietnam: 13 genera, 62 species. In Laos: 12 genera, 34 species.

\section{KEY TO THE GENERA}

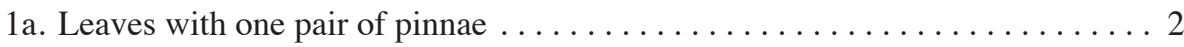

b. Leaves usually with more than one pair of pinnae $\ldots \ldots \ldots \ldots \ldots \ldots \ldots$

2a. Branchlets armed with spinescent stipules. Leaflets 1 pair per pinna, sessile ....

5. Pithecellobium (P. dulce)

b. Branchlets unarmed and without spinescent stipules. Leaflets more than 2 pairs per pinna, petiolulate .................. X. Xylia (X. xylocarpa)

3a. Leaves with extrafloral nectaries on petioles, rhachises, or pinnae. Leaflets opposite. Seeds brown or black when mature $\ldots \ldots \ldots \ldots \ldots \ldots \ldots \ldots \ldots$

b. Leaves without extrafloral nectaries on petioles, rhachises, or pinnae. Leaflets alternate. Seeds red when mature . . . . . . . . . . . . . 1.

4a. Inflorescences pendulous or not, not consisting of clavate head $\ldots \ldots \ldots \ldots 5$

b. Inflorescences consisting of pedunculate pendulous clavate heads $\ldots \ldots \ldots \ldots$

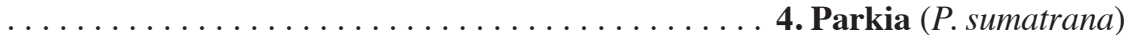

5a. Flowers usually heteromorphic (excepted Albizia procera). Pods brownish or blackish outside when mature. Seeds with pleurogram . . . . . . . . 6

b. Flowers uniform. Pods reddish or orange yellowish outside when mature. Seeds

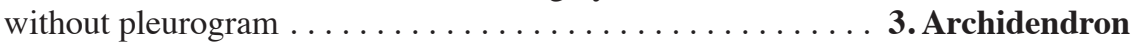

6a. Central flowers with 5 perianth segments. Pods dehiscent ........ 2. Albizia

b. Central flowers with 7 or 8 perianth segments. Pods indehiscent .. 6. Samanea

\section{ADENANTHERA L.}

Adenanthera microsperma Teijsm. \& Binn. - Fig. 27

Synonym - Adenanthera pavonina L. var. microsperma (Teijsm. \& Binn.) I.C. Nielsen

Vernacular names - Lam ta khouay, Lam ta khway $(\mathrm{L})$; Muồng ràng ràng $(\mathrm{V})$.

Deciduous trees up to $30 \mathrm{~m}$ high, up to $90 \mathrm{~cm}$ diameter. Crown broad, rounded and large, branches spreading. Bark dark brown or greyish, flaking, inner bark pale cream. Stipules filiform, less than $0.5 \mathrm{~mm}$ long, puberulous, caducous. Leaves bipinnate, imparipinnate, $12-21 \mathrm{~cm}$ long, without extrafloral nectaries, pinnae opposite, 3-5(-6) pairs. Leaflets 5-9 per pinna, alternate, irregular ovate-elliptic or obovate-elliptic, 1.5-3.5 by $1-2 \mathrm{~cm}$, base cuneate to rounded, apex rounded to truncate, often emarginate or mucronulate, dark grey-green above, pale grey-green below, both surfaces puberulous to glabrous. Inflorescences racemes, incl. peduncle 6-20(-25) cm long. Bracts filiform, $0.75 \mathrm{~mm}$ long, caducous. Pedicels $1.5-3 \mathrm{~mm}$ long, usually puberulous to sericeous (rarely glabrous). Flowers creamy-yellow, turning orange with age. Calyx 5-lobed, 


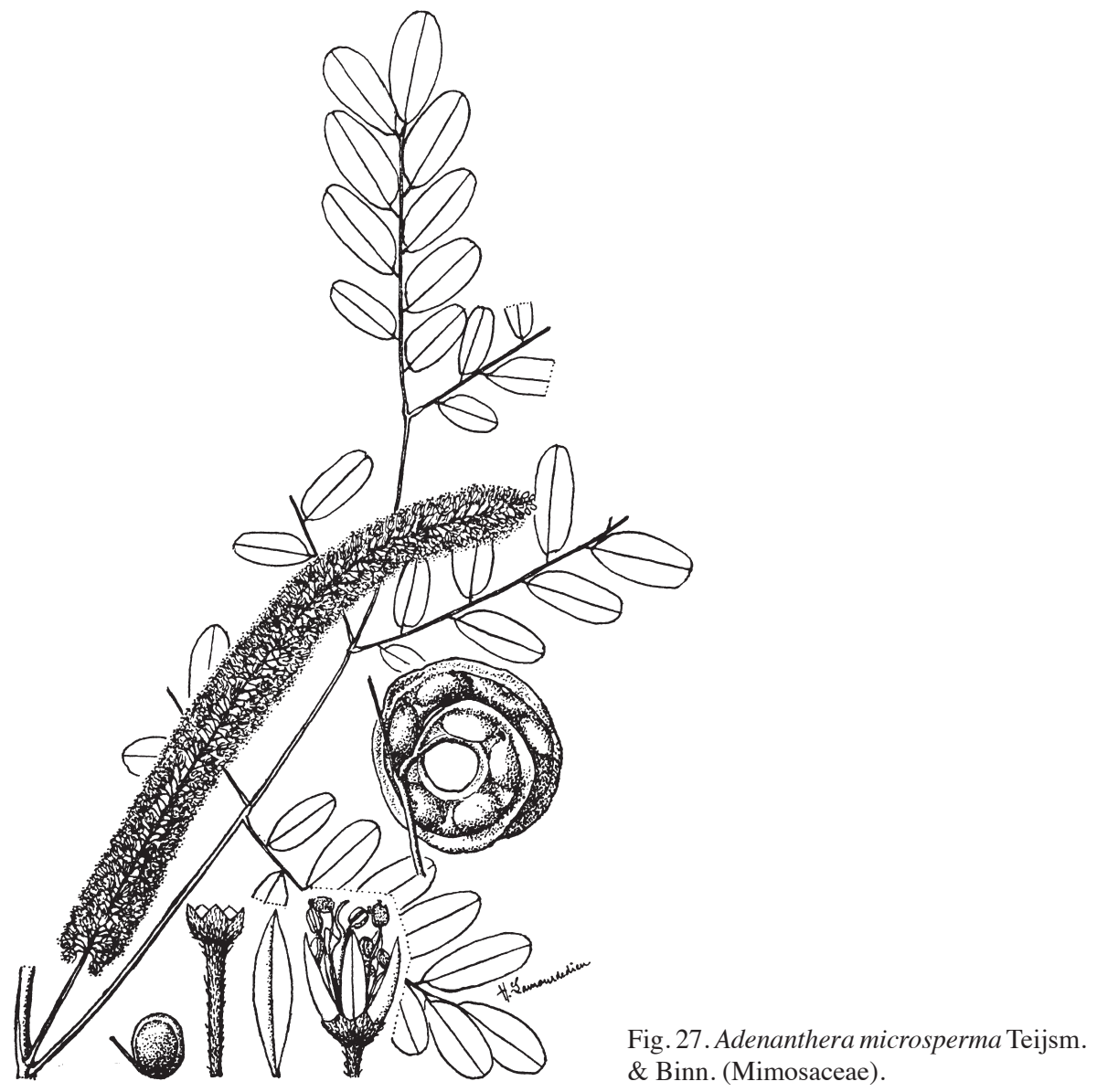

shallowly cup-shaped, $0.5-0.75 \mathrm{~mm}$ long, puberulous to sericeous (rarely glabrous). Petals 5, narrowly ovate or elliptic, $2.5-3.5 \mathrm{~mm}$ long, apex acute, usually glabrous (rarely puberulous towards the apex). Stamens 10, free, 3-4.5 mm long; anthers 0.5 $\mathrm{mm}$ long, glabrous, with a gland at the tip. Ovary 1.6-2.2 mm long, densely sericeous, style 1-1.5 mm long. Pods brown to dark brown, strap-shaped, very thin, twisted in a tight coil, dehiscent, $15-20$ by $0.8-1.2 \mathrm{~cm}$. Seeds orbicular to elliptic, $5-8$ by $4-7$ by $4 \mathrm{~mm}$, bright red, smooth, glossy.

Distribution - Myanmar, South China, Thailand, Indochina, Malesia. In Laos: Louang Prabang, Sayabouri, and Vientiane (Ban That Louang) provinces. In Vietnam: Bac Thai, Kiên Giang, Quang Ninh, Vinh Phu, Quang Nam-Dà Nang, Gia Lai, Kon Tum, Dông Nai, Hô Chi Minh, Hà Nôi, and Minh Hai provinces.

Habitat \& Ecology - Dry evergreen and deciduous forest, forest margins, along streams and rivers, in gaps, altitude up to $600 \mathrm{~m}$. Flowering and fruiting throughout the year.

Uses - Timber used for construction and for making implements. The tree is planted as a decorative and shade providing tree. 
Specimens examined: D'Alleizette 1985 (L); Balansa 5, 1302, 2177, 4726, 4736 (L, P), 4839 (P); Belval 19 (P); Bon 2328, 2589, 4787 (P); Carrick 1602 (L); Chevalier 36759, 37605, 37749, 37881 (P); Clemens 4131 (P); Donmat 38159 (P); Evrard 2303 (P); Fleury 37614 (P); Hiep 2 (P), 539 (L, P); Maxwell 87-348 (L); Pételot 4935 (P); Pierre 730, 1816, 6552 (P); Poilane 42, 8334, 10113, 18152, 21347, 28943 (P), 9820 (L, P), 27132 (L); Service forestier 1 (P); Soejarto 5869 (L); Talmy 271 (P); Tsang 29859 (L, P), 27445, 29119, 29984 (P), 30449 (L); Vidal 829 (P).

\section{ALBIZIA Durazz.}

Shrubs, trees, usually unarmed, or lianas, or lianas armed with recurved hooks from the base of the leaf-scars. Stipules present, subular to linear or auriculate, often early caducous, rarely spinescent. Leaves bipinnate, usually more than one pair of pinnae, not sensitive to the touch, with glandular rhachis and pinnae. Leaflets opposite, sessile or stalked. Inflorescences composed of pedunculate glomerules or corymbs which are either axillary or aggregated into terminal or axillary panicles; floral bracts small, linear-oblong, or absent. Flowers pentamerous, usually dimorphic (uniform for 5 species, incl. Albizia procera), the marginal flowers in each flowerhead bisexual, the central flower male and enlarged with a conspicuous nectary. Sepals connate, 5-toothed, valvate. Petals connate, valvate, 5-lobed (rarely 4). Stamens numerous, filaments united into a tube at the base; anthers eglandular, glabrous. Ovary solitary, sessile or stipitate. Pods chartaceous to coriaceous, straight, sometimes curved, flat, dehiscent; endocarp not separated from exocarp, brownish or blackish outside. Seeds dark brown or black, circular or elliptic, \pm flattened, with a hard testa, wingless, with a pleurogram, aril absent; endosperm absent; cotyledons large, radicle curved.

\section{KEY TO THE SPECIES}

1a. Leaflets up to 6 pairs. Glomerules solitary from leaf-axils. Sepals more than $3 \mathrm{~mm}$

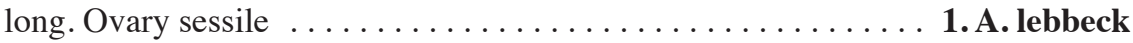

b. Leaflets 7 or more pairs. Glomerules in axillary or terminal panicles. Sepals less

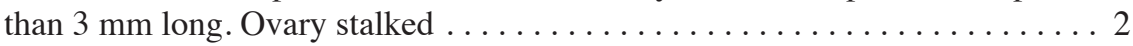

2a. Petiolules up to $1 \mathrm{~mm}$ long. Sepals $1-1.5 \mathrm{~mm}$ long. Petals up to $6.5 \mathrm{~mm}$ long. Ovary up to $1 \mathrm{~mm}$ long, hairy $\ldots \ldots \ldots \ldots \ldots \ldots \ldots \ldots \ldots \ldots \ldots \ldots \ldots$. A. odoratissima

b. Petiolules more than $1 \mathrm{~mm}$ long. Sepals $2.5-3 \mathrm{~mm}$ long. Petals up to $12.5 \mathrm{~mm}$ long. Ovary $0.3-0.5 \mathrm{~mm}$ long, glabrous

3. A. procera

\section{Albizia lebbeck (L.) Benth. - Fig. 28}

Synonyms - Acacia lebbeck (L.) Willd.; Mimosa lebbeck L.

Vernacular names - Khan houng, Ka se (L); Lim vang, Mang lai (V).

Deciduous trees up to $30 \mathrm{~m}$ high, up to $90 \mathrm{~cm}$ diam., bole up to $15 \mathrm{~m}$ tall. Crown spreading, branches large, twisted. Bark dark brown, densely but shallowly cracked. Stipules inconspicuous. Leaves bipinnate, paripinnate, 5-10 $\mathrm{cm}$ long, with a gland c. $1.5 \mathrm{~cm}$ above the base of the petiole and often additional ones at the junction of some of the pinnae; pinnae opposite, 2-4(-5) pairs, up to $9 \mathrm{~cm}$ long. Leaflets opposite, 3-8 pairs per pinna, chartaceous, irregular trapezoid to rhomboid or obovate, $1.5-5.5$ by 
$0.9-3.5 \mathrm{~cm}$, base irregular broadly cuneate to truncate or obliquely cordate, apex rounded to truncate, lower surface tomentose to glabrous, upper surface glabrous to puberulous. Inflorescences consisting of 2 or more pedunculate corymbs in the distal leaf-axils or corymbs arranged in a short raceme at the end of the branches, peduncle $10 \mathrm{~cm}$ long, tomentose to sparsely puberulous, corymbs with 15-40 pedicellate, dimorphic flowers. Marginal flowers pentamerous, pedicel 4(-7) mm long. Calyx greenish yellow, tube-like, funnel-shaped, 3.5-5 mm long, puberulous, teeth narrowly triangular, $0.75-1 \mathrm{~mm}$ long. Corolla 5, greenish yellow, funnelshaped, 7.5-11 mm long, tube glabrous, lobes broadly ovate, 2.5-4 $\mathrm{mm}$ long, puberulous at the apex. Stamens white to yellow at the base, pale green or yellowish green towards the top, staminal tube shorter than the corolla tube, $4-5 \mathrm{~mm}$ long. Ovary sessile, 3-4 mm long, glabrous. Pods pale straw-coloured to brownish, strap-like, gradually narrowing towards both ends, flat, $15-35$ by $3-5 \mathrm{~cm}$, glabrous, dehiscing along both sutures. Seeds flat, elliptic, 10 by $6-7$ by $1-1.5 \mathrm{~mm}$, areole c. 5 by $2 \mathrm{~mm}$, with pleurogram parallel to the margins, open towards hilum.

Distribution - Tropical and subtropical Asia and Africa, but intro-

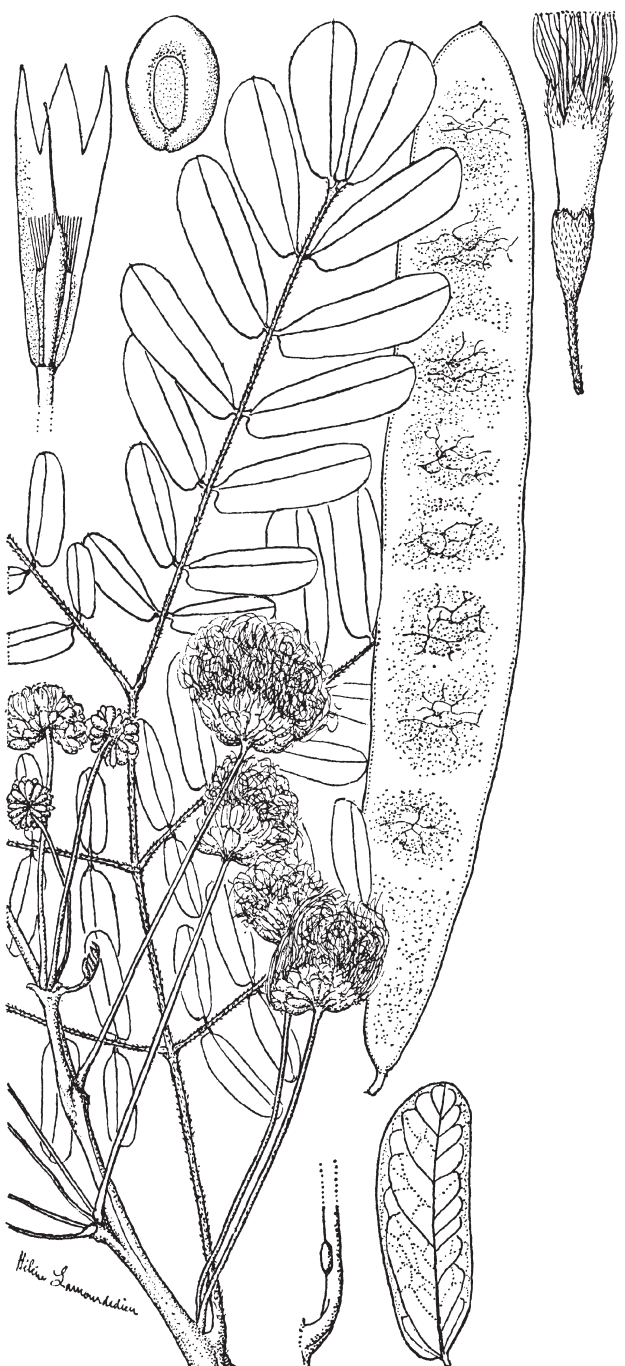

Fig. 28. Albizia lebbeck (L.) Benth. (Mimosaceae). duced and cultivated all over the tropics. In Laos: Louang Prabang and Vientiane provinces. In Vietnam: Hà Bac, Quang Nam-Dà Nang, Gia Lai, Long An, Hà Nôi, Hô Chi Minh, and An Giang provinces.

Habitat \& Ecology - Often common in deciduous forest, mixed evergreen forest, open forest, altitude up to $750 \mathrm{~m}$. Flowering: March to July; fruiting: April to August.

Uses - Used for general construction, furniture, bark pounded used for soap, planted as a shade tree because of the rather short trunk and wide crown.

Specimens examined: D’Alleizette 951 (L); Bon 5668 (P); Chevalier 29562, 39415, 39722 (P); Clemens 3266 (P); Dussaud 66 (P); Evrard 1667 (P); Maxwell 75-347, 96-428, 99-190 (L); Pierre 1860 (P); Poilane 5840, 8397 (L, P), 9638, 39999, 40048 (P); Pételot s.n. (P). 
2. Albizia odoratissima (L.f.) Benth. - Fig. 29

Synonyms - Acacia odoratissima (L.f.) Willd.; Mimosa odoratissima L.f.

Vernacular names - Khang hung, Du salen, Len (Louang Prabang prov.) (L); Xua (Kien Gian), Hop hoàn thơm (V).

Deciduous trees up to $40 \mathrm{~m}$ high, up to $60 \mathrm{~cm}$ diam., branchlets terete. Bark dark grey, slightly cracked, peeling in irregular small flakes, inner bark reddish. Stipules filiform, c. $2.5 \mathrm{~mm}$ long, early caducous. Leaves bipinnate, paripinnate, 7-20 cm long; glands $1-2 \mathrm{~cm}$ above the base of the petiole and between the junctions of the 2 distal pairs of pinnae; lower gland elliptic, cushion-shaped, $2 \mathrm{~mm}$ diam.; upper gland circular, $1 \mathrm{~mm}$

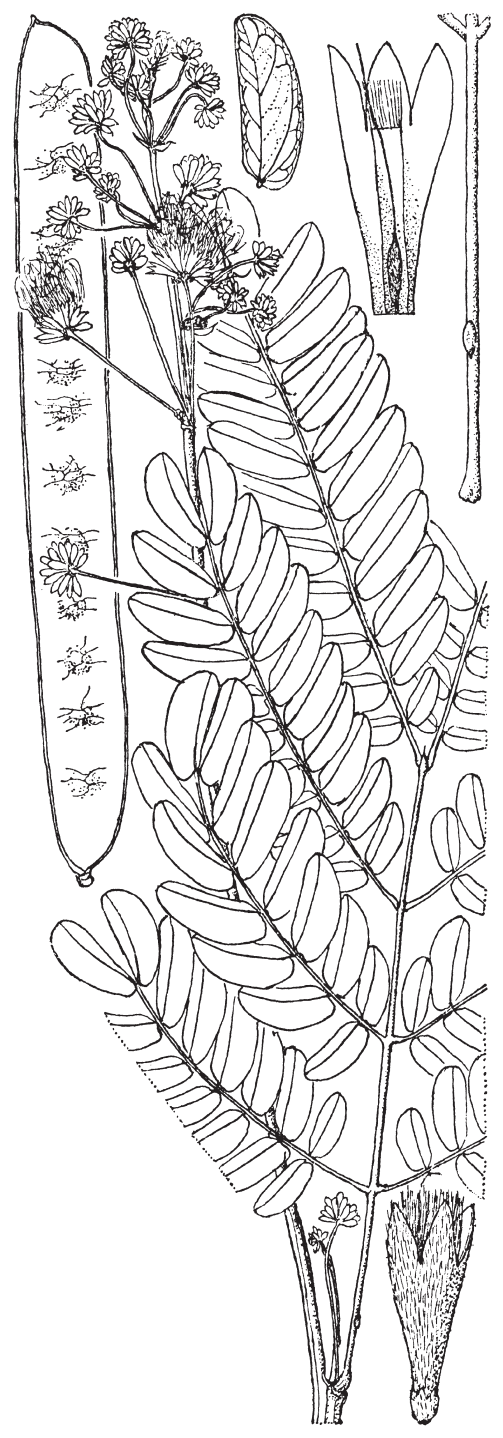
diam.; pinnae opposite, $3-5$ pairs, $7-14 \mathrm{~cm}$ long. Leaflets opposite, $10-16$ pairs per pinna, petiolulate (up to $1 \mathrm{~mm}$ long), chartaceous, broadly elliptic, distal pair obovate, $1.1-3.5$ by $0.6-1.2 \mathrm{~cm}$, base irregular cuneate to truncate, apex obtuse, rounded, often mucronate, both surfaces glabrous to tomentose, main vein removed $1 / 3-1 / 5$ of the width of the leaflet from the upper margin. Inflorescences terminal panicles, $8-20 \mathrm{~cm}$ long, puberulous to tomentose, composed of pedunculate corymbs, $1-2 \mathrm{~cm}$ long, bearing heads of $10-15$, sessile, dimorphic flowers. Calyx tube-like, funnel-shaped, $1-1.5 \mathrm{~mm}$ long, teeth triangular, less than $0.25 \mathrm{~mm}$ long, apex acute, puberulous to tomentose. Corolla funnel-shaped, $4.5-6.5 \mathrm{~mm}$ long, lobes ovate-elliptic, $2-2.5 \mathrm{~mm}$ long, apex acute, puberulous to tomentose. Stamens numerous, longer than the petals, filaments slender, filiform. Ovary puberulous to tomentose, stipe c. $1 \mathrm{~mm}$ long. Pods flat, pale brown, irregularly rectangular, $10-22$ by $2-3.5 \mathrm{~cm}$, glabrous to puberulous, dehiscent. Seeds 8-12, ovate, flat, 9 by 6 by $1.5 \mathrm{~mm}$, areole 5 by $2.5 \mathrm{~mm}$, pleurogram parallel to the margins.

Distribution - India, Myanmar, China, Thailand, Indochina. In Laos: Phong Sali, Luoang Namtha (Muong Sing), Louang Prabang (Pac $\mathrm{Ou}$, Phou Soun, Phou Khouane), and Xieng Khouang (Muong Soui-Muong You) provinces. In Vietnam: Lai Châu, Kiên Giang, Dac Lac, Vinh Phu, Lâm Dông, Dông Nai, and An Giang provinces.

Fig. 29. Albizia odoratissima (L.f.) Benth. (Mimosaceae). 
Habitat \& Ecology - Open areas, dry deciduous forest, secondary forest, in firedamaged forest, in hill mixed evergreen forest, hardwood forest, altitude 400-1500 m. Flowering: March to June; fruiting: May to December.

Uses - Wood used in construction, house-building, especially for high quality exterior joineries, gymnastic instruments, wood carving, and writing materials.

Specimens examined: Averyanov et al. VH 1322 (P); Chevalier 37287, 37696, 38080, 40286 (P); Dussaud 66 (P); Fukuoka T-63707 (L); Maxwell 96-510, 97-396 (L); Pierre 5965 (P); Poilane 3995, 26275 (L, P), 18167 (L), 20126, 20214, 20216, 23479, 26023, 26917 (P); Schmid s.n. (P); Thorel 99478 (P); Vidal 2532, 2605 (P).

\section{Albizia procera (Roxb.) Benth. - Fig. 30}

Synonyms - Acacia procera (Roxb.) Willd.; Mimosa procera Roxb.

Vernacular names - Thon (L); Mù cua, Muồng xanh (V).

Deciduous or semi-deciduous trees up to $30 \mathrm{~m}$ high, up to $60 \mathrm{~cm}$ diam., bole straight or crooked, up to $9 \mathrm{~m}$. Bark greyish, glabrous, inner bark grey-brown. Branchlets terete, glabrous. Stipules filiform, c. $0.5 \mathrm{~mm}$, or early caducous. Leaves bipinnate, paripinnate, $10-30 \mathrm{~cm}$ long, gland $1-1.5 \mathrm{~cm}$ above the base of the petiole, \pm narrowly elliptic, sessile, flat and disc-like or with raised margins and concave, 4-10 mm long; pinnae opposite or subopposite, 2-5 pairs, $12-20 \mathrm{~cm}$ long, glabrous, with elliptic glands, c. $1 \mathrm{~mm}$ diam., below the junctions of the 1-3 distal pairs of petiolules. Petiolule c. $2 \mathrm{~mm}$. Leaflets opposite, 5-11 pairs per pinna, petiolulate ( $>1 \mathrm{~mm}$ long), chartaceous, ovate to elliptic or \pm rhomboid, $2-4.5(-6)$ by $1-2.5(-3.2) \mathrm{cm}$, base irregular cuneate to truncate, apex rounded or subtruncate, often emarginate, mucronate, both surfaces sparsely appressed puberulous, main vein slightly excentric, often diagonal. Inflorescences composed of pedunculate glomerules aggregated into terminal or axillary panicles; peduncles $2-5$ in fascicles, $0.8-3 \mathrm{~cm}$, glomerules with $15-30$ sessile, uniform, bisexual, 5-merous flowers. Calyx light green, tube-like funnel-shaped, glabrous, 2.5-3 mm long, teeth triangular, 0.75-1.2 $\mathrm{mm}$ long, apex acute. Corolla greenish white, tube-like funnel-shaped, 5-6.5 mm long, lobes elliptic, 2-2.5 mm long, apex acute, puberulous.

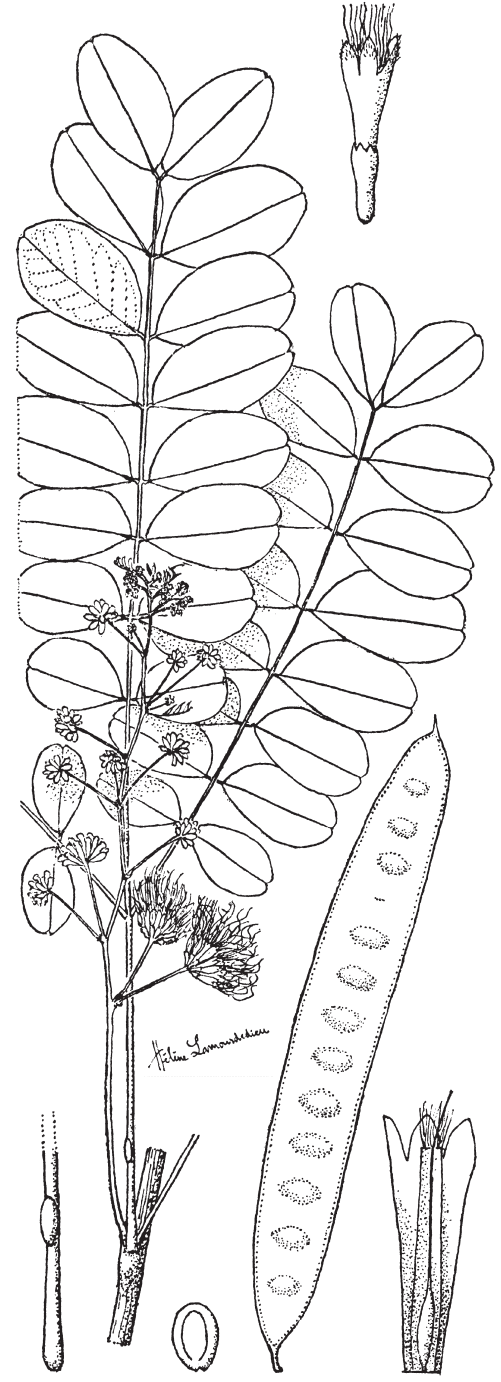

Fig. 30. Albizia procera (Roxb.) Benth. (Mimosaceae). 
Stamens greenish white, numerous, staminal tube longer than the corolla-tube. Ovary glabrous, c. $1.5 \mathrm{~mm}$ long, stipe $0.3-0.5 \mathrm{~mm}$ long. Pods flat, dark brown or red brown, strap-like to rectangular, $11-20$ by $2-2.5 \mathrm{~cm}$, very short stalk, dehiscent, glabrous, veins inconspicuous, with distinct marks over the seeds. Seeds $8-12$, obovate-elliptic, flattened, $7-8.5$ by $4.5-6.5$ by $1.5 \mathrm{~mm}$, areole 4.5 by $3 \mathrm{~mm}$, pleurogram nearly parallel to the margin, open towards the hilum.

Distribution - In India, Myanmar, South China, Taiwan, Indochina, Thailand, Malesia. In Laos: Louang Prabang, Vientiane, Savannakhet, and Champassak (Sithandone) provinces. In Vietnam: Quang Nam-Dà Nang, Quang Tri, Dông Nai, Sông Bé, and Tây Ninh provinces.

Habitat \& Ecology - Tropical rain forest, dry open forest and savannah, mixed deciduous forest, altitude up to c. 1550 m. Flowering: June, July; fruiting: August to December.

Uses - Wood hard and heavy, used in construction, for domestic utensils, vehicles, agricultural tools, for moulding, furniture, cabinets; also for making charcoal.

Specimens examined: D'Alleizette 118(P); Balansa 2179(P); Bon 11 (P); Chevalier 29771,36827 (P); Fleury 37767 (P); Hardial 574 (L); Larsen 3346 (L); Pierre 5968 (P); Poilane 11407, 27907 (L, P), 758, 7541, 11530, 13645, 18755 (P); Schmid 708 (P); Thorel s.n. (P); Vidal 1360, 4230 (P).

\section{ARCHIDENDRON F. Muell.}

\section{Archidendron clypearia (Jack) I.C. Nielsen var. clypearia - Fig. 31}

Synonyms - Inga clypearia Jack; Pithecellobium clypearia (Jack) Benth.

Vernacular names - Ben bay, Ben fay (Xieng Khouang) (L); Phân mã, Cú́t ngựa (V).

Shrubs or small trees 10-15 m high. Trunk straight and cylindrical with longitudinal grooves. Bark smooth to closely fissured, lenticellate, brown to pale grey, inner bark greenish yellow to purplish red. Branchlets angular to winged by decurrent ridges from the leaf-bases, puberulous to tomentose. Stipules sometimes present. Leaves bipinnate, paripinnate, $15-50 \mathrm{~cm}$ long, gland $1.5-2 \mathrm{~cm}$ above the base of the petiole, up to c. $5 \mathrm{~mm}$ long, flat or urceolate, elliptic or circular, upper glands below the junction of the pinnae, smaller, nearly circular, with slightly raised margins; pinnae 3-10 pairs, $2-15 \mathrm{~cm}$ long, glands just below the junctions of the petiolules, c. $0.5 \mathrm{~mm}$ diameter. Leaflets $3-10$ pairs per pinna, opposite, petiolulate, ovate to trapezoid, $0.7-8$ by $0.2-4$ $\mathrm{cm}$, base irregular cuneate, apex acuminate and often mucronate, upper surface faintly puberulous, lower surface faintly puberulous to tomentose, main vein diagonal, lateral veins prominent on lower surface. Inflorescences umbels or corymbs, with c. 10 pedicellate flowers, peduncle $1-2.5 \mathrm{~cm}$ long. Flowers uniform, pedicel 1-3(-4) $\mathrm{mm}$ long. Calyx and corolla connate, valvate. Calyx cup- to funnel-shaped, 1-3 mm long, teeth triangular to deltoid, $0.1-1 \mathrm{~mm}$ long, faintly puberulous to sericeous. Corolla funnel- to bell-shaped, $4-8 \mathrm{~mm}$ long, lobes ovate, $2-3 \mathrm{~mm}$ long, apex acute, puberulous to sericeous. Stamens many, staminal tube united with corolla tube at base. Ovary c. $1.5 \mathrm{~mm}$ long, puberulous to sericeous, stipe $1-1.5 \mathrm{~mm}$ long. Pods up to 20 by $1 \mathrm{~cm}$, coriaceous to woody, compressed, twisted in a spiral, somewhat sinuate between the seeds, outside yellowish orange, inside reddish when mature, puberulous to tomentose, dehiscing first along the ventral suture. Seeds without pleurogram, endosperm, and aril, 


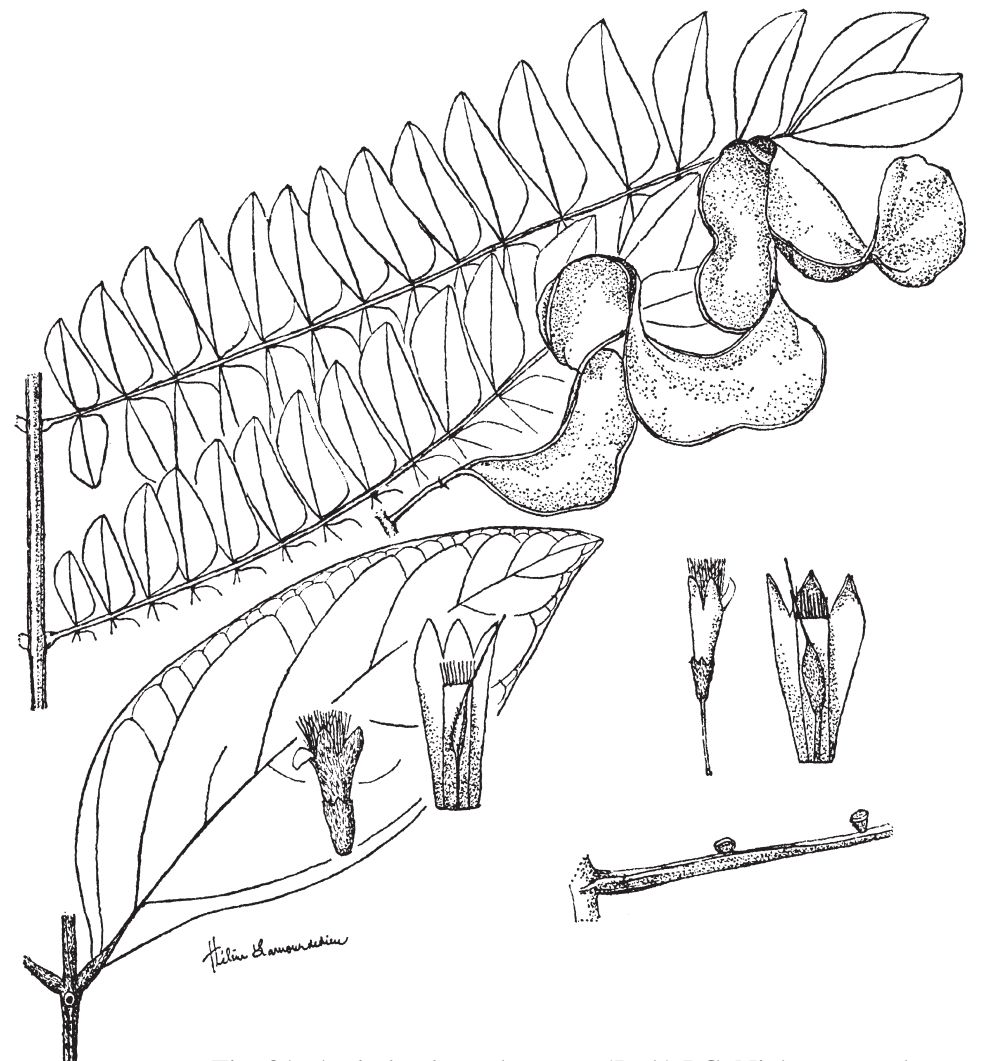

Fig. 31. Archidendron clypearia (Jack) I.C. Nielsen var. clypearia (Mimosaceae).

dangling from the funicle after dehiscence, elliptic to globose, $7-10$ by $6-9$ by $6-7$ $\mathrm{mm}$, not occupying the cavity of the pod, with a bluish black testa.

Distribution - Sri Lanka, India, Bangladesh, Myanmar, South China, Indochina, Thailand, Malesia. In Laos: Louang Namtha, Xieng Khouang, Saravane, Champassak, and Attopeu provinces. In Vietnam: almost all provinces.

Habitat \& Ecology - Primary and secondary rain forest, swamp forest, evergreen forest on clayey or grey silt, laterite, sand, and limestone soils, dry deciduous Dipterocarp forest and upper mixed deciduous forest, altitude up to $1700 \mathrm{~m}$. Flowering and fruiting throughout the year, but mostly flowering from March to May and fruiting from April to July.

Uses - The timber is used for light construction, interior joinery, furniture and cabinet work, knife handles, weapon sheaths, boxes, coffins, and fuel.

Specimens examined: Balansa 2138, 2174, 2175 (P); Bon 1601,3170, 3350 (P); Chevalier 30164 (L), 30685, 37430, 37476, 38729, 40390 (P); Clemens 3622 (P); Contest 342 (P); Eberhardt 2567, 2662, 2683, 4946, 5012 (P); Evrard 797 (L, P); Fleury 601, 30164, 38021 (P); Jacquet 634 (P); Jean 37036 (L, P); Harmand 1409, 5971, 5972 (P); Ninh et al. 9810 (L); Pételot 8853 (P); Pierre 5971 (P); Poilane 848, 1390, 2038, 5801, 5918, 13250, 15673, 18323, 22575, 23618, 23999, 25202, 26267, 26317, 28506, 29788, 30186, 31515, 32598 (P), 994, 10002, 11191, 11291, 18854 (L, P), 7226 (L); Thorel 601 (L); Tixier s.n. (P); Tsang 29201, 29903 (L, P); Vidal 2755 (P); Vinot 37 (P). 


\section{PARKIA R.Br.}

Parkia sumatrana Miq. - Fig. 32

Synonyms - Parkia dongnaiensis Pierre; P. insignis Kurz; P. macrocarpa Miq.; P. streptocarpa Hance

Vernacular names - Hua lon (Savannakhet), Som poy luang (Louang Prabang) (L); Cay thoi, Thui (Bien Hoa) (V).

Trees up to $35 \mathrm{~m}$ high, c. $40 \mathrm{~cm}$ diameter. Branchlets puberulous. Bark black, lenticellate. Leaves bipinnate, paripinnate, petioles (3.5-)5-10 cm long, gland 1-1.5 cm above the base of the petiole, elliptic, 2-7 mm long, 1 (or 2) inconspicuous glands below the

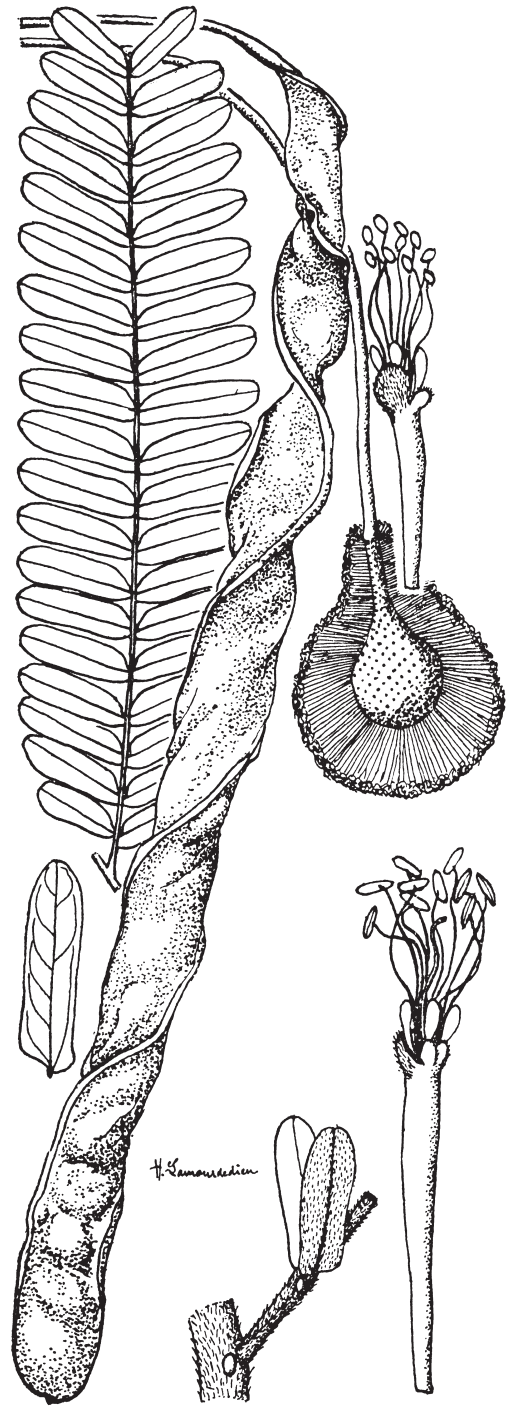
junctions of the terminal pair of pinnae, rhachis $13-30 \mathrm{~cm}$ long, pinnae $4-12$ pairs, $10-15 \mathrm{~cm}$ long, opposite or subopposite. Leaflets 12-27 pairs per pinna, opposite, elliptic, $10-28$ by $3-10 \mathrm{~mm}$, base weakly auriculate on proximal side, apex rounded or slightly retuse, often slightly emarginate, midrib slightly oblique towards apex, lateral veins prominent. Inflorescence consisting of pedunculate pendulous clavate heads, $1.5-3 \mathrm{~cm}$ wide. Flowers white, pedicellate, bracts 6-13 mm long. Sterile flowers: calyx tube narrowly funnel-shaped, c. 7 $\mathrm{mm}$ long, with linear lobes, c. $5.5 \mathrm{~mm}$ long, apex acute; staminal tube nearly $6-7 \mathrm{~mm}$ long, anthers c. 0.8 by $0.5 \mathrm{~mm}$. Bisexual flowers: calyx tube $11 \mathrm{~mm}$ long; corolla tube $12 \mathrm{~mm}$ long, lobes linear, c. $8 \mathrm{~mm}$ long, apex acute; staminal tube $7-8 \mathrm{~mm}$ long, anthers $0.5-2 \mathrm{~mm}$ long. Ovary $4 \mathrm{~mm}$ long, appressedly puberulous. Pods $35-56$ by $1.5-2 \mathrm{~cm}$ (incl. stalk), straight or slightly twisted, swollen over the seeds. Seeds obliquely longitudinal, $10-20$ by $11 \mathrm{~mm}$, testa thin and black.

Distribution - South Myanmar, Indochina, Thailand, Peninsular Malaysia, Indonesia (Sumatra, Borneo, Sulawesi). In Laos: Sayabouri, Louang Prabang, Vientiane, Savannakhet, and Attopeu provinces. In Vietnam: Quang Tri, Vinh Phu, Quang Nam-Dà Nang, Khanh Hoa, Kiên Giang, Hô Chi Minh, and Dông Nai provinces.

Fig. 32. Parkia sumatrana Miq. (Mimosaceae). 
Habitat \& Ecology - Scattered in dry evergreen forest, often along streams, hilly areas, on sandy, stony, or clayey soils, altitude 100-600(-900) m. Flowering: February or March.

Uses - Wood used for construction purposes. Fruit pulp, young leaves, and seeds edible. Bark has been used for bathing, the powdered bark has been used as local medicine, and as vermicide or against leeches.

Specimens examined: Chevalier 36760 (P); Harmand 1236, 2336 (P); Pierre 1425, 1435, 5817 (P); Poilane 1583, 3231, 6772, 11784, 11835, $13638(\mathrm{P})$; Service forestier $30076(\mathrm{P})$; Thorel s.n. (P); Vidal 1734, $2593(\mathrm{P})$.

\section{PITHECELLOBIUM Mart.}

Pithecellobium dulce (Roxb.) Benth. - Fig. 33

Synonym - Mimosa dulcis Roxb.

Vernacular names - Kham thet, Khaam theed (L); Keo tây, Me keo (V).

Small to large trees up to $25 \mathrm{~m}$ high, 45-60 cm diameter. Trunk usually straight, cylindrical, and much branched. Bark grey or greenish, splitted 3-4 mm deep, nodose, inner bark whitish, 2-7 mm thick. Branchlets numerous, slender, brownish, sparsely

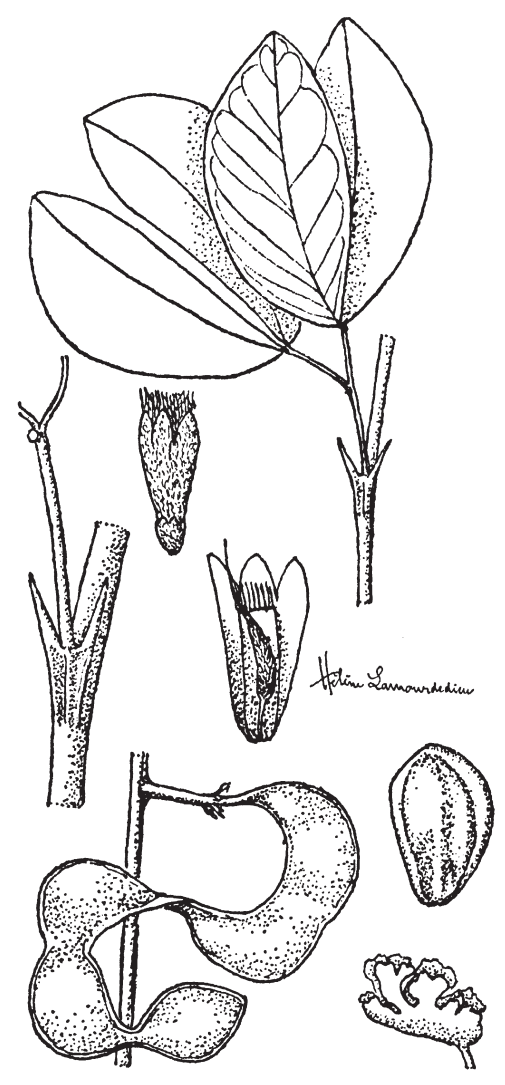
puberulous, glabrescent, armed with spinescent stipules, $1-1.5 \mathrm{~cm}$ long. Leaves bipinnate, petiole $0.3-5 \mathrm{~cm}$ long, with one gland at the junction of the pinnae, circular, with raised margins, $0.25 \mathrm{~mm}$ diam.; pinnae 1 pair, $0.2-1$ $\mathrm{cm}$ long, with one gland at the junction of the leaflets, with small terminal stipular spines. Leaflets sessile, 1 pair per pinnae, irregular elliptic to obovate-elliptic, $0.7-5$ by $0.3-2.3 \mathrm{~cm}$, chartaceous, base irregular obtuse, apex obtuseemarginate, both surfaces glabrous, lateral veins reticulate, hardly visible above, raised beneath . Inflorescence composed of pedunculate glomerules aggregated into terminal, densely puberulous panicles or racemes, peduncles $0.5-2 \mathrm{~cm}$ long, bearing a glomerule of 15-20 flowers. Flowers green. Calyx cup-shaped, 1-1.5 mm long, tomentose, teeth triangular, $0.3-0.4 \mathrm{~mm}$ long. Corolla funnel-shaped, tomentose, 3-4.5 $\mathrm{mm}$ long, lobes ovate, apex acute, $1 \mathrm{~mm}$ long. Stamens white, up to $9 \mathrm{~mm}$, tube equalling the corolla-tube. Ovary 1-3 mm long, puberulous,

Fig. 33. Pithecellobium dulce (Roxb.) Benth. (Mimosaceae). 
stipitate $0.1-0.2 \mathrm{~mm}$ long. Pods slightly flattened, $10-12(-15)$ by $1-1.6 \mathrm{~cm}$, outside dark brown, inside reddish to pinkish, glabrous or slightly puberulous, dehiscent along both sutures, swollen over the seeds. Seeds black, glossy, obovate-oblong, often asymmetric in outline, flattened, $9-12$ by $7-8$ by $1-2 \mathrm{~mm}$, funicle gradually thickened into a fleshy white or pink aril, pleurogram up to 7.5 by $3 \mathrm{~mm}$.

Distribution - Native of Central America (Mexico), now cultivated and naturalized in most of the tropics, especially in areas with a seasonal climate as India, Myanmar, Indochina, Thailand, Malaysia. In Laos: Louang Prabang and Vientiane provinces. In Vietnam: Hà Bac, Hà Nôi, Hô Chi Minh, and Quang Nam-Dà Nang provinces.

Habitat \& Ecology - Low and medium altitudes in both wet and dry areas under full sunlight, well-drained soil is best, usually clay soil, altitude 0-500 m. Flowering and fruiting: March to November.

Uses - Bark used for tanning and dying fishnets. The root bark is used to cure dysentery. The leaves when applied as a plaster can allay pain of venereal sores and relieve convulsions and taken with salt can cure indigestion, but can also induce abortion. The sweet aril is edible and used in lemonades. Timber soft but heavy used for general construction as posts or fuel. Used for hedges after pruning. Cattle and goats feed on the fallen fruits. Seed oil is also edible.

Specimens examined: Balansa 4823 (P); Chevalier 29530, 29612 (P); Davidse 9026 (L); Dupuy 265 (P); Evrard 2482 (P); Kostermans 24833, 25244 (L); Malhotra 26697 (L); Perianayagam 26623 (L); Pételot s.n. (P); Pierre 265 (P); Pottier 696 (P); Spire 891, s.n. (P); Tatemi Shimizu et al. 19470, 21666 (L); Thorel s.n. (P); Zimmerman 18 (L).

\section{SAMANEA Merr.}

\section{Samanea saman (Jacq.) Merr. - Fig. 34}

Synonyms - Albizia saman (Jacq.) F. Muell.; Enterolobium saman (Jacq.) Prain; Inga saman (Jacq.) Willd.; Mimosa saman Jacq.; Pithecellobium saman (Jacq.) Benth.

Vernacular names - Sam sa (L); Me tây (V).

Deciduous or semi-deciduous trees up to $30 \mathrm{~m}$ high,c. $100 \mathrm{~cm}$ diam., with a large crown spreading to $33 \mathrm{~m}$ in a complete canopy. Branchlets puberulous to tomentose. Stipules present. Leaves: rhachis $15-40 \mathrm{~cm}$ long, with gland(s) just below the junction of the basal pair of pinnae and distally at all other pairs of pinnae, circular, concave, c. $0.5 \mathrm{~mm}$ diam.; pinnae 3-9 pairs, c. $11 \mathrm{~cm}$ long, with gland(s) at the junctions of the leaflets. Leaflets opposite, the lowest pair ovate or elliptic, middle pairs rhomboid, terminal pair obliquely obovate, $1.5-2.5$ by $3-5 \mathrm{~cm}, 2-10$ pairs per pinnae, base half rounded and half truncate, apex rounded or obtuse, often emarginate or mucronate, main vein diagonal, lateral veins densely reticulate, raised, upper surface glabrous, lower surface densely short-pubescent. Inflorescence peduncles densely shortly yellowish pubescent, 2-5 together in the distal leaf-axils, 5-10 cm long, bearing a terminal corymb. Flowers usually heteromorphic, marginal flowers c. $3 \mathrm{~cm}$ long, pedicellate, central flowers with 7 or 8 perianth segments. Calyx funnel-shaped, 5-7 $\mathrm{mm}$ long, tomentose or woolly, teeth 5, broadly triangular, acute, $0.5-1 \mathrm{~mm}$ long. Corolla red or yellowish red, funnelshaped, 10-12 mm long, distal part tomentose or woolly, lobes triangular-ovate, c. 2 $\mathrm{mm}$ long. Stamens white at base, purple toward the top, 20-35 $\mathrm{mm}$ long, tube shorter 


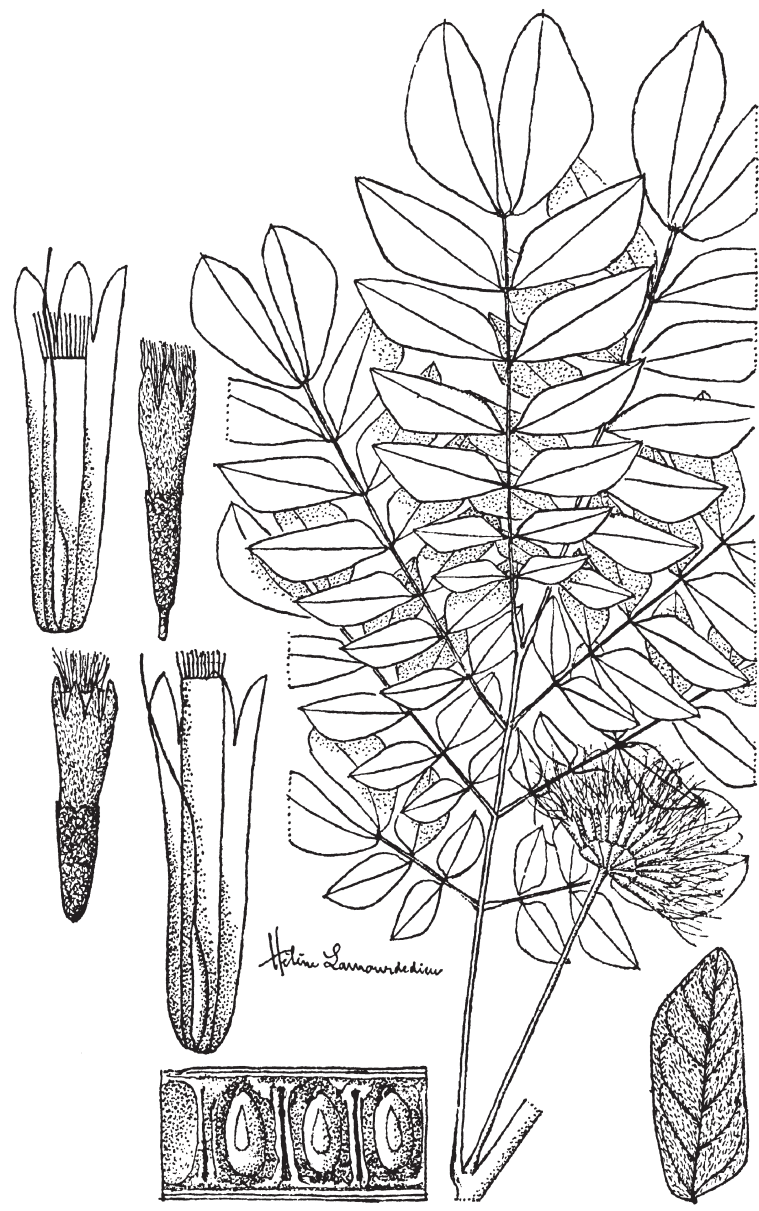

Fig. 34. Samanea saman (Jacq.) Merr. (Mimosaceae).

than the corolla-tube. Ovary sessile, glabrous. Central flower sessile. Calyx 8-9 mm long, broadly tubular, tomentose-woolly, teeth 7-8, 0.5-1 mm long, triangular, acute. Corolla c. $12 \mathrm{~cm}$ long, tubular, inside glabrous, outside tomentose-woolly. Staminal tube longer than the corolla. Ovary sessile, glabrous. Pod strap-like, $15-20$ by $1.5-2.3$ $\mathrm{cm}$ long, straight, indehiscent, outside black when mature, inside transversely septate. Seeds with pleurogram, elliptic, strongly biconvex, c. 8 by 5 by $4 \mathrm{~mm}$, brown, areole elliptic, c. 7 by $3 \mathrm{~mm}$.

Distribution - Native of northern tropical South America, now planted and appearing spontaneous all over the tropics. In Laos and Vietnam: occurring in all parts with tropical climate.

Habitat \& Ecology - Sandy, coastal areas, along roadsides, often planted, altitude up to $1800 \mathrm{~m}$. Flowering and fruiting: June to January.

Uses - The tree is widely cultivated as an ornamental along streets and around buildings. Wood hard and heavy, used in construction, furniture, boxes, and crates. Pods used as fodder for cattle, pigs, and goats. 
Specimens examined: D'Alleizette 10 (P); Chevalier 31389 (L), 37291, 38060 (P); Derral 546 (L); Evrard 2507, 2647 (P); Fleury 38047 (P); FRI 22182 (L); Heyligers 1399 (L); Hiep 123, 952 (P); Martin et al. 4316 (L); Muller 1044 (P); Perohm Kingnate 8(L); Seng Houng 93 (P); Smith 8251 (L); Sykes et al. 169773 (L).

\section{XYLIA Benth.}

Xylia xylocarpa (Roxb.) Taub. var. kerrii (Craib \& Hutch.) I.C. Nielsen - Fig. 35

Synonyms - Acacia xylocarpa (Roxb.) Willd.; Inga xylocarpa (Roxb.) DC.; Mimosa xylocarpa Roxb.; Xylia dolabriformis Benth.; X. kerrii Craib \& Hutch.

Vernacular names - Deng (L); Cẩm xe (V).

Large deciduous trees up to $30 \mathrm{~m}$ high. Trunk straight, branches slender, drooping, branchlets unarmed and without spinescent stipules. Bark creamy brown or redbrown, thin, peeling in rounded flakes, small lenticels, inner bark pink. Twigs densely

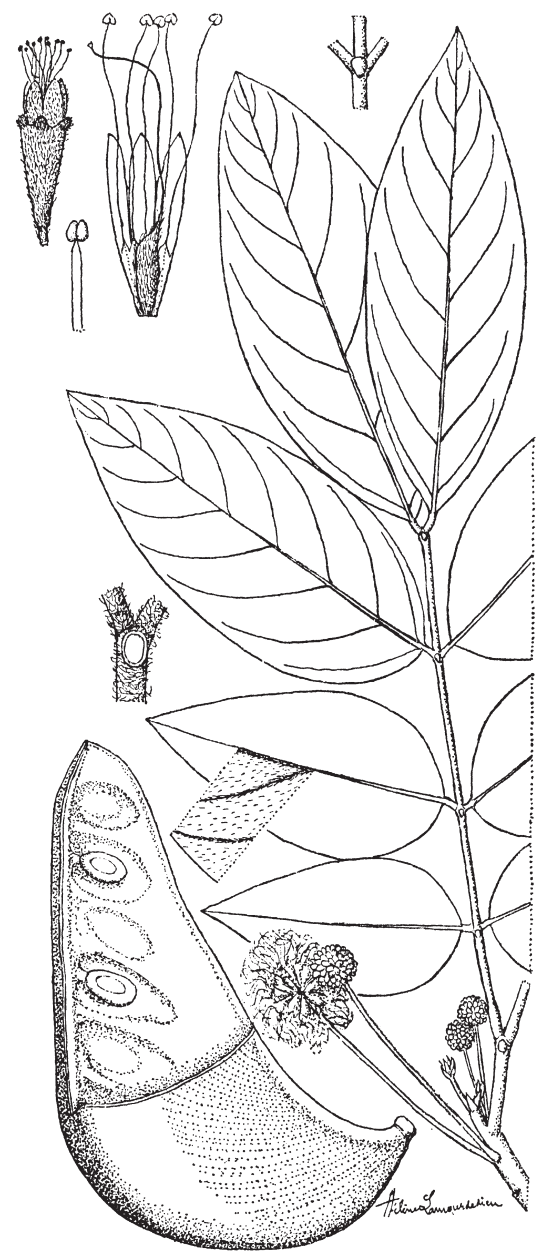
puberulous, glabrescent. Stipules filiform, 3-4 mm long. Petiole 3-8 cm long, terete, puberulous to tomentose. Leaves bipinnate, paripinnate, glabrescent, gland at the junction of the pinnae 1-3 mm diam.; pinnae 1 pair, 7-30 cm long, slightly sulcate, tomentose, glabrescent; gland just below the junction of the petiolules, 1-2 mm diameter. Leaflets 3-7 pairs per pinnae, top ones largest, narrowly ovate or elliptic, $3.8-15$ by 2.4-6.7 cm, mature leaves upper surface glabrous, lower surface puberulous to velutinous, petiolules 2-3 mm long. Young shoots densely covered with yellowish hairs. Young leaves delicate pink. Inflorescence peduncles 2.5-9 cm long, bearing heads of c. 90 sessile flowers. Bracts spoon-shaped. Calyx funnel-shaped, 2.9-4 mm long, tomentose to woolly, teeth $0.8-1 \mathrm{~mm}$ long, triangular-ovate, acute. Petals narrowly elliptic, 3.5-4.5 mm long, slightly fused at base, hairy outside. Stamens 10-12, free, 5-12 mm long, filaments very flat, anthers without glands. Ovary 2-3 mm long. Pod kitchen knife-shaped, $10-17$ by $3.5-6 \mathrm{~cm}$, thick and woody, slightly curved, tapering

Fig. 35. Xylia xylocarpa (Roxb.) Taub. var. kerrii (Craib \& Hutch.) I.C. Nielsen (Mimosaceae). 
at base, pale creamy brown at first, later dark brown, splitting suddenly into 2 parts which curl backwards, remaining on the tree for a long time. Seeds 6-10, ellipsoid, flat, $11-20$ by $7-12 \mathrm{~mm}$, dark brown.

Distribution - Myanmar, Indochina, Thailand. In Laos: Vientiane, Savannakhet, Saravane, and Champassak (Sithandone) provinces. In Vietnam: Dac Lac, Gia Lai, Dông Nai, Hô Chi Minh, and Ninh Thuân provinces.

Habitat \& Ecology - Dry evergreen forest, mixed deciduous forest, dry deciduous Dipterocarp forest, sandy deep soils, altitude up to $700 \mathrm{~m}$. Flowering: February to June; fruiting: April to December.

Uses - Wood extremely hard and durable, resistant to termites, insects, and weather. Usually used for furniture, ships and boats, bridges, railway sleepers, piles, and in construction.

Specimens examined: Chevalier 30913, 31381, 36845, 39151 (P); Dournes 276 (P); Elusel 186 (P); Fleury 29929, 30920, 39309 (P); Harmand 446 (P); Hiep 498 (P); Lecomte 2011 (P); Pierre 26, 93, 119, 120, s.n. (P); Poilane 8786, 28306 (L, P), 5636, 9301, 9349, 9541, 11560, 13777, 40841 (P); Schmid 7125 (P); Thorel $998(\mathrm{P})$; Vidal 1079, $2456(\mathrm{P})$.

\section{MORACEAE}

Evergreen or deciduous trees, monoecious or dioecious, usually with white latex in the bark, leaves, and fruits. Stipules present. Leaves simple, mostly alternate, rarely opposite, sometimes lobed. Inflorescences a cyme, catkin, or head in the leaf axils or along trunk and main branches, (male and female always in separate inflorescences on the same or different trees). Flowers minute, pale green, more or less enlarged end of the flower-stalk bearing the flower-parts, rarely interior (Ficus). Male flowers: densely clustered in dangling catkins near the end of twigs, $5-8 \mathrm{~cm}$ long. Sepals free or connate. Petals absent. Stamens 4, longer than sepals and opposite them. Pistillode central, small, or absent. Female flowers: sepals sometimes different from male flowers. Petals absent. Ovary usually superior, sometimes adnate to the sepals, ovule solitary, style(s) 1 or 2, simple or forked. Fruits simple or compound, very various, often united into large compound structures. Seed 1 .

Distribution - Almost confined to the tropics: 16 genera, c. 1100 species. In Laos and Vietnam: c. 8 genera, 125 species.

\section{BROUSSONETIA Vent.}

\section{Broussonetia papyrifera (L.) Vent.}

Synonym - Morus papyrifera $\mathrm{L}$.

Vernacular names - Sa lae (Xieng Khouang), Sa (Sayabouri), Por sa (general) (L); Dướng, Me đay (V).

Deciduous shrubs or small trees up to $20 \mathrm{~m}$ high, c. $50 \mathrm{~cm}$ diameter. Trunk cylindrical. Crown broad, spreading. All parts of the tree with milksap. Bark cream or pale brown, smooth or shallowly cracked with large lenticels, outer bark thin and fibrous, inner bark with white latex. Stipules narrowly triangular or ovate, $6-8 \mathrm{~mm}$ long, early caducous. Petioles 3-10 cm long, slender, hairy. Leaves alternate or subopposite, clustered 
near the end of twigs, broadly ovate or triangular, $6-29$ by $5-12 \mathrm{~cm}, 1-5$-lobed, base rounded or subcordate, sometimes cuneate, margin serrate, teeth variable in size, apex acuminate, young leaves densely covered with soft hairs, mature leaves thin, rough above, softly hairy below, basal veins 3-5, lateral veins 3-7 pairs. Flowers unisexual. Male flowers densely clustered in dangling catkins or spikes near the end of twigs, 5-8 $\mathrm{cm}$ long, individual flowers intermingled with stalked bracts. Sepals free in bud, hairy outside. Stamens 4, opposite the calyx lobes and longer than these, curved inwards in bud. Female flowers in globular heads, axillary, 1.2-2 cm diam., bracts subulate, pubescent at the apex, 3 or 4 teeth, stalk $0.5-1 \mathrm{~cm}$ long, individual flowers intermixed with many scales. Calyx tubular with 2-4 minute teeth, sparsely hairy outside. Ovary superior, style red, filiform, attached on the side of the ovary, much longer than calyx. Ovaries and scales connate to form a multiple fruit (syncarp), globose, about $3 \mathrm{~cm}$ diam., bright orange or red when mature. Seeds many, red, flattened.

Distribution - India, Myanmar, China, Indochina, Thailand, Malaysia, Indonesia (Java), Japan. In Laos: Sayabouri (Pak Lai), Louang Prabang, Xieng Khouang, Khammouane (Thakhek), and Attopeu provinces. In Vietnam: Hà Nôi, Quang Tri, Thanh Hoa, Khanh Hoa, Nghê An, Hà Tây, and Dac Lac provinces.

Habitat \& Ecology - A light demanding and fast-growing tree, common in open areas, secondary forest, thickets, mountain ravines, along streams in deciduous forest, preferring moisture, altitude up to $1600 \mathrm{~m}$. Natural and coppice-regeneration are strong. Flowering: November to June; fruiting: June to December.

Uses - Fibrous bark used for pulp in paper production. In Laos (Xiengkhouang prov., Phou Koud Distr.) traditionally produced paper is used to make paper altars and umbrellas (khan gnou) needed during religious ceremonies. Bark and fibres are exported. The inner bark is beaten by sticks to free the fibres. These are used in making 'tapa' cloth or 'kappa' in ancient Polynesia. Leaves are used as food for pigs and rabbits. Fruit, bark, and root are used in medicine as tonic for kidney problems and as diuretic. Seeds contain oil, used in soap and in lacquer oil production.

Specimens examined: Balansa 2462, 2463, 4111 (P); Bon 2934, 3202, 4992 (P); Chevalier 32422 $(\mathrm{P})$; Clemens $4128(\mathrm{P})$; Dournes $378(\mathrm{P})$; Eberhardt 3430, 4018, $4529(\mathrm{P})$; Fleury $30187(\mathrm{P})$; Harmand 1296, 3295 (P); Ninh \& Hoang 11450 (L); Pételot 23 (P); Poilane 1143, 1194, 2033, 6293, 7049, 10795, 31531 (P); Pottier 811 (P); Spire 419 (P); Vidal 1265, 2082 (P).

\section{MYRISTICACEAE}

Trees or shrubs 3-40 m high, dioecious, sometimes buttresses present. Bark usually with copious red or orange sap. Branches more or less horizontal, usually whorled, crown often pyramidal. Stipules absent. Leaves simple, alternate, usually distichous, margin entire, often tomentose on both surfaces when young and later glabrous or sometimes tomentum remaining on the lower surface. Male inflorescences axillary amongst or behind the leaves, or on the stems, panicles, or racemes, pedunculate or sessile, with scars of previous pedicels and bracts; flowers usually in racemose umbels; bracts present, often caducous; bracteole absent or present; pedicels usually present. Female inflorescences similar to male, usually less branched and shorter; flowers smallish. Perianth gamophyllous, 2-5-lobed fused at the base, sometimes split to the base, the female 
flowers usually larger than the male ones, inside creamy or red. Stamens many, filaments united into a column. Ovary single, superior, subglobose, style short or absent, stigma 2-lobed, ovule 1, at the base of the ovary. Fruits a more or less woody capsule, elliptic, splitting into 2 sections, pericarp usually thick, coriaceous, glabrous or hairy, yellow or red when mature. Seed single, large, aril and seed aromatic, aril red or orange-red, fleshy, covering the seed, variously lobed or entire, endosperm ruminate.

Distribution - In all tropical areas: 20 genera, 500 species. In Laos and Vietnam: c. 2 genera, 20 species.

\section{KEY TO THE GENERA}

1a. Bracteole absent. Leaves when dry easily breaking into pieces, lower surface brown, upper surface dull. Inflorescences a loose panicle . . . . . . 1. Horsfieldia

b. Bracteole present in the apical part of the pedicel. Leaves when dry not easily breaking into pieces, lower surface usually glaucous or whitish, upper surface glossy. Inflorescences short umbel-like racemes

2. Knema

\section{HORSFIELDIA Willd.}

Horsfieldia amygdalina (Wall.) Warb. - Fig. 36

Synonyms - Horsfieldia thorelii Lecomte; H.tonkinensis Lecomte

Vernacular names - Han, Hant (Savannakhet), Lueat nok (Vientiane) (L); Sang máu, Máu chó lá lón (V).

Small to large trees 5-30 m high. Twigs towards apex terete, first hairy, then glabrescent. Bark finely striate and with lenticels. Leaf bud hairy. Leaves broadly elliptic, $9-23$ by $2.5-9 \mathrm{~cm}$, when dry easily breaking into pieces, base cuneate, apex acute or acuminate, upper surface dull, olive green or dark brown or blackish when drying, lower surface brown, soon glabrescent, midrib flat to slightly raised above, secondary veins 7-14 pairs, venation faintly reticulate. Inflorescences a loose panicle, axillary, thinly pubescent with pale hairs. Bracteoles absent. Male inflorescences 4-22 cm long. Female inflorescences 1-6 cm long. Male flowers short-obovoid or globose, 1.5-2.5 by $1.5-2 \mathrm{~mm}$, lobes splitting the bud to c. halfway, androecium globose or obovoid, largely solid, $0.8-2$ by $0.8-1.3 \mathrm{~mm}$, anthers $10-15$, sessile. Female flowers ellipsoid, $2-3$ by $2 \mathrm{~mm}$. Ovary glabrous. Fruits ellipsoid, $2-6$ by $1.6-2.6 \mathrm{~cm}$, glabrous, brown on drying, stalk 2-4 mm long. Seed ovoid, aril entire.

Distribution - India, Bangladesh, Myanmar, South China, Indochina, Thailand. In Laos: Savannakhet province. In Vietnam: Kiên Giang, Ninh Binh, and Dông Nai provinces.

Habitat \& Ecology - Evergreen and deciduous forest, altitude up to $650 \mathrm{~m}$. Flowering: September, October; fruiting: January to May.

Uses - Wood used for temporary construction and general furniture. Seeds contain a solid oil used for industrial purposes.

Specimens examined: Pierre 56, 1812, 5434 (P); Poilane 10, 1348, 8699, 18160, 18308, 18615, 22394, $23253(\mathrm{P})$. 


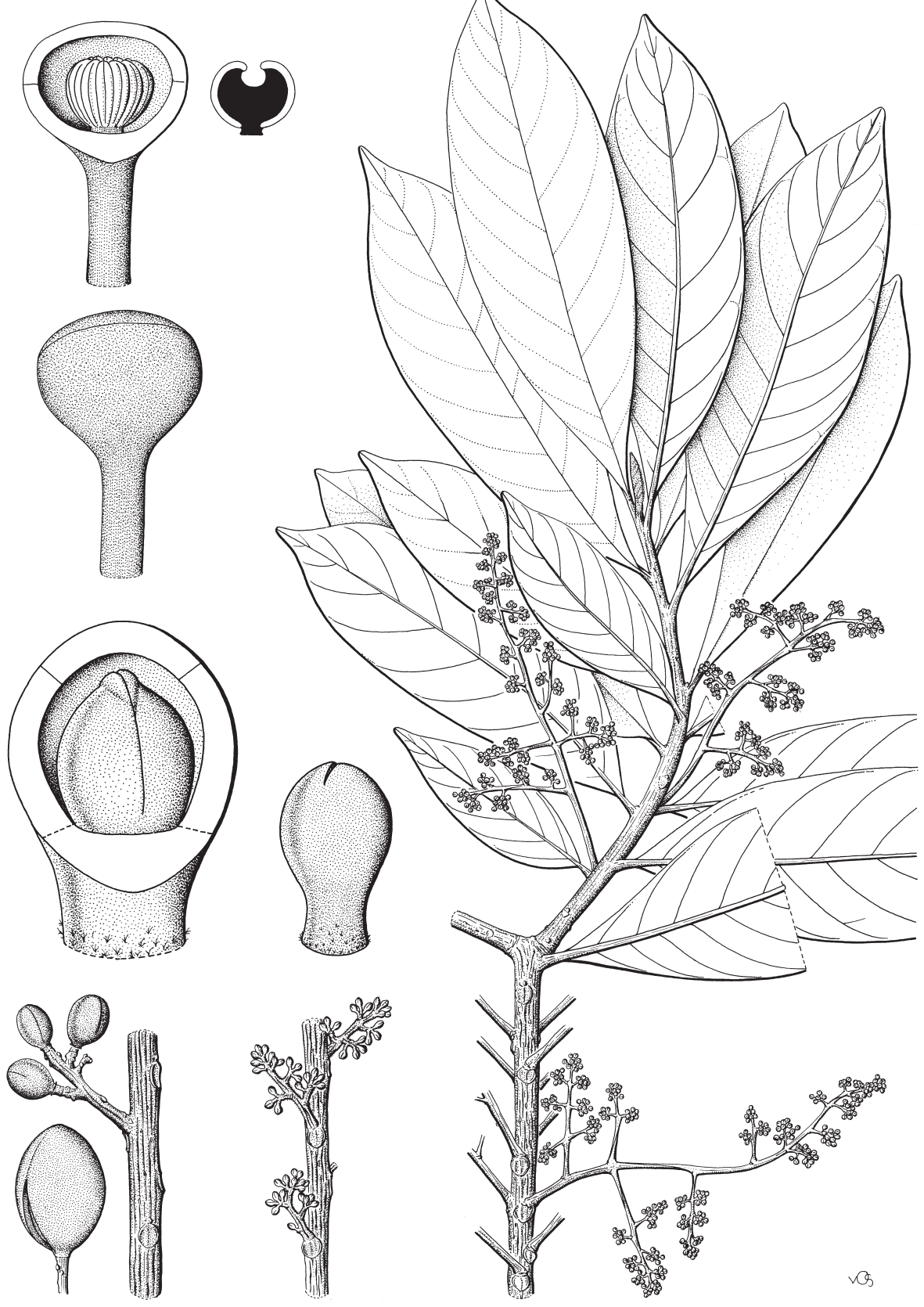

Fig. 36. Horsfieldia amygdalina (Wall.) Warb. (Myristicaceae). 


\section{KNEMA Lour.}

Knema globularia (Lam.) Warb.

Synonyms - Knema corticosa Lour.; Myristica corticosa (Lour.) Hook.f.; M. globularia Lam.

Vernacular names - Thom luat (Savannakhet), Luat ma (Vientiane, Na Hai) (L); Máu cho lá nhỏ, Máu chó lá bé (V).

Trees 5-20 m high, 30-35 cm diameter. Trunk straight, fluted. Young branches yellow-brown, first tomentose, latter glabrous. Bark usually smooth, rarely cracked, never flaking. Leaves narrowly elliptic or narrowly ovate, $6-19$ by $2-4 \mathrm{~cm}$, thin, coriaceous, when dry not easily breaking into pieces, base cuneate, margin entire, apex acuminate, upper surface glossy and dark green, usually pale brown with blackish metallic shine when dry, lower surface pale green, when dry usually glaucous or whitish, midrib sunken above, secondary veins $10-15$ pairs, faint, flat or sunken above, prominent beneath. Inflorescences short umbel-like, racemes, usually at least partly 1-5 mm pedunculate, simple or furcate, to $10 \mathrm{~mm}$ long. Male inflorescences with 5-20 flowers. Female inflorescences with 1-10 flower(s). Male flowers: pedicel 2-11 mm long, bracteole above median, bud broadly obovoid, 3-5 mm diam., creamy or reddish inside, lobes splitting the bud to c. $2 / 3$ deep, staminal disc circular or 3-angled, flat, including anthers $1.5-2.5 \mathrm{~mm}$ diam., anthers 8-13, free. Female flowers: pedicel 1.5-4 $\mathrm{mm}$ long, bracteole nearly apically, bud ellipsoid-ovoid, $4-5$ by $2.5-3.5 \mathrm{~mm}$. Ovary ovoid to globose, tomentose. Style short, stigma lobed. Fruits ellipsoid, subglobose, or sometimes pear-shaped, $1.2-2$ by $1-1.5 \mathrm{~cm}$, stalk 3-20 mm long, pericarp thin. Seed smooth or glossy, aril entire.

Distribution - India, Myanmar, China, Indochina, Thailand, Peninsular Malaysia, Singapore, Indonesia (Sumatra, Java). In Laos: Vientiane, Vientiane Municipality, and Savannakhet provinces. In Vietnam: Vinh Phu, Dông Nai, Nghê An, Quang Tri, Lào Cai, Thanh Hoa, and Khanh Hoa provinces.

Habitat \& Ecology - Primary and secondary evergreen forest, along river banks, in hilly forest, altitude 150-1200 m. Flowering: June to December; fruiting: December to June.

Uses - Wood used for general furniture. Seeds used in medicine to cure scabies and other skin-diseases.

Specimens examined: Balansa 4198 (P); Chevalier 43, 37053, 37054, 38283, 38438, 38566, 39179 (P); Fleury 5472, 30009, 30114, 30145, 38000, 38438, 39348 (P); Harmand 602 (P); Hiep 429 (P); Muller 898, 1002 (P); Pételot 1546 (P); Pierre 260, 5434 (P); Poilane 119, 131, 1581, 1741, 6600, 10198, 10486, 17567, 20004, 25188, 29203, 29919 (P); Vidal 1756, 2250 (P).

\section{MYRTACEAE}

Trees or shrubs. Stipules absent. Leaves simple, opposite (rarely alternate or whorled), entire, pinnately veined, often with an intramarginal vein, with dots. Inflorescences complex cymes, sometimes racemes, many-flowered, rarely solitary. Flowers white or pink, regular, bisexual, rarely unisexual, (3- or) 4- or 5- (or 6-)merous. Sepals and petals free or forming a deciduous cup, usually orbicular. Stamens usually many, free or united at the base into 4 or 5 bundles, arranged at the edge of the hypanthial cup, 
anthers usually attached at the back. Ovary usually more or less inferior, 2-5-locular, ovules two to many per locule; style 1, often filiform, stigma minute and head-like. Fruit usually a berry or capsule, rarely a drupe, often with persistent sepal lobes. Seed $(s) 1$ to many.

Distribution - Worldwide: Large tropical family: c. 70 genera, 4620 species. In Laos and Vietnam: c. 12 genera, 69 species.

\section{SYZYGIUM Gaertn.}

Synonyms - Caryophyllus L.; Eugenia auct. non L.; Jambosa Adans.; Opa Lour.

Shrubs to large trees. Trunk sometimes buttressed or fluted. Bark various, often papery, flaky, or peeling; sapwood pinkish, red, yellow, or white, often turning purplish on exposure. Leaves opposite, rarely spirally arranged or whorled, intramarginal veins usually present, sometimes absent. Inflorescences many-flowered terminal or axillary panicles or racemes, sometimes few-flowered cymes. Bracts and bracteoles usually caducous, sometimes persistent. Flowers 4- or 5-merous, sessile or pedicellate, glabrous in bud. Calyx lobes broadly funnel-shaped or club-like, rarely cylindrical, persistent or caducous early. Petals free, sometimes united in a cap-like structure. Stamens free, usually many. Ovary 2- (rarely 3- or 4-)locular, ovules few or many per locule, style as long as or shorter than the stamens. Fruit a berry, variously shaped, apex usually crowned by the persistent remnants of the calyx tube or by enlarged calyx lobes, or both. Seed(s) 1 or 2 , rarely more.

\section{KEY TO THE SPECIES}

1a. Leaf elliptic or ovate-elliptic, about 2 times longer than broad, secondary veins 19-30 pairs, intramarginal vein 1 . Inflorescences terminal or axillary panicles.

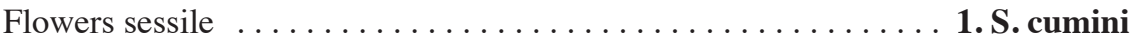

b. Leaf narrowly ovate, about 4 times longer than broad, secondary veins 11-18 pairs, intramarginal vein(s) 1 or 2 . Inflorescences terminal racemes. Pedicel 3-13 mm long

2.S. jambos

\section{Syzygium cumini (L.) Skeels}

Synonyms - Eugenia cumini L.; E. jambolan Lam.; Myrtus cumini L.

Vernacular names - Sa (Xieng Khouang), Sa leng, Va (L); Vối rù̀ng (V).

Trees up to $35 \mathrm{~m}$ high. Twigs angular when young, later terete. Bark grey, slightly flaking, inner bark reddish. Petiole 6-28 mm long. Leaves elliptic or ovate-elliptic, 6-13 by $3-7 \mathrm{~cm}$, index 2 , base cuneate, acute, or rounded, apex shortly acuminate, secondary veins 19-30 pairs, intramarginal vein 1. Inflorescences terminal or axillary panicles, several together, shorter than the leaves, 4-10 cm long, peduncles 3-10 mm long, branches and branchlets striate. Bracts triangular, 7 by $10 \mathrm{~mm}$. Bracteoles triangular, 6 by $4 \mathrm{~mm}$. Flowers white or pale yellow, sessile. Hypanthial cup 2.4-5.1 mm long, funnel-shaped. Pseudostipe 1-2 mm long. Sepals 4, triangular or rounded, obscure, 2.5-6 $\mathrm{mm}$ long. Petals 4, joined into a cup, 1.4-2.8 mm long, early caducous, 5-19 gland 
dots per petal. Outer stamens $4-6 \mathrm{~mm}$ long, anthers elliptic, $0.4-0.5 \mathrm{~mm}$ long. Ovary 2-locular, ovules 10-18 per locule, style 1.8-6.5 mm long. Fruits ovoid or ellipsoid, 8-15 mm long, pink turning dark red-purple or black when ripe. Seed 1 , ellipsoid.

Distribution - Widely distributed in the Indo-Malayan region. In Laos: Sayabouri (Pak Lay Distr.), Xieng Khouang, Vientiane, Savannakhet (Sepone Distr.), and Attopeu provinces. In Vietnam: Vinh Phu and Dông Nai provinces.

Habitat \& Ecology - Widespread in many types of forest. Often found in open and semi-open deciduous evergreen forest, conifer-broadleaved forest, or individual trees on grassland, altitude 0-1100 m. Flowering: March, April; fruiting: June, July.

Uses - Wood is pink and hard, used for fuel, construction, and furniture. The fruits are edible. The juice of the leaves is used for treatment of dysentery and for cleaning external wounds. Local people treat mild forms of diabetes.

Specimens examined: Dieu 56 (P); Harmand 3190, s.n. (P); Hosseus 436 (P); Pételot 4679 (P); Pierre 14, 1812 (P); Poilane 13480, 22394, 23253 (P).

\section{Syzygium jambos (L.) Alston}

Synonyms - Eugenia jambos L.; Jambosa vulgaris DC.

Vernacular names - Chieng, Kieng (L); Gioi (V).

Trees up to15 m high. Twigs slender, compressed, or angular. Bark whitish grey or brown. Petiole $7-14 \mathrm{~mm}$ long. Leaves narrowly ovate, $8-20$ by $1.5-5 \mathrm{~cm}$, index 4 , base cuneate or obtuse, apex acute or acuminate, secondary veins 11-18 pairs, intramarginal vein(s) 1 or 2. Inflorescences terminal racemes, 3-8-flowered, rarely 1-flowered, up to $6 \mathrm{~cm}$ long; peduncles 30-50 mm long, rhachis and branches terete. Bracts triangular, 7 by $10 \mathrm{~mm}$. Bracteoles triangular, 6 by $4 \mathrm{~mm}$. Flowers white or pale yellow, pedicel 3-13 mm long. Hypanthial cup 12-14 mm long, broadly funnel-shaped. Pseudostipe 4-6 mm. Sepals 4, semi-orbicular, 5-8 mm long. Petals 4, free, orbicular, 15-17 mm long, base thick, more than 200 gland dots per petal. Outer stamens $16-37 \mathrm{~mm}$ long, anthers elliptic, 1-1.2 mm long. Ovary 2-locular, ovules c. 28 per locule, style $27-43 \mathrm{~mm}$ long. Fruits depressed globose, 3-6 cm diam., pale pink when ripe. Seed(s) 1 or 2.

Distribution - Native to the Indo-Malayan region, widely cultivated in tropical regions. In Laos: Vientiane and Champassak (Lakhon Distr.) provinces. In Vietnam: Hà Bac, Hà Nôi, Ninh Binh, Son La, Thanh Hoa, Nghê An, Dac Lac, and Dông Nai provinces.

Habitat \& Ecology - Usually planted as a fruit-tree in villages or plantations. Sometimes escaping cultivation and growing wild along streams or rivers. Suitable on wet and deep soils near river banks. Light demanding when mature. Altitude up to 300 m. Flowering: April, May; fruiting: July, August.

Uses - Wood is used locally in general construction. Fruit edible, sweet and delicious. The tree is planted as wind shelter.

Note - According to Parnell \& Chantaranothai, Flora of Thailand 7 (2002) the width of the leaves should be $3-4.5 \mathrm{~cm}$. We observed some specimens with much narrower, 1.5-2 cm wide leaves (e.g. Spire 703, 1025). Other characters, however, are not different. 
Specimens examined: Balansa 2861 (P); Bon 359,3312,4191,30092 (P); Butreau 12 (P); Chevalier 30092 (P); Clemens 3509 (P); Eberhardt 2778 (P); Fleury 29923, 37551 (P); Lei 308 (P); Molliard s.n. (P); Pételot 1832, s.n. (P); Pierre 93, 1962, s.n.(P); Schmid 996 (P); Simond 184 (P); Spire 703, 1025 (P); Thorel 2790, s.n. (P).

\section{PAPILIONACEAE}

Herbs, shrubs, or trees. Stipules usually present. Leaves spirally arranged, simple or compound, pinnate or digitate. Flowers mostly pea-flower-shaped, in terminal or axillary 1- to numerous-flowered inflorescences, usually bisexual. Sepals joined to form a cup or tube with 5 teeth. Petals mostly 5, imbricate, free or almost so, 2 lowermost forming together the keel (carina) enclosed by the 2 more or less parallel lateral ones (wings, alae), topmost petal (standard, vexillum) in bud embracing the other ones. Stamens mostly 10 (rarely 8 or 9), connate or free, all perfect or partially reduced to staminodes. Ovary superior, 1-celled, with 1 to many ovules. Fruit a pod. Seed $(s) 1$ to numerous, septate between the seeds or not, or articulate, when mature dehiscent or not, frequently breaking up into 1-seeded articles. Seed coat with complex structure in region of scar (hilum), in transverse section of a mature seed the albumen is visible on either side of the embryo.

Distribution - Worldwide: c. 505 genera, c. 13,800 species. In Laos: 70 genera, 267 species. In Vietnam: 86 genera, 385 species.

\section{KEY TO THE GENERA}

1a. Trunk and branches unarmed. Leaves imparipinnate. Stipels absent. Flowers white or bright yellow. Fruits flat $\ldots \ldots \ldots \ldots \ldots \ldots \ldots \ldots \ldots \ldots \ldots \ldots \ldots \ldots \ldots \ldots \ldots$

b. Trunk and branches armed. Leaves trifoliolate. Stipels present, gland-like. Flowers red or orange. Fruits strap-like, not flat $\ldots \ldots \ldots \ldots \ldots \ldots \ldots$. Erythrina

2a. Exudate red. Fruits winged, rounded. Seed usually $1 \ldots \ldots \ldots$. Pterocarpus

b. Exudate absent. Fruits not winged, linear. Seeds usually more than 1

1. Dalbergia

\section{DALBERGIA L.f.}

Trees, erect or scandent shrubs to woody climbers, sometimes spiny. Stipules usually small, caducous, rarely persistent. Leaves alternate, imparipinnate. Leaflets alternate or subopposite, without stipels. Inflorescences axillary or terminal panicles, racemes. Bracts and bracteoles small, most often caducous. Flowers numerous and small to very small, or relatively large, often fragrant. Calyx bell-shaped, 5-lobed, the upper ones broader and shorter than the lower 3, connate at the base, the lowest lobe usually longest. Corolla usually white, sometimes purple, green or yellowish, or violet. Standard with or without basal callosities, claw well-developed. Wings free, elliptic, base truncate, auriculate or hastate. Keel petal mostly free, obtuse, only joined at the tip. Stamens 9 or 10, monodelphous or diadelphous, sometimes connate near the base only. Anthers globular, small, uniform, erect, didymous, dehiscing with a small transverse slit. Ovary 
stalked, few-ovuled, style short, curved, glabrous, stigma small, capitate. Fruits linear, indehiscent, usually thin and flat, 1-4-seeded, more or less in the centre, not thickened or winged at the sutures. Seeds compressed laterally, reniform, radicles bent inwards.

Distribution - Worldwide: c. 300 species. In Africa: c. 41 species. In Asia and Australia: 102 species of which 36 occur in Malesia. In Laos: 15 species. In Vietnam: 27 species.

\section{KEY TO THE SPECIES}

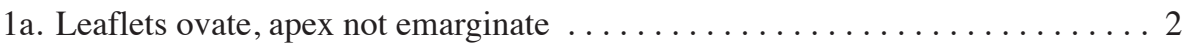

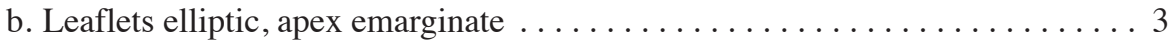

2a. Leaflets 7-10. Secondary veins 7-9 pairs. Calyx glabrous. Apex of standard emarginate, callosities absent. Stamens monodelphous. Ovary glabrous. Fruits very

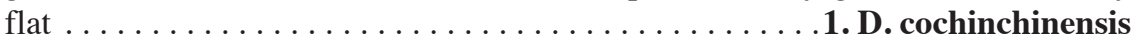

b. Leaflets $13-17$. Secondary veins $9-12$ pairs. Calyx hairy on teeth. Apex of standard rounded, callosities present. Stamens diadelphous. Ovary hairy along the margin. Fruit bulging over seeds $\ldots \ldots \ldots \ldots \ldots \ldots \ldots \ldots \ldots$. oliveri

3a. Calyx hairy on teeth. Standard obovate, callosities absent. Stamen 9, monodelphous. Ovary glabrous. Fruit very flat. Seeds near the margin of fruit . . 2. D. cultrata

b. Calyx hairy all over. Standard rounded or orbicular, callosities present. Stamens 10, diadelphous. Ovary hairy along the margin. Fruit bulging over the seeds. Seeds in the central part of fruit $\ldots \ldots \ldots \ldots \ldots \ldots \ldots \ldots \ldots$. lanceolaria

\section{Dalbergia cochinchinensis Pierre - Fig. 37}

Synonym - Dalbergia cambodiana Pierre

Vernacular names - K(h)anhung $(\mathrm{L})$; Trắc, Sưa nam bộ $(\mathrm{V})$.

Large, evergreen trees $15-30 \mathrm{~m}$ high, c. $60 \mathrm{~cm}$ (sometimes up to $120 \mathrm{~cm}$ ) diam., profusely branched, crown spherical. Bark brownish yellow, longitudinally fissured, sometimes peeled off into fragments. Stipules caducous. Petioles $2.5-5 \mathrm{~cm}$ long, rhachis $6.5-15 \mathrm{~cm}$ long, glabrous. Leaves $13-25 \mathrm{~cm}$ long. Leaflets 7-9, coriaceous, ovate to narrowly ovate, $3-8(-10)$ by $1.8-4(-5) \mathrm{cm}$, apex obtuse or short acuminate, base obtuse or rounded, glabrous, secondary veins 7-9 pairs, venation reticulate below, petiolules 3-4 mm long. Inflorescences axillary or terminal panicles, $10-20 \mathrm{~cm}$ long; bracts and bracteoles early caducous; pedicels c. $1 \mathrm{~mm}$ long. Flowers white or whitish, 5-6 mm long, sweet-smelling, stalk c. 2 mm long, sparsely short hairy. Calyx c. $5 \mathrm{~mm}$ long, glabrous, sparsely hairy. Petals with straight claws; standard obovate or rectangular $4-6$ by $2.5-3.5 \mathrm{~mm}$ (incl. claw c. $1.5 \mathrm{~mm}$ long), callosities and auricles absent, apex obtuse or rounded; wings machete-shaped, or irregular elliptic, 5 by 1.5 $\mathrm{mm}$ (incl. claw), apex rounded; keel petals $5-6$ by $2 \mathrm{~mm}$ (incl. claw), auricles present, apex rounded. Stamens 10, 5-6 mm long, monodelphous. Ovary stipitate, c. $3 \mathrm{~mm}$ long, glabrous, stalk c. $3 \mathrm{~mm}$ long, sparsely hairy, with $2-4$ ovules, style c. $1.5 \mathrm{~mm}$ long, glabrous. Pods very flat, narrow, straight, $4-7.5$ by $0.8-1.2 \mathrm{~cm}$, both margins parallel at the seed areas, wall thin, glabrous, calyx persistent at the base of the stalk. Seeds reniform, 6 by $4 \mathrm{~mm}$ in the central part, brown or reddish. 


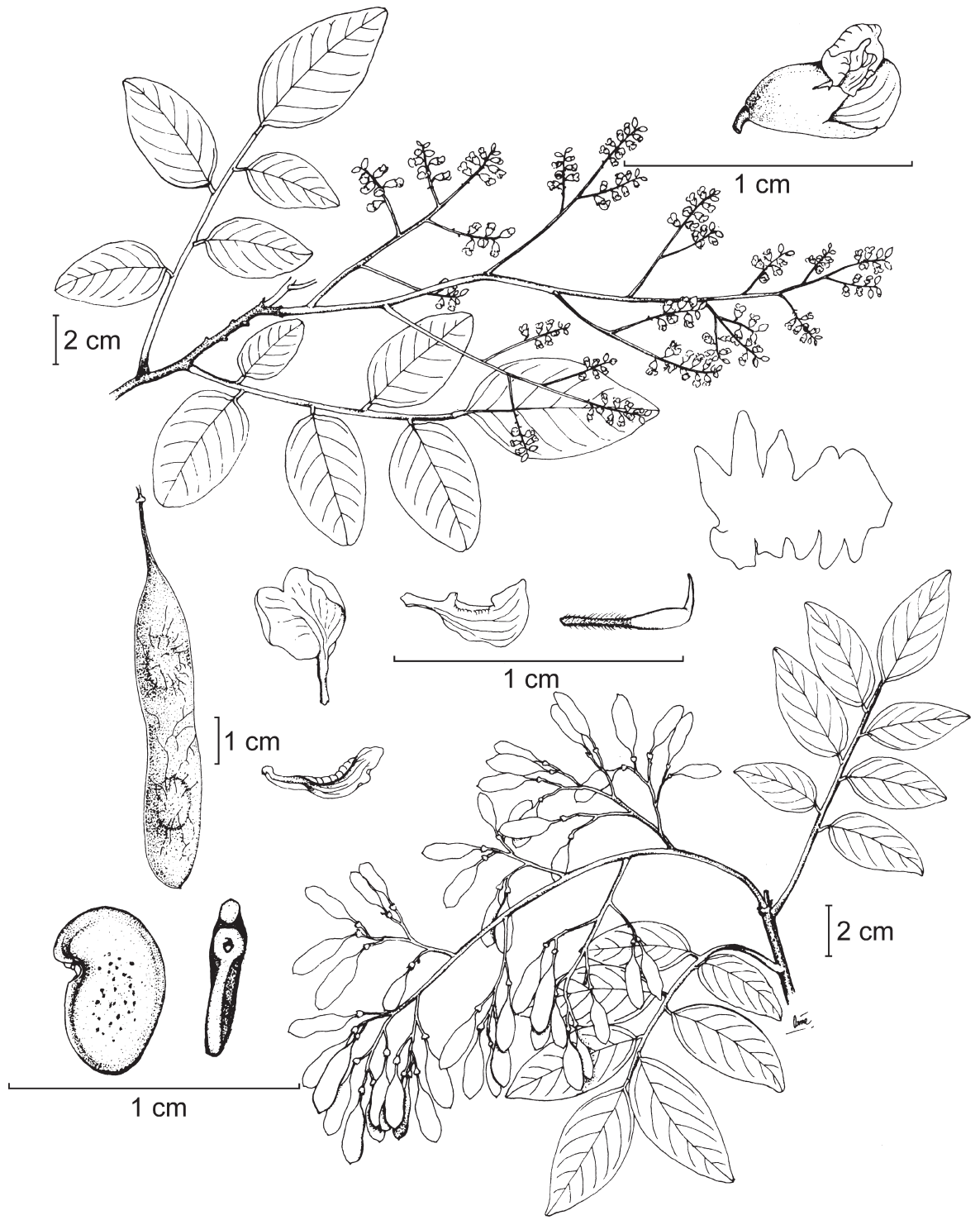

Fig. 37. Dalbergia cochinchinensis Pierre (Papilionaceae).

Distribution - Thailand, Cambodia. In Laos: Savannakhet (Ban That) province. In Vietnam: Dac Lac, Lâm Dông, Gia Lai, Kon Tum, Dông Nai, Hô Chi Minh, and Bà Ria-Vung Tàu provinces.

Habitat \& Ecology - Shade tolerant when young, later inclining to be light demanding and drought tolerant, growth rate rather slow, coppice-regeneration very strong. In mixed deciduous forest, altitude 50-500 m. The tree grows sparsely in open and 
semi-deciduous forest, occasionally in pure stands. Preferring deep sandy clay soil and calcareous soil. Flowering: March to August; fruiting: September to December.

Uses - Used for furniture (beds, wardrobes, desks, etc.), wood turnery, fine-art articles, musical instruments, and sewing-machines.

Specimens examined: Chevalier 30096, 40927 (P); Dournes s.n. (P); Hoi 175 (P); Lefèvre 138, 320 (P); Morange 313345 (P); Pierre 1710 (L, P); Poilane 22353 (P); Schmid s.n. (P); Talmy s.n. (P); Thorel 398, s.n. (P).

\section{Dalbergia cultrata Benth. - Fig. 38}

Synonym - Dalbergia fusca Pierre

Vernacular names — Lamz (Louang Prabang), Pik nhang (Xieng Khouang) (L); Cầm lai giao, Trắc giao (V).

Deciduous trees 10-30 m high, with straight trunk, crown open, narrow. Bark creamy, quite smooth with horizontal wrinkles, inner bark reddish brown; heartwood dark purple. Young twigs, branchlets, and shoots hairy. Petioles slender, green, pubescent.

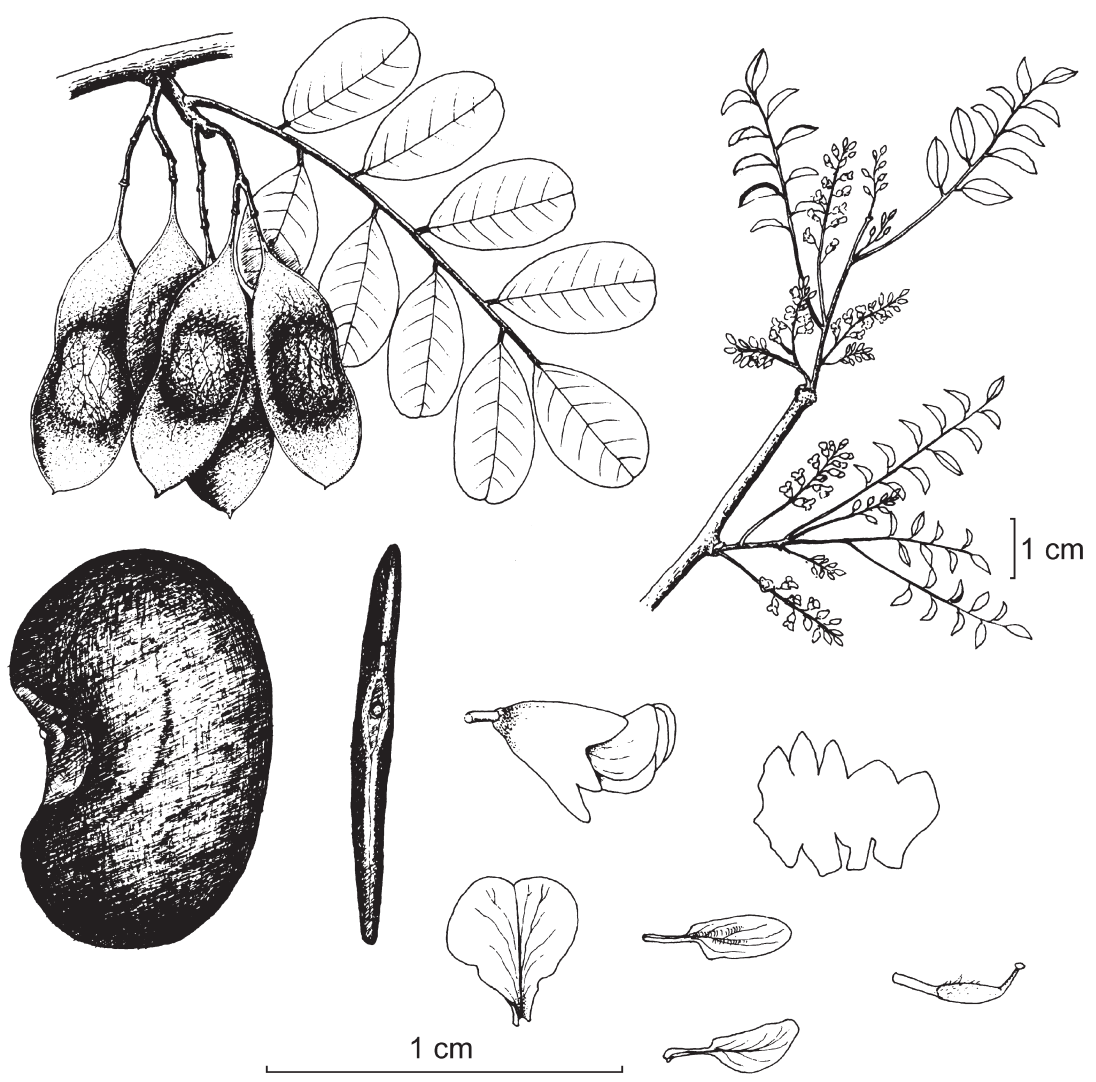

Fig. 38. Dalbergia cultrata Benth. (Papilionaceae). 
Leaves $10-20 \mathrm{~cm}$ long. Leaflets alternate or subopposite, 3-6 pairs, narrowly elliptic, $2.5-5$ by $1.5-2.5 \mathrm{~cm}$, apex obtuse or rounded, emarginate, base obtuse or rounded, upper surface dark green, glabrous, lower surface glabrescent-pubescent when mature, secondary veins $9-12$ pairs, smaller veins easily visible; petiolules $2-3 \mathrm{~mm}$ long. Inflorescences axillary, panicles, 2-8 cm long. Bracts and bracteoles filiform, $1 \mathrm{~mm}$ long, persistent, tomentose. Pedicel 1-2 mm long, Flowers white or pink, 5-6 mm long, appearing before young leaves. Calyx tube $3-5 \mathrm{~mm}$ long, glabrous, all teeth nearly the same length, sparsely hairy. Standard obovate or subreniform, 5 by $3 \mathrm{~mm}$ (incl. claw $1.5 \mathrm{~mm}$ long), callosities absent, apex slightly emarginated. Wings and keel petals machete-shaped, 4.5 by $1.5 \mathrm{~mm}$ (incl. claw $1.2 \mathrm{~mm}$ long). Stamens 9 , monodelphous. Ovary glabrous, 10-12 mm long, stipe long, $3 \mathrm{~mm}$ long, ovules 2 or 3. Fruits stalked, linear often slightly curved, $2.5-8.5$ by $1.5-2 \mathrm{~cm}$, coriaceous, glabrous, brown or greyish when dry, very flat, slightly veined over seeds, stalk $0.5-1.5 \mathrm{~cm}$ long. Seed $(s)$ $1-3$, reniform, near the margin of fruit, $8-10$ by $2-6 \mathrm{~mm}$.

Distribution - Myanmar, China (Yunnan), Indochina, Thailand. In Laos: Sayabouri (Pak Lai), Louang Prabang (Phou Khouang), Xieng Khouang (Moung Soui, Phou Kabo, and Moung You), and Savannakhet provinces. In Vietnam: Dac Lac, Lâm Dông, and Dông Nai provinces.

Habitat \& Ecology - In mixed forest, usually found in open areas, altitude 100$1500 \mathrm{~m}$. Flowering: January to March; fruiting: March to September.

Uses - Wood reddish black, durable, good quality for precious furniture.

Specimens examined: Poilane 11527 (L, P), 12093, 20084 (P), 30948, 32382 (L); Pierre 1706 (L); Thorel s.n. (P); Vidal 1659, 2600 (P).

\section{Dalbergia lanceolaria L.f.}

Vernacular names - Kaboz, Kamphiz (Louang Prabang), Pa dong khao (Vientiane) (L); Trắc mũi giáo, Bạt ong (V).

Deciduous trees 15-30 m high, 60-100 cm diameter. Trunk straight. Young branchlets spreading, ferruginous tomentose, later glabrous. Bark smooth, black. Stipules ovate, slightly falcate, $12-15 \mathrm{~mm}$ long, caducous. Petioles $1.5-2.5 \mathrm{~cm}$ long. Leaves $10-20 \mathrm{~cm}$ long, rhachises $7-15 \mathrm{~cm}$ long. Petiolules $2-3 \mathrm{~mm}$ long. Leaflets alternate or subopposite, 7-13, rarely 15 , lateral leaflets ovate, elliptic, terminal ones elliptic or obovate, $2.5-6.5$ by $1.5-3 \mathrm{~cm}$, apex rounded, emarginate, base rounded, obtuse, both surfaces glabrous or glabrescent, secondary veins 9-12 pairs, smaller veins reticulate, both surfaces easily visible, at first densely tomentose, later glabrous. Inflorescences axillary or terminal panicle, $5-10 \mathrm{~cm}$ long, appearing before leaves. Peduncles slender, $2-5 \mathrm{~cm}$ long, hairy. Bracts and bracteoles very small, caducous. Flowers greenish, 9-10 mm long. Pedicels $2 \mathrm{~mm}$ long, hairy. Calyx tube, 4-6 mm long, hairy, upper teeth ovate, $1-1.5 \mathrm{~mm}$ long, obtuse, hairy. Standard rounded, slightly emarginated at apex, $6-8$ by $6-8 \mathrm{~mm}$ (incl. claw c. $2 \mathrm{~mm}$ long), callosities present at base. Wings spoon-shaped, 6 by $4 \mathrm{~mm}$ (incl. claw 1.5-2 mm long). Keel petals machete-shaped, 4 by $3.5 \mathrm{~mm}$ (incl. claw $1.8 \mathrm{~mm}$ long). Stamens $10,4-6 \mathrm{~mm}$ long, diadelphous $(5+5)$. Ovary $3-5 \mathrm{~mm}$ long, hairy along the margin and all at base toward stalk, style $2 \mathrm{~mm}$ long, glabrous, ovules 3 or 4 , stalk $2 \mathrm{~mm}$ long, hairy. Fruit a pod, $6-11$ by $1.5 \mathrm{~cm}$, flat, 
bulging over the seeds, fruit-stalk 1-1.5 cm long. Seed $(s) 1-3$, reniform or bean-shaped, 6-7 by $4-5 \mathrm{~mm}$ in the central part, dark brown or black.

Distribution - Sri Lanka, India, Myanmar, Indochina, Thailand. In Laos: Louang Prabang (Phou Kouay), Vientiane (Ban Pha Khao), and Savannakhet (Savannakhet - Thakhak) provinces. In Vietnam: Hà Nôi, Hà Bac, Dac Lac, and Lâm Dông provinces.

Habitat \& Ecology - Usually in mixed deciduous forest, evergreen and open forest, along streams, altitude up to $1500 \mathrm{~m}$. Seedling develop well under the tree canopy, when mature they become light demanding. Natural regeneration medium. Flowering: March to June; fruiting: June to December.

Uses - Wood used for tool-handles, boats, rafters, scantlings, packaging, and other general purposes. Bark contains $14 \%$ tannin, used in medicine.

Specimens examined: Balansa 4996 (P); Chevalier 40299 (P); Schmid 747 (P); Tixier s.n. (P); Vidal 1437, 1775, 2601 (P).

\section{Dalbergia oliveri Prain - Fig. 39}

Synonyms - Dalbergia bariensis Pierre; D. dongnaiensis Pierre; D. duperreana Pierre; D. mammosa Pierre

Vernacular names - Kham phi leung (Vientiane), Padong deng (Savannakhet) (L); Cầm lai, Cầm lai bong, Cầm lai mât (South), Trắc lai (Ninh Thuân) (V).

Deciduous trees 15-30 m high, 60-90 cm diam., crown spreading when mature. Bark grey, rather thick, scaly, flaking in small pieces, inner bark yellow, heartwood dark red. Branches stout, slightly pubescent. Stipules early caducous. Leaves $15-25 \mathrm{~cm}$ long, petioles 3-5 cm long, rhachises 10-18 cm long. Petiolules 3-4 mm long. Leaflets alternate, $13-17$, rarely $9-11$ or $19-21$, ovate, $4-8$ by $1.2-3 \mathrm{~cm}$, lateral and terminal leaflets similar in shape and size, apex obtuse or acuminate, often mucronate at the top, base rounded, both surfaces glabrous, secondary veins 9-12 pairs, both surfaces reticulate; young leaves pale pink with silky hairs, mature leaves dark grey-green, glabrous. Inflorescences axillary or terminal panicle, $10-45 \mathrm{~cm}$ long. Peduncle 8-10 $\mathrm{cm}$ long, slightly pubescent. Bracts early caducous. Bracteoles ovate, 1.2 by $0.3 \mathrm{~mm}$, hairy, caducous. Flowers purple in bud, pale purple or white, in branched clusters at end of twigs, 10-12 mm long. Pedicels $1.5 \mathrm{~mm}$ long, slightly pubescent. Calyx tube, 4-5.5 mm long, glabrous at the base, teeth hairy, the longest tooth ovate-elliptic, $3 \mathrm{~mm}$ long, lateral teeth ovate, 2 by $1.2 \mathrm{~mm}$, upper teeth triangular, 1.2 by $2 \mathrm{~mm}$. Standard rounded or orbicular, $6-7$ by $6-7 \mathrm{~mm}$ (incl. claw $1.5-2 \mathrm{~mm}$ long), callosities present, apex rounded. Wings spoon-shaped, curved toward apex, 6-7.5 by $3.5-4 \mathrm{~mm}$ (incl. claw $1.5-2 \mathrm{~mm}$ long). Keel petals ear-shaped, $4-6$ by $2.5-3.5 \mathrm{~mm}$ (incl. claw $1.5-2$ $\mathrm{mm}$ long). Stamens 10 , diadelphous $(5+5), 6-8 \mathrm{~mm}$ long. Ovary 3-4 mm long, hairy along the margin at the lower part, ovules 2 or 3 , style $2-3 \mathrm{~mm}$ long, glabrous, stalk 2-3 mm long, hairy. Pods elliptic, $10-12$ by $2.5-4.5 \mathrm{~cm}$, flat, bulging over the seeds, fruit-stalk $1-1.5 \mathrm{~cm}$ long. Seed(s) usually 1 , sometimes 2 or 3 , reniform or bean-shaped, 12.5 by $9 \mathrm{~mm}$, in the central part, flattened, brown or reddish.

Distribution - Myanmar, Indochina, Thailand. In Laos: Savannakhet and Saravane provinces. In Vietnam: Quang Tri, Dac Lac, Lâm Dông, Phu Yên, Ninh Thuân, Binh Thuân, Dông Nai, and Bà Ria-Vung Tàu provinces. 


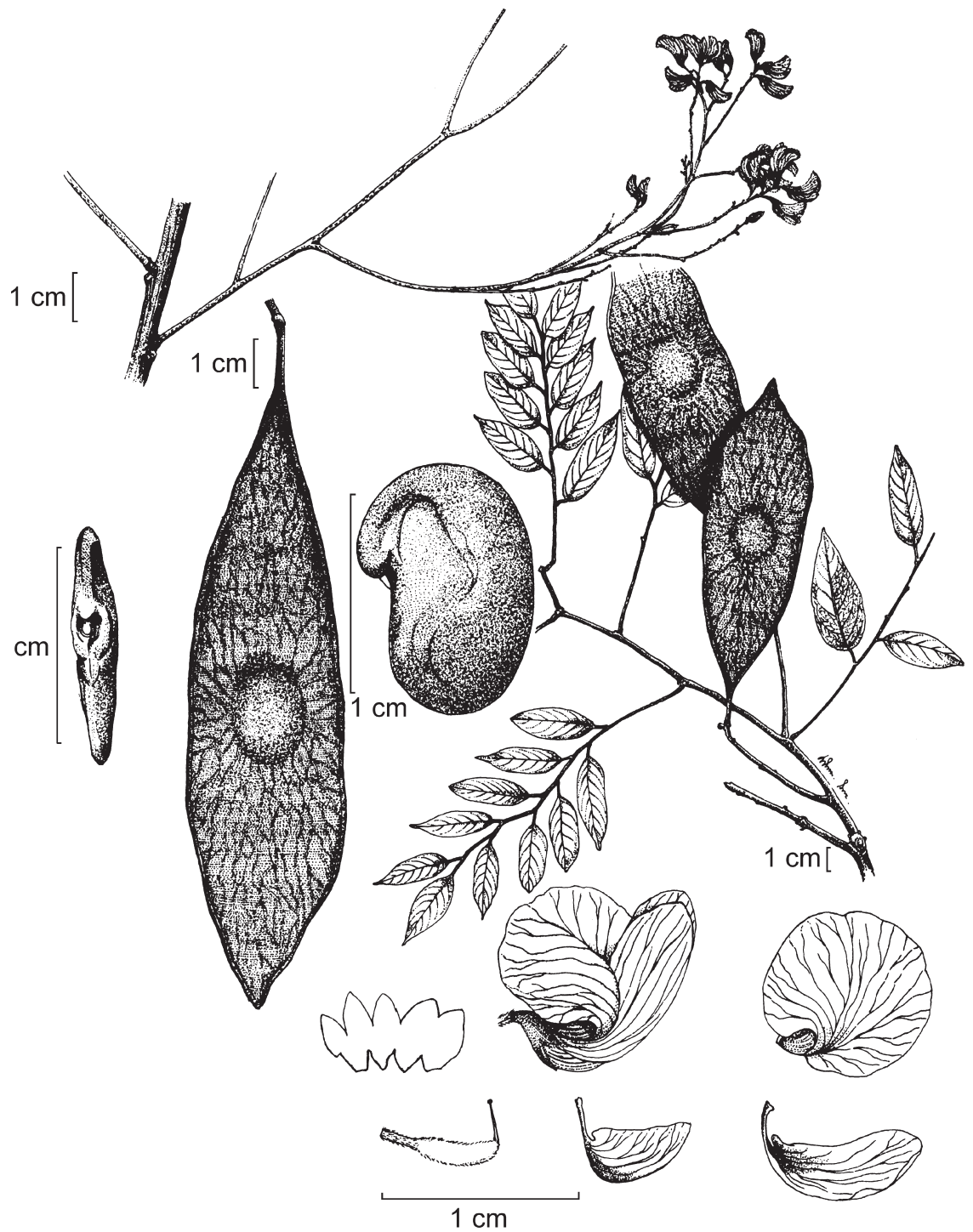

Fig. 39. Dalbergia oliveri Prain (Papilionaceae).

Habitat \& Ecology - Usually in primary and secondary forest, mixed deciduous forest, tropical evergreen or semi-deciduous forest, along streams, altitude up to $1200 \mathrm{~m}$. Usually mixed with Albizia chinensis, Dalbergia cochinchinensis, Dipterocarpus alatus, and Sindora siamensis. Flowering: February to June; fruiting: April to December.

Uses - Wood red, hard, with an attractive structure and therefore usually used for furniture and handles of agricultural implements.

Specimens examined: Chevalier 36628 (P); Pierre 1711 (P); Poilane 5632, 5844, 10058, 12059, 13745, 13747 (P); Vidal 1745 (P). 


\section{ERYTHRINA L.}

Erythrina fusca Lour. - Fig. 40

Synonym - Erythrina ovalifolia Roxb.

Vernacular names - Thong lang (L); Vông (V).

Deciduous trees up to $35 \mathrm{~m}$ high, 25-60 cm diameter. Bole gnarled; bark greyish or pale brown. Trunk and branches armed with up to $2 \mathrm{~cm}$ long spines, crown rounded. Stipules orbicular, c. $3 \mathrm{~mm}$ diam., caducous. Leaves trifoliolate, 20-30 cm long; petioles 4-10 cm long, very hairy, later glabrous. Stipellae present or absent below the terminal leaflet, gland-like, persistent and rounded. Terminal leaflets elliptic or ovate,

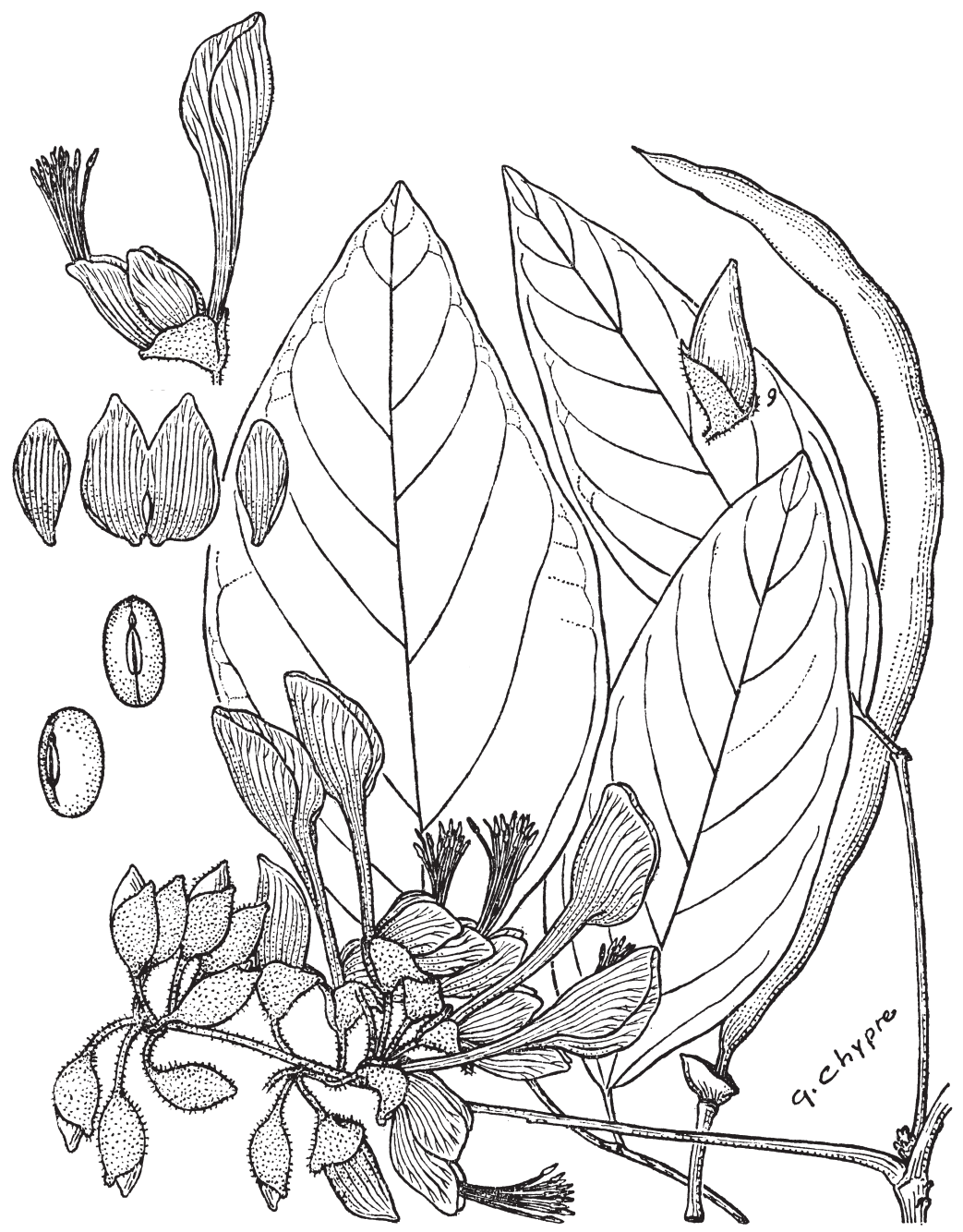

Fig. 40. Erythina fusca Lour. (Papilionaceae). 
$10-15$ by $5-8 \mathrm{~cm}$, petiolules $3-4 \mathrm{~cm}$ long, base broad rounded or obtuse, apex obtuse or almost short acuminate, secondary veins 5-9 per side; lateral ones smaller, 9-11 by $4-5 \mathrm{~cm}$, petiolules $0.4-0.5 \mathrm{~cm}$ long. Inflorescences lax racemes, $8-20$ flowers, 8-30 cm long; peduncle 5-20 cm long, densely pubescent, glabrescent. Bracts ovate, puberulous, caducous. Pedicels 5-15 mm long, puberulous. Bracteoles at apex of pedicels, ovate, $2-3$ by $1.5-2.5 \mathrm{~mm}$, outside densely pubescent, inside glabrous. Flowers $30 \mathrm{~mm}$ long. Calyx broadly bell-shaped, 12 by $15 \mathrm{~mm}$, asymmetric bilabiate, upper lip 10-14 mm long, lower lip 12-17 mm long, curved downwards, outside densely pubescent, inside glabrous. Standard orange to dark red; claw 9-21 mm long; blade cuneiform, or orbicular to transversely elliptic, $25-30$ by $30-40 \mathrm{~mm}$, apex usually emarginate, both sides glabrous. Wings creamish green, purplish at apex, claw 1-5 mm long; blade obliquely obovate, $17-35$ by $10-20 \mathrm{~mm}$, apex rounded or obtuse, both sides glabrous. Keel petals adnate, creamish green, often purple at the base or purplish veined, claw $2-3 \mathrm{~mm}$ long; blade ovate to obliquely rhomboid, $13-35$ by $7-17 \mathrm{~mm}$, both sides glabrous. Stamens 10 , diadelphous $(1+9)$, greenish white, half as long as the standard, about 30-40 mm long. Ovary 15-25 mm long, densely hairy; style 10-12 $\mathrm{mm}$ long, pubescent at the base, upwards glabrous. Pods strap-like, black, 10-20 by $1-1.5 \mathrm{~cm}$, stipe $1.5-2 \mathrm{~cm}$ long, dehiscent, outside densely pubescent, inside glabrous. Seeds usually more than 1, dark brown or black, transversely ellipsoid, 1-18 by 5-8 by $6 \mathrm{~mm}$, hilum $6-8 \mathrm{~mm}$ long.

Distribution - South America, India, Myanmar, Indochina, Thailand, throughout Malesia, Pacific Islands. In Laos: Vientiane province. In Vietnam: Lâm Dông, Binh Thuân, Ninh Thuân, and Trà Vinh provinces; planted in many cities in the north.

Habitat \& Ecology - From tropical dry to wet through subtropical dry to wet forest, secondary or swamp forest, often along coasts or on river banks, usually close to water. Flowering and fruiting probably throughout the year. In Indochina flowering: November to February; fruiting: January to April.

Uses - Planted as a hedge, as a support tree, and as ornamental shade trees, along roads, around buildings, as living fences of rice-fields and gardens, along pastures, coffee, or cacao plantation. Can be used for green manure and animal feeding. Flowers and young leaves are eaten or used to make tea, and seeds are used in folk medicine as remedies for cancer. Wood is very light and used for canoes and carving.

Specimens examined: Chevalier 30309, 30343 (P); Hiep 508 (P); Poilane 31333 (P); Thorel 699, 3005 (P); Vidal 1 (P).

\section{PTEROCARPUS Jacq.}

Small to big semi-deciduous trees up to $40 \mathrm{~m}$ high, up to $350 \mathrm{~cm}$ diam., usually there are big double leader branches which are rather close to the base, with pronounced low plank buttresses and dense wide-spreading drooping dome-shaped crown. Bark greyish brown becoming scaly and fissured with age, inner bark with red sap. Stipules small linear to triangular, caducous. Leaves compound, alternate, imparipinnate, stipels absent. Leaflets entire, alternate, sometimes subopposite or opposite. Inflorescences axillary or terminal racemes or panicles; bracts early caducous. Flowers big, bright yellow, bisexual, irregular. Pedicels articulate at bracteoles insertion. Bracteoles small, filiform, or linear to narrowly triangular, early caducous. Calyx bell-shaped-tubular, 
often slightly incurved at the base, 5-lobed, subequal or unequal, upper 2 teeth usually bigger, lower 3 teeth smaller and more or less deeply or rather widely lobed. Petals exserted, with long claws. Standard orbicular with a well-developed claw. Wings free, more or less obovate to sometimes spatulate. Keel petals shorter and smaller. Stamens 10 , monodelphous or diadelphous (5+5). Ovary sessile or stalked, ovules 2-4, hairy; style filiform, glabrous. Pods flattened, disc-like, more or less rounded or orbicular, sometimes falcate or plainly asymmetrical, winged, seed-bearing portion corky, hairy or glabrous, indehiscent. Seed $(s)$ usually 1, sometimes 3 or 4 .

Distribution - In all tropical countries of the world: 60-70 species. Almost pantropic, from southern Myanmar through Southeast Asia towards the Santa Cruz and Pacific Islands. Cultivated in Africa, Sri Lanka, India, Taiwan, Okinawa, Hawaii, and Central America. In Laos: 1 species. In Vietnam: 2 species.

\section{KEY TO THE SPECIES}

1a. Leaflets ovate to broad elliptic, $4-15$ by $2-9 \mathrm{~cm}$; apex acuminate, acumen emarginate, short apiculate; secondary veins 8-10 pairs. Inflorescences axillary or terminal panicles. Fruit wing smooth, style point (beak) in upper half .... 1.P. indicus

b. Leaflets narrowly elliptic, $3-9$ by $2-4 \mathrm{~cm}$; apex acute or acuminate, acumen not emarginate, long apiculate; secondary veins 11-17 pairs. Inflorescences axillary racemes. Fruits wing wavy, style point (beak) in lower half . 2. P. macrocarpus

\section{Pterocarpus indicus Willd. - Fig. 41}

Synonyms - Lingoum indicum (Willd.) Kuntze; L. wallichii (Wight \& Arn.) Pierre; Pterocarpus pallidus Blanco; P. wallichii Wight \& Arn.; P. zollingeri Miq.

Vernacular names - Chan daeng, Du bai yai (L); Giáng hưong (V), Gioc (Kien Gian), Huỷnh bà rù̀ng (Kiên Giang).

Large, deciduous trees c. $40 \mathrm{~m}$ high, up to $350 \mathrm{~cm}$ diam., with large and high buttresses, in open areas usually with a wide-spreading to dome-like and large crown, lower branches drooping and sometimes touching the ground. Bark greyish brown, shallowly fissured, often thin-scaly and peeling off irregularly. Branchlets light brown to dark brown, sparsely to densely lenticellate or sometimes not at all, young parts dark brown to blackish, hairy, glabrescent. Stipules linear, $7-15 \mathrm{~mm}$ long, hairy on both sides, caducous. Leaves $12-25 \mathrm{~cm}$ long, petiole $2-4 \mathrm{~cm}$ long, usually hairy, rhachis 6-18 $\mathrm{cm}$ long, sparsely hairy, glabrescent. Leaflets $5-11$, ovate to widely elliptic, $4-15$ by 2-9 cm; chartaceous to subcoriaceous, base generally rounded or sometimes obtuse to acute, apex usually acuminate, sometimes acute, rarely obtuse, acumen emarginate, short apiculate, surfaces concolorous, greyish brown, sometimes greenish, above slightly shiny, glabrous, beneath slightly dull, sparsely hairy, glabrescent, secondary veins 8-10 pairs; petiolules 3-5 mm long. Inflorescences laxly branched, axillary or terminal panicles, $10-20 \mathrm{~cm}$ long. Bracts and bracteoles filiform, 3-6 mm long, often early caducous. Flowers bright yellow. Pedicels $6-11 \mathrm{~mm}$ long, pubescent. Calyx 5-6 $\mathrm{mm}$ long, glabrous or sparsely hairy, all the lobes inside sparsely hairy towards the top. Standard orbicular, $10-15 \mathrm{~mm}$ wide, claw $4.5-6 \mathrm{~mm}$ long. Wings $10-15$ by $5-7$ $\mathrm{mm}$, claw $4.5 \mathrm{~mm}$ long. Keel petals $6-9$ by $3-4 \mathrm{~mm}$, claw $4.5 \mathrm{~mm}$ long. Stamens 10 , 


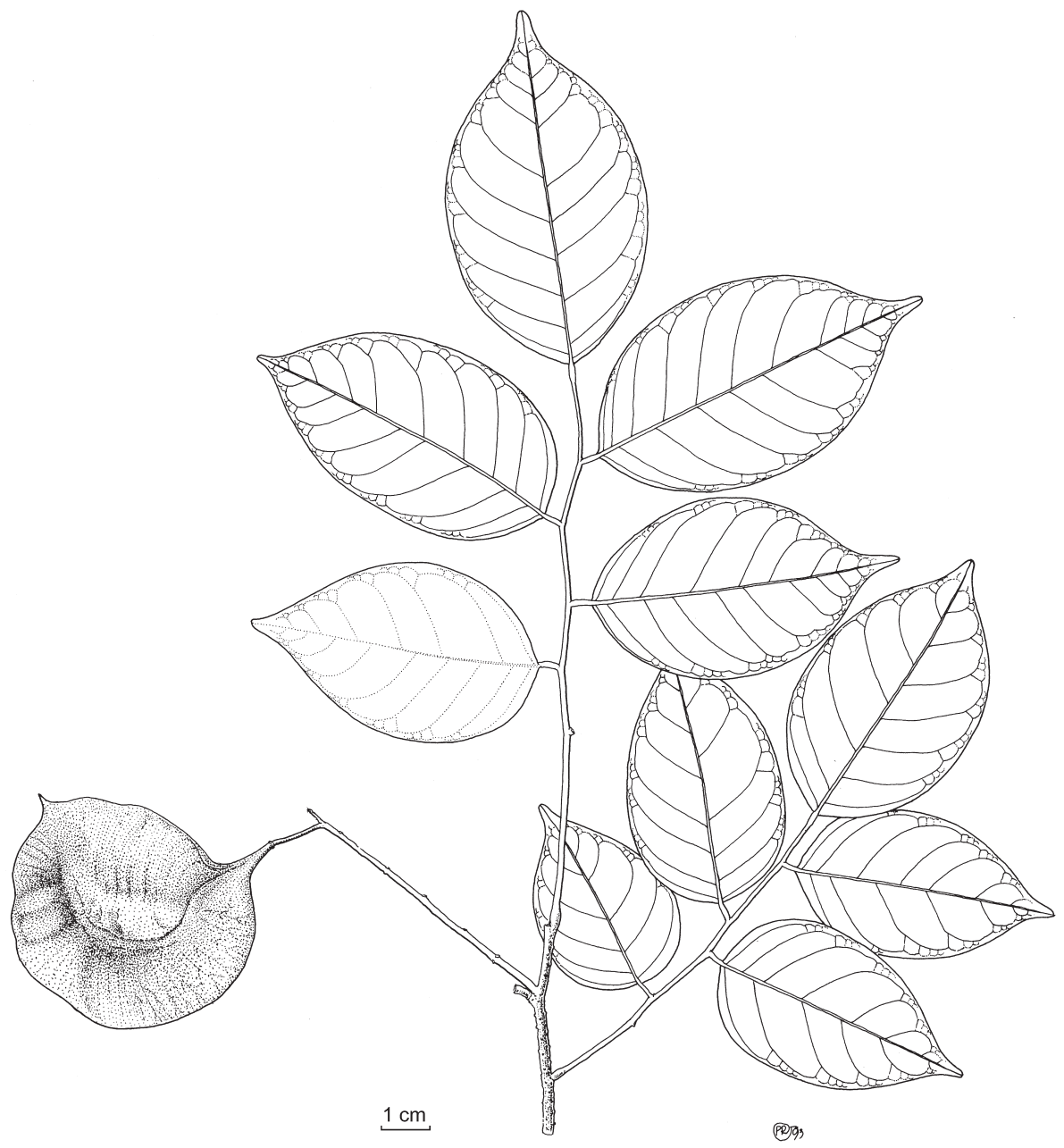

Fig. 41. Pterocarpus indicus Willd. (Papilionaceae).

diadelphous. Ovary densely hairy, style 4-5 mm long, 2 or 3 ovules. Fruit orbicular or semi-orbicular, 4-6.6 cm diam., brown to blackish, densely hairy, wing smooth, style point (beak) in upper half, stalk 5-9 mm long, seed-bearing part $1.5-3 \mathrm{~cm}$ diam., thickened, 6-9 mm thick, more or less woody. Seed(s) 1 or 2, widest at or below the hilum, $2-5$ by $8-10 \mathrm{~mm}$; testa dark brown, smooth.

Distribution - India, Myanmar, Indochina, Thailand, farther eastward reaching the Solomons (eastern limit) in the Pacific via Sumatra, West Java, Borneo, Philippines, Sunda Islands, Moluccas, New Guinea, the Pacific (Ryukyu, Carolines). In Laos: unknown. In Vietnam: Kiên Giang, Hô Chi Minh, and Thua Thiên-Huê provinces.

Habitat \& Ecology - Rain forest or evergreen forest, also in dry areas, in the lowlands, altitude up to $600 \mathrm{~m}$. Seems to prefer a seasonal climate. Flowering: February to May; fruiting: December. 
Uses - Wood is used for cabinetry, cart wheels, carving, construction, furniture, and musical instruments. Planted occasionally as shade and ornamental tree. The young leaves and flowers are edible. The flowers are a honey source. The leaves are used as shampoo. The beautiful, termite resistant, rose-scented timber is marketed. The wood gives a reddish dye. Leaves and bark used as anti-emetic, folk remedy for bladder ailments, diarrhoea, dropsy, headache, sores, stones, thrush, and tumours of the abdomen.

Note - Vidal (1959) mentions this species occurring in Laos, although all other literature does not list it.

Specimens examined: Chevalier 31397,31410, 38287 (P); Edouard 337, 2709 (P); Fleury 30088 (P); Kerr 15809 (P); Put 2222 (P); Zimmermann 39 (P).

\section{Pterocarpus macrocarpus Kurz}

Synonyms - Lingoum cambodianum Pierre; L. macrocarpum (Kurz) Kuntze; Pterocarpus cambodianus (Pierre) Gagnep.; P. cambodianus var. glaucinus (Pierre) Gagnep.; P. cambodianus var. gracilis (Pierre) Gagnep.; P. cambodianus var. parviflorus (Pierre) Gagnep.; P. macrocarpus Kurz var. oblongus (Pierre) Gagnep.

Vernacular names - Mai du (general), Du luad (Sayabouri) (L); Dáng hương, Sông la (Quang Tri) (V).

Large, deciduous trees c. $30 \mathrm{~m}$ high, up to $300 \mathrm{~cm}$ diam., with large and high buttresses, in open areas usually with a wide-spreading to dome-shaped crown, large and spreading branches, drooping and sometimes touching the ground. Bark pale brown or grey, thickened, slightly fissured, becoming darker or blackish and scaly with age; inner bark fibrous, red-brown with sparse drops of red sap. Stipules linear, 7-15 mm long, hairy on both sides, caducous. Leaves $8-20 \mathrm{~cm}$ long, petiole 3-5 cm long, usually short hairy, rhachis 5-15 cm long, densely hairy, glabrescent. Leaflets 7-13, alternate or rarely subopposite, narrowly elliptic, $3-9$ by $2-4 \mathrm{~cm}$, base rounded or obtuse, apex acute or acuminate-obtuse, acumen not emarginate, long apiculate, young leaves densely hairy, mature leaves bright or dark green and smooth above, usually dull green with scattered brown hairs on veins below, secondary veins 11-17 pairs; petiolules 4-5 mm long, with scattered brown hairs. Inflorescences usually axillary racemes, $10-15 \mathrm{~cm}$ long. Bracts early caducous. Bracteoles linear, 2-3 by $1 \mathrm{~mm}$, caducous. Pedicels $10 \mathrm{~mm}$ long, pubescent. Flowers bright yellow. Calyx bell-shaped, 5-6 $\mathrm{mm}$ long, hairy, all the lobes hairy on both sides towards the top. Standard obovate-elliptic, 11-13 by 9-12 $\mathrm{mm}$, claw 4-5 mm long. Wings falcate, obovate, auriculate, $10-15$ by $5-7 \mathrm{~mm}$, claw 4-5 mm long. Keel petals auriculate, $9-10$ by $4-5 \mathrm{~mm}$, claw 3-5 mm long. Stamens 10, monodelphous or diadelphous, unequal. Ovary superior, 3-5 $\mathrm{mm}$ long, densely brownish hairy, ovules 2 or 3, style $3-5 \mathrm{~mm}$ long, glabrous towards the top, stalk 1-2 $\mathrm{mm}$ long, glabrous at the base. Fruits orbicular or semi-orbicular, 4-6 cm diam., wing wavy, style point (beak) in lower half, densely with pale brown or whitish hairs when young, later glabrescent, seed-bearing part 1.5-3 cm diam., thickened, 6-10 mm thick, more or less woody, margin between the beak and stalk usually concave, rarely straight, stalk 5-10 mm long. Seed(s) 1 or 2, $9 \mathrm{~mm}$ long, testa brown, smooth.

Distribution - Myanmar, Indochina, Thailand. In Laos: Sayabouri (Phou Sak, Paklay), Louang Prabang (Phou Khouang), Vientiane (Tha Ngon, Hatxiafong, Ban Khuay Daeng), Bolikhamsai (Borikhane Distr.), Savannakhet, and Saravane provinces. 
In Vietnam: Hà Nôi, Nghê An, Quang Tri, Dac Lac, Khanh Hoa, Ninh Hoa, Ninh Thuân, Sông Bé, Tây Ninh, Dông Nai, Hô Chi Minh, and Kiên Giang provinces.

Habitat \& Ecology - Occurring in open semi-deciduous or deciduous Dipterocarp forest, on well-drained, light-textured soils, but with shallow depth and poor in humus. Natural stands especially in dry and hot habitats. Light demanding and drought tolerant tree, often mixed with Afzelia xylocarpa, Bambusa spp., Dalbergia spp., Dendrocalamus spp., Lagerstroemia calyculata, Peltophorum dasyrhachis, Pentacme spp., Schima crenata, Shorea spp., Sterculia spp., Terminalia spp., and Vitex species. Flowering: January to May; fruiting: April to December.

Uses - The reddish hard wood has a beautiful appearance, is resistant to termites and insects, classified as a first class timber in Laos and Vietnam. Used in construction and for cabinetry, cart wheels, carving, construction, furniture, and musical instruments. Resin can be used as a red dye. Bark and root used for indigenous medicine, folk remedy for bladder ailments, diarrhoea.

Specimens examined: Chevalier 2, 12, 31362, 37742, 39160, 39207, 39938, 40570 (P), 30070 (L, P); Evrard 845 (P); Godefroy 238 (L); Hiep 158, 391, 995 (P); Kerr 20754 (P); Lecomte 2010 (P); Maxwell 99-235 (L); Muller 190, 245 (P); Phung Van Dien 126 (P); Pierre 125, 1817, 6545 (P), 6544 (L, P); Poilane 1327, 2433, 4979, 8472, 11775, 12383, 13710, 13715, 13769, 13775, 14133, 16357, 17879, 27988, 30477, 32425 (P), 13339 (L, P); Soejarto 10724 (L); Spire 864 (P); Vidal 1305, 2073, 2355, $2613(\mathrm{P})$.

\section{ROSACEAE}

Trees, shrubs, herbs, or climbers. Stipules on the twig or on the base of the petiole, free or adnate to the petiole, rarely absent. Leaves simple or compound, usually alternate or spirally arranged, rarely opposite. Inflorescences various. Flowers usually bisexual and regular. Hypanthium (calyx tube) usually very distinct, from saucer-shaped to tubular or bell-shaped, sepals, petals, and stamens inserted on its rim. Sepals usually 5, free, overlapping. Petals usually 5, free, overlapping, large or small, showy or not. Stamens 5 to many, free, filaments slender, anther 2-locular, splitting longitudinally. Ovary superior or inferior, styles free, free or connate at terminal, lateral or basal. Fruits various, flesh or dry, splitting or not.Seed(s) 1 to many, with or without endosperm.

Distribution - Worldwide: c. 100 genera, c. 3000 species. In Laos: c. 18 genera, c. 44 species. In Vietnam: c. 20 genera, 113 species.

\section{PYRUS L.}

Pyrus pashia D. Don - Fig. 42

Synonyms - Pyrus kumaoni Decne.; P. variolosa Wall.; P. verruculosa Bertol.

Vernacular names - Mak chong, Mak chong pa (L); San tan ngai (Lai Châu prov.) (V).

Small to medium deciduous trees or shrubs, with spiny trunk and branches. Stipules filiform or linear, caducous. Petioles $1-4 \mathrm{~cm}$ long. Leaves ovate, $5-10$ by $2-4 \mathrm{~cm}$, base rounded, margin dentate, apex acuminate, secondary veins 7-10 pairs. Inflorescences axillary, umbel-like. Flowers white, 6-12. Pedicel hairy or glabrous, 2-3 cm long. Sepals hairy, lobed, triangular, acute. Petals 8 by $6 \mathrm{~mm}$. Stamens many. Ovary inferior, 


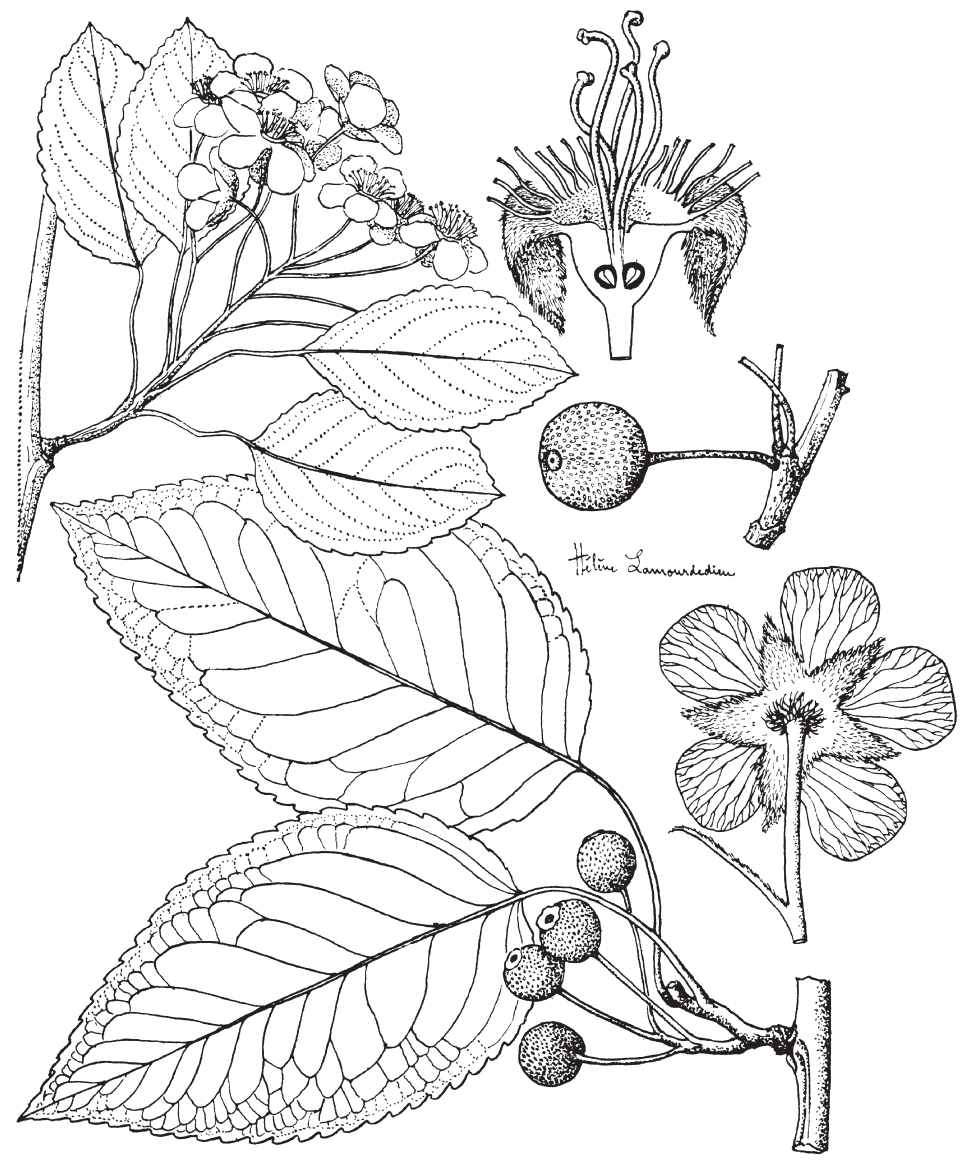

Fig. 42. Pyrus pashia D. Don (Rosaceae).

$3-5 \mathrm{~mm}$ long, style 2-5 mm long, glabrous or hairy at the base. Fruit globose, 1-2 $\mathrm{cm}$ diameter.

Distribution - Nepal, China (Himalaya), Indochina. In Laos: Houa Phan, Xieng Khouang, Saravane, and Champassak (Bolaven plateau) provinces. In Vietnam: Lai Châu, Cao Bang, and Lang Son provinces.

Habitat \& Ecology - Occurring on moist sandy, loamy and yellow red clay, near small streams or swamp areas, but also at the lower forest edge near rice paddy fields and open shrub land. Flowering: December to January; fruiting: February to April, and fully ripe from September to December.

Uses - Wood can be used as fuel. Fruits are edible. Young shoots, leaves, and flowers are eaten as vegetables.

Specimens examined: Balansa 1535 (P); Chevalier 16, 29735 (P); Eberhardt 5072 (P); Mievilles 4, 5, 6, 7, 1921, 40910, 41062 (P); Pételot 6166 (P); Poilane 1920, 1964, 2042, 2043, 2051, 2128 , 2134, 2136, 2200, 15904, 16198, 16262, 19066, 20026, 20066, 25660, 28397, 41142, 41144, 41145, 41146, 41193, 41264 (P); Spire 465, 1414 (P); Vidal 17, 868, 1477 (P). 


\section{SAPINDACEAE}

Trees, shrubs, or lianas, rarely climbing herbs. Bark usually smooth, inner bark without sap except for Pometia. Leaves spirally arranged, rarely opposite or whorled, simple, pinnate, digitate, or bipinnate. True stipules usually absent, pseudo-stipules sometimes present. Leaflets opposite to alternate, entire or dentate. Inflorescences axillary or terminal, spike-like to panicles. Bracts and bracteoles present. Flowers usually unisexual, rarely bisexual. Sepals 4 or 5 , rarely more, free to united. Petals absent or $2-6$, free. Disc present. Stamens $5-10$, rarely more, usually 8 , always inserted within the disc, filaments glabrous or hairy, anthers basifixed. Ovary superior 1-3(-8)-locular, lobed or not, ovule(s) 1 or 2 per locule. Fruit capsules, drupes, sometimes with fleshy sarcotesta or aril, pericarp smooth, muricate or with spines or hairs. Seeds completely or partially covered by the sarcotesta or aril.

Distribution - Throughout the tropical and subtropical regions of the world, especially well represented in South America: c. 140 genera, c. 1350 species. In Laos and Vietnam: c. 23 genera, c. 63 species.

\section{SAPINDUS L.}

\section{Sapindus saponaria L.}

Synonyms - Sapindus microcarpus Jard.; S. mukorossi Gaertn.; S. vitiensis A. Gray

Vernacular names - Kho sak, Sak (L); Bồ hòn (V).

Trees up to $25 \mathrm{~m}$ high, $60 \mathrm{~cm}$ diameter. Trunk straight and cylindrical. Bark smooth, greenish grey, or greyish brown. Young branchlets terete, yellowish grey hairy, glabrescent, with dense, small lenticels and obcordate leaves scars. Leaves usually spirally arranged at the tip of the twigs, paripinnate, up to $40 \mathrm{~cm}$ long. Petioles terete to 3 angular in cross section, $1.5-6 \mathrm{~cm}$ long. Leaflets 3-5 pairs, subopposite, elliptic, 6-16 by $3-6 \mathrm{~cm}$, base cuneate, oblique, margin entire, apex obtuse to acute, glabrous on both surfaces, shiny above, lateral veins $8-15$ pairs, slightly curved to nearly straight, prominent on both surfaces. Inflorescences terminal panicles, up to $30 \mathrm{~cm}$ long, pubescent. Flowers bisexual, cream-coloured. Sepals 5, hairy outside or nearly glabrous, ciliate at the margin. Petals 5, greenish white, lanceolate, woolly-ciliate. Disc annular, glabrous. Stamens 8 , free, exerted, filaments hairy at base. Ovary ovoid, 3-locular, 1 ovule per locule. Fruit a globose drupe, $2-3 \mathrm{~cm}$ diam., base often with vestiges of 2 aborted carpels, yellowish when mature. Seeds globose, dark brown, 1-1.5 cm diam., hilum 5-6 mm long.

Distribution - India, Myanmar, China, Taiwan, Japan, Korea, Indochina, Thailand, Malesia. In Laos: Houa Phan, Louang Prabang, and Xieng Khouang provinces. In Vietnam: in many provinces, such as Cao Bang, Lang Son, Bac Thai, Ninh Binh, Thanh Hoa, and Nghê An.

Habitat \& Ecology - Primary and secondary forest, altitude below $1000 \mathrm{~m}$. Usually distributed around villages or in secondary forests. Preferring deep, fertile, and wet soils. Fast-growing tree. Natural regeneration is good. Flowering: April, May; fruiting: September to November. 
Uses - Sapwood yellowish white, heartwood yellowish grey. Used for making furniture, sawing board, plywood, and boards. The drupes, which lather when combined with water, were once used in varnish, floor wash, and soap. In some areas this species is still preferred for washing hair and delicate clothing, even after the introduction of commercial soaps.

Specimens examined: Averyanov et al. VH 1513 (P); Bon 1561 (P); Chevalier 38577, 40982 (L); Eberhardt 3274 (P); Fleury 37769, 37902, 38006 (L); Gilbert 37832 (L); Hiep 5 (L); Poilane 2045 (L); Tsang 29829 (P).

\section{SAPOTACEAE}

Trees or shrubs, monoecious or dioecious, with white, rarely yellow latex. Bark usually brown, cracked or fissured, inner bark usually soft, fibrous, pink or red. Twigs often scurfy when young. Stipules paired, generally triangular or ovate and usually soon falling or absent. Leaves simple, spirally arranged and frequently crowded at the end of twigs, or alternate and distichous, margin usually entire, venation pinnate. Inflorescences fasciculate, rarely solitary, in axils of leaves or leaf scars. Flowers bisexual, rarely unisexual, regular. Sepals in two whorls $2-5$ in a spiral, free. Corolla tubular at base, 4-16-lobed, each lobe entire or divided into 3 segments, white, pale yellow or pale green. Stamens either of the same number as corolla lobes and opposite them or numerous and arranged in 1-3 whorls, inserted at the base or at the throat or corolla tube; staminodes if present alternating with stamens or fixed in the sinuses of corolla lobes. Ovary superior, sessile, small, ovoid, 3-18-celled, each cell with 1 ovule attached to the axis, style simple, stigma small and indistinct, simple or minutely lobed. Fruit a fresh berry, rarely a drupe or capsule, with persistent sepals at the base and a persistent style at the apex. Seed(s) 1-6, ovoid to ellipsoid, glossy, brown to black outside, hard, scar usually white, large, adaxial, basiventral or basal, elongate, endosperm present or absent.

Distribution - Throughout tropical and subtropical regions: c. 53 genera, 1100 species. In Laos: c. 5 genera, 8 species. In Vietnam: c. 13 genera, c. 36 species.

\section{KEY TO THE GENERA}

1a. Bark not fissured into squares, usually with many greyish yellow dots. Leaves alternate, lateral veins slightly curved near the margin. Calyx 5-lobed. Corolla

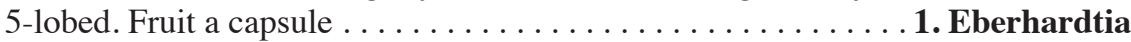

b. Bark usually fissured into squares. Leaves spirally arranged, crowed at the end of twigs, lateral veins diminishing and becoming inconspicuous towards leaf margin. Sepals 4, in two pairs. Corolla $8-12$-lobed. Fruit a berry . . . . . . 2. Madhuca

\section{EBERHARDTIA Lecomte}

\section{Eberhardtia tonkinensis Lecomte - Fig. 43}

Vernacular names - Mắc niễng, Cồng sưa bắc bộ $(\mathrm{V})$.

Trees up to $20 \mathrm{~m}$ high, up to $60 \mathrm{~cm}$ diameter. Trunk straight, cylindrical. Bark greyish brown, with many greyish yellow dots, inner bark pink with milky sap. Twigs rusty 


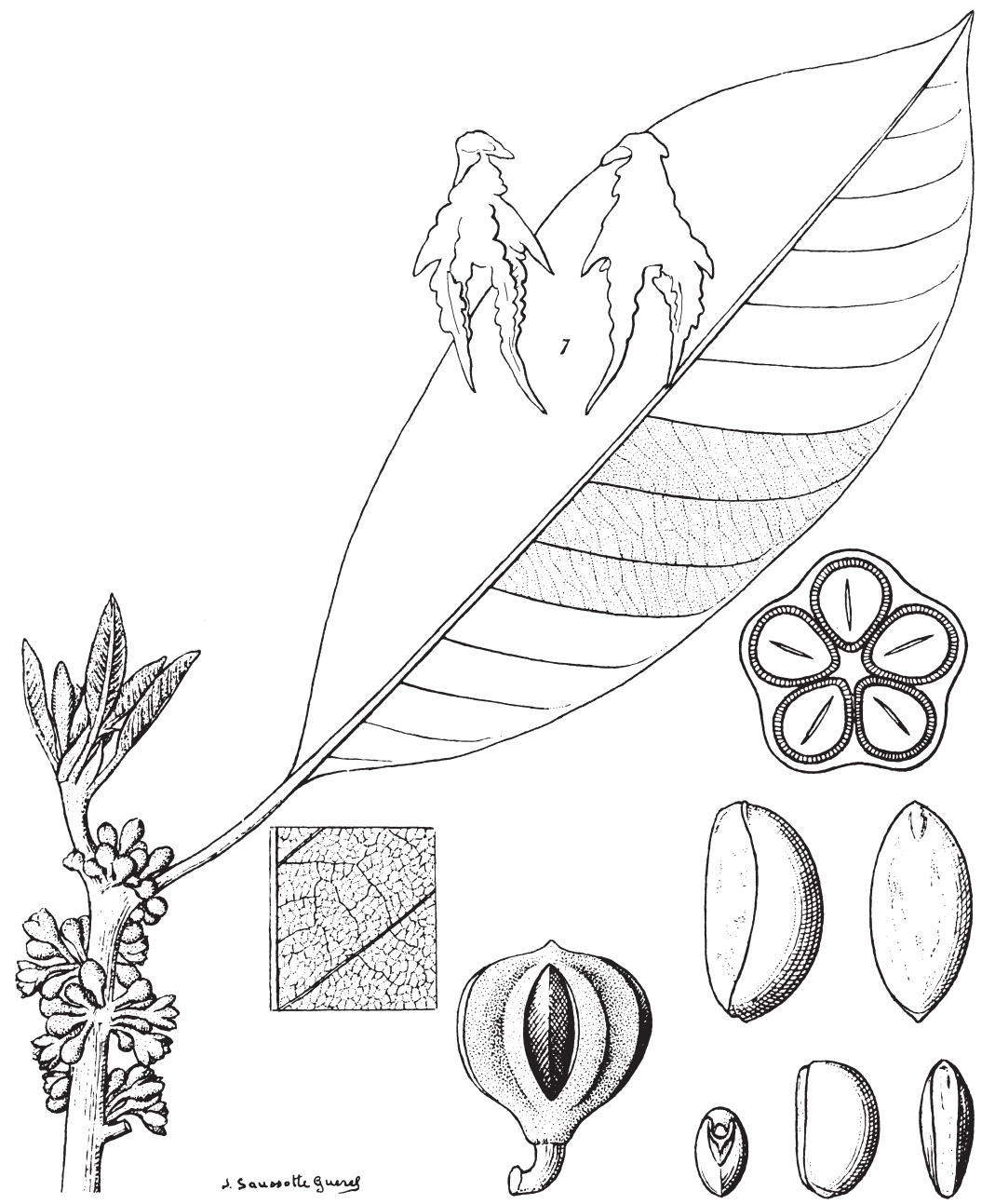

Fig. 43. Eberhardtia tonkinensis Lecomte (Sapotaceae).

tomentose. Stipules 2 , triangular. Leaves simple, alternate, elliptic, $10-30$ by $3-8 \mathrm{~cm}$, base cuneate, apex with a short point or acuminate, glabrous, green above, densely covered with silvery brown or rusty pubescence beneath, venation pinnate, the lateral veins slightly curved near the margin, prominent beneath. Petioles $1.5-3.5 \mathrm{~cm}$ long. Flowers in axillary clusters. Calyx 5-lobed, brownish hairy outside, glabrous inside. Corolla tubular, 5-lobed. Stamens 5, inserted on the throat of the corolla. Ovary ovoid, 5-celled, glabrous. Fruit a capsule, ovoid, 3-4 by $2.5-3.5 \mathrm{~cm}$, dehiscent. Seed 2-3 $\mathrm{cm}$ long, brown and shiny, glabrous, scar adaxial, oblong.

Distribution - Indochina. In Laos: Xieng Khouang province. In Vietnam: Lào Cai, Yên Bai, Lai Châu, Hà Giang, Tuyên Quang, Hoa Binh, Quang Ninh, Vinh Phu, Thanh Hoa, Ninh Binh, Nghê An, and Hà Tinh provinces. 
Habitat \& Ecology - Primary and secondary forest, altitude below $1000 \mathrm{~m}$, but mainly 500-800 m. Usually mixed with Canarium album, Castanopsis spp., Garcinia oblongifolia, Gironniera subaequalis, Quercus spp., and Schima wallichii. Fast growing and light demanding tree, but shade tolerant when young. Natural and coppice regeneration are good under a forest cover of 40-60\%. Flowering: April, May; fruiting: August, September.

Uses - Wood yellowish white, grain fine, resistant to termites. Wood used for construction and making furniture. The oil from the seeds is used for cooking.

Note - Dung (1996) recorded Eberhardtia tonkinensis to be endemic in the north of Vietnam. Examining material in Paris, however, revealed that Kerr also collected this species in Xieng Khouang province, Laos.

Specimens examined: Hance 5027 (P); Kerr 21148 (P); Pételot s.n. (P); Poilane 2025, 13125, $18807,18809(\mathrm{P})$.

\section{MADHUCA J.F. Gmel.}

\section{Madhuca pasquieri (Dubard) H.J. Lam}

Synonyms - Bassia pasquieri Lecomte; Dasillipe pasquieri Dubard

Vernacular names - Sến, Sến mật (V).

Large trees up to $40 \mathrm{~m}$ high, up to $120 \mathrm{~cm}$ diameter. Trunk straight, cylindrical. Bark blackish brown, fissured into squares, inner bark pink with milky sap. Stipules caducous. Leaves simple, spirally crowed at the end of twigs, obovate, $6-16$ by $3-6 \mathrm{~cm}$, base cuneate, apex with a short point or acuminate, glabrous, green above, pale green beneath, venation pinnate, the lateral veins diminishing and becoming inconspicuous towards leaf margin. Young leaves pink to red. Petioles $1-3 \mathrm{~cm}$ long. Flowers solitary or in axillary clusters, bisexual, yellowish white. Sepals 4, in two pairs, outer thick, inner thinner, densely hairy. Corolla tubular 8-12-lobed, imbricate. Stamens 12-22, in two whorls; staminodes absent. Ovary ovoid, densely hairy, 6-8-locular. Fruit a berry, ovoid or subglobose, 2.5-3 cm long. Seeds elliptic, 2-2.4 cm long, scar adaxial, elliptic.

Distribution - Endemic to Vietnam, in many provinces in the north, such as Lào Cai, Yên Bai, Lai Châu, Hà Giang, Tuyên Quang, Hoa Binh, Hà Bac, Bac Giang, Quang Ninh, Vinh Phu, Thanh Hoa, Ninh Binh, Nghê An, and Hà Tinh.

Habitat \& Ecology — Primary and secondary forest, altitude below $1000 \mathrm{~m}$. Usually mixed with Castanopsis indica, Erythrophloeum fordii, Garcinia oblongifolia, Gironniera subaequalis, Hopea mollissima, and Vatica odorata. Slow growing and light demanding tree, but shade tolerant when young. Prefers deep and moist soils. Natural and coppice regeneration are good under a forest cover of 50-60\%. Flowering: August to October; fruiting: December to February.

Uses - Wood pinkish red, hard, heavy, grain fine, resistant to termites. Used for construction, railway sleepers, furniture, and ship-building. The oil from the seeds is used for lighting, cooking, and in the chemical industry. Leaves used to treat burns.

Specimens examined: Balansa 4336 (L); Kerr 21148 (P); Pételot s.n. (P); Poilane 2025, 13125, $18807,18809(\mathrm{P})$. 


\section{SONNERATIACEAE}

Evergreen or deciduous trees. Stipules present or absent. Leaves simple, opposite, biseriate, entire, glabrous, coriaceous. Flowers large, showy, bisexual, actinomorphic, 1-3 or more in terminal corymbs, pedicelled, rather large. Calyx 4-8, connate into a tube, leathery. Petals absent or as many as calyx-segments, in the latter case broad and wrinkled or very narrow and smooth. Stamens many, inserted on the calyx-tube, inflexed in bud, filaments filiform-subulate, anthers reniform, 2-celled. Ovary superior, sessile with a broad base, up to 10- or more-celled, ovules numerous on thick axil placentas, style 1, robust, stigma 1, head-like, entire or slightly lobed. Fruit resting on the calyx-tube, an indehiscent berry or a valvate capsule. Seeds many, small, embedded in firm pulp or not.

Distribution - Tropical or subtropical regions: 2 genera, c. 12 species. In Laos: 1 genus, 1 species. In Vietnam: 2 genera, 4 species.

DUABANGA Buch.-Ham.

Duabanga grandiflora (DC.) Walpert - Fig. 44

Synonyms - Duabanga sonneratioides Buch.-Ham.; Lagerstroemia grandiflora DC.

Vernacular names - Lin ngo (Khammouane prov.), Phay (Xieng Khouang prov.), Ten (Laung Prabang prov.) (L); Phay sừng, Phay, Bằng lằng bần $(\mathrm{V})$.

Big trees up to $40 \mathrm{~m}$ high, up to $200 \mathrm{~cm}$ diameter. Scarcely buttressed, glabrous in all parts. Young trees have whorls of horizontal branches, but in old trees the branches usually drooping, sometimes horizontal, young branchlets quadrangular. Bark pale grey, pimply, not cracked, irregularly flaking in older trees. Stipules very small. Leaves simple, opposite, ovate to ovate-elliptic, $10-27$ by 4-10 cm, base rounded or slightly heart-shaped, margin entire, apex slightly acuminate, upper surface dark green, lower surface grey-green, completely smooth even when young, secondary veins $12-18$ pairs, parallel, arched and joined at margin. Petioles 2-9 mm long, stout. Flowers nocturnal, white, showy, with offensive smell, 4-15 cm across, in heavy branched clusters (corymbs) of 20-30 flowers at the end of twigs. Calyx tube pale green, broadly cupshaped, 1.2-3 cm across, calyx lobes $4-7$, fleshy, triangular-ovate, $1.2-3$ by $0.7-1.4$ $\mathrm{cm}$, spreading. Petals 6 or 7, obovate, 4 by $3 \mathrm{~cm}$, apex rounded, very narrow at base, wrinkled and very fragile, falling in the early morning. Stamens many, slender, much longer than petals, arranged in two rows or series, anthers curved, very mobile. Ovary broadly conical, style 1, slender, stigma lobed, dark green. Fruit ovoid-globose, 2.7-4.5 by $3-4 \mathrm{~cm}$, with large star-shaped calyx at the base, green turning brown.

Distribution - India, Myanmar, South China, Indochina, Thailand, Peninsular Malaysia. In Laos: Louang Prabang, Xieng Khouang, Champassak, and Attopeu provinces. In Vietnam: Dông Nai, Nghê An, Lào Cai, Thua Thiên-Huê, Quang Tri, Kiên Giang, and Lâm Dông provinces.

Habitat \& Ecology - Deciduous tree or partially deciduous for a brief period. Light demanding and fast-growing, especially at mountain-foots and along streams and water-ways. Suitable for a cool climate and deep or stony soil. Often in disturbed moist areas, altitude up to $1200 \mathrm{~m}$, more frequent in hilly areas on the moist valley slopes. Flowering: January to June; fruiting: March to November. 


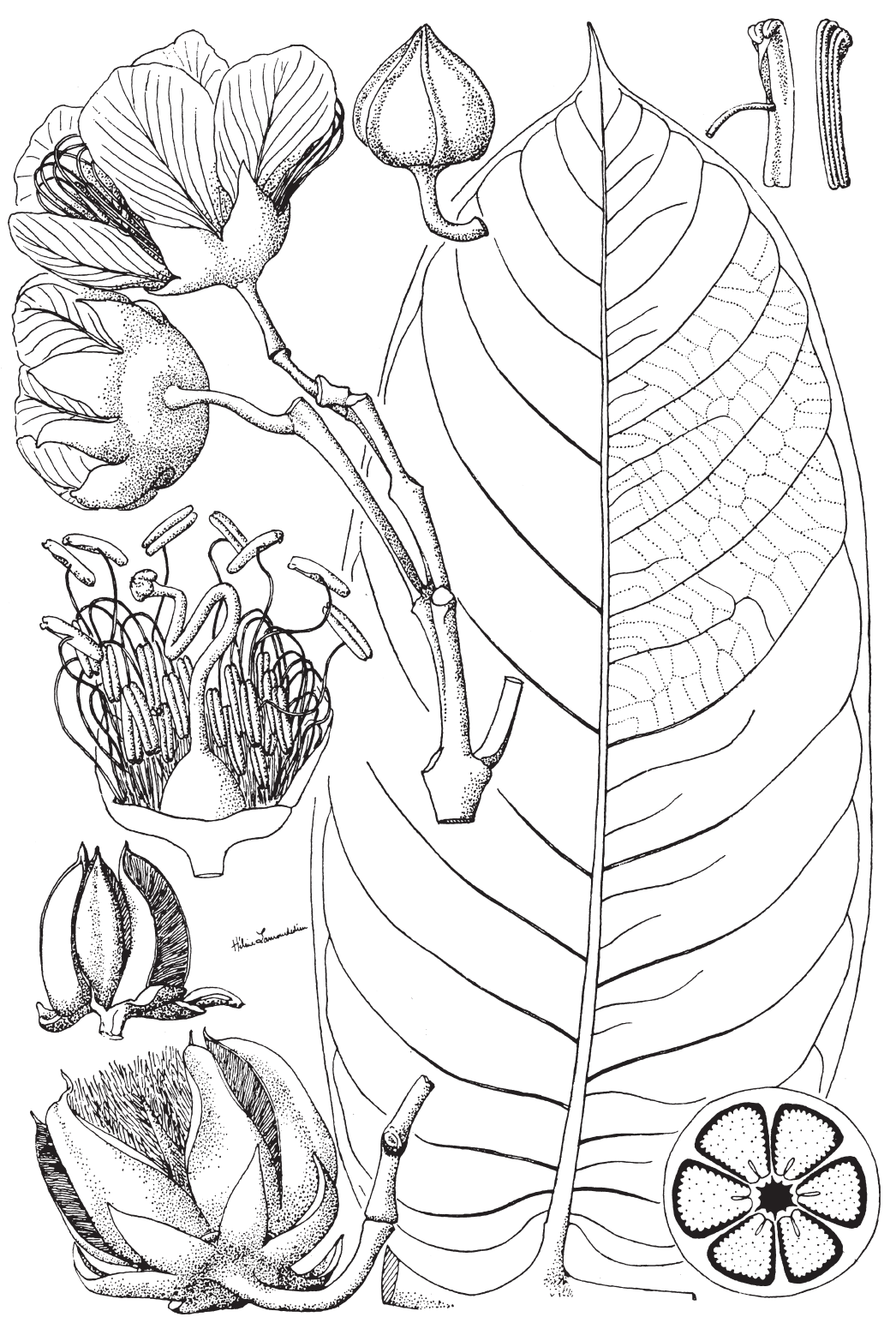

Fig. 44. Duabanga grandiflora (DC.) Walpert (Sonneratiaceae).

Uses - Wood used for tea-boxes and for house and boat-building, planks, canoes, oars, and umbrellas. Fruits and leaves boiled for traditional black dye. Fruits edible, used boiled as vegetable.

Specimens examined: Balansa 3864 (P); Chevalier 31325, 39963 (P); Eberhardt 2876 (P); Evrard s.n. (P); Harmand 50 (P); Hayata $662(\mathrm{P})$; Hiep $362(\mathrm{P})$; Jean 38399 (P); Pételot $3942(\mathrm{P})$; Poilane 1266, 20130, 24766, 25503 (P); Pierre 536 (P); Schmid s.n. (P); Spire 1162 (P); Thorel 2688 (P). 


\section{STERCULIACEAE}

Trees or shrubs, rarely herbs, with stellate hairs or scales. Trees usually with prominent plank buttresses. Inner bark usually prominently radially streaked, or with wedges, generally tough due to long fibres. Leaves simple, palmate or digitately compound, alternate or spirally arranged. Stipules present. Petioles often long and kneed. Inflorescences various, usually axillary and compound, sometimes flowers solitary. Flowers unisexual or bisexual, regular, rarely irregular. Sepals 3-5, valvate, partly connate or rarely free. Petals 5 or absent, contorted or imbricate, free or adnate at the base to the staminal tube, often persistent. Stamens 5, 10, 15 or more, free or connate into a narrow tube, and sometimes with staminodes, anthers 2-locular. Ovary superior, carpels 2-5, rarely 1 or $10-12$, united or free, ovule(s) 1 or 2 or more in each carpel, inserted at the inner angle, style simple or divided into lobes, rarely free to the base. Fruit dehiscent or indehiscent, winged or not, fleshy to leathery or woody, often separating as mericarps. Seeds sometimes arillate, winged or not.

Distribution - Widespread in the tropics, subtropics, and rarely in temperate regions: c. 60 genera, c. 700 species. In Laos and Vietnam: c. 17 genera, c. 74 species.

\section{PTEROSPERMUM Schreb.}

\section{KEY TO THE SPECIES}

1a. Young leaves palmate, mature leaves elliptic, base oblique, apex pointed. Stipules linear. Fruit a terete, not ridged capsule ............ 1. P. heterophyllum

b. Young leaves reniform, mature leaves obovate, truncate or heart-shaped at base, apex 3-5-lobed. Stipules divided. Fruit a capsule, with 5 straight longitudinal ridges

2. P. truncatolobatum

\section{Pterospermum heterophyllum Hance}

Vernacular names - Ham ao (L); Mang xanh, Long mang, Long mang thuong (V).

Trees up to $20 \mathrm{~m}$ high, up to $60 \mathrm{~cm}$ diameter. Bark greyish brown, inner bark pink, soft and fibrous. Leaves and young twigs densely covered with brownish yellow stellate hairs. Stipules linear, 8-14 mm long. Leaves simple, alternate. Young leaves palmate, $17-30 \mathrm{~cm}$ diameter. Petioles $20-30 \mathrm{~cm}$ long. Mature leaves elliptic $6-16$ by $3-7 \mathrm{~cm}$, base oblique, margin entire, apex pointed, upper surface yellow brown, lower surface covered with brownish yellow stellate hairs. Petioles $1-2.5 \mathrm{~cm}$ long. Inflorescences axillary, solitary, or in clusters of 2-4 flowers. Sepals 5, free, linear, covered with densely stellate hairs outside, whitish brown and long hairs inside. Petals 5, strapshaped, glabrous. Stamens 15 , connate into 5 bundles, staminodes 5, linear, alternating with stamen bundles. Ovary ovoid, densely tomentose, 5-locular, ovules numerous. Style slender, hairy. Fruit a capsule, narrow elliptic, woody, $4-6$ by $2.5-3.5 \mathrm{~cm}$, dark brown tomentose, splitting into 5 pieces when mature. Seeds winged, 3-4 cm long.

Distribution - India, China, Indochina, Thailand. In Vietnam: in most provinces in North and Central. In Laos: not yet recorded but presumably occurring.

Habitat \& Ecology - Primary and secondary forest, altitude below $700 \mathrm{~m}$. Usually confined to mountainous and limestone regions. Light demanding tree, prefers soils 
with medium humidity. Coppice regeneration is good. Flowering: April, May; fruiting: February, March next year.

Uses - The wood is reddish brown, used for making furniture, flooring, plywood, and is suitable for the production of pulp. Leaves and bark are rich in tannins; they are sometimes applied in traditional medicine, such as a poultice against itch and to treat wounds.

Specimens examined: Cavalerie 3483 (P); How 70856 (P); Tsiang 695 (P); Wang 695, 34757, $52198(\mathrm{P})$.

\section{Pterospermum truncatolobatum Gagnep.}

Vernacular names - Ham ao (L); Mang cụt, Lòng mang cụt (V).

Trees up to $25 \mathrm{~m}$ high, up to $80 \mathrm{~cm}$ diameter. Bark greyish brown, inner bark 1-1.5 $\mathrm{cm}$ thick, greyish yellow, with long fibres. Stipules 6-10 mm long, divided. Leaves and young twigs densely covered with brownish yellow stellate hairs. Young leaves reniform, $15-30 \mathrm{~cm}$ diameter. Petioles $10-20 \mathrm{~cm}$ long. Mature leaves obovate, $8-17$ by $4-8 \mathrm{~cm}$, truncate or heart-shaped at base, margin entire, apex with 3-5 lobes, upper surface yellow brown, lower surface covered with brownish yellow stellate hairs. Petioles 8-15 mm long. Flower bisexual, axillary, subsessile. Sepals 5, free, linear, covered with densely stellate hairs outside, white and long hairs inside. Petals 5 , bellshaped, glabrous. Stamens 15 , connate into 5 bundles, staminodes 5 , linear, alternating with the stamen bundles. Ovary ovoid, densely tomentose, 5-locular, ovules numerous, style slender, hairy. Fruit a capsule, oblong, woody, $4-8$ by $2.5-4 \mathrm{~cm}$, with 5 straight longitudinal ridges, dark brown tomentose, splitting into 5 pieces when mature. Seeds winged, 3-4 cm long.

Distribution - Confined to Indochina. In Laos: this species is found in Vientiane province. In Vietnam this species is common in many provinces such as Lào Cai, Yên Bai, Tuyên Quang, Hà Giang, Hoa Binh, Ninh Binh, Hà Tây, Thanh Hoa, Nghê An, Hà Tinh, Quang Binh, Da Nang, Kom Tum, and Gia Lai.

Habitat \& Ecology - Secondary forest, altitude below $700 \mathrm{~m}$. Light demanding tree. Coppice regeneration is good. Flowering: April to June; fruiting: January to March.

Uses - Wood is reddish brown. Used for making furniture, flooring, plywood, boxes, and is suitable for the production of pulp. Leaves and bark rich in tannins, sometimes applied in traditional medicine, such as a poultice against itch and to treat wounds.

Specimens examined: Balansa 1305 (P); Bon 4862 (P); Cavalerie 3483 (P); Poilane 11104 (P).

\section{THEACEAE}

Small to large evergreen trees. Bark fibrous. Stipules absent. Leaves simple, alternate or spirally arranged, rarely subopposite, more or less coriaceous, margin entire or serrate. Flowers regular, usually bisexual, rarely unisexual, single, rarely fascicles, axillary or extra-axillary, rarely terminal, mostly 5-merous, often showy. Bracteoles 2 or 3 at the base of calyx. Sepals usually 5 , free or slightly connate, overlapping, often unequal. Petals usually 5, free or connate at the base, overlapping. Stamens numerous adnate to petals, anthers attached to filament at the base (basifixed) or attached to filament at the apex (versatile), opening longitudinal. Ovary superior, rarely half inferior, lacking 
stalk, usually 2-5-locular, ovules 2 to many in each locule, rarely 1 , style(s) $1-5$, free or partly united; stigma usually small, head-like (capitate) or entire. Fruit a capsule or berry with persistent sepals at the base and style at apex. Seeds small, few or many, sometimes winged (Schima).

Distribution - Tropical or subtropical regions, mainly in America and Asia, a few in Africa: c. 16 genera, c. 600 species. In Laos and Vietnam: c. 9 genera, 98 species.

SCHIMA Reinw. ex Blume

Schima wallichii (DC.) Korth. - Fig. 45

Synonyms - Gordonia wallichii DC.; Schima crenata Korth.; S. noronhae Reinw. ex Blume

Vernacular names - Mi (Xieng Khouang), Khai so, Thalo in other provinces (L); Vối thuốc (V).

Trees up to $30 \mathrm{~m}$ high, up to $70 \mathrm{~cm}$ diameter. Buttresses, if present, up to $180 \mathrm{~cm}$ high. Bark dark grey to black, scaly or cracked in small thick pieces, inner bark pink or dark red, with dark spots, containing fibres which can cause skin irritation. Sapwood white.

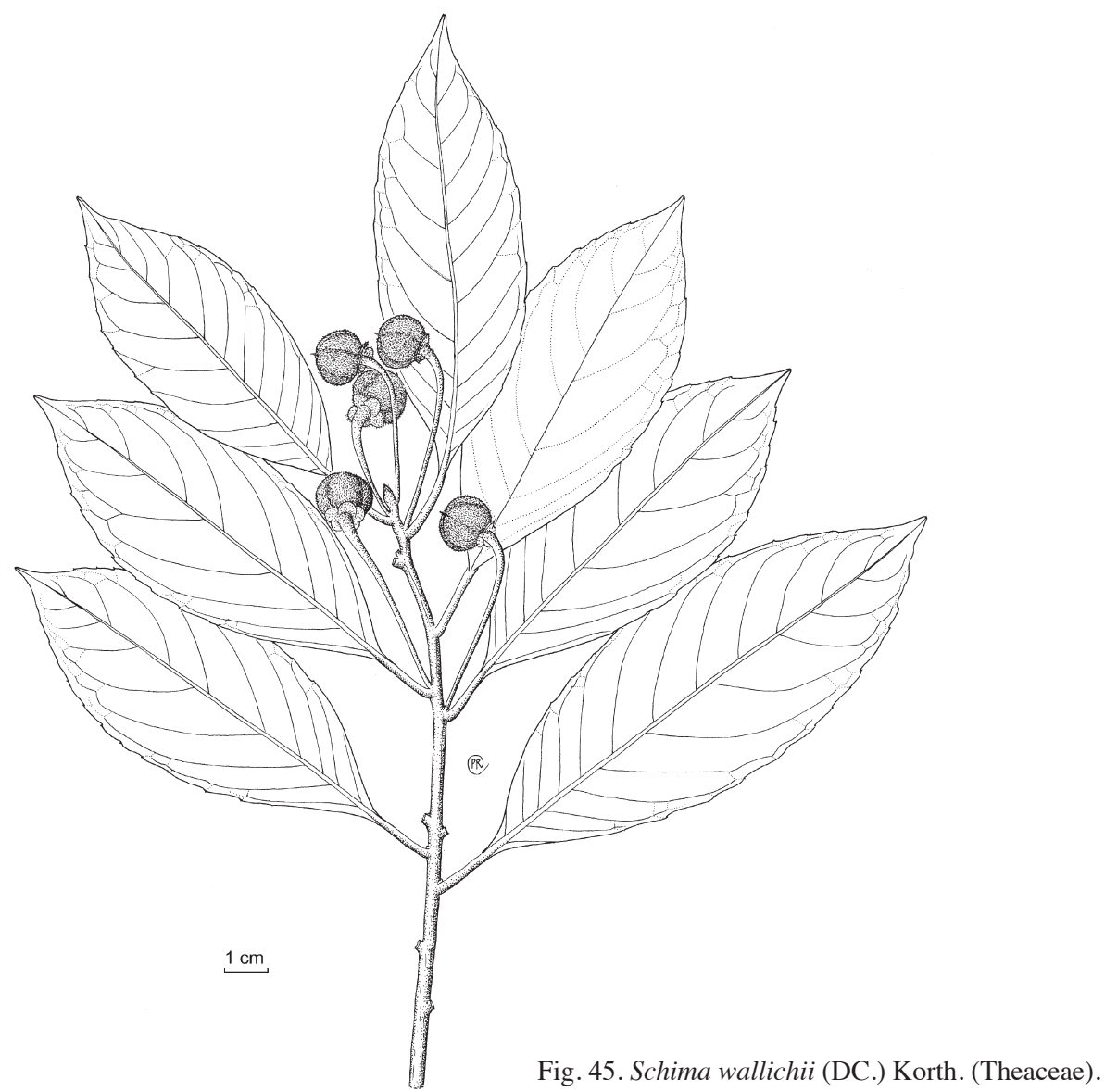


Young leaves orange to red brown and densely covered with silky hairs. Leaves spirally arranged, broadly elliptic, $6-20$ by $3-8 \mathrm{~cm}$, base cuneate, apex acute to acuminate, margin more or less toothed, secondary veins $6-8$ pairs. Petioles $1.5-3 \mathrm{~cm}$ long with fine short hairs (slightly pubescent). Flowers axillary, solitary or clustered in the axils of leaves near or at the end of the twigs, $17-35 \mathrm{~mm}$ diameter. Pedicel $1-2.5 \mathrm{~cm}$ long. Bracteoles 2. Sepals 5, more or less rounded, glabrous. Petals 5 , shortly connate at the base, obovate, up to $2 \mathrm{~cm}$ long, white, aromatic. Stamens many, unequal, filaments glabrous, anthers elliptic. Ovary 5-locular, with 2 or 3 ovules in each locule. Fruits a woody capsule, almost globose, $1-3 \mathrm{~cm}$ diam., silky, opening by 5 valves, stalk 1.3-2 $\mathrm{cm}$ long. Seeds kidney-shaped, $8 \mathrm{~mm}$ long, winged.

Distribution - India, Nepal, Myanmar, South China, Indochina, Thailand, Peninsular Malaysia, Indonesia (West Java, Borneo), Philippines (Palawan). In Laos: Louang Prabang, Houa Phan, Xieng Khouang, Savannakhet, and Saravane provinces. In Vietnam: Lào Cai, Cao Bang, Lai Châu, Ninh Thuân, Kon Tum, and Hà Bac provinces.

Habitat \& Ecology - Light demanding when mature, shade tolerant when young, cold-tolerant tree. The trees often grow in primary and secondary forest, well-drained land, altitude up to $3000 \mathrm{~m}$, but most abundant in regions above $400 \mathrm{~m}$. Flowering: March, April; fruits: January to March.

Uses - Wood red-brown, hard, used for timber, house construction, furniture, boats, plywood, agricultural implements. The leaves are used for fodder.

Note - This species is very variable, our material was mainly formerly identified as $S$. wallichii subsp. noronhae (leaf mostly quite entire) and some specimens as subsp. oblata (leaf slightly crenate, dentate). However, the great overlap in many characters keeps us from accepting subspecies.

Specimens examined: Averyanov et al. VH 1389 (P); Chevalier 29576 (P); Dussaud 4 (P); Kerr 21116 (P); Lau 3677 (P); Mekee 6049 (P); Pierre 1413 (L); Pételot 4458 (P); Poilane 2009, 2339, 5920, 7728, 13725, 18813, 19059, 20035, 20363, 26813, 27092 (P); Simond 6049 (P); Thao Kham $4458(\mathrm{P})$; Thorel $2768(\mathrm{P})$.

\section{THYMELAEACEAE}

Trees, shrubs, or climbers, with a tough and fibrous 'silvery' inner bark. Stipules absent. Leaves simple, opposite, decussate, spirally arranged or alternate, entire. Petioles very short. Inflorescences terminal, axillary, sometimes on sessile or peduncled, racemose, umbelliform, spicate, capitate, or fascicled. Flowers bisexual, rarely unisexual, regular. Bracts present, usually fragrant. Calyx tubular, often brightly coloured, shallowly or deeply 4- or 5-lobed, imbricate. Petals absent or 4-12 scales, inserted on the throat of calyx tube or slightly lower. Stamens 2 or many, usually as many as twice the calyx lobes and opposite them. Disc scale-like, annular, or cupshaped, sometimes absent. Ovary superior, 1- or 2- or (3-5- in Gonystylus) locular, 1 ovule in each locule, style filiform, caducous, sometimes very short or obscure, stigma globose, pyramidal, sometimes papillose. Fruit a drupe, a berry, or a capsule. Seeds with caruncle or aril.

Distribution - Throughout the tropical and subtropical regions of the world, strongly developed in the drier parts of Africa and Australia: c. 50 genera, 500 species. In Laos: c. 4 genera, c. 4 species. In Vietnam: c. 7 genera, c. 16 species. 


\section{AQUILARIA Lam.}

Aquilaria crassna Pierre ex Lecomte - Fig. 46

Synonym - Aquilaria agallocha Roxb.

Vernacular names - Ketsana (L); Trầm, Trầm hương, Dó, Dó bầu (V).

Trees up to $30 \mathrm{~m}$ high, up to $100 \mathrm{~cm}$ diameter. Branches drooping. Bark brownish grey, shallowly fissured and flaking in thin strips, inner bark pale yellow with patches of fragrant, dark coloured resin in old trees. Leaves simple, alternate, spirally arranged, coriaceous, elliptic, $5-11$ by $3-6 \mathrm{~cm}$, base broadly cuneate, margin entire but often wavy, apex acuminate or acute, dark or purple-green above, shining, light green beneath, glabrous, veins 15-20 pairs, more conspicuous beneath, veins and veinlets slender. Petioles 3-7 mm, pubescent. Inflorescences umbellate, axillary or terminal. Flowers fragrant, yellowish green. Pedicels 5-6 mm, densely yellow-grey-pubescent. Calyx tube narrowly bell-shaped, 5-6 mm, densely pubescent on both sides, lobes 5, ovate. Petals 10, scale-like, inserted on the throat of the calyx tube, densely pubescent. Stamens 10, in 2 rows, filaments c. $1 \mathrm{~mm}$ long, anthers oblong. Ovary ovoid, densely with greyish white hairs, 2-locular, style absent or very short, stigma capitate. Fruit a

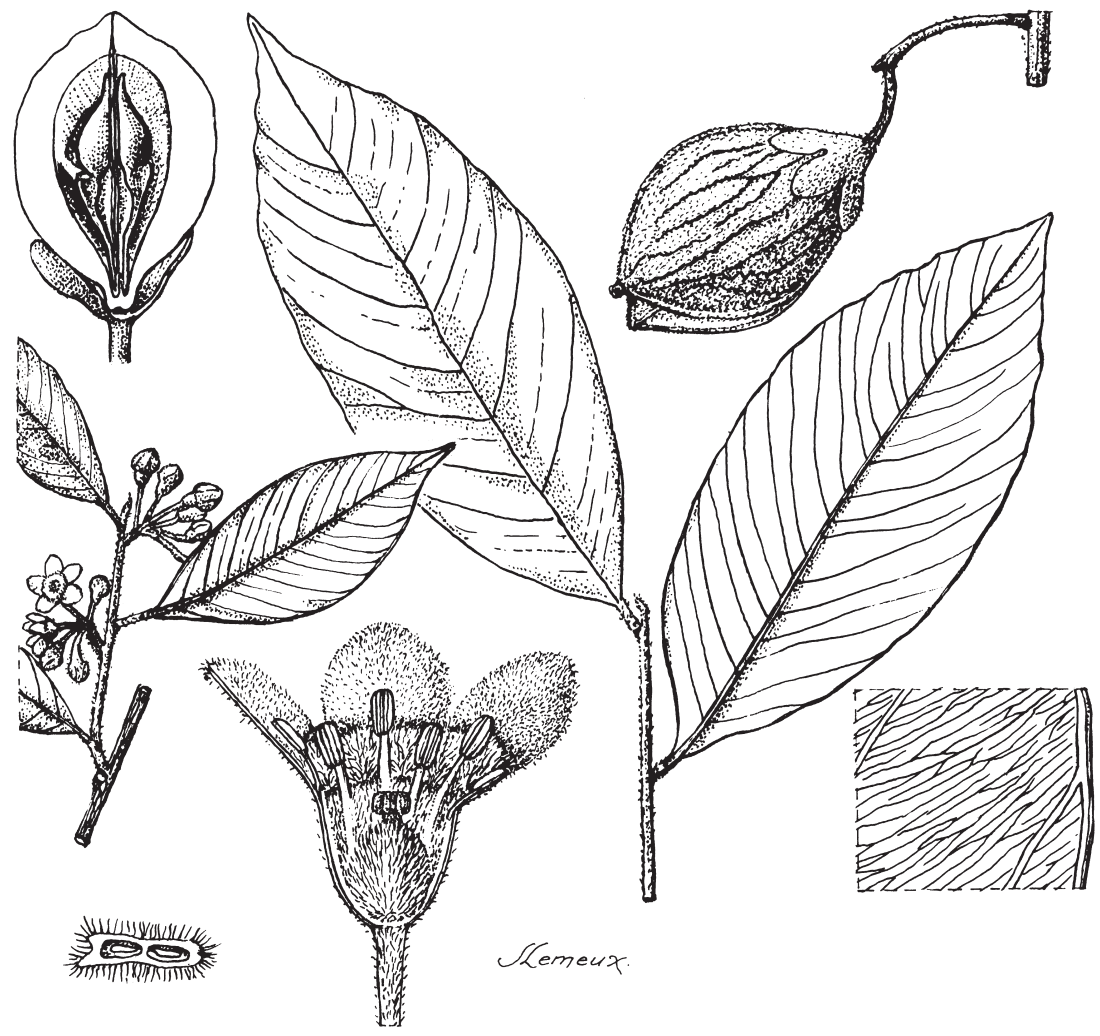

Fig. 46. Aquilaria crassna Pierre ex Lecomte (Thymelaeaceae). 
capsule, ovoid, green and silky hairy when young, $2-4$ by $2-3 \mathrm{~cm}$, calyx persistent at base. Seed $(s) 1$, sometimes 2 , ovoid, brown, c. 10 by $5 \mathrm{~mm}$.

Distribution - India, Bangladesh, Myanmar, China, Indochina, Thailand, Malaysia. In Laos: in most provinces, such as Houa Phan, Xieng Khouang, Vientiane, Savannakhet, Champassak, and Attopeu. In Vietnam: in many provinces, such as Lang Son, Son La, Lào Cai, Yên Bai, Lai Châu, Tuyên Quang, Hà Giang, Binh Ninh, Hoa Binh, Thanh Hoa, Nghê An, Hà Tinh, Quang Binh, Dac Lac, and Kiên Giang.

Habitat \& Ecology - Primary and secondary forest, altitude up to $1000 \mathrm{~m}$. This species is well adapted to various habitats, including rocky, sandy, or well-drained slopes, ridges and land near swamps. Light-demanding tree, but tolerant to shade when young. Flowering: April to June; fruiting: July to September.

Uses - Wood soft, used for general furniture, cosmetic preparation, clothing articles, and musical instruments. Bark used for hammock making and paper pulp. Resin used as traditional medical to treat asthma, chest congestion, colic, diarrhoea, diuretic, kidney problems, nausea, thyroid cancer, and lung tumours.

Note - Nowadays this species is very rare, because the resin of the infected and cut trees is much sought after and yields a very high price.

Specimens examined: Fourdan 39112 (P); Kerr 10043 (L); Pierre 1443, 1449, 3619 (P); Poilane $1111,5411,6680(\mathrm{P}), 6400(\mathrm{~L}, \mathrm{P})$.

\section{TILIACEAE}

Trees, shrubs, or herbs, rarely climbers, with stellate hairs or scales. Bark fibrous. Stipules early caducous. Leaves simple, alternate or spirally arranged, lobed or not, base 3-7-veined. Inflorescences cymes, racemes or panicles, solitary. Flowers regular, 5 -merous, bisexual, rarely unisexual. Sepals 5, free or united. Petals absent, or present and free, alternate with the sepals. Stamens many, free or shortly connected at the base or in 5-10 bundles with slender filaments arising from a thickened ring around the ovary, anthers 2-locular, opening by a slit lengthwise or by an apical pore. Ovary superior, sessile or stalked, 2-10-locular, ovule 2 to many per locule, style awl-shaped or branched, stigma lobed or pointed. Fruit dry or fleshy, splitting or not, winged or not. Seed (s) 1 to many in each locule, endosperm present, wings absent.

Distribution - Widely distributed in the tropical and temperate zones: 55 genera, c. 1130 species. In Laos and Vietnam: c. 18 genera, 60 species.

\section{BERRYA Roxb.}

\section{Berrya mollis Wall. ex Kurz}

Synonym - Berrya ammonilla Roxb. var. mollis Mast.

Vernacular names - Lieng, Lieng khai (L); Gia ti (V).

Deciduous trees up to $20 \mathrm{~m}$ high, up to $25 \mathrm{~cm}$ diameter. Bark pale brown or grey, slightly cracked, inner bark pale yellow. Leaves broadly ovate or circular, $6-15$ by $7-18 \mathrm{~cm}$, base heart-shaped, margin entire or irregularly wavy, apex shortly cuspidate or acute, 
mature leaves softly hairy on lower surface, secondary veins 3-7 pairs, venation ladderlike, distinct on lower surface. Petioles $2-8 \mathrm{~cm}$ long, hairy. Inflorescences terminal or axillary, 5-20 cm long. Flowers globose in bud, c. $5 \mathrm{~mm}$ diam., white. Sepals sometime 3-merous, ovate. Petals slightly spoon-shaped, rather longer than sepals, 4-5 by 1-2 $\mathrm{mm}$. Stamens many, smooth, anthers attached at base. Ovary globose, 3-locular, hairy, style slender, stigma pointed. Fruit a globose capsule, hairy, $3.5-5.5$ by $1 \mathrm{~cm}$, splitting in 3 sections, each with a pair of wings, thinly hairy, pinkish brown when ripe.

Distribution - India, Myanmar, Indochina, Thailand. In Laos: Sayabouri, Vientiane, and Savannakhet provinces. In Vietnam: Dông Nai province.

Habitat \& Ecology - In moist upper mixed deciduous forest, altitude 100-1000 m. Flowering and fruiting: April to September.

Uses - Wood used in construction of rims, beams, or cartwheels.

Specimens examined: Bejaud 739 (P); Maxwell 91-898 (P); Pierre 1492 (P); Poilane 28014 (P); Sangkhachand $1661(\mathrm{P})$; Spire $188(\mathrm{P})$; Thorel $2111(\mathrm{P})$; Tixier s.n. $(\mathrm{P})$.

\section{VERBENACEAE}

Trees, shrubs, or lianas. Twigs often lenticellate, young twigs quadrangular. Stipules absent. Leaves generally opposite, rarely whorled, simple, palmate, trifoliolate or pinnate. Inflorescences in clusters, panicles, cymes, racemes or spikes, axillary or terminal. Flowers small or large, bisexual, general bilateral. Calyx usually tubular with 4 or 5 lobes or teeth. Corolla usually 2-lipped, more or less funnel- or trumpet-shaped with a short or long tube, lobes 4 or 5 . Stamens 5,4 or 2, inserted in the corolla tube, projecting out of flower or not, anthers 2-celled. Ovary superior, 2-4-celled, often 4-lobed, ovule(s) 1 or 2 in each cell, style one, stigma entire or bifid. Fruit a drupe or capsule, seated on or enclosed in the usually enlarged persistent calyx. Seed $(s) 1-4$, small.

Distribution - Widely distributed in tropical and subtropical regions: c. 76 genera, 3000 species in the world. In Vietnam: c. 8 genera, c. 22 species.

\section{KEY TO THE GENERA}

1a. Petiole terete, not winged. Flower usually large, corolla with 5 unequal lobes, 2 upper lobes and 3 lower lobes, stamens 4, 1 pair longer than the other. Fruit with persistent calyx at base $\ldots \ldots \ldots \ldots \ldots \ldots \ldots \ldots \ldots \ldots \ldots \ldots \ldots$. Gmelina

b. Petiole usually narrowly winged. Flower usually small, corolla with 5 or 6 equal lobes, stamens 5 or 6 , equal. Fruit enclosed by calyx . . . . . . 2. Tectona

\section{GMELINA L.}

\section{Gmelina arborea Roxb.}

Synonyms - Gmelina rheedii Hook.; Premna arborea (Roxb.) Roth

Vernacular names - So (L); Lỏi thọ (V).

Large trees up to $30 \mathrm{~m}$ high, up to $100 \mathrm{~cm}$ diameter. Bole straight, cylindrical. Bark smooth, greyish brown, with many black lenticels, inner bark cream-coloured. Young 
twigs quadrangular, covered with yellow hairs becoming fulvous. Leaves simple, opposite, broadly ovate, $10-19$ by $7-14 \mathrm{~cm}$, base cuneate or slightly heart-shaped, with 2-6 rounded glands near petiole, margin entire, apex pointed, young leaves densely covered with yellow stellate hairs, mature leaves glabrous or with scattered hairs below, lateral veins 4-7 pairs per side. Petioles 4-11 cm long, slender, with two glands at the top of the petiole and 2-6 glands at the base of the leaf blade. Inflorescences panicle, axillary or terminal, up to $40 \mathrm{~cm}$ long, hairy. Flowers bisexual, large. Calyx cup-shaped, with 4 or 5 short teeth, densely brown hairy outside. Corolla funnel-shaped, creamy-violet or creamy-pink, with 5 unequal lobes, upper 2 lobes and lower 3 lobes with the middle lobe much larger than the side ones, usually hairy outside. Stamens 4,1 pair longer than the other, inserted on corolla tube. Ovary smooth, styles 2, stigma divided. Fruit a drupe, ovoid, $1.5-2.5 \mathrm{~cm}$ long, with persistent calyx at the base. Seed(s) 1 or 2.

Distribution - Pakistan, Sri Lanka, India, Myanmar, China, Indochina, Malaysia, and planted in many Asian countries, Africa, Brazil. In Laos: Louang Namtha, Sayabouri, and Attopeu provinces. In Vietnam: Tuyên Quang, Hà Giang, Lang Son, Lai Châu, Son La, Vinh Phu, Quang Ninh, Bac Thai, and Ninh Binh provinces.

Habitat \& Ecology - Primary and secondary tropical forest, or along streams or river banks. Usually mixed with Canarium album, Castanopsis fissa, Castanopsis indica, Endospermum sinensis, and Engelhardtia chrysolepis. Fast-growing and light demanding tree. Flowering: April to June; fruiting: October to December.

Uses - Wood whitish grey, fine grain. Mainly used for light construction, pulping, sawing boards, making furniture, musical instruments, matches, and packing boxes. Fruits and bark have medicine properties against bilious fever. This species is also used as ornamental species in landscaping.

Specimens examined: D'Alleizette s.n.(L); Glutron 37988 (P); Harmand 187, 1377 (P); Maxwell 75-318, 76-58, 88-218, 88-431, 88-981, 90-252, 94-294, 94-398 (L); Pételot 4536 (P); Pierre 1901 (P); Poilane $13635(\mathrm{P})$.

\section{TECTONA L.f.}

\section{Tectona grandis L.f.}

Synonym - Tectona theka Lour.

Vernacular names - Sak (L); Tếch (V).

Large trees up to $30 \mathrm{~m}$ high, $150 \mathrm{~cm}$ diameter. Bole straight, cylindrical, usually canaliculated and buttressed at the base. Bark greyish yellow, longitudinally splitted into small scales, inner bark with red, sticky sap, fibrous. Twigs quadrangular, covered with rusty stellate hairs. Leaves simple, opposite, broadly obovate, $16-60$ by $12-40 \mathrm{~cm}$, base attenuate to the petiole, apex pointed, young leaves densely covered with yellow stellate hairs, mature leaves rough above, softly hairy below, venation pinnate, veins scalariform. Petioles 1-5 cm long, narrowly winged. Inflorescences panicles, up to $50 \mathrm{~cm}$ long. Bracts elliptic. Flowers bisexual, small. Calyx tube bell-shaped, 5-lobed, densely brown hairy, red dots outside. Corolla funnel-shaped at base, with 5 or 6 equal lobes, white, hairy outside. Stamens 5 or 6 , equal, attached on the base of the corolla. Ovary conical, densely outside, style as long as stamens, stigma bifid. Fruit a globose 
drupe, 1-2 cm diam., densely tomentose, enclosed by calyx, green when young, yellow when mature.

Distribution - Naturally occurring in India, Myanmar, Thailand (northern), and Laos. Introduced into Indonesia (especially Java) and other Asian countries. Teak is also found in the Caribbean region, Florida, Virgin Islands and Hawaii, and in China. In Laos: occurs naturally in Sayabouri province and is introduced in many other provinces. In Vietnam: planted from beginning of the 20th century onward, and is now commonly planted in many provinces.

Habitat \& Ecology - Teak grows in mixed tropical deciduous forest and develops well on limestone soils, altitude below $1000 \mathrm{~m}$. Light demanding, even when young, seedlings cannot tolerate frost. Natural and coppice regeneration are good, this species can even tolerate regular forest fires. Flowering: May to July; fruiting: November to January.

Uses - Timber dark yellow, grain gross but fine, resistant to termites and insects. Used for construction, ship making, railway sleepers, and furniture. Young leaves serve as wrapper in preparing food. Boiled leaf extract is used to treat bleeding of larynx, trachea, bronchi, or lungs, and sore throat. In traditional medicine, a wood powder paste has been used against bilious headaches and swellings. The charred wood soaked in poppy juice and made into a paste is used to relieve the swelling of eyelids. The bark has been used as an astringent and the wood oil as a hair tonic. This species is also used as an ornamental and for landscaping.

Specimens examined: Guillemin 668 (P); Iwatsuki et al. 9446 (L); Kerr 1297 (L); Kostermans 737, 4719 (L); Koyama 32178 (L); Maxwell 89-1078(L); Murata et al. 17739 (L); Pierre 1275 (P); Plee 720 (P); Thomson s.n.(L).

\section{INDEX TO SCIENTIFIC NAMES}

Numbers refer to the pagenumber. Accepted names are in roman type and synonyms in italics.

Acacia

lebbeck (L.) Willd. 299

odoratissima (L.f.) Willd. 301

procera (Roxb.) Willd. 302

xylocarpa (Roxb.) Willd. 309

Acrocarpus Wight \& Arn. 244

combretiflorus Teijsm. \& Binn. 244

fraxinifolius Wight \& Arn. 244

Adenanthera L. 297

microsperma Teijsm. \& Binn. 297

pavonina $\mathrm{L}$.

var. microsperma (Teijsm. \& Binn.)

I.C. Nielsen 297

Afzelia Sm. 245

cochinchinensis (Pierre) Leonard 245

siamica Craib 245

xylocarpa (Kurz) Craib 245

Aglaia Lour. 293

gigantea Pellegr. 293

spectabilis (Miq.) S.S. Jain \& Bennet 293
Albizia Durazz. 299

lebbeck (L.) Benth. 299

odoratissima (L.f.) Benth. 301

procera (Roxb.) Benth. 302

saman (Jacq.) F. Muell. 307

Aleurites J.R. Forst. \& G. Forst. 275

ambinux Pers. 275

lobata Blanco 275

moluccana (L.) Willd. 275

Alstonia R.Br. 233

scholaris (L.) R.Br. 233

Altingia Noroña 224

gracilipes Hemsl. 224

siamensis Craib 224

takhtajanii Thai 224

Altingiaceae 223

Amoora gigantea Pierre 293 spectabilis Miq. 293

Anacardiaceae 226 
Anisoptera Korth. 263

cochinchinensis Pierre 263

costata Korth. 263

oblonga Dyer 263

robusta Pierre 263

Annonaceae 229

Anogeissus 258

acuminata (Roxb. ex DC.) Guill. ex Perr. 258

harmandii Pierre 258

Apocynaceae 232

Aquilaria Lam. 341

agallocha Roxb. 341

crassna Pierre ex Lecomte 341

Archidendron F. Muell. 303

clypearia (Jack) I.C. Nielsen var. clypearia 303

Baccaurea Lour. 277

cauliflora Lour. 277

oxycarpa Gagnep. 277

ramiflora Lour. 277

sapida (Roxb.) Müll.Arg. 277

Bassia pasquieri Lecomte 334

Berrya Roxb. 342

ammonilla Roxb. var. mollis Mast. 342

mollis Wall. ex Kurz 342

Betula L. 236

acuminata Wall. 236

alnoides Buch.-Ham. 236

Betulaceae 236

Betulaster acuminata Spach 236

Bignonia indica L. 238

pentandra Lour. 238

stipulata (Wall.) Roxb. 237

Bignoniaceae 237

Bischofia Blume 278

javanica Blume 278

trifoliata Hook. 278

Bombacaceae 240

Bombax L. 240

ceiba L. 240

malabaricum DC. 240

thorelii Gagnep. 240

Broussonetia Vent. 310

papyrifera (L.) Vent. 310

Burseraceae 241

Caesalpinia L. 246

dasyrhachis Miq. 251

sappan L. 246

Caesalpiniaceae 243

Calophyllum nagassarium Burm.f. 256

Calosanthes indica (L.) Blume 238

Cananga Hook.f. \& Thomson 230 odorata (Lam.) Hook.f. \& Thomson 230
Canarium L. 242

album (Lour.) Raeusch. 242

pimela Leenh. 243

tonkinensis Engl. 242

tramdenum C.D. Dai \& Yakovlev 243

Caryophyllus L. 315

Cassia L. 248

fistula L. 248

siamea Lam. 252

Castanea Tourn. ex L. 281

duclouxii Dode 281

fargesii Dode 281

hupehensis Dode 281

indica Roxb. ex Lindl. 283

mollissima Blume 281

Castanopsis Spach 282

cerebrina (Hickel \& A. Camus) Barnett 282

indica (Roxb. ex Lindl.) A.DC. 283

sinensis A. Chev. 283

subacuminata Hayata 283

Chickrassia tabularis (A. Juss.) Wight \& Arn. 296

Chisocheton Blume 295

balansae C.DC. 295

chinensis Merr. 295

cochinchinensis Pierre 295

cumingianus (C.DC.) Harms 295

paniculatus Hiern 295

siamensis Craib 295

Choerospondias Burtt \& Hill 226

axillaris (Roxb.) Burtt \& Hill 226

Chukrasia A. Juss. 296

tabularis A. Juss. 296

Cinnamomum Schaeff. 286

aromaticum Nees in Wall. 286

balansae Lecomte 287

camphora (L.) T. Nees \& C.H. Eberm. 287

cassia Blume 286

glaucescens (Nees) Hand.-Mazz. 287

iners Reinw. ex Blume 288

nitidum Hook. 288

paraneuron Miq. 288

Clusiaceae 256

Combretaceae 257

Conocarpus acuminata Roxb. ex DC. 258 hirtus Buch.-Ham. ex Wall. 258

Cupressaceae 213

Cupressus L. 213

funebris Endl. 213

hodginsii Dunn 215

tonkinensis Silba 213

Dacrycarpus (Endl.) de Laub. 220

imbricatus (Blume) de Laub. 220 
Dacrydium Sol. ex G. Forst. 221

elatum (Roxb.) Wall. ex Hook. 221

pierrei Hickel 221

Dalbergia L.f. 317

bariensis Pierre 322

cambodiana Pierre 318

cochinchinensis Pierre 318

cultrata Benth. 320

dongnaiensis Pierre 322

duperreana Pierre 322

fusca Pierre 320

lanceolaria L.f. 321

mammosa Pierre 322

oliveri Prain 322

Dasillipe pasquieri Dubard 334

Datiscaceae 260

Decussocarpus fleuryi (Hickel) de Laub. 221

Delonix Raf. 248

regia (Bojer ex Hook.) Raf. 248

Dialium L. 249

cochinchinensis Pierre 249

Dillenia L. 261

ovata Wall. ex Hook.f. \& Thomson 261

Dilleniaceae 261

Diospyros L. 274 mun A. Chev. \& Lecomte 274

Dipterocarpaceae 262

Dipterocarpus C.F. Gaertn. 264

alatus Roxb. \& G. Don 265

gonopterus Turcz. 265

incanus Roxb. 265

lemeslei Vesque 265

macrocarpus Vesque 266

pubescens Koord. \& Valeton 266

retusus Blume 266

tonkinensis A. Chev. 266

Doona odorata (Roxb.) Burck 268

Dracontomelon Blume 227

dao (Blanco) Merr. \& Rolfe 227

duperreanum Pierre 227

mangiferum Blume 227

sinensis Stapf 227

Duabanga Buch.-Ham. 335 sonneratioides Buch.-Ham. 335 grandiflora (DC.) Walpert 335

Dysoxylum esquirolli H. Lév. 296

Ebenaceae 274

Eberhardtia Lecomte 332

tonkinensis Lecomte 332

Echites scholaris L. 233

Endospermum Benth. 280

chinense Benth. 280

Enterolobium saman (Jacq.) Prain 307
Erythrina L. 324

fusca Lour. 324

ovalifolia Roxb. 324

Eugenia cumini L. 315

jambolan Lam. 315

jambos L. 316

auct. 315

Euphorbiaceae 275

Fagaceae 280

Fagraea Thunb. 289

cochinchinensis A. Chev. 289

fragrans Roxb. 289

peregrine Blume 289

Fokienia A. Henry \& H.H. Thomas 215

hodginsii (Dunn) A. Henry \& H.H. Thomas 215

maclurei Merr. 215

Gmelina L. 343

arborea Roxb. 343

rheedii Hook. 343

Gordonia wallichii DC. 339

Hopea Roxb. 267

chinensis (Merr.) Hand.-Mazz. 267

hongayensis Tardieu 267

odorata Roxb. 268

Horsfieldia Willd. 312

amygdalina (Wall.) Warb. 312

thorelii Lecomte 312

tonkinensis Lecomte 312

Inga clypearia Jack 303

saman (Jacq.) Willd. 307

xylocarpa (Roxb.) DC. 309

Irvingia Hook.f. 284

harmandiana Pierre ex Laness. 284

malayana Oliv. ex A. Benn. 284

oliveri Pierre 284

Irvingiaceae 283

Jambosa Adans. 315

vulgaris DC. 316

Jatropha moluccana L. 275

Juniperus elata Roxb. 221

Keteleeria Carrière 216

davidiana Beissn. 216

delavayi Tiegh. 216

dopiana Flous 216

evelyniana Mast. 216

roulletii (A. Chev.) Flous 216

Knema Lour. 314

corticosa Lour. 314

globularia (Lam.) Warb. 314

Lagerstroemia L. 290

angustifolia Pierre ex Laness. 290

calyculata Kurz 290

grandiflora DC. 335 
Lauraceae 285

Laurus camphora L. 287

Lingoum cambodianum Pierre 328 indicum (Willd.) Kuntze 326 macrocarpum (Kurz) Kuntze 328 wallichii (Wight \& Arn.) Pierre 326

Liquidambar L. 225 acerifolia Maxim. 225

formosana Hance 225

maximoviczii Miq. 225

tonkinensis A. Chev. 225

Loganiaceae 288

Lythraceae 290

Madhuca J.F. Gmel. 334 pasquieri (Dubard) H.J. Lam 334

Magnolia mediocris (Dandy) Figlar 292

Magnoliaceae 291

Markhamia Seem. 237

indica P.H. Hô 237

stipulata (Wall.) Seem. ex K. Schum. 237

Meliaceae 293

Mesua L. 256

ferrea L. 256

nagana Gardner 256

nagassarium (Burm.f.) Kosterm. 256

Michelia L. 291

balansae Dandy 291

baviensis Finet \& Gagnep. 291

mediocris Dandy 292

tonkinensis A. Chev. 292

Mimosa dulcis Roxb. 306

lebbeck L. 299

odoratissima L.f. 301

procera Roxb. 302

saman Jacq. 307

xylocarpa Roxb. 309

Mimosaceae 296

Moraceae 310

Morus papyrifera L. 310

Myristica corticosa (Lour.) Hook.f. 314 globularia Lam. 314

Myristicaceae 311

Myrobalanus myriocarpa Kuntze 259

Myrtaceae 314

Myrtus cumini L. 315

Nageia Gaertn. 221

fleuryi (Hickel) de Laub. 221

neriifolia (D. Don) Kuntze 222

Opa Lour. 315

Oroxylum Vent. 238

indicum (L.) Kurz 238

Pahudia cochinchinensis Pierre 245 xylocarpa Kurz 245

Papilionaceae 317
Parashorea Kurz 269

chinensis H.C. Wang 269

Parkia R.Br. 305

dongnaiensis Pierre 305

insignis Kurz 305

macrocarpa Miq. 305

streptocarpa Hance 305

sumatrana Miq. 305

Pasania cerebrina Hickel \& A. Camus 282

Peltophorum (Vogel) Benth. 251

dasyrhachis (Miq.) Kurz 251

grande Prain 251

Pentacme siamensis (Miq.) Kurz 270

Pentaptera saja Buch.-Ham. 259

Pierardia sapida Roxb. 277

Pinaceae 216

Pinus L. 217

finlaysoniana Wall. ex Blume 218

insularis Endl. 217

kesiya Royle ex Gordon 217

khasya Hook.f. 217

langbianensis A. Chev. 217

latteri Mason 218

merkusiana Cooling \& Gaussen 218

merkusii Jungh. \& de Vriese 218

var. tonkinensis (A. Chev.) Gaussen 218

sumatrana Jungh. 218

sylvestris auct. 218

Pithecellobium Mart. 306

clypearia (Jack) Benth. 303

dulce (Roxb.) Benth. 306

saman (Jacq.) Benth. 307

Podocarpaceae 219

Podocarpus L'Hér. ex Pers. 222

annamensis N.E. Gray 222

fleuryi Hickel 221

imbricatus Blume 220

kawaii Hayata 220

neriifolius D. Don 222

Poinciana regia Bojer ex Hook. 248

Polyalthia Blume 231

cerasoides (Roxb.) Bedd. 231

Poupartia fordii Hemsl. 226

Premna arborea (Roxb.) Roth 343

Pterocarpus Jacq. 325

cambodianus (Pierre) Gagnep. 328

var. glaucinus (Pierre) Gagnep. 328

var. gracilis (Pierre) Gagnep. 328

var. parviflorus (Pierre) Gagnep. 328

indicus Willd. 326

macrocarpus Kurz 328

var. oblongus (Pierre) Gagnep. 328

pallidus Blanco 326

wallichii Wight \& Arn. 326

zollingeri Miq. 326 
Pterospermum Schreb. 337

heterophyllum Hance 337

truncatolobatum Gagnep. 338

Pyrus L. 329

kumaoni Decne. 329

pashia D. Don 329

variolosa Wall. 329

verruculosa Bertol. 329

Rosaceae 329

Samanea Merr. 307

saman (Jacq.) Merr. 307

Sapindaceae 331

Sapindus L. 331

microcarpus Jard. 331

mukorossi Gaertn. 331

saponaria L. 331

vitiensis A. Gray 331

Sapotaceae 332

Schima Reinw. ex Blume 339

crenata Korth. 339

noronhae Reinw. ex Blume 339

wallichii (DC.) Korth. 339

Senna Mill. 252

siamea (Lam.) Irwin \& Barneby 252

Shorea Roxb. ex C.F. Gaertn. 270

bracteata Pierre ex Laness. 270

chinensis (H.C. Wang) H. Zhu 269

chinensis Merr. 267

mekongensis Pierre ex Laness. 270

siamensis Miq. 270

wangtianshuea Y.K. Yang \& J.K. Wu 269

Sindora Miq. 253

cochinchinensis Baill. 253

siamensis Teijsm. 253

wallichii

var. siamensis (Teijsm. ex Miq.) Baker 253

Sonneratiaceae 335

Spathodea indica (L.) Pers. 238

stipulata Wall. 237

velutina Kurz 237

Spondias acuminata Gamble 226

axillaris Roxb. 226
Sterculiaceae 337

Sunaptea odorata Griff. 272

Swietenia chickrassa Roxb. 296

Syzygium Gaertn. 315

cumini (L.) Skeels 315

jambos (L.) Alston 316

Tamarindus L. 255

indica L. 255

occidentalis Gaertn. 255

officinalis Hook. 255

Tectona L.f. 344

grandis L.f. 344

theka Lour. 344

Terminalia 259

myriocarpa Van Heurck \& Müll.Arg. 259

saja Steud. 259

Tetrameles R.Br. 260

grahamiana Wight 260

nudiflora R.Br. 260

Theaceae 338

Thymelaeaceae 340

Tiliaceae 342

Tsuga roulletii A. Chev. 216

Uvaria odorata Lam. 230

Vatica L. 272

fleuryana Tardieu 272

odorata (Griff.) Symington 272

tonkinensis A. Chev. 272

Verbenaceae 343

Wrightia R.Br. 235

annamensis Eberh. \& Dubard 235

pubescens R.Br. 235

tomentosa Roem. \& Schult. var. cochinchinensis Pierre ex Pit. 235

Xylia Benth. 309

dolabriformis Benth. 309

kerrii Craib \& Hutch. 309

xylocarpa (Roxb.) Taub. var. kerrii (Craib \& Hutch.) I.C. Nielsen 309

Xylopia L. 232

vielana Pierre 232 